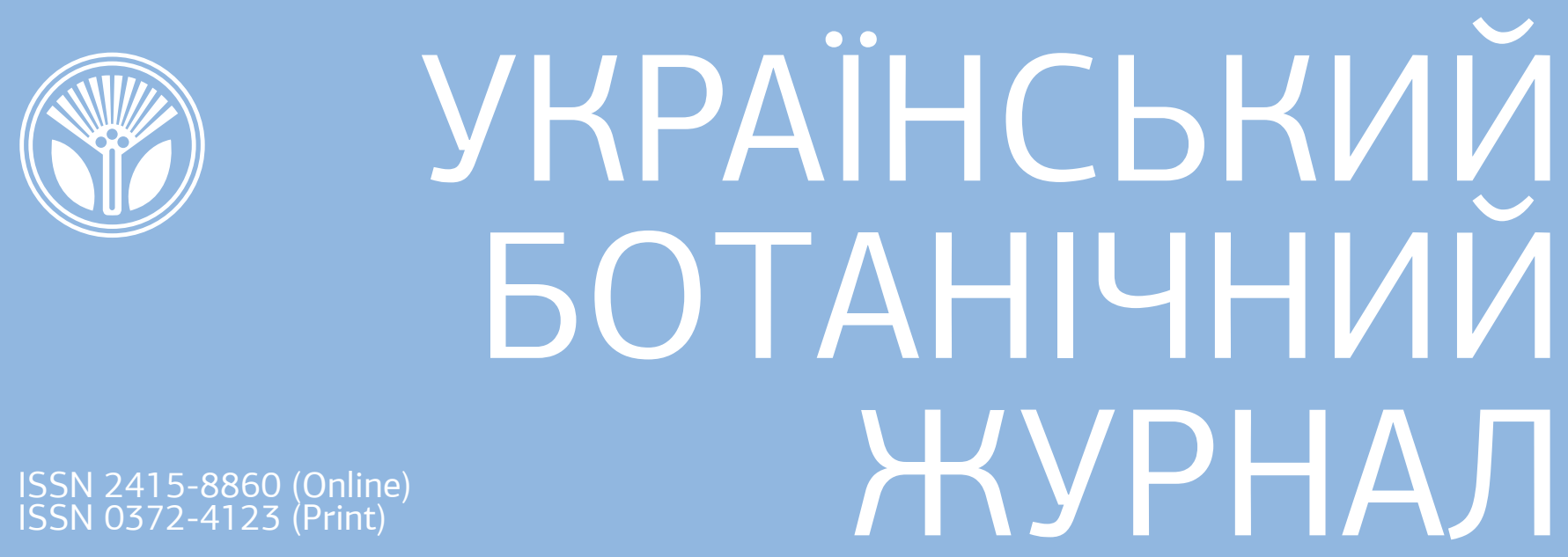

\title{
UKRAINIAN BOTANICAL JOURNAL
}

An international journal for botany \& mycology 
"Український ботанічний журнал" публікує статті з усіх напрямів ботаніки та мікології, в тому числі із загальних питань, систематики, флористики, геоботаніки, екології, еволюційної біології, географії, історії флори та рослинності, а також морфології, анатомії, фізіології, біохімії, клітинної та молекулярної біології рослин і грибів. Статті, повідомлення та інші матеріали публікуються в таких основних розділах: "Загальні проблеми, огляди та дискусії", "Систематика, флористика, географія рослин", "Гриби і грибоподібні організми", "Геоботаніка, екологія, охорона рослинного світу", "Червона книга України", "Флористичні знахідки", "Мікологічні знахідки", "Структурна ботаніка", "Фізіологія, біохімія, клітинна та молекулярна біологія рослин", "Гербарна справа", "Історія науки", "Хроніка", "Ювілейні дати", "Втрати науки", "Рецензії та новини літератури".

Статті друкуються українською, англійською та російською мовами

Ukrainian Botanical Journal is a scientific journal publishing articles and contributions on all aspects of botany and mycology, including general issues, taxonomy, floristics, vegetation science, ecology, evolutionary biology, geography, history of flora and vegetation as well as morphology, anatomy, physiology, biochemistry, cell and molecular biology of plants and fungi. Original articles, short communications and other contributions are published in sections "General Issues, Reviews and Discussions", "Plant Taxonomy, Geography and Floristics", "Fungi and Fungi-like Organisms", "Vegetation Science, Ecology, Conservation", "Red Data Book of Ukraine", "Floristic Records", "Mycological Records", "Structural Botany", "Plant Physiology, Biochemistry, Cell Biology and Molecular Biology", "Herbarium Curation", "History of Science", "News and Views", "Anniversary Dates", "In Memoriam", "Reviews and Notices of Publications".

Publication languages: Ukrainian, English and Russian

\section{РЕДАКЦІЙНА КОЛЕГІЯ}

Головний редактор - Сергій Л. МОСЯКІН

Заступники головного редактора - Ганна В. БОЙКО, Віра П. ГАЙОВА

Раїса І. БУРДА, Соломон П. ВАССЕР, Філіп ВЕРЛООВ (Бельгія), ВасиЛь П. ГЕЛЮТА, Зігмантас ГУДЖИНСКАС (Литва), Яків П. ДІДУХ,

Дмитро В. ДУБИНА, Олена К. ЗОЛОТАРЬОВА,

Сергій Я. КОНДРАТЮК, Елізавета Л. КОРДЮМ, Ірина А. КОРОТЧЕНКО, Ірина В. КОСАКІВСЬКА, Кароль МАРГОЛЬД (Словаччина), Евіатар НЕВО (Ізраїль), Віктор І. ПАРФЬОНОВ (Білорусь), Пітер РЕЙВЕН (США), Марина М. СУХОМЛИН, СусумУ ТАКАМАЦУ (Японія), Микола М. ФЕДОРОНЧУК, Олександр Є. ХОДОСОВЦЕВ, Петро М. ЦАРЕНКО, ІЛЛЯ І. ЧОРНЕЙ, Мирослав В. ШЕВЕРА, Юрій Р. ШЕЛЯГ-СОСОНКО, Наталія М. ШИЯН, Богдан ЯЦКОВЯК (Польща) Відповідальний секретар Марія Д. АЛЕЙНІКОВА

\section{EDITORIAL BOARD}

Editor-in-Chief - Sergiy L. MOSYAKIN

Associate Editors - Ganna V. BOIKO Vera P. HAYOVA

Raisa I. BURDA, Illya I. CHORNEY, Yakiv P. DIDUKH, Dmytro V. DUBYNA, Mykola M. FEDORONCHUK, Zigmantas GUDŽINSKAS (Lithuania), Vasyl P. HELUTA, Bogdan JACKOWIAK (Poland), Olexander E. KHODOSOVTSEV, Sergei Y. KONDRATYUK, Elisaveta L. KORDYUM, Iryna A. KOROTCHENKO, Iryna V. KOSAKIVSKA, Karol MARHOLD (Slovakia), Eviatar NEVO (Israel), Victor I. PARFENOV (Belarus), Peter RAVEN (USA), Yuriy R. SHELYAG-SOSONKO, Myroslav V. SHEVERA, Natalia M. SHYIAN, Maryna M. SUKHOMLYN, Susumu TAKAMATSU (Japan), Petro M. TSARENKO, Filip VERLOOVE (Belgium), Solomon P. WASSER, Olena K. ZOLOTAREVA

Editorial Assistant - Mariya D. ALEINIKOVA

На першій сторінці обкладинки: Sarcoscypha coccinea.Національний природний парк "Голосіївський" Фото Марії Зикової

Front page: Sarcoscypha coccinea. Holosiiv National Nature Park Photo by Mariya Zykova

Редакція "Українського ботанічного журналу"

Інститут ботаніки НАН України вул. Терещенківська, 2, Київ 01004, Україна
(044) 235-41-82 secretary_ubzh@ukr.net https://ukrbotj.co.ua 


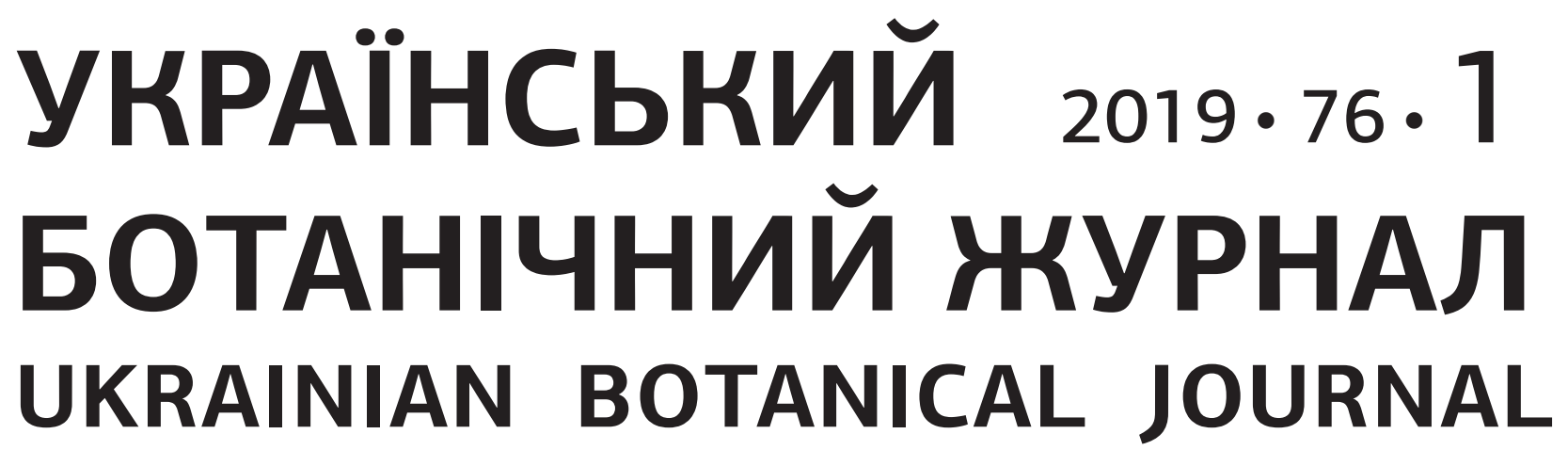

НАУКОВИЙ ЖУРНАЛ • ЗАСНОВАНИЙ 1921 р. • SCIENTIFIC JOURNAL • PUBLISHED SINCE 1921

\section{M I C T}

\section{Систематика, флористика, географія рослин}

Мосякін С.Л., Бойко Г.В., Глухова С.А. Artemisia verlotiorum (Asteraceae) у континентальній частині Україні: тепер

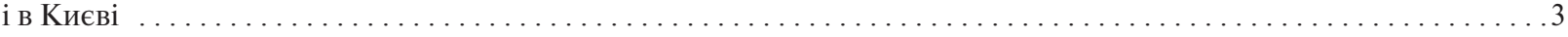

Цимбалюк 3.М., Безусько Л.Г., Мосякін С.Л., Ниценко Л.М. Паліноморфологія видів роду Dipsacus (Dipsacaceae) флори України: значення для цілей систематики та спорово-пилкового аналізу $\ldots \ldots \ldots \ldots \ldots \ldots \ldots \ldots$

\section{Гриби і грибоподібні організми}

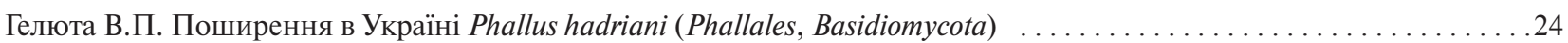

Геоботаніка, екологія, охорона рослинного світу

Єременко Н.С. Сингенетичні зміни рудеральної рослинності Кривого Рогу $\ldots \ldots \ldots \ldots \ldots \ldots \ldots \ldots \ldots \ldots \ldots \ldots \ldots$

Шевчик В.Л., Шевчик Т.В. Фітоценотична характеристика угруповань із участю Amorpha fruticosa (Fabaceae) у

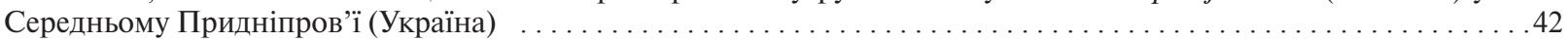

\section{Червона книга Украӥни}

Мойсієнко І.І., Данилик І.М., Мельник Р.П., Садова О.Ф., Захарова М.Я. Schoenoplectiella mucronata (Cyperaceae)

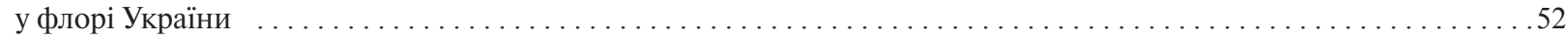

\section{Флористичні знахідки}

Пахшвьоль К., Пахшвьоль Т. Нова знахідка Arabidopsis neglecta (Brassicaceae) на території масиву Свидовець

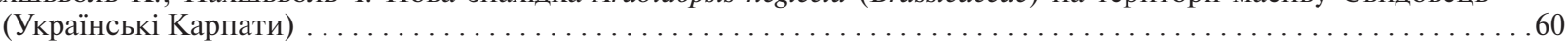

Гусейнова А.Й., Агаєва Р.Н., Гарахані Р.Х., Алі-заде В.М. Serratula coronata (Asteraceae) - новий вид для флори

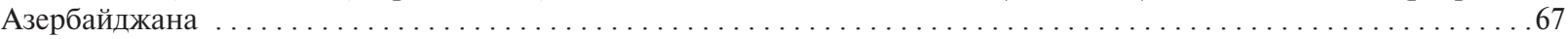

Фізіологія, біохімія, клітинна та молекулярна біологія рослин

Аль-Маалі Г.А., Веденичова Н.П., Бісько Н.А., Косаківська І.В. Вплив мікроелементів на вміст цитокінінів у міцеліальній біомасі лікарського гриба Trametes versicolor (Polyporaceae, Basidiomycota) $\ldots \ldots \ldots \ldots \ldots \ldots .71$

\section{Хроніка}

Зав'ялова Л.В., Сенчило О.О., Коломійчук В.П., Кучер О.О. Вшанування пам'яті Антонія Анджейовського . . . . .79 Гамор Ф. Міжнародна науково-практична конференція: "Проблеми збереження гірських екосистем та сталого використання біологічних ресурсів Карпат" (до 50-річчя створення Карпатського біосферного заповідника) . . .81

(с ІНСТИТУТ БОТАНІКИ ім. М.Г. ХОЛОДНОГО НАН УКРАЇНИ, 2019 


\section{Рецензії та новини літератури}

Протопопова В.В., Устименко П.М. Рецензія на книгу: Васильева Т.В., Эннан А.А.-А., Шихалеева Г.Н. Сосудистые

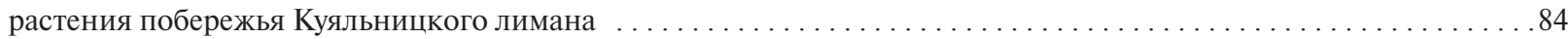

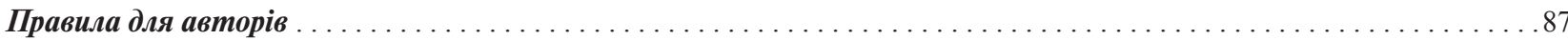

\section{CONTENTS}

\section{Plant Taxonomy, Geography and Floristics}

Mosyakin S.L., Boiko G.V., Glukhova S.A. Artemisia verlotiorum (Asteraceae) in the continental part of Ukraine:

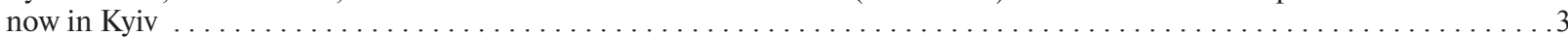

Tsymbalyuk Z.M., Bezusko L.G., Mosyakin S.L., Nitsenko L.M. Pollen morphology of species of Dipsacus (Dipsacaceae) in the flora of Ukraine: significance for taxonomy and spore-pollen analysis $\ldots \ldots \ldots \ldots \ldots \ldots \ldots \ldots \ldots \ldots \ldots$

\section{Fungi and Fingi-like Organisms}

Heluta V.P. Distribution of Phallus hadriani (Phallales, Basidiomycota) in Ukraine ....................... 24

\section{Vegetation Science, Ecology, Conservation}

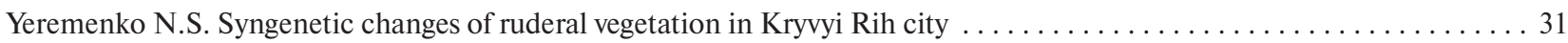
Shevchyk V.L., Shevchyk T.V. Phytocenotic characteristics of plant communities with Amorpha fruticosa (Fabaceae) in the Middle Dnipro area (Ukraine)

\section{Red Data Book of Ukraine}

Moysiyenko I.I., Danylyk I.M., Melnyk R.P., Sadova O.F., Zakharova M.Ya. Schoenoplectiella mucronata (Cyperaceae) in

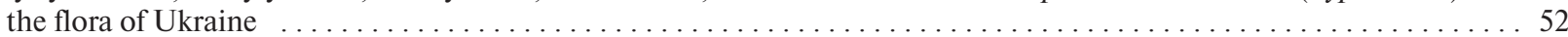

\section{Floristic Records}

Pachschwöll C., Pachschwöll T. A new find of Arabidopsis neglecta (Brassicaceae) in the Svydovets Massif (Ukrainian

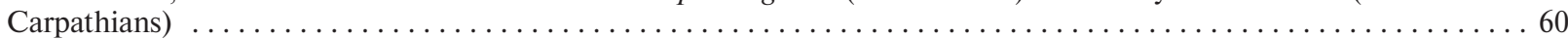

Huseynova A.Y., Aghayeva P.N., Qarakhani P.Kh., Ali-zade V.M. Serratula coronata (Asteraceae) - a new species record

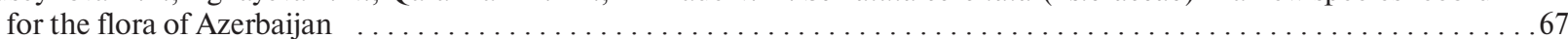

\section{Plant Physiology, Biochemistry, Cell Biology and Molecular Biology}

Al-Maali G.A., Vedenicheva N.P., Bisko N.A., Kosakivska I.V. Effect of microelements on cytokinins content in mycelial biomass of medicinal mushroom Trametes versicolor (Polyporaceae, Basidiomycota) $\ldots \ldots \ldots \ldots \ldots \ldots \ldots \ldots \ldots$

\section{News and Views}

Zavialova L.V., Senchylo O.O., Vitaliy P. Kolomiychuk V.P., Kucher O.O. Commemoration of Antoni Andrzejowski .. . . 79

Hamor F. International Scientific Conference "Issues of conservation of mountain ecosystems and sustainable use of biological resources of the Carpathians" (dedicated to the $50^{\text {th }}$ anniversary of the establishment of the Carpathian

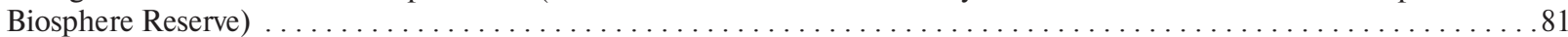

\section{Reviews and Notices of Publications}

Protopopova V.V., Ustymenko P.M. Review of the book: Vasilyeva T.V., Ennan A.A.-A., Shykhaleyeva G.N. Vascular

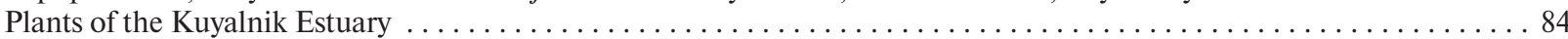


https://doi.org/10.15407/ukrbotj76.01.003

\title{
Artemisia verlotiorum (Asteraceae) in the continental part of Ukraine: now in Kyiv
}

\author{
Sergei L. MOSYAKIN ${ }^{1}$, Ganna V. BOIKO ${ }^{1}$, Svitlana A. GLUKHOVA² \\ ${ }^{1}$ M.G. Kholodny Institute of Botany, National Academy of Sciences of Ukraine \\ 2 Tereschenkivska Str., Kyiv 01004, Ukraine \\ s_mosyakin@hotmail.com \\ bav22@ukr.net \\ ${ }^{2}$ Syrets Arboretum \\ 43 Tyraspolska Str., Kyiv 04136, Ukraine \\ syrets.dendropark@gmail.com
}

Mosyakin S.L., Boiko G.V., Glukhova S.A. 2019. Artemisia verlotiorum (Asteraceae) in the continental part of Ukraine: now in Kyiv. Ukrainian Botanical Journal, 76(1): 3-8.

Abstract. Colonies of Artemisia verlotiorum (Asteraceae), an alien species of East Asian origin now widespread in many countries of the world, were found in 2018 in Kyiv in the Syrets Arboretum (Syretskiy Dendropark) and in a nearby abandoned plant nursery and greenhouses. At present, three clonal colonies have been revealed. Most probably rhizomes of that species were initially introduced to Kyiv with soil and/or imported trees and/or shrubs. However, one colony (along the wall of the administrative building of the arboretum) most probably emerged from seeds dispersed by wind from the main (supposedly initial) colony in the abandoned nursery. Before our find in Kyiv, A. verlotiorum was reliably known in Ukraine in Crimea (reported since the 1920s), Transcarpathia, and from Lviv (recent records, to be discussed in detail in a forthcoming article). Most probably A. verlotiorum is spreading in Eastern Europe mainly by rhizome fragments with soil and plant material. Other alien taxa of the Artemisia vulgaris group (especially $A$. umbrosa and $A$. argyi) occur in Ukraine mainly as "railroad" plants.

Keywords: alien species, Artemisia verlotiorum, Asteraceae, Ukraine

Мосякін С.Л. ${ }^{1}$, Бойко Г.В. ${ }^{1}$, Глухова С.А. ${ }^{2}$ 2019. Artemisia verlotiorum (Asteraceae) у континентальній частині Україні: тепер і в Києві. Український ботанічний журнал, 76(1): 3-8.

${ }^{1}$ Інститут ботаніки ім. М.Г. Холодного НАН України

вул. Терещенківська 2, Київ 01004, Україна

${ }^{2}$ Сирецький дендропарк

вул. Тираспольська 43, Київ 04136, Україна

Реферат. Колонії Artemisia verlotiorum (Asteraceae), виду східноазійського походження, нині натуралізованого у багатьох країнах світу, були знайдені у 2018 році в Києві у Сирецькому дендропарку, а також неподалік нього на території покинутого розплідника рослин і біля теплиць. Виявлені три клональні колонії. Найімовірніше кореневища рослин цього виду спочатку були завезені у Київ з грунтом або імпортованими деревами та кущами. Однак одна колонія (уздовж стіни адміністративної будівлі дендропарку), вірогідно, виникла 3 насіння, занесеного вітром 3 головної (ймовірно первинної) колонії у розпліднику. До нашої знахідки у Києві вид A. verlotiorum був достовірно відомий в Україні з Криму (наводився з 1920-х рр.), Закарпаття та Львова (дані детальніше обговорюватимуться у наступній статті). Найбільш ймовірно, що A. verlotiorum поширюється у Східній Европі переважно фрагментами кореневищ та/ або столонів з грунтом і рослинним матеріалом. Інші адвентивні види групи Artemisia vulgaris (особливо A. umbrosa і A. argyi) трапляються в Україні переважно як "залізничні" рослини.

Ключові слова: чужорідні види, Україна, Artemisia verlotiorum, Asteraceae

\section{Introduction}

Artemisia verlotiorum Lamotte (Asteraceae), a species described from Europe (see Verlot, 1875, 1876; Lamotte, 1877) but native to East Asia (China), is currently known as an alien and/or invasive species naturalized in many

(C) S.L. MOSYAKIN, G.V. BOIKO, S.A. GLUKHOVA, 2019

Український ботанічний журнал, 2019, 76(1) regions of Europe, North and South Africa, western Asia, South America, Australia, and New Zealand (Pampanini, 1923, 1933; Brenan, 1950; Bangerter, 1978; Esler, 1987; Webb et al., 1988; Leonova, 1994; Ariza Espinar, 1997; Thompson, 2007; Ling et al., 2011; Verloove, 2013-onward; Kurşat, Civelek, 2011; Mosyakin et al., 2018, and references therein). It is 
also definitely present in North America (Mosyakin, unpublished data and an article in preparation), where its cryptic invasion was totally overlooked until recently because of its confusion with Eurasian $A$. vulgaris L. s. str. (also introduced in North America), and probably also with some native North American taxa of the A. vulgaris group (Aretmisia sect. Artemisia).

In our earlier articles (Mosyakin, 1990, 1991, 1992, 2006; Dubovik, Mosyakin, 1991; Boiko, 2009, 2012, 2013; Mosyakin et al., 2017, 2018) we already discussed various issues of distribution, morphology, taxonomy and nomenclature of Artemisia verlotiorum, A. umbrosa (Turcz. ex Besser) Turcz. ex Verlot and some other alien species of the $A$. vulgaris species aggregate occurring in Ukraine and other countries of Eastern Europe, in particular, Russia, Belarus, Lithuania, Latvia, etc.

As we already commented (Mosyakin, 1990, 2006; Mosyakin et al., 2018), many earlier records of "A. verlotiorum" from Eastern Europe in fact belong to other related species of the A. vulgaris aggregate, especially $A$. umbrosa and sometimes $A$. argyi H.Lév. $\&$ Vaniot (see discussion and references in Mosyakin et al., 2018).

The specimens of $A$. verlotiorum collected in Kyiv in 2018 (see below) are deposited in the National Herbarium of Ukraine (KW). Herbarium acronyms mentioned in the article follow Thiers (2008-onward).

\section{Earlier records of Artemisia verlotiorum in the territory of Ukraine}

The first known occurrence of $A$. verlotiorum in Ukraine, and in Eastern Europe in general, was reported by Gams (1929) in the 1920s, who mentioned, although with some doubt, that he observed this species as a weed in the Nikita Botanical Garden: "... der Bearbeiter (Gams) konnte sie hier nur im Garten von Nikita auf der Krim als Unkraut feststellen" (Gams, 1929: 631). However, that record was neglected and the species has not been reported in floras and other publications covering the territory of Crimea. This record was confirmed later, first based on observations by Dubovik (see Mosyakin, 1990; Dubovik, Mosyakin, 1991) and then by Mosyakin (2006), who indicated the continued presence of A. verlotiorum in Nikita (Yalta area) in and near the Nikita Botanical Garden. Our analysis (by Boiko) of herbarium specimens of the Nikita Botanical Garden National Science Center (YALT) demonstrated that the species was often collected in this area for many years, but it was misidentified as A. vulgaris (see Boiko, 2009). Special surveys (by Mosyakin and Boiko, before 2014) also demonstrated that $A$. verlotiorum is now widespread in the Crimean South Coast. In particular, we registered this species in Yalta, Gurzuf, Partenit, Koreiz, where in some localities the plants formed dense and large stands (Mosyakin, 2006; Boiko, 2009). At present the species should be considered as fully naturalized in Crimea (at least in the South Coast area).

Artemisia umbrosa (also known under misapplied names "A. codonocephala" auct. non Diels, "A. dubia" auct. non Wall. ex Besser, and "A. lavandulifolia" auct. non DC.; see Mosyakin et al., 2018) is also reported in Crimea (Yena, 2005, 2012; Seregin at al., 2015), but it seems to be much rarer there than $A$. verlotiorum s. str. However, at least some (or most probably all?) records of "A. dubia" by Seregin et al. (2015) in fact belong to A. verlotiorum s. str.; in particular, the following specimens from MW: MW0628959, MW0628960, MW0628961, MW0628962 (images available from Moscow Digital Herbarium: Seregin, 2019). These specimens from Sevastopol and Balaklava correspond to records in the article by Seregin et al. (2015) and because of that the occurrence of $A$. umbrosa ("A. dubia" sensu auct.) in that area is in need of confirmation.

Cultivation of $A$. verlotiorum by Boiko in the Donetsk Botanical Garden of the National Academy of Sciences of Ukraine in 2005-2014 demonstrated that the plants in this region normally develop numerous vegetative shoots and under favorable conditions reach the flowering and fruiting stages. Because of that it has been suggested that further dispersal of the species in the continental part of Ukraine is quite possible (Boiko, 2009).

Probably the first mention of $A$. verlotiorum for the continental part of Ukraine was made in the editorial note to the article by Boiko (2009: 834): "A. verlotiorum також знайдена, за даними В.В. Протопопової, в м. Ужгороді в палісаднику біля вокзалу; в Чернівецькій обл. поряд із залізницею, поблизу кордону" ("A. verlotiorum was also found, according to V.V. Protopopova, in Uzhgorod in a flower bed [or small garden] near the railway station; in Chernivtsi Region near the railway not far from the [state] border"). That note was added in proof by the editorial team of the Ukrainian Botanical Journal following the personal communication of Prof. Vera V. Protopopova based on observations by and specimens of Protopopova and Myroslav V. Shevera (both from the M.G. Kholodny Institute of Botany). The studied specimens from Transcarpathian Region deposited in $\mathrm{KW}$ evidently belong to $A$. verlotiorum s. str.; however, $A$. umbrosa was also recently found in Transcarpathia by Shevera (personal communication; 

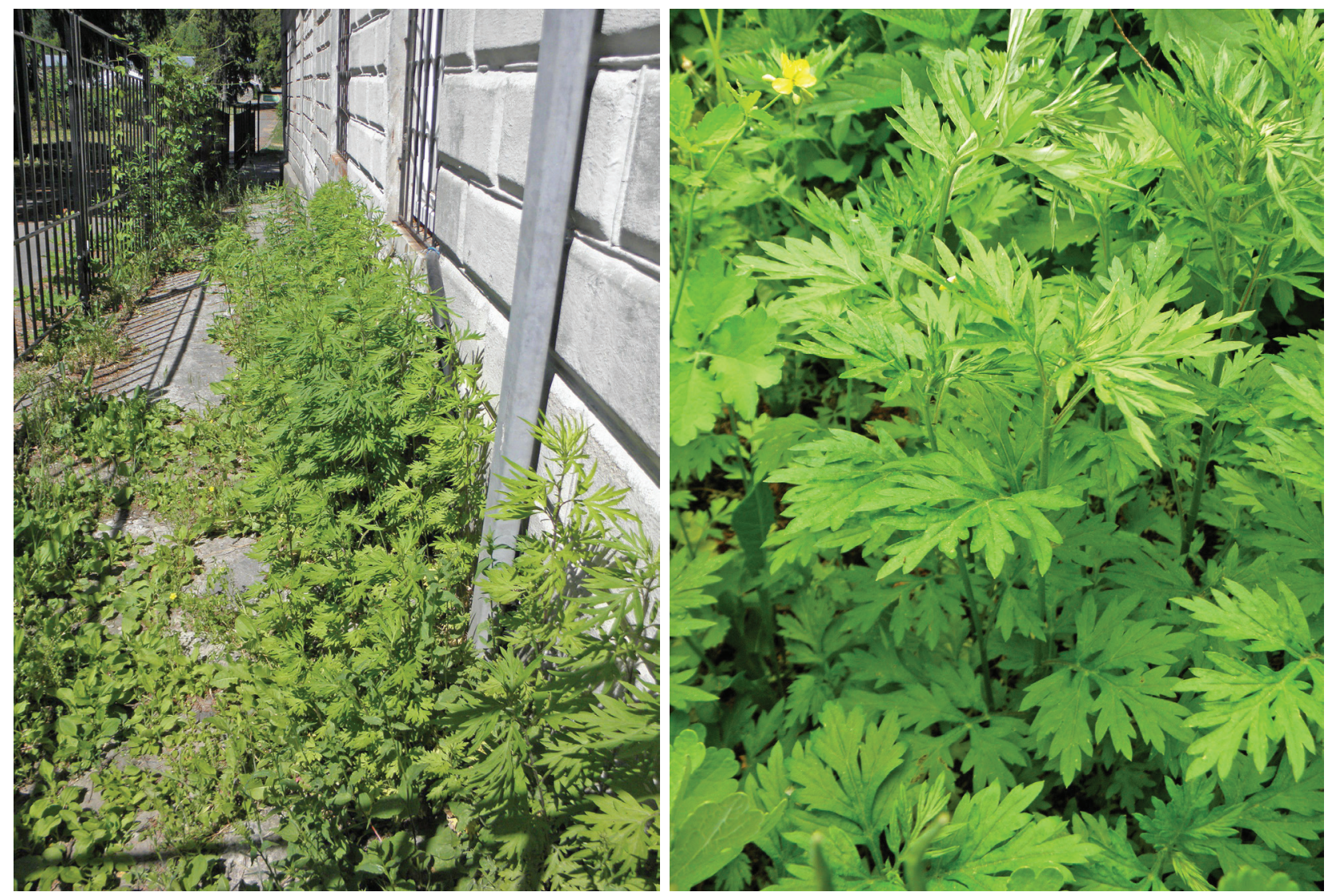

Fig. 1. Artemisia verlotiorum along the wall of the administrative building (left) and in a lilac garden (right, young shoots), Syrets Arboretum, Kyiv (May 2018, all photographs by S. Mosyakin).

Boiko et al., article in preparation). In our opinion, the specimens from Chernivtsi Region available in KW belong to $A$. umbrosa and because of that the presence of A. verlotiorum s. str. in that region cannot be confirmed yet. However, considering the occurrence of the latter in adjacent countries of Eastern Central Europe, finds of A. verlotiorum in Chernivtsi Region cannot be excluded in the future. In addition to that, A. verlotiorum s. str. is now also reported from Lviv (Mamchur et al., 2017), which is also confirmed by some specimens deposited in KW. However, the morphologically similar species A. umbrosa is also known in Lviv Region (Kuzyarin, 2012) and because of that critical revision of specimens and records of $A$. verlotiorum and $A$. umbrosa from the western part of Ukraine is needed, and will be provided in a forthcoming article (Boiko et al., in preparation).

\section{Artemisia verlotiorum in Kyiv}

A colony of A. verlotiorum was discovered in Kyiv by Mosyakin on 12 May 2018. The plants were growing in shady places in a lilac garden (syringarium) not

far from the entrance of the Syrets Arboretum (Syretskiy Dendropark, Сирецький дендропарк) in the northwestern part of the city. This species was not mentioned in the recent checklists of plants of the arboretum (Glukhova et al., 2016; Shynder et al., 2018).

Another clonal stand of $A$. verlotiorum was found on 28 May 2018 along the back wall of the administrative building of the arboretum (Fig. 1), where plants were growing in the cracks of asphalt (tarmac) and between the asphalt surface and the brick wall. Growing conditions of this colony suggested that it emerged not from rhizomes/stolons or rhizome fragments but from seeds brought by wind from some other nearby colony. Special surveys in the territory of a nearby abandoned plant nursery revealed a larger colony near destroyed greenhouses and along the road (Fig. 2,3). Most probably that colony was the source of seeds that produced the two smaller colonies in the Syrets Arboretum, especially the stands along the wall (see above).

Our observations in August-October of 2018 confirmed that in climatic conditions of Kyiv (as

Український ботанічний журнал, 2019, 76(1) 


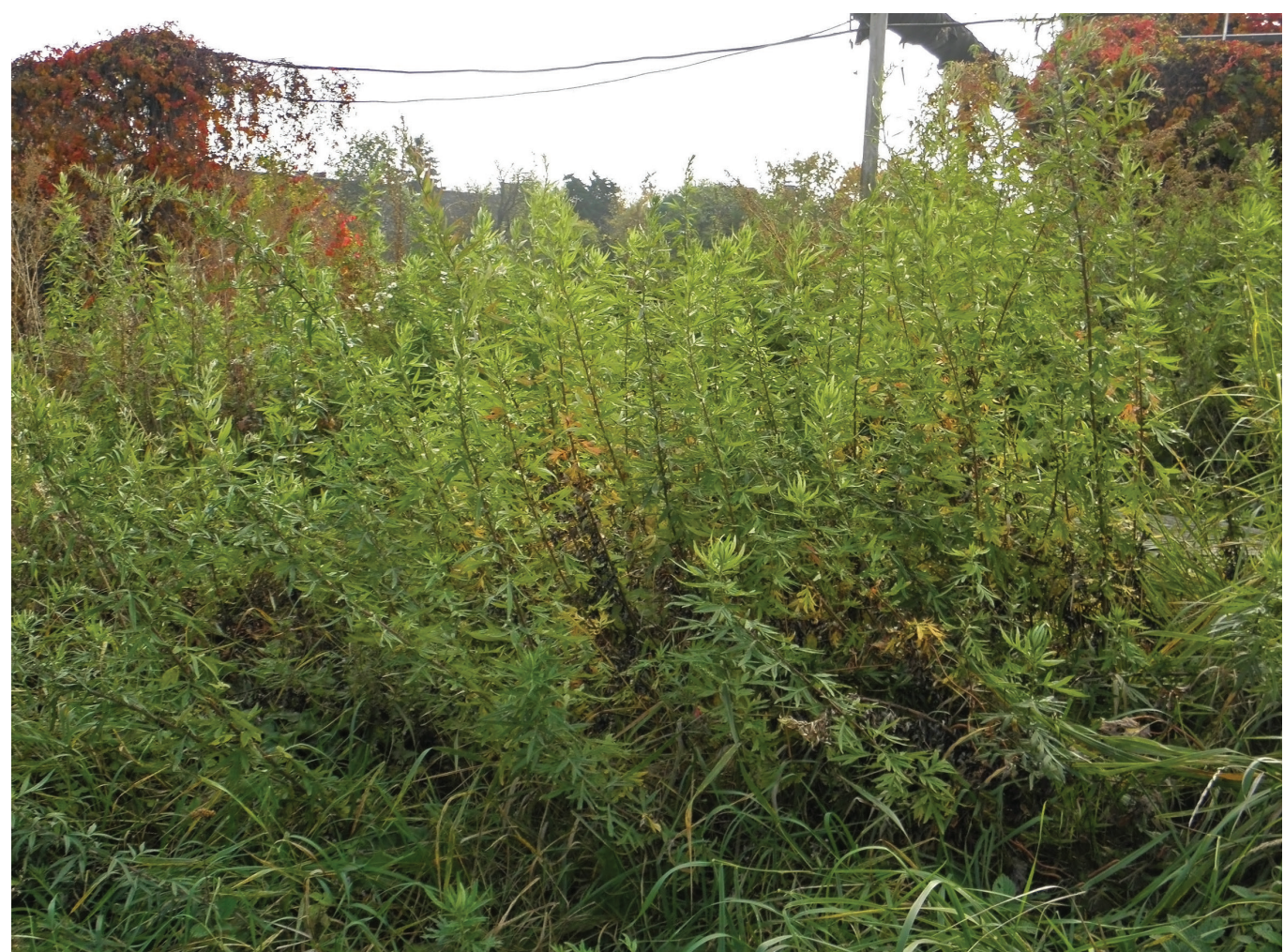

Fig. 2. Dense stands of Artemisia verlotiorum in an abandoned plant nursery near the Syrets Arboretum, Kyiv (October 2018)
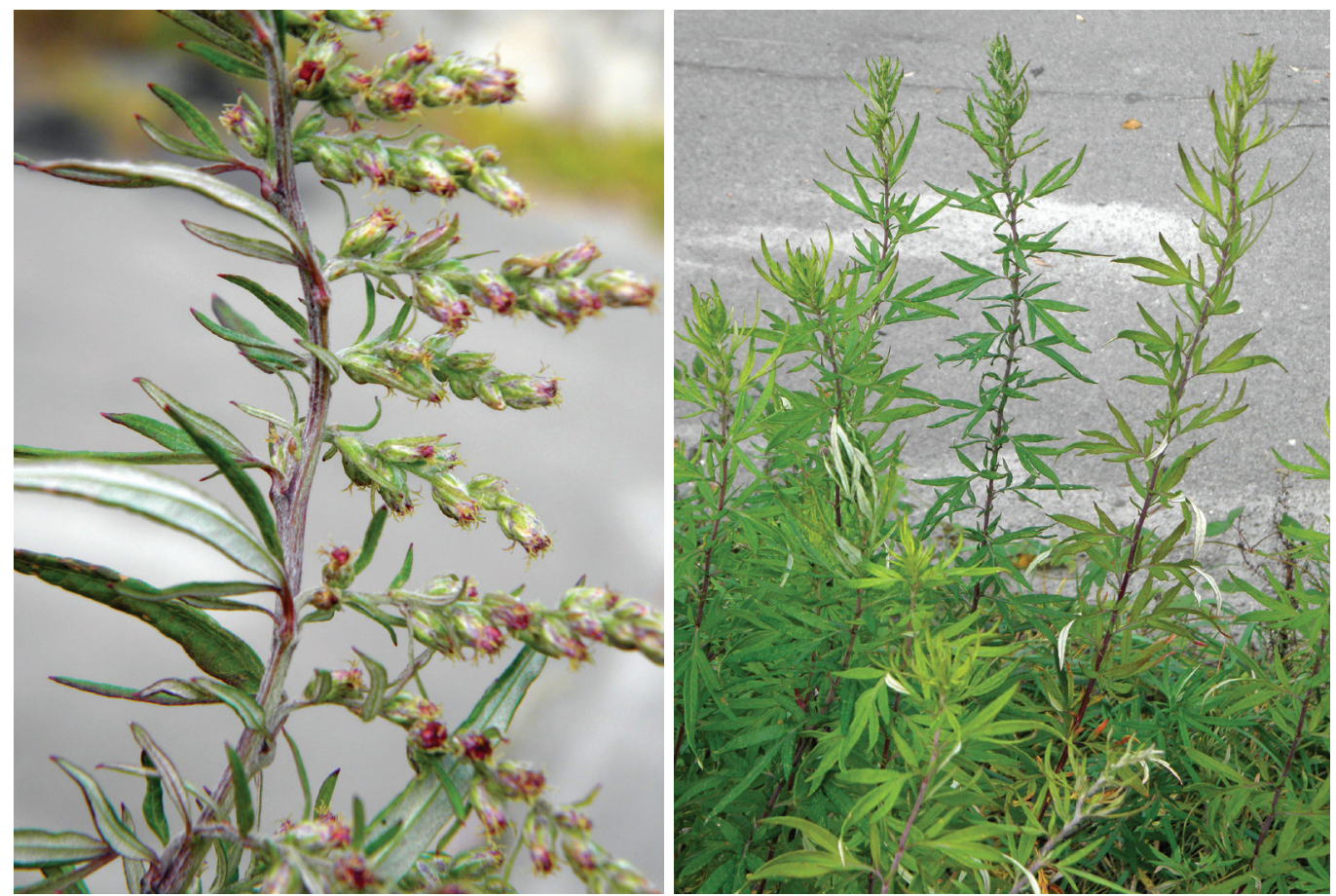

Fig. 3. Artemisia verlotiorum growing along the road in an abandoned plant nursery near the Syrets Arboretum, Kyiv (October, 2018) 
well as elsewhere within its native and introduced range) $A$. verlotiorum is a very late-flowering species, especially if compared to $A$. vulgaris s. str. The shoots of $A$. verlotiorum were rather well developed already in mid-May (see Fig. 1); however, first inflorescences were observed in the Syrets Arboretum in late August, and only in October the plants started to produce seeds. At that time the plants of $A$. vulgaris growing nearby were fully developed and already abundantly produced ripe seeds since mid-summer.

The plants were growing in ruderal plant communities together with the following common associated species: Artemisia vulgaris, Ballota nigra L. aggr. (incl. B. ruderalis Sw.), Elytrigia repens (L.) Nevsky (Elymus repens (L.) Gould), Erigeron canadensis L. (Conyza canadensis (L.) Cronquist), Humulus lupulus L., Parthenocissus inserta (A.Kern.) Fritsch, Solidago canadensis L., Urtica dioica L., with lesser participation of Atriplex sagittata Borkh., Chelidonium majus L., Chenopodium album L. aggr., C. betaceum Andrz. (C. strictum auct. non Roth), Fallopia convolvulus (L.) Á.Löve, Lactuca serriola L., Oenotera biennis L. aggr., etc.

\section{Concluding remarks}

The actual distribution patterns of Artemisia verlotiorum in Eastern Europe are obscured by earlier misidentifications because that species is morphologically similar to and so easily confused with other taxa of the $A$. vulgaris aggregate, especially $A$. umbrosa. As we discussed above, there were also some cases of misidentification of Ukrainian specimens from the continental and peninsular (Crimea) parts of the country.

We expect that $A$. verlotiorum s. str. will be found in the future in some other regions of Ukraine, especially in parks, botanical gardens, and other similar habitats to which the rhizomes of this species can be brought with soil or plant material. However, occurrence and dispersal of $A$. verlotiorum along railroads, roads, river valleys, etc., is also possible.

\section{Acknowledgments}

We are grateful to Vera V. Protopopova and Myroslav V. Shevera (M.G. Kholodny Institute of Botany, NAS of Ukraine) for providing information on the occurrence of A. verlotiorum in the Transcarpathian Region and Lviv, to Zvenislava I. Mamchur and Maria V. Chuba (Ivan Franko National University of Lviv) for providing images of plants from Lviv, and to Filip Verloove (Botanic Garden Meise, Belgium) and Peter J. de Lange (Environment and Animal Sciences, UniTec Institute of Technology, Auckland, New Zealand) for their useful comments on the manuscript.

\section{REFERENCES}

Ariza Espinar L. 1997. Anthemideae. In: Flora fanerogámica Argentina. Fasc. 46: Asteraceae, pt. 7. Córdoba, Argentina: Programa ProFlora (CONICET), 33 pp.

Bangerter E.B. 1978. New and interesting records of adventive plants from the Auckland Institute and Museum Herbarium. Records of the Auckland Institute and Museum, 15: 27-35.

Boiko G.V. 2009. New data on alien species of the genus Artemisia L. (Asteraceae) in the Ukrainian flora. Ukrainian Botanical Journal. 66(6): 833-835. [Бойко Г.В. 2009. Нові відомості щодо адвентивних видів з роду Artemisia L. (Asteraceae) флори України. Український ботанічний журнал, 66(6): 833-835].

Boiko A.V. [G.V.]. 2012. Artemisia umbrosa (Turcz. ex Besser) Pamp., an alien species in the flora of Ukraine. In: Problemy izucheniya adventivnoy i sinantropnoy flor Rossii $i$ stran blizhnego zarubezhya: 4 Mezhdunarodnaya konferentsiya (Izhevsk, 4-7 Dec. 2012 g.). Eds O.G. Baranova, A.N. Puzyrev. Izhevsk, pp. 27-29. [Бойко А.B. 2012. Artemisia umbrosa (Turcz. ex Besser) Pamp. - адвентивный вид флоры Украины. В сб.: Проблемы изучения адвентивной и синантропной флор России и стран ближнего зарубежья: 4 международная конференция (Ижевск, 4-7 декабря 2012 г.). Ред. О.Г. Баранова, А.Н. Пузырев. Ижевск, с. 27-29].

Boiko G.V. 2013. Identification key for the species of the genus Artemisia L. (Asteraceae) of the flora of Ukraine. Ukrainian Botanical Journal, 70(4): 479-482. [Бойко Г.В. 2013. Ключ для визначення видів роду Artemisia L. (Asteraceae) флори України. Український ботанічний журнал, 70(4): 479-482].

Brenan J.P.M. 1950. Artemisia verlotorum Lamotte and its occurrence in Britain. Watsonia, 1(4): 209-223.

Dubovik O.N., Mosyakin S.L. 1991. Artemisia verlotiorum (Asteraceae) - a new adventive species of the North Caucasus flora. Botanicheskii Zhurnal, 76(10): 14081411. [Дубовик О.Н., Мосякин С.Л. 1991. Artemisia verlotiorum (Asteraceae) - новый адвентивный вид флоры Северного Кавказа. Ботанический журнал, 76(10): 1408-1411].

Esler A.E. 1987. The naturalisation of plants in urban Auckland, New Zealand 3. Catalogue of naturalised species. New Zealand Journal of Botany, 25: 539-558. https://doi.org/10.1080/0028825X.1987.10410085

Gams H. 1929. Artemisia. In: Hegi G. Illustrierte Flora von Mitteleuropa, Bd 6, Hf 2. München: Verlag J.F. Lehmann, S. 626-672.

Glukhova S.A., Shynder O.I., Yemets L.I., Mykhaylyk S.M. 2016. Catalogue of herbaceous plants of the Syretskiy Arboretum. Poltava: Poltavskiy Literator, 82 pр. [Глухова С.А., Шиндер О.І., Ємець Л.І., Михайлик С.М. 2016. Каталог трав'янистих рослин Сирецького дендрологічного парку. Полтава: Полтавський літератор, $82 \mathrm{c.}$.].

Kurşat M., Civelek Ş. 2011. Artemisia vulgaris L. ve Artemisia verlotiorum Lamotte (Asteraceae) Türlerinin Morfolojik Bakımından Araștırılması (Morphological investigation of Artemisia vulgaris L. and Artemisia verlotiorum 
Lamotte species). Firat Üniversites Fen Bilimleri Dergisi, 23(2): 125-132.

Kuzyarin O.T. 2012. Alien species of vascular plants new for Lviv Region. Naukovi Zapysky Derzhavnogo Pryrodoznavchogo Миzеуu (Lviv), 28: 143-144. [Кузярін О.Т. 2012. Нові адвентивні види судинних рослин для Львівської області. Наукові записки Державного природознавчого музею (Львів), 28: 143-144].

Lamotte M. 1877. Recherches sur une nouvelle espèce du genre Artemisia. Compte-Rendu de l'Association Française pour l'Avancement des Sciences, Paris (Compte-Rendu de la $5^{\mathrm{me}}$ Session. Clermont-Ferrand, 1876), 5: 511-513.

Leonova T.G. 1994. Artemisia. In: Flora Partis Europaeae URSS, vol. 7. Ed. N.N. Tzvelev. Leningrad: Nauka, pp. 150-174. [Леонова Т.Г. 1994. Artemisia. В кн.: Флора европейской части СССР, т. 7. Ред. Н.Н. Цвелев. Ленинград: Наука, с. 150-174].

Ling Y.-R., Humphries C.J., Gilbert M.G. 2011. Artemisia. In: Flora of China, vol. 20-21. Eds Z.Y. Wu, P.H. Raven, D.Y. Hong. Beijing: Science Press \& St. Louis: Missouri Botanical Garden Press, pp. 676-737.

Mamchur Z., Chuba M., Drach Yu. 2017. Bryophytes and vascular plants in railway areas of the city of Lviv. Visnyk Lvivs'kogo Universytetu. Series Biology, 75: 54-65. [Мамчур 3., Чуба М., Драч Ю. 2017. Мохоподібні та судинні рослини на території залізниці міста Львова. Вісник Львівського університету. Серія біологічна, 75: 54-65].

Mosyakin S.L. 1990. New and noteworthy alien species of Artemisia L. (Asteraceae) in the Ukrainian SSR. Ukrainian Botanical Journal, 47(4): 10-13.

Mosyakin S.L. 1991. Preliminary list of recent additions to the alien flora of Ukraine. Ukrainian Botanical Journal, 48(4): 28-34.

Mosyakin S.L. 1992. Floristic notes on alien plants in Kiev. Ukrainian Botanical Journal, 49(6): 36-39. [Мосякін С.Л. 1992. Флористичні нотатки про адвентивні рослини м. Києва. Український ботанічний жжрннал, 49(6): 36-39].

Mosyakin S.L. 2006. On distribution of Artemisia verlotiorum Lamotte (Asteraceae) and related alien species in Ukraine. Chornomors'kyi Botanichnyi Zhurnal, 2(1): 93-97. [Мосякін С.Л. 2006. До поширення Artemisia verlotiorum Lamotte (Asteraceae) та споріднених адвентивних видів в Україні. Чорноморський ботанічний журнал, 2(1): 93-97].

Mosyakin S.L., Boiko G.V., Verloove F. 2017. Lectotypification of Artemisia mongolica $(=A$. vulgaris var. mongolica, Asteraceae). Phytotaxa, 297(3): 257-264. https://doi.org/10.11646/phytotaxa.297.3.4

Mosyakin S.L., Verloove F., Boiko G.V. 2018. The correct authorship and nomenclature of Artemisia umbrosa (Asteraceae), with comments on some misapplied names and distribution of the species in Eastern Europe. Ukrainian Botanical Journal, 75(3): 213-229. https://doi.org/10.15407/ukrbotj75.03.238

Pampanini R. 1923. Contributo alla conoscenza dell' Artemisia Verlotorum Lamotte. Bullettino della Società Botanica Italiana [vol. of 1923], 1-2: 76-90.
Pampanini R. 1933. Settimo ed ultimo contributo alla conoscenza dell' "Artemisia Verlotorum" Lamotte. Nuovo Giornale Botanico Italiano, n. s., 40(2): 183-224.

Seregin A.P. (Ed.). 2019. Moscow Digital Herbarium: Electronic resource. Moscow: Moscow State University. Available from: https://plant.depo.msu.ru (Accessed 02 February 2019).

Seregin A.P., Yevseyenkov P.E., Svirin S.A., Fateryga A.V. 2015. Second contribution to the vascular flora of the Sevastopol area (the Crimea). Wulfenia, 22: 33-82.

Shynder O.I., Glukhova S.A., Mykhaylyk S.M. 2018. Spontaneous flora of the Syrets Arboretum of the national importance (city of Kyiv). Introduktsiya Roslyn (Kyiv), 2: 54-63. [Шиндер O.I., Глухова С.А., Михайлик С.М. 2018. Спонтанна флора Сирецького дендрологічного парку загальнодержавного значення (м. Київ). Iнтродукція рослин (Київ), 2: 54-63].

Thiers B. 2008-onward (continuously updated). Index Herbariorum. A global directory of public herbaria and associated staff. New York Botanical Garden's Virtual Herbarium. Available from: http://sweetgum.nybg.org/ science/ih (Accessed 02 February 2019).

Thompson I.R. 2007. A taxonomic treatment of tribe Anthemideae (Asteraceae) in Australia. Muelleria, 25: 21-58.

Verloove F. 2013-onward. Not every Far Eastern mugwort is Artemisia verlotiorum! In: Verloove F. Manual of the Alien Plants of Belgium. Botanic Garden of Meise, Belgium. Available from: http://alienplantsbelgium.be/content/ not-every-far-eastern-mugwort-artemisia-verlotiorum (Accessed 02 February 2019).

Verlot J.-B. 1875. Catalogue des graines du Jardin botanique de Grenoble, 1875. Grenoble [non vidi].

Verlot J.-B. 1876. Artemisia umbrosa Turcz. [Note extraite du Catalogue des graines du Jardin botanique de Grenoble, 1875, par M. J.-B. Verlot]. P. 73 in: [Anonymous]. Notes sur quelques espèces distribuées cette année [1876]. Bulletin de la Société Dauphinoise pour l'Échange des Plantes [Première série de 1874 à 1889], 3: 69-84.

Webb C.J., Sykes W.R., Garnock-Jones P.J. 1988. Flora of New Zealand, vol. 4. Christchurch: Botany Division, Department of Scientific and Industrial Research (DSIR), lxviii + 1365 pp.

Yena A.V. 2005. Artemisia codonocephala. In: Greuter W., von Raab-Straube E. (Eds). Euro+Med Notulae, 1. Willdenowia, 35: 223-239.

Yena A.V. 2012. Spontaneous flora of the Crimean Peninsula. Simferopol: N. Orianda, 232 pp. [Ена A.В. 2012. Природная флора Крымского полуострова. Симферополь: Н. Оріанда, 232 с.].

Recommended for publication by

Submitted 23.01.2019 F. Verloove 


\title{
Паліноморфологія видів роду Dipsacus (Dipsacaceae) флори України: значення для цілей систематики та спорово-пилкового аналізу
}

\author{
Зоя М. ЦИМБАЛЮК, Людмила Г. БЕЗУСЬКО, Сергій Л. МОСЯКІН, Людмила М. НИЦЕНКО \\ Інститут ботаніки ім. М.Г. Холодного НАН України \\ вул. Терещенківська 2, Київ 01004, Україна \\ palynology@ukr.net
}

Tsymbalyuk Z.M., Bezusko L.G., Mosyakin S.L., Nitsenko L.M. 2019. Pollen morphology of species of Dipsacus (Dipsacaceae) in the flora of Ukraine: significance for taxonomy and spore-pollen analysis. Ukrainian Botanical Journal, 76(1): 9-23.

M.G. Kholodny Institute of Botany, National Academy of Sciences of Ukraine

2 Tereshchenkivska Str., Kyiv 01004, Ukraine

Abstract. Pollen morphology of six species of the genus Dipsacus (Dipsacaceae) in the flora of Ukraine was studied using light and scanning electron microscopy. Pollen grains of these species are 3-porate, spheroidal, ellipsoidal or oblate-spheroidal; largesized. Their outline in equatorial view is circular or oval, in polar view circular-triangular. Pores are distinct, lolongate, circular and elliptical, with an annulus and operculum. Sculpture exine is spinate-spinulate. Additional characters of taxa of Dipsacus diagnostic at the species level for the purposes of taxonomy are the dimensions of pollen and pores, shape of pores, width of the annulus, structure of the operculum, structure of the exine, and the size and location of spines. The size of pollen and pores, shape of pores, and the width of the annulus are promising for the pollen identification in the spore-pollen analysis. The exine sculpture can be used for identification of pollen at the generic level. Palynomorphological data are partly consistent with the traditional system of genus. The significance of morphological features of pollen grains of representatives of the genus Dipsacus is more obvious at the species level. The available paleofloristic data on the participation of pollen grains of Dipsacaceae in the composition of subfossil spore-pollen spectra and palynofloras of the deposits of the Upper Pleistocene - Holocene of Ukraine are generalized. The high degree of fluctuation in participation of pollen of representatives of Dipsacus in paleofloristic material has been revealed. The generalized data allowed to substantiate the possibility and significance of the use of the presented palynomorphological data for taxa of Dipsacus of the flora of Ukraine in the practice of palynological studies of the Pleistocene and Holocene deposits.

Keywords: diagnostic characters, Dipsacaceae, Dipsacus, fossil palynoflora, Holocene, morphology, paleofloristics, pollen, taxonomy, Ukraine, Upper Pleistocene

Цимбалюк 3.М., Безусько Л.Г., Мосякін С.Л., Ниценко Л.М. 2019. Паліноморфологія видів роду Dipsacus (Dipsacaceae) флори України: значення для цілей систематики та спорово-пилкового аналізу. Український ботанічний ж⿻рннал, 76(1): 9-23.

Реферат. 3 використанням світлового і сканувального електронного мікроскопів досліджено пилкові зерна шести видів роду Dipsacus (Dipsacaceae) флори України. Встановлено, що пилкові зерна вивчених видів 3-порові, сфероїдальні, еліпсоїдальні або сплющено-сфероїдальні за формою, в обрисах з екватора округлі або овальні, 3 полюса округло-трикутні; великих розмірів. Пори чіткі, переважно еліптичні, зрідка округлі, з внутрішнім обідком та кришечкою. Скульптура екзини шипувато-шипикувата. Додатковими діагностичними ознаками видового рівня роду Dipsacus для цілей систематики є розміри пилкових зерен і пор, форма пор, ширина обідка, будова кришечки, структура екзини, розмір та розташування шипів. Для визначення пилкових зерен при спорово-пилковому аналізі перспективними ознаками є розмір пилкових зерен та пор, форма пор, ширина обідка. Скульптуру екзини можна використовувати при ідентифікації пилку до родового рівня. Паліноморфологічні дані частково узгоджуються 3 розподілом видів за традиційною системою роду. Значення морфологічних особливостей пилкових зерен представників роду Dipsacus очевидніше на видовому рівні. Узагальнено існуючі на цей час палеофлористичні дані про участь пилкових зерен Dipsacaceae як у складі субфосильних спорово-пилкових спектрів, так і в палінофлорах відкладів верхнього плейстоцену-голоцену України. Встановлено високий ступінь фрагментарності участі пилку представників роду Dipsacus у палеофлористичних матеріалах. Узагальнені дані дозволили обгрунтувати актуальність та перспективність використання представленої паліноморфологічної розробки для роду Dipsacus флори України в практиці палінологічних досліджень відкладів плейстоцену та голоцену.

Ключові слова: верхній плейстоцен, викопна палінофлора, голоцен, діагностичні ознаки, морфологія, палеофлористика, пилкові зерна, систематика, Україна, Dipsacaceae, Dipsacus

(c) 3.М. ЦИМБАЛЮК, Л.Г. БЕЗУСЬКО, С.Л. МОСЯКІН, Л.М. НИЦЕНКО, 2019

Український ботанічний журнал, 2019, 76(1) 


\section{Вступ}

Рід Dipsacus L. згідно зі ст. 10.9 та 18.1 Міжнародного кодексу номенклатури водоростей, грибів та рослин (Turland et al., 2018) є типовим родом родини Dipsacaceae Juss. та порядку Dipsacales (Takhtajan, 1987, 1997, 2009; Reveal, 2012). За системою, що базується переважно на молекулярно-філогенетичних даних (APG III, 2009; APG IV, 2016), представників Dipsacaceae включають до родини Caprifoliaceae s. 1. (включно з Valerianaceae Batsch, Morinaceae Raf., Diervillaceae Pyck тощо). Молекулярно-філогенетичні дослідження представників родини Dipsacaceae і деяких споріднених родин проведені багатьма дослідниками (Donoghue et al., 1992; Caputo, Cozzolino, 1994; Bell et al., 2001; Bremer et al., 2001; Zhang et al., 2003; Caputo et al., 2004; Bell, Donoghue, 2005; etc.). 3a результатами молекулярних досліджень, родину Dipsacaceae (або загальну кладу, що включає цю групу) розділено на дві великі філогенетичні лінії (клади) (Carlson et al., 2009). Перша клада включає представників родів Pseudoscabiosa Devesa, Succisa Haller та Succisella Beck і є сестринською групою по відношенню до групи родів Knautia L., Pterocephalidium G. López, Dipsacus i Cephalaria Schrad. ex Roem. \& Schult. У цій кладі рід Knautia є сестринським по відношенню до Pterocephalidium, а рід Dipsacus - до Cephalaria. Друга клада включає роди Lomelosia Raf. та Pycnocomon Hoffmanns. $\&$ Link, які є сестринськими по відношенню до субклади, що містить Pterocephalus Vaill. ex Adans., який, у свою чергу, є сестринським до групи, що включає представників родів Scabiosa L. i Sixalix Raf. Подальші молекулярно-філогенетичні дослідження у поєднанні 3 морфологічними даними, вірогідно, дозволять дещо деталізувати й вдосконалити обговорену вище загальну філогенетичну схему.

У світовій флорі рід Dipsacus налічує близько 15 видів, які поширені переважно у Північній Америці, Середній і Східній Європі, Західній Азії та Східній Індії (Takhtajan, 1987, 2009; Backlund, Donoghue, 1996; Mabberley, 1997). Таксономічну обробку роду Dipsacus для флори колишнього СРСР проведено Є.Г. Бобровим (Bobrov, 1957). Автор наводить сім визнаних видів і включає їх до триби Dipsaceae Rchb.; з цих видів п'ять (D. sativus, D. laciniatus L., D. gmelinii M.Bieb., D. strigosus Willd., D. pilosus L.) представлені у флорі України.
Таксономічну обробку роду Dipsacus для флори України здійснено М.I. Котовим (Kotov, 1961). Він визнав шість видів, шо належать до двох підродів. С.Л. Мосякін та М.М. Федорончук (Mosyakin, Fedoronchuk, 1999) у номенклатурному конспекті судинних рослин України наводять шість визнаних видів роду Dipsacus.

Рід Dipsacus у паліноморфологічному аспекті досліджувався різними вченими. Раніше під світловим мікроскопом були охарактеризовані ознаки пилкових зерен роду загалом (Erdtman, 1952; Faegri, Iversen, 1964; Moore, Webb, 1983). Детальніше під світловим мікроскопом вивчено пилкові зерна D. gmelinii, D. pilosus (Vinokurova, 1959) та D. fullonum L. (Kupriyanova, Aleshina, 1972). 3 використанням світлового мікроскопу досліджено пилкові зерна шести видів цього роду (Clarke, Jones, 1981), з них пилок трьох видів вивчено під сканувальним електронним мікроскопом. В електронній базі даних PalDat є відомості про морфологію пилку $D$. fullonum та D. laciniatus, дослідженого під сканувальним електронним мікроскопом (Halbritter, 2016; Halbritter, Svojtka, 2016). Вивчено морфологічні особливості пилкових зерен D. inermis Wall. флори Пакистану (Perveen, Qaiser, 2011) та D. strigosus флори Ірану (Mostafa et al., 2017).

Одним із актуальних завдань сучасної палінології відкладів квартеру України є розвиток палеофлористичного напрямку досліджень, який переважно базується на родових та видових визначеннях викопного пилку (Bezusko et al., 2011; Sirenko, 2017) і потребує залучення новітніх комплексних паліноморфологічних розробок (Tsymbalyuk, Mosyakin, 2013; Tsymbalyuk, Bezusko, 2017a, b, c; Tsymbalyuk et al., 2018).

Отже, метою нашої роботи було вивчення пилку та детальна паліноморфологічна характеристика представників роду Dipsacus (види флори України), оцінка таксономічної значущості ознак пилкових зерен для уточнення питань систематики та можливості їхнього використання для визначення пилку при спорово-пилковому аналізі, узагальнення наявних на цей час відомостей про участь пилку представників роду Dipsacus у складі субфосильних спорово-пилкових спектрів та палінофлор відкладів верхнього плейстоценуголоцену України. 


\section{Матеріали та методи}

Для паліноморфологічних досліджень був використаний матеріал з Національного гербарію України (гербарій Інституту ботаніки ім. М.Г. Холодного НАН України - KW; акронім наведено за Index Herbariorum (Thiers, 2008-onward). Для дослідження пилкових зерен під світловим мікроскопом (Biolar, $\mathrm{CM)} \mathrm{матеріал} \mathrm{обробляли} \mathrm{за} \mathrm{загальноприйнятим}$ ацетолізним методом (Erdtman, 1952). Постійні препарати пилкових зерен представників роду Dipsacus зберігаються у палінотеці Національного гербарію України (Bezusko, Tsymbalyuk, 2011). Для вивчення пилку під сканувальним електронним мікроскопом (JSM-6060 LA, CEM) матеріал фіксували в 96\%-му етанолі та напилювали шаром золота за стандартною методикою. Описували пилкові зерна з використанням загальноприйнятої термінології (Kupriyanova, Aleshina, 1972; Tokarev, 2002; Punt et al., 2007), з окремими модифікаціями (Tsymbalyuk et al., 2018). Нами досліджено пилкові зерна шести видів (12 зразків) роду Dipsacus флори України.

При проведенні актуопалінологічних та палеофлористичних досліджень використали метод спорово-пилкового аналізу. Матеріалом для узагальнення відомостей про участь пилку представників роду Dipsacus були палінологічні характеристики поверхневих проб грунтів, відібрані з території України (Arap, 1972, 1974, 1976, 1984; Stuchlik, Kvavadze, 1995; Bezusko et al., 2011) та викопні палінофлори відкладів верхнього плейстоцену-голоцену України (Artyushenko, 1970; Artyushenko et al., 1973, 1982; Pashkevich, 1977, 1987; Kremenetskiy, 1991; Bolikhovskaya, 1995; Gerasimenko, 1997; Bezuskoetal., 2011; Bezusko, 2014; Gerasimenko et al., 2014; Sirenko, 2017). Зазначимо, що, враховуючи розподіл складу споровопилкового спектру на основні компоненти, який був запропонований В.П. Гричуком (Grichuk, 1989), пилкові зерна видів Dipsacaceae є локальним компонентом (пилок та спори, які переносяться повітрям на відстані, що вимірюються метрами). До цієї групи входить пилок комахозапилювальних (ентомофільних) трав'яних рослин і спори низькорослих спорових рослин. У практиці спорово-пилкових досліджень при ідентифікації викопних пилкових зерен родини Dipsacaceae здебільшого використовувались діагностичні ознаки, наведені у відомому визначнику пилку та спор (Kupriyanova, Aleshina, 1972).
Характеристики пилкових зерен вивчених видів наведено за традиційною системою, прийнятою M.I. Котовим (Kotov, 1961). Усі зразки зібрані на території України. Дані гербарних етикеток наведені мовою оригіналу.

\section{Результати та обговорення}

Триба Dipsaceae Rchb.

Dipsacus L.

Підрід 1. Virga (Hill) Beck

Dipsacus pilosus L. (рис. 1, A-C; рис. 4, A-D)

CM. Пилкові зерна (п. з.) 3-порові, сплющеносфероїдальні або еліпсоїдальні за формою, в обрисі з полюса округло-трикутні, 3 екватора округлі. Полярна вісь (п. в.) 66,5-79,8 мкм, екваторіальний діаметр (е. д.) 66,5-79,8 мкм. Пори чіткі, еліптичні, 11,9-19,9 мкм завдовжки, 4,0-10,6 мкм завширшки, 3 внутрішнім обідком, 2,7-4,0 мкм завтовшки, 3 кришечкою, що складається з паличкоподібних виростів та шипів. Більша частина кришечок зберігається, а менша втрачається після ацетолізної обробки, зрідка по краю пори залишаються окремі вирости та шипи. Екзина 5,3-7,9 мкм завтовшки. Ектекзина вдвічі товстіша за ендекзину. Покрив утричі тонший за стовпчиковий шар, ендекзина нерівномірно потовщена, вдвічі тонша за стовпчиковий шар. Стовпчики чіткі, розташовані більш-менш рівномірно. Скульптура екзини чітка, шипуватогранулярна; гранули різного розміру, розташовані щільно, шипи майже не помітні на поверхні зерна, по краю помітні, розташовані дуже рідко.

CEM. Скульптура екзини шипувато-шипикувата, складається з рідко розташованих шипів і шипиків, які порівняно 3 шипами розташовані щільніше; шипи та шипики конусоподібні за формою, з гострою верхівкою. Шипи 0,7-2,1 мкм заввишки, при основі $0,8-1,7$ мкм, шипики $0,2-0,4$ мкм заввишки, при основі $0,3-0,5$ мкм. Пори закриті кришечкою 3 паличкоподібними виростами та шипами. Зрідка пори звужені й ніби скидаються на борозни.

Досліджені зразки: 1. [м. Київ] Голосіїв, молодий грабовий ліс. 20.VII 1931. В. Михайличенко, Є. Карнаух (KW). 2. Крым, Симферопольский p-н, Перевальное лесничество, у края Долгоруковской яйлы, у опушки. 15.VIII 1971. М. Котов (KW). 3. На лесной поляне в грабовом лесу близ с. Нараев 


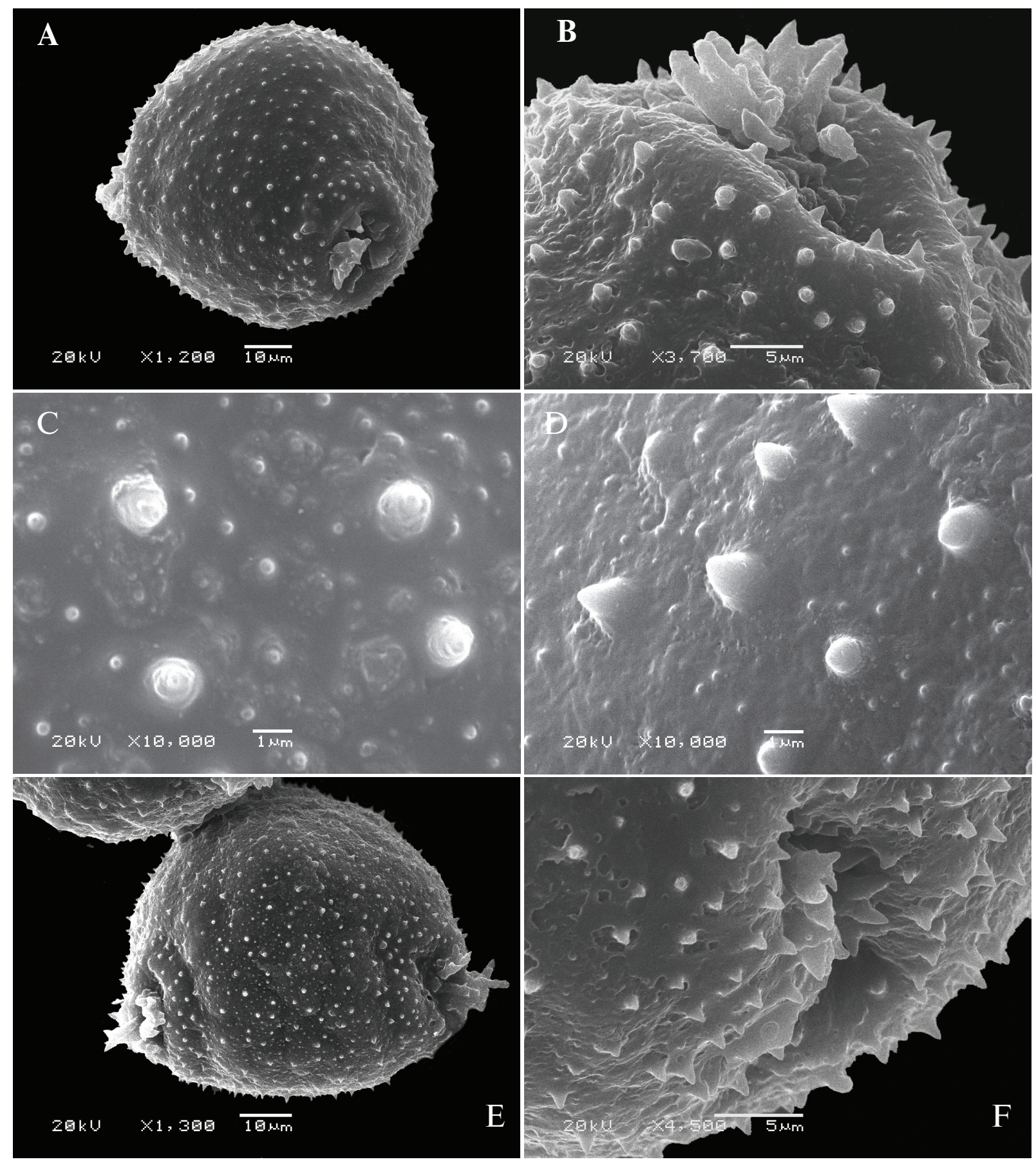

Рис. 1. Пилкові зерна роду Dipsacus (сканувальний електронний мікроскоп). А-C: D. pilosus; D-F: D. strigosus (A: вигляд з екватора; E: вигляд з полюса; B: паличкоподібні вирости по краю пори; F: кришечка; C, D: скульптура екзини)

Fig. 1. Pollen grains of Dipsacus (scanning electron microscopy). A-C: D. pilosus; D-F: D. strigosus (A: equatorial view; E: polar view; B: stick-shaped outgrowths on pore margin; F: operculum; C, D: exine sculpture) 


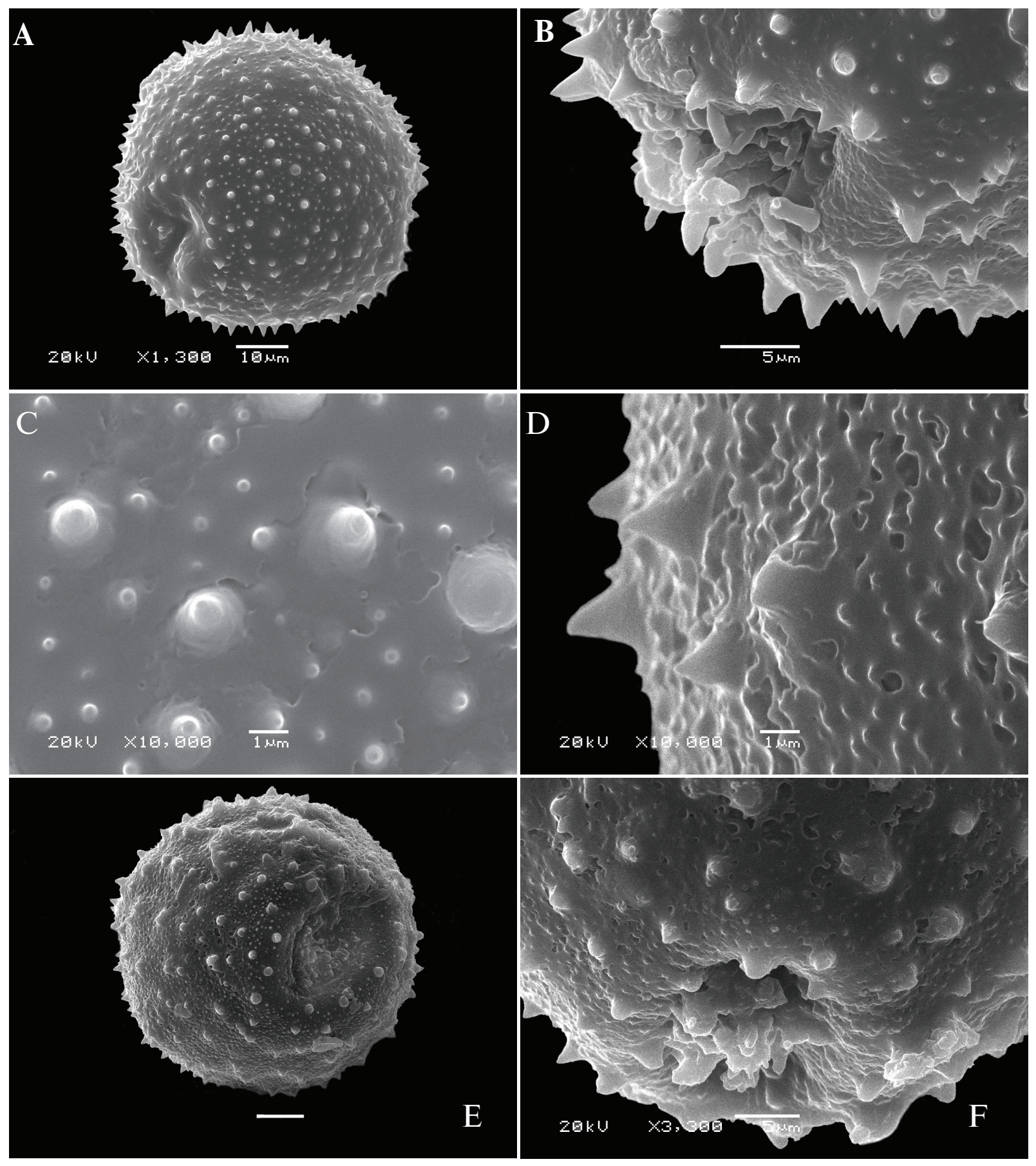

Рис. 2. Пилкові зерна роду Dipsacus (сканувальний електронний мікроскоп). A-C: D. gmelinii; D-F: D. sativus (A, Е: вигляд з екватора; B, F: кришечка; C, D: скульптура екзини). Масштабна лінійка. Е: 10 мкм

Fig. 2. Pollen grains of Dipsacus (scanning electron microscopy). A-C: D. gmelinii; D-F: D. sativus (A, E: equatorial view; B, F: operculum; C, D: exine sculpture). Scale bars. E: $10 \mu \mathrm{m}$ 


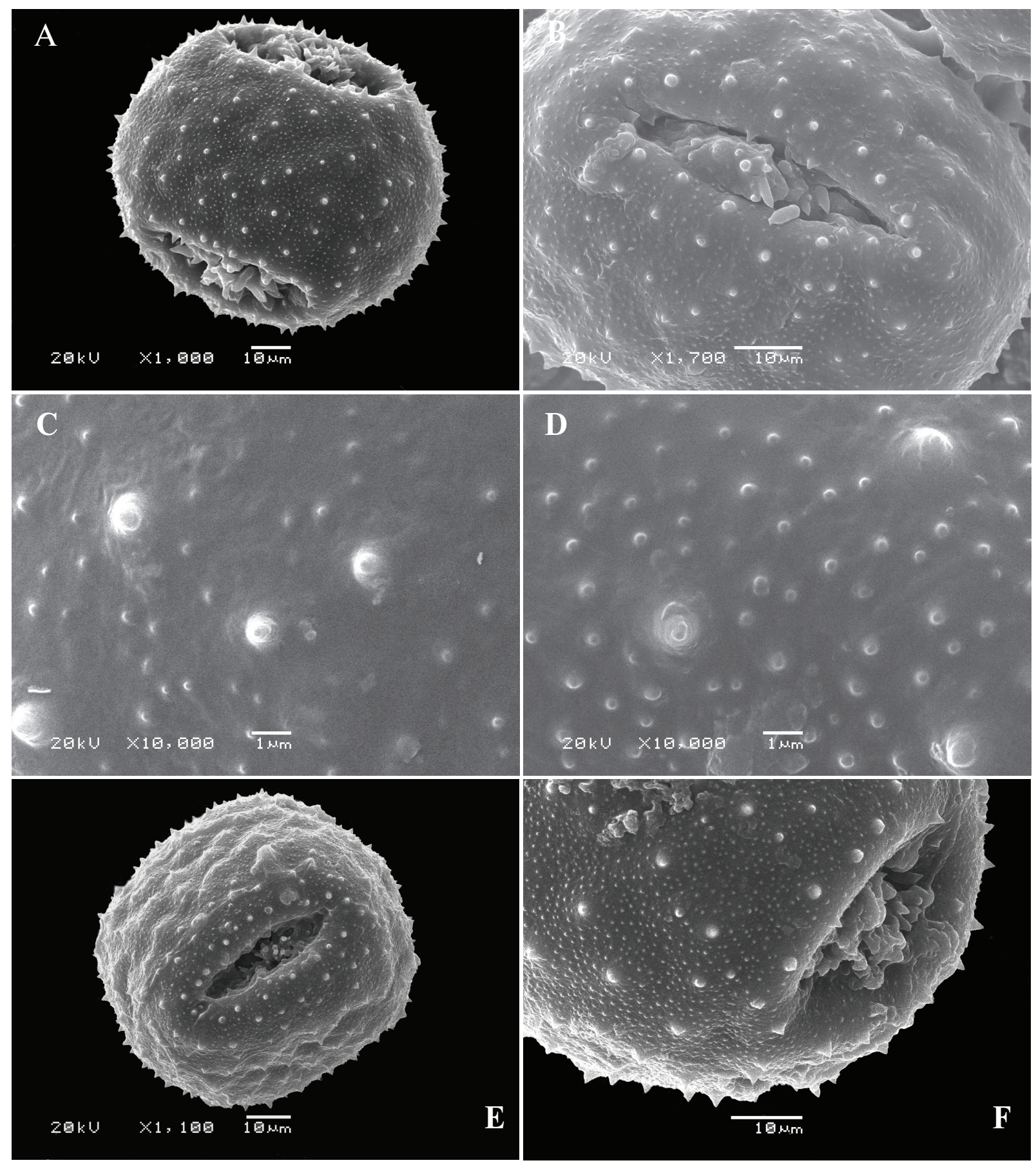

Рис. 3. Пилкові зерна роду Dipsacus (сканувальний електронний мікроскоп). А-C: D. laciniatus; D-F: D. sylvestris (A, Е: вигляд з екватора; В, F: кришечка; C, D: скульптура екзини)

Fig. 3. Pollen grains of Dipsacus (scanning electron microscopy). A-C: D. laciniatus; D-F: D. sylvestris (A, E: equatorial view; B, F: operculum; C, D: exine sculpture) 


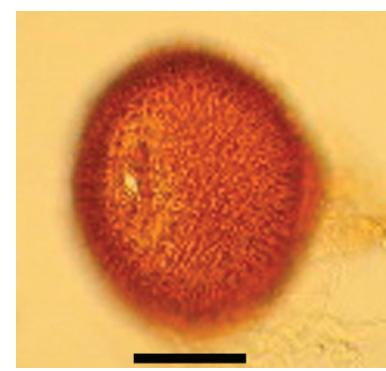

A

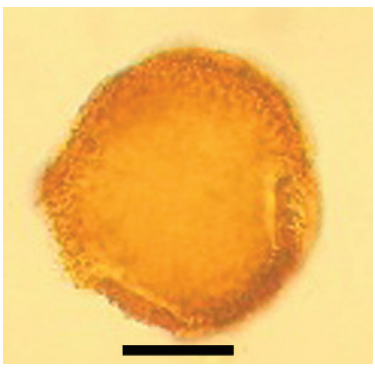

E

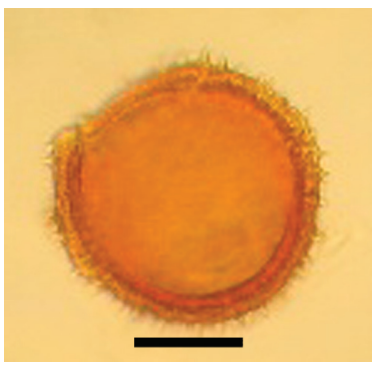

I

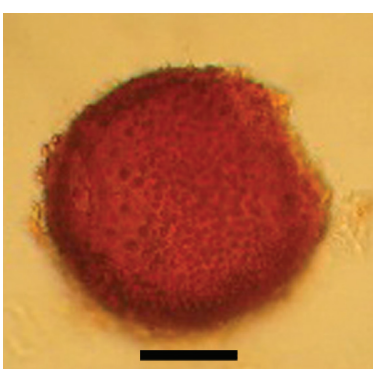

M

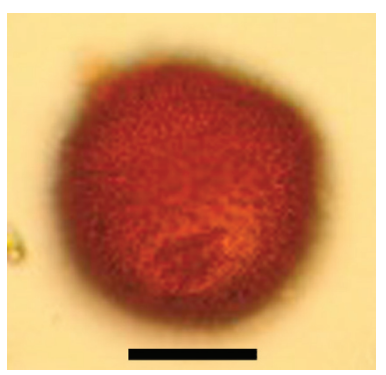

B

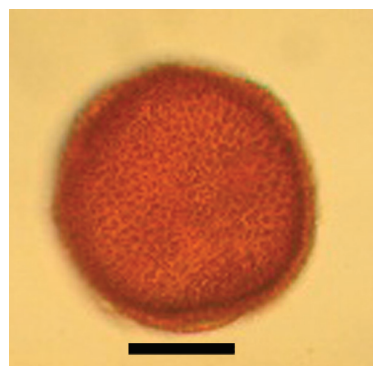

F

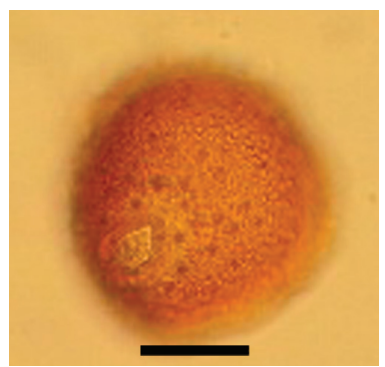

$\mathbf{J}$

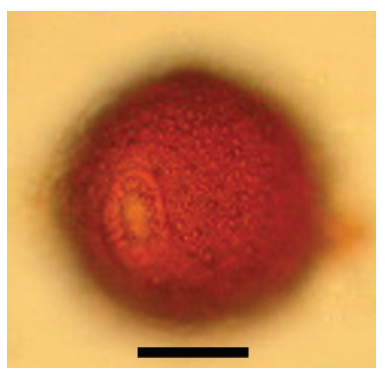

$\mathbf{N}$

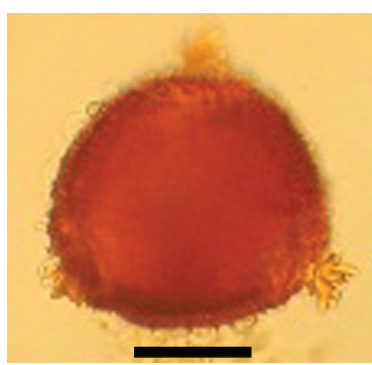

C

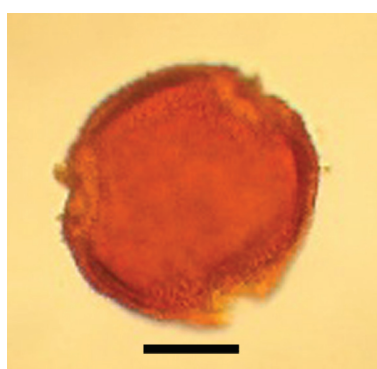

G

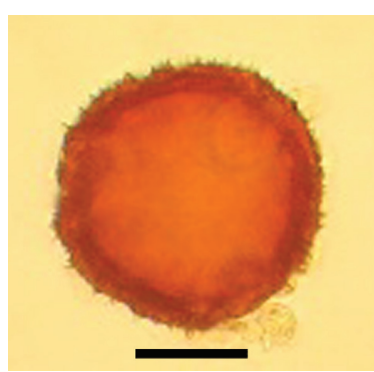

K

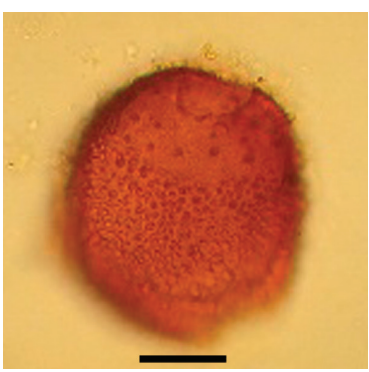

$\mathbf{O}$

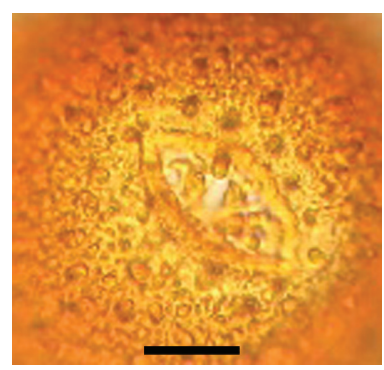

D

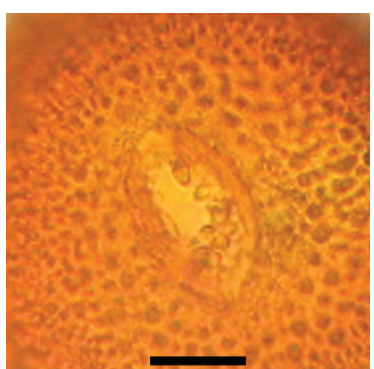

H

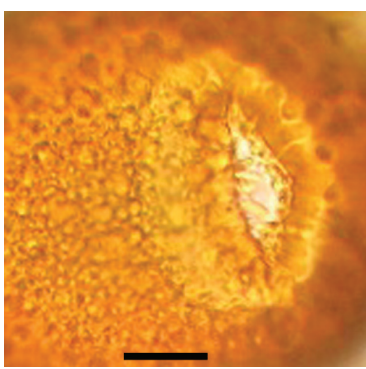

L

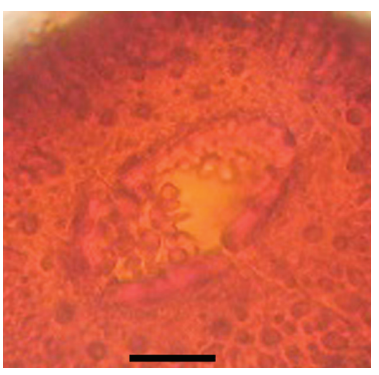

$\mathbf{P}$

Рис. 4. Пилкові зерна роду Dipsacus (світловий мікроскоп). A-D: D. pilosus; E-H: D. strigosus; I-L: D. gmelinii; M-P: D. sativus (A, B, E, I, J, M, N: вигляд з екватора, ×400; C, F, G, K, О: вигляд з полюса, ×400; D, H, L, P: пора 3 паличкоподібними виростами, ×700). Масштабна лінійка. А-P: 10 мкм

Fig. 4. Pollen grains of Dipsacus (light microscopy). A-D: D. pilosus; E-H: D. strigosus; I-L: D. gmelinii; M-P: D. sativus $(\mathrm{A}, \mathrm{B}, \mathrm{E}, \mathrm{I}, \mathrm{J}, \mathrm{M}, \mathrm{N}$ : equatorial view, $\times 400 ; \mathrm{C}, \mathrm{F}, \mathrm{G}, \mathrm{K}, \mathrm{O}$ : polar view, $\times 400$; D, H, L, P: pore with stick-shaped outgrowths, $\times 700)$. Scale bars. A-P: $10 \mu \mathrm{m}$ 
Бережанского р-на Тернопольской обл. 26.VII 1940. Собр. Данилевская, опр. Е. Карнаух (KW).

Dipsacus strigosus Willd. ex Roem. \& Schult. (рис. 1, D-F; рис. 4, E-H)

СМ. П. з. 3-порові, еліпсоїдальні або сфероїдальні, зрідка сплющено-сфероїдальні за формою, в обрисі з полюса округло-трикутні, округлі, 3 екватора овальні або округлі. П. в. 74,5-93,1 мкм, е. д. 71,8-87,8 мкм. Пори чіткі, еліптичні, 11,918,6 мкм завдовжки, 6,6-7,9 мкм завширшки, 3 внутрішнім обідком, 2,7-4,0 мкм завтовшки, 3 кришечкою, що складається $з$ паличкоподібних виростів та шипів. Більша частина кришечок втрачається, а менша зберігається після ацетолізної обробки. Екзина 6,6-9,3 мкм завтовшки. Ектекзина майже дорівнює або тонша за ендекзину. Покрив утричі тонший за стовпчиковий шар, ендекзина нерівномірно потовщена, в 1,5 разів тонша або майже дорівнює стовпчиковому шару. Стовпчики чіткі, розташовані більш-менш рівномірно. Скульптура екзини чітка, шипувато-гранулярна; гранули різного розміру, розташовані щільно, шипи майже не помітні по краю зерна.

CEM. Скульптура екзини шипувато-шипикувата, складається з рідко розташованих шипів і шипиків, які порівняно з шипами розташовані щільніше; шипи та шипики конусоподібні за формою, з гострою верхівкою. Шипи 0,8-1,5 мкм заввишки, при основі 0,7-1,3 мкм, шипики 0,2-0,3 мкм заввишки, при основі 0,3-0,4 мкм. Пори закриті кришечкою 3 паличкоподібними виростами та шипами.

Досліджені зразки: 1. Ворошиловградская [нині Луганська] обл., Лимаревский р-н, Лимаревский гос. кон. завод, пойма р. Деркула, между кустарниками. 2.VIII 1938. Н. Косец (KW). 2. Сталинская [нині Донецька] обл., Красноармейский [нині Покровський] p-н, с. Игнатьевка [нині Гнатівка], лес по балке. 1930. Ю. Клеопов, М. Котов (KW).

\section{Підрід 2. Dipsacus}

Dipsacus gmelinii M.Bieb. (рис. 2, А-С; рис. 4, I-L)

СМ. П. з. 3-порові, сфероїдальні, сплющеносфероїдальні, зрідка еліпсоїдальні за формою, в обрисі з полюса округло-трикутні, з екватора округлі або овальні. П. в. 66,5-79,8 мкм, е. д. 63,886,4 мкм. Пори чіткі, еліптичні, 15,9-26,6 мкм завдовжки, 4,0-7,9 мкм завширшки, з внутрішнім обідком, 2,7-4,0 мкм завтовшки, з кришечкою, що складається з паличкоподібних виростів і шипів. Більша частина кришечок втрачається, а менша зберігається після ацетолізної обробки. Екзина 6,6-9,3 мкм завтовшки. Ектекзина майже дорівнює або тонша за ендекзину. Покрив удвічі тонший за стовпчиковий шар, ендекзина нерівномірно потовщена, вдвічі тонша або майже дорівнює стовпчиковому шару. Стовпчики чіткі, розташовані більш-менш рівномірно. Скульптура екзини чітка, шипувато-гранулярна; гранули різного розміру, розташовані щільно, шипи з гострою верхівкою, добре помітні по краю зерна, розташовані рідко.

CEM. Скульптура екзини шипувато-шипикувата, складається з рідко розташованих шипів і шипиків, які порівняно $з$ шипами, розташовані щільніше; шипи й шипики конусоподібні за формою, з гострою верхівкою. Шипи 1,6-2,7 мкм заввишки, при основі 1,4-1,9 мкм, шипики 0,3-0,4 мкм заввишки, при основі 0,3-0,5 мкм. Пори закриті кришечкою 3 паличкоподібними виростами та шипами, зрідка вирости розташовані по краю пори або по центру порової мембрани.

Досліджені зразки: 1. Запорожская обл., Конские плавни, Яківлівська плавня (Мыс Доброй Надежды). 19.VIII 1925. О. Соколовський (KW). 2. Запорожская обл., Каменско-Днепровский р-н, с. Благовещенка, Конские плавни. 19.VIII 1930. M. Котов (KW).

Dipsacus sativus (L.) Honck. (рис. 2, D-F; рис. 4, $\mathrm{M}-\mathrm{P}$ )

СМ. П. 3. 3-порові, сплющено-сфероїдальні або сфероїдальні за формою, в обрисі з полюса округлотрикутні, з екватора округлі. П. в. 79,9-97,1 мкм, е. д. 74,5-97,1 мкм. Пори чіткі, еліптичні, 15,923,9 мкм завдовжки, 6,6-13,3 мкм завширшки, з внутрішнім обідком, 2,7-6,6 мкм завтовшки, з кришечкою, що складається 3 паличкоподібних виростів та шипів або паличкоподібні вирости розташовані по краю пори. Більша частина кришечок втрачається, а менша зберігається після ацетолізної обробки. Екзина 6,6-7,9 мкм завтовшки. Ектекзина втричі товстіша за ендекзину. Покрив утричі тонший за стовпчиковий шар, ендекзина нерівномірно потовщена, удвічі тонша за стовпчиковий шар. Стовпчики нечіткі. Скульптура екзини чітка, шипувато-гранулярна; гранули різного розміру, розташовані щільно, шипи з гострою, зрідка із загнутою верхівкою, помітні по краю зерна, розташовані рідко. 


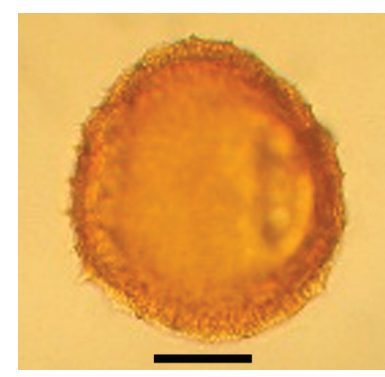

A

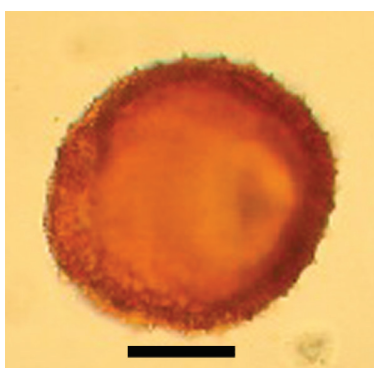

E

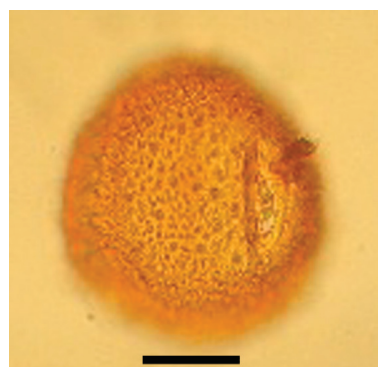

B

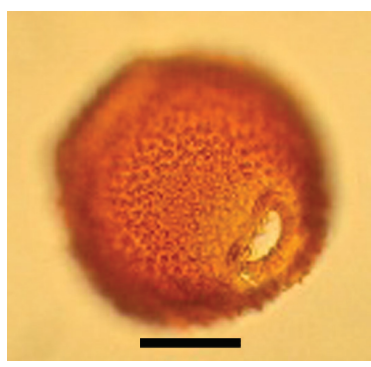

$\mathrm{F}$

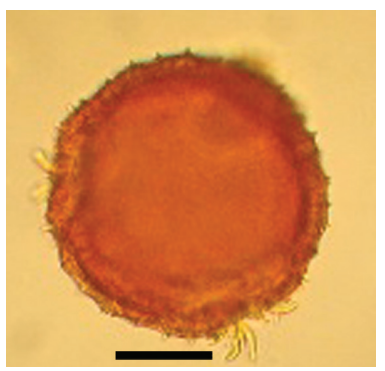

$\mathrm{C}$

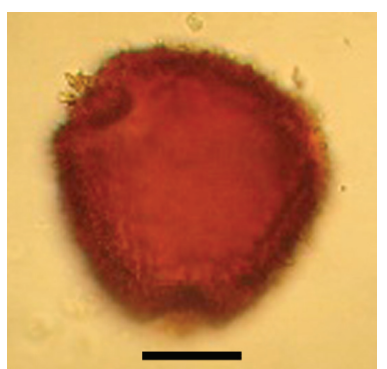

G

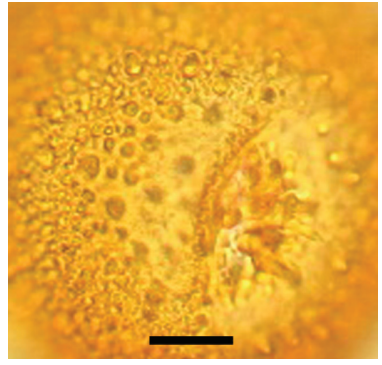

$\mathrm{D}$

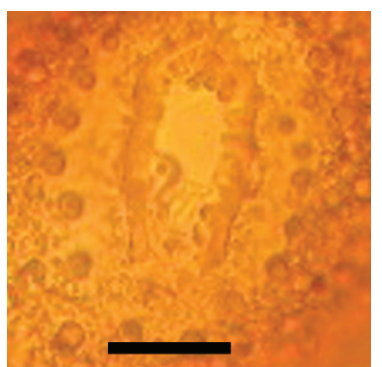

$\mathrm{H}$

Рис. 5. Пилкові зерна роду Dipsacus (світловий мікроскоп). А-D: D. laciniatus; E-H: D. sylvestris (A, В, E, F: вигляд 3 екватора, ×400; C, G: вигляд з полюса, ×400; D: пора з кришечкою, ×700; Н: пора, ×700). Масштабна лінійка. А-Н: 10 MKM

Fig. 5. Pollen grains of Dipsacus (light microscopy). A-D: D. laciniatus; E-H: D. sylvestris (A, B, E, F: equatorial view, $\times 400$; C, G: polar view, $\times 400$; D: pore with operculum, $\times 700$; H: pore, $\times 700)$. Scale bars. A-H :10 $\mu \mathrm{m}$

CEM. Скульптура екзини шипувато-шипикувата, складається з рідко розташованих шипів i шипиків, які порівняно 3 шипами розташовані щільніше; шипи й шипики конусоподібні за формою, переважно $з$ гострою, зрідка 3 загнутою верхівкою. Шипи 1,1-2,0 мкм заввишки, при основі 1,1-2,1 мкм, шипики 0,2-0,4 мкм заввишки, при основі 0,3-0,6 мкм. Пори закриті кришечкою 3 паличкоподібними виростами та шипами, які розташовані щільно, майже зливаються, або паличкоподібні вирости розташовані по краю пори.

Досліджений зразок: Киевская губ. Радом. уезда, около м. Хабное [нині Поліське, колишній районний центр Поліського району Київської обл., зараз у зоні відчуження Чорнобильської АЕС]. 22.VI 1853. А. Рогович [культивоване?] (KW).

Dipsacus laciniatus L. (рис. 3, A-C; рис. 5, A-D)

CM. П. з. 3-порові, еліпсоїдальні, зрідка сфероїдальні або сплющено-сфероїдальні за формою, в обрисі з полюса округло-трикутні, з екватора овальні або округлі, по краю хвилясті. П. в. 75,8-103,7 мкм, е. д. 75,8-93,1 мкм. Пори чіткі, еліптичні, 15,9-26,6 мкм завдовжки, 5,3-11,9 мкм Український ботанічний журнал, 2019, 76(1) завширшки, з обідком, 2,4-4,0 (5,3) мкм завтовшки, 3 кришечкою, шо складається з паличкоподібних виростів. Більша частина кришечок зберігається, а менша втрачається після ацетолізної обробки. Екзина 6,6-10,6 мкм завтовшки. Ектекзина вдвічі товстіша за ендекзину. Покрив удвічі тонший за стовпчиковий шар, ендекзина нерівномірно потовщена, удвічі тонша за стовпчиковий шар. Стовпчики чіткі, розташовані більш-менш рівномірно. Скульптура екзини чітка, шипуватогранулярна; гранули різного розміру, розташовані щільно, шипи з гострою верхівкою, слабко помітні по краю, розташовані рідко.

CEM. Скульптура екзини шипувато-шипикувата, складається $з$ рідко розташованих шипів і шипиків, які порівняно 3 шипами розташовані щільніше; шипи й шипики конусоподібні за формою, з гострою верхівкою. Шипи 1,4-2,7 мкм заввишки, при основі 1,2-1,8 мкм, шипики 0,3-0,5 мкм заввишки, при основі 0,3-0,5 мкм. Пори закриті кришечкою 3 паличкоподібними виростами $з$ шипами та шипиками, або вирости розташовані по краю пори, по центру або по всій 
поверхні порової мембрани. Зрідка пори звужені й закриті, скидаються на борозни.

Досліджені зразки: 1. Хмельницька обл., Сатанівський р-н [нині у складі Городоцького p-ну], с. Кринцілів, грабовий ліс. 8.VIII 1973. C.C. Морозюк (KW). 2. Сталинская [нині Донецька] обл., Володарский р-н, з-к "Каменные Могилы", балка. 20.VII 1957. Л. Панова (KW).

Dipsacus sylvestris Huds. (рис. 3, D-F; рис. 5, E-H)

CM. П. 3. 3-порові, сфероїдальні, сплющеносфероїдальні, зрідка еліпсоїдальні за формою, в обрисі з полюса округло-трикутні, з екватора округлі або овальні. П. в. 66,5-89,1 мкм, е. д. 74,5-90,4 мкм. Пори чіткі, переважно округлі, зрідка еліптичні, 5,3-18,6 мкм завдовжки, 5,310,6 мкм завширшки, з внутрішнім обідком, 2,44,0 мкм завтовшки, з кришечкою, що складається 3 паличкоподібних виростів. Більша частина кришечок втрачається, а менша зберігається після ацетолізної обробки. Екзина 6,6-9,3 мкм завтовшки. Ектекзина майже дорівнює або тонша за ендекзину. Покрив удвічі тонший за стовпчиковий шар, ендекзина нерівномірно потовщена, вдвічі тонша або майже дорівнює стовпчиковому шару. Стовпчики чіткі, розташовані більш-менш рівномірно. Скульптура екзини чітка, шипуватогранулярна; гранули різного розміру, розташовані щільно, шипи 3 гострою верхівкою, помітні по краю, розташовані рідко.

CEM. Скульптура екзини шипувато-шипикувата, складається з рідко розташованих шипів і шипиків, які порівняно з шипами, розташовані щільніше; шипи й шипики конусоподібні за формою, з гострою верхівкою. Шипи 1,7-2,4 мкм заввишки, при основі 1,6-1,8 мкм, шипики 0,3-0,5 мкм заввишки, при основі 0,3-0,5 мкм. Пори закриті кришечкою 3 паличкоподібними виростами та шипами або вирости розташовані по краю пори. Зрідка пори звужені й закриті, скидаються на борозни.

Досліджені зразки: 1. Тульчинська округа. У х. Выдра, к N в 4 км от с. Пирожна [нині с. Пиріжна Кодимського р-ну Одеської обл.], сорное у дороги. 5.VIII 1929. М. Котов (KW). 2. Проскурівська округа. Между с. Гришки и с. Чернелевцы [нині с. Чернелівці Деражнянського р-ну Хмельницької обл.], у дороги. 1.VIII 1928. М. Котов (KW).

Результати досліджень показали, що пилкові зерна всіх вивчених видів роду Dipsacus 3-порові.
При дослідженні пилкових зерен під сканувальним електронним мікроскопом у деяких видів, зокрема, D. laciniatus та D. sylvestris зрідка пори дещо закриті й скидаються на борозни (рис. 3). Пилкові зерна сфероїдальні, еліпсоїдальні або сплющеносфероїдальні за формою, в обрисі $з$ полюса округло-трикутні, зрідка округлі, 3 екватора округлі або овальні; великих розмірів, полярна вісь становить 66,5-103,7 мкм, екваторіальний діаметр 63,8-97,1 мкм. Найбільші пилкові зерна характерні для D. laciniatus. У пилкових зерен усіх досліджених видів пори чіткі, переважно еліптичні, у D. sylvestris округлі, зрідка еліптичні, 5,3-26,6 мкм завдовжки, 4,0-11,9 мкм завширшки, з внутрішнім обідком, 2,0-6,6 мкм завтовшки. Пори закриті кришечкою 3 паличкоподібними виростами, які зрідка розташовані по краю пори. Після ацетолізної обробки кришечки частіше втрачаються, але найщільніше прикріплені кришечки властиві для пилкових зерен $D$. pilosus і D. laciniatus.

Екзина товста, 5,3-10,6 мкм завтовшки. Ектекзина удвічі або утричі товстіша, майже дорівнює, або тонша за ендекзину. Покрив удвічі або утричі тонший за стовпчиковий шар; ендекзина нерівномірно потовщена, в 1,5 разів, удвічі тонша, або майже дорівнює стовпчиковому шару. Стовпчики чіткі, товсті, розташовані більш-менш рівномірно, або нечіткі. Пилкові зерна D. gmelinii та D. sylvestris подібні за співвідношенням шарів екзини, інші види розрізняються за структурою екзини.

Скульптура екзини шипувато-шипикувата, складається з рідко розташованих шипів і шипиків, причому шипики розташовані щільніше порівняно з шипами. Шипи і шипики конусоподібної форми, з гострою верхівкою. Шипи 0,7-2,7 мкм заввишки, при основі 0,7-2,1 мкм; шипики 0,2-0,5 мкм заввишки, при основі 0,2-0,6 мкм. Найменші шипи характерні для пилкових зерен D. strigosus.

Ми співставили результати паліноморфологічних досліджень $з$ системою роду Dipsacus, прийнятою M.I. Котовим (Kotov, 1961). Види підроду Virga, D. pilosus i D. strigosus подібні за розміром пор, шириною обідка й скульптурою екзини та відрізняються за іншими ознаками. Зокрема, пилкові зерна D. pilosus мають дещо менші розміри, ніж у D. strigosus, та щільніше прикріплені кришечки. Ці два види відрізняються за особливостями структури екзини, зокрема 
за співвідношенням шарів екзини. Також для пилкових зерен $D$. pilosus характерні більші шипи.

Серед видів підроду Dipsacus пилкові зерна D. gmelinii мають менші розміри, а D. laciniatus більші. Пилкові зерна D. sativus вирізняються за структурою екзини та дещо ширшим обідком. Пилковим зернам D. sylvestris характерні переважно більш округлі пори, на відміну від еліптичних в інших видів. Варто також відзначити, що у пилкових зерен $D$. gmelinii та $D$. sativus шипи розташовані щільніше, ніж у пилку D. laciniatus i D. sylvestris.

Результати нашого дослідження доводять, що пилкові зерна видів підроду Virga загалом характеризуються меншими шипами, на відміну від пилку видів підроду Dipsacus. Інші ознаки у пилкових зерен представників цих підродів перекриваються. Таким чином, значення особливостей морфології пилкових зерен краще проявляється на видовому рівні. За результатами молекулярнофілогенетичних досліджень (Carlson et al., 2009) види підроду Virga, D. pilosus і D. strigosus внесені до однієї підклади, що частково узгоджується 3 морфологічними особливостями пилкових зерен. Оскільки молекулярно-філогенетичними методами поки ще досліджена невелика кількість видів роду Dipsacus, порівняння філогенетичних свідчень 3 паліноморфологічними даними ускладнене.

Результати аналізу субфосильних споровопилкових спектрів з території України (Zubets, 1971; Arap, 1972, 1974, 1976, 1984; Bolikhovskaya, 1981; Stuchlik, Kvavadze, 1995; Bezusko et al., 2011) свідчать про те, що пилок Dipsacaceae був переважно ідентифікований на рівні родини. На території Українських Карпат пилкові зерна Dipsacaceae трапляються у складі палінологічних характеристик поверхневих проб грунтів, відібраних у субальпійському поясі (полонини Пожижевська, 1700 м. над р. м. та Рівна, 1482 м над р. м.) (Arap, 1984). Пилок Dipsacaceae спорадично в невеликій кількості зафіксовано в складі субфосильних спорово-пилкових спектрів, відібраних на території Лісостепової (Природний заповідник "Михайлівська цілина") (Arap, 1972) та Степової (біосферні заповідники "АсканіяНова" ім. Ф.Е. Фальц-Фейна та Чорноморський; Український степовий природний заповідник [відділення "Хомутовський степ" та "Кам'яні Могили"]; Казантипський природний заповідник;
Національний заповідник "Хортиця"; ландшафтний заказник "Обіточна коса", схили Куяльницького лиману, Арабатська стрілка) зон України (Zubets, 1971; Bezusko et al., 2011). На видовому рівні були зафіксовані знахідки пилкових зерен Knautia arvensis L. (Bezusko et al., 2011), на родовому Scabiosa sp. (Kremenetskiy, 1991). Відмітимо, що на цей час пилкові зерна представників роду Dipsacus були нами ідентифіковані лише в складі двох палінологічних характеристик поверхневих шарів грунтів, відібраних на Правобережжі Степової зони України (схили Куяльницького лиману - підзона типчаково-ковилових степів; Національний заповідник "Хортиця" - підзона різнотравно-типчаковоковилових степів).

Аналіз результатів палінологічного вивчення відкладів плейстоцену-голоцену України (Artyushenko, 1970; Artyushenko et al., 1973, 1982; Pashkevich, 1977, 1987; Kremenetskiy, 1991; Bolikhovskaya, 1995; Gerasimenko, 1997; Simakova, Puzachenko, 2008; Bezusko et al., 2011; Bezusko, 2014; Gerasimenko et al., 2014; Sirenko, 2017) свідчить про відсутність відомостей про пилок представників роду Dipsacus у складі викопних палінофлор. Здебільшого до викопних палінофлор у невеликій кількості входять пилкові зерна родини Dipsacaceae, які не визначені детальніше (Artiushenko et al., 1982; Simakova, Puzachenko, 2008; Bezusko et al., 2011; Bezusko, 2014; Gerasimenko et al., 2014; Sirenko, 2017). Варто відмітити, що до складу викопної флори відкладів максимуму останнього зледеніння (Last Glacial Maximum - LGM) з території Волинської височини входять пилкові зерна роду Scabiosa та S. ochroleuca L. (Bezusko, 2014). Видову складову деяких палінофлор відкладів плейстоценуголоцену України формує пилок Knautia arvensis (Grichuk, 1972; Gubonina, 1975; Bezusko et al., 2011). Результати аналізу та узагальнення існуючих на цей час палеофлористичних матеріалів свідчать про участь пилкових зерен $K$. arvensis у видовій складовій палінофлор відкладів аллередуголоцену, що дозволило нам уперше реконструювати просторово-часову диференціацію поширення цього виду на рівнинній частині України (Tsymbalyuk et al., 2018).

Наведені нами результати палеофлористичних досліджень показали, що в практиці палінологічного вивчення як субфосильних проб, так і відкладів плейстоцену-голоцену України існують суттєві труднощі при визначенні 
пилкових зерен Dipsacaceae до родового та видового рівнів. Припускаємо, що при проведенні палеопалінологічних досліджень частина викопного пилку представників роду Dipsacus була віднесена до родини Dipsacaceae (без детальнішої ідентифікації), що можна пояснити фрагментарністю паліноморфологічних даних для представників цієї родини.

Узагальнені результати проведених нами паліноморфологічних досліджень показали, що морфологічні ознаки пилкових зерен видів роду Dipsacus добре простежуються під світловим мікроскопом та є перспективними при визначенні викопного пилку для цілей палеопалінології. Ідентифікація викопного пилку на родовому та особливо видовому рівнях передбачає його добру збереженість. Враховуючи це, ми пропонуємо використовувати такий комплекс ознак: розмір пилкових зерен та пор, форма пор і ширина обідка. Скульптура екзини під світловим мікроскопом у пилкових зерен усіх видів шипувато-гранулярна, не має значення для визначення пилку на видовому рівні, але може використовуватись при його ідентифікації до родового рівня. Отримані нами результати паліноморфологічного вивчення видів роду Dipsacus є важливими при проведенні палеофлористичних досліджень відкладів плейстоцену-голоцену, що дозволить суттєво деталізувати як природні, так і антропогенні зміни у складі рослинного покриву України та суміжних територій.

\section{Висновки}

Нами досліджено та проаналізовано морфологічні ознаки пилкових зерен шести видів роду Dipsacus флори України. Встановлено, що важливими діагностичними ознаками видового рівня для цілей систематики є розміри пилкових зерен i пор, форма пор, ширина обідка, будова кришечки, структура екзини, розмір та розташування шипів. Для визначення пилкових зерен при спорово-пилковому аналізі перспективними ознаками є розмір пилкових зерен та пор, форма пор, ширина обідка. Скульптуру екзини можна використовувати при ідентифікації пилку до родового рівня. Паліноморфологічні дані не повністю узгоджуються $з$ традиційною системою роду. Морфологічні особливості пилкових зерен представників роду Dipsacus особливо вагомі на рівні видів.
За результатами палеофлористичних досліджень проаналізовано та узагальнено відомості про участь пилкових зерен як представників роду Dipsacus, так і родини Dipsacaceae у складі палінологічних характеристик поверхневих проб грунтів та палінофлор відкладів верхнього плейстоцену-голоцену України. На основі отриманих палеофлористичних матеріалів обгрунтовано актуальність і перспективність використання нової паліноморфологічної розробки роду Dipsacus флори України для деталізації реконструкції основних змін у складі рослинного покриву впродовж пізнього плейстоцену-голоцену.

\section{СПИСОК ПОСИЛАНЬ}

Angiosperm Phylogeny Group III (APG III). 2009. An update of the Angiosperm Phylogeny Group classification for the orders and families of flowering plants: APG III. Botanical Journal of the Linnean Society, 161: 105-121.

Angiosperm Phylogeny Group IV (APG IV). 2016. An update of the Angiosperm Phylogeny Group classification for the orders and families of flowering plants: APG IV. Botanical Journal of the Linnean Society, 181: 1-20.

Arap R.Ya. 1972. Ukrainian Botanical Journal, 29(4): 506513. [Арап Р.Я. 1972. Палінологічні дослідження поверхневих шарів грунту лісостепової частини УРСР. Український ботанічний журнал, 29(4): 506-513].

Arap R.Ya. 1974. Ukrainian Botanical Journal, 31(1): 493498. [Арап Р.Я. 1974. Співвідношення рецентних спорово-пилкових спектрів і складу рослинного покриву Волинського Полісся. Український ботанічний журнал, 31(1): 493-498].

Arap R.Ya. 1976. Palinologicheskie issledovaniya poverkhnostnykh sloev pochvy Ukrainskogo Polesya. In: Palinologicheskie issledovaniya osadochnykh otlozheniy Ukrainyi smezhnykh territoriy. Kiev: Naukova Dumka, pp. 11-16. [Арап Р.Я. 1976. Палинологические исследования поверхностных слоев почвы Украинского Полесья. В кн.: Палинологические исследования осадочных отложений Украины и смежных территорий. Киев: Наукова думка, с. 11-16].

Arap R.Ya. 1984. Ukrainian Botanical Journal, 41(1): 73-77. [Арап Р.Я. 1984. Палінологічні дослідження субфосильних проб з Українських Карпат. Український ботанічний журнал, 41(1): 73-77].

Artyushenko A.T. 1970. Rastitelnost Lesostepi i Stepi Ukrainy $v$ chetvertichnom periode (po dannym sporovo-pyltsevogo analiza). Kiev: Naukova Dumka, 176 pp. [Артюшенко А.Т. 1970. Растительность Лесостепи и Степи Украины в четвертичном периоде (по данным спорово-пыльцевого анализа). Киев: Наукова думка, 176 с.].

Artyushenko A.T., Arap R.Ya., Bezusko L.G. 1982. Istoriya rastitelnosti zapadnykh oblastey Ukrainy $v$ chetvertichnom periode. Kiev: Naukova Dumka, 136 pp. [Артюшенко А.Т., Арап Р.Я., Безусько Л.Г. 1982. История рас-

Ukrainian Botanical Journal, 2019, 76(1) 
тительности западных областей Украины в четвертичном периоде. Киев: Наукова думка, 136 с.].

Artyushenko A.T., Pashkevich G.A., Parishkura S.I., Kareva E.V. 1973. Paleobotanicheskaya kharakteristika opornykh razrezov chetvertichnykh (antropogenovykh) otlozheniy sredney i yuzhnoy chasti Ukrainy. Kiev: Naukova Dumka, 96 pp. [Артюшенко А.Т., Пашкевич Г.А., Паришкура С.И., Карева Е.В. 1973. Палеоботаническая характеристика опорных разрезов четвертичных (антропогеновых) отложений средней и южной части Украины. Киев: Наукова думка, 96 с.].

Backlund A., Donoghue M.J. 1996. Morphology and phylogeny of the order Dipsacales. In: Phylogeny of the Dipsacales, part 4. Ed. A. Backlund. Uppsala (Sweden): Uppsala Univ., pp. 1-55.

Bell C.D., Donoghue M.J. 2005. Dating the diversification of Dipsacales: comparing models, genes, and evolutionary implications. American Journal of Botany, 92: 284-314.

Bell C.D., Edwards E.J., Kim S.-T., Donoghue M.J. 2001. Dipsacales phylogeny based on chloroplast DNA sequences. Harvard Papers in Botany, 6(2): 481-499.

Bezusko L.G., Tsymbalyuk Z.M. 2011. Palynotheka of the M.H. Kholodny Institute of Botany, National Academy of Sciences of Ukraine. In: Herbaria of Ukraine. Index Herbariorum Ucrainicum. Ed. N.M. Shiyan. Kyiv: Alterpress, pp. 138-141. [Безусько Л.Г., Цимбалюк 3.М. 2011. Палінотека Інституту ботаніки ім. М.Г. Холодного НАН України. В кн.: Гербарії України. Index Herbariorum Ucrainicum. Ред. Н.М. Шиян. Київ: Альтерпрес, с. 138-141].

Bezusko L.H. 2014. Ukrainian Botanical Journal, 71(6): 694-701. [Безусько Л.Г. 2014. Нові палінологічні характеристики підкрасилівського лесу Волинської височини. Український ботанічний журнал, 71(6): 694-701].

Bezusko L.H., Mosyakin S.L., Bezusko A.H. 2011. Zakonomirnosti ta tendentsii rozvytku roslynnoho pokryvu Ukrainy u piznomu pleystotseni ta holotseni. Kyiv: Alterpress, 448 pр. [Безусько Л.Г., Мосякін С.Л., Безусько А.Г. 2011. Закономірності та тенденції розвитку рослинного покриву України у пізньому плейстоцені та голоцені. Київ: Альтерпрес, 448 с.].

Bobrov E.G. 1957. Dipsacaceae. In: Flora SSSR, vol. 24. Eds B.K. Shishkin, E.G. Bobrov. Moscow; Leningrad: Izd-vo AN SSSR, pp. 10-91. [Бобров Е.Г. 1957. Dipsacaceae. В кн.: Флора СССР, т. 24. Ред. Б.К. Шишкин, Е.Г. Бобров. Москва; Ленинград.: Изд-во АН CCCP, c. 10-91].

Bolikhovskaya N.S. 1981. Rastitelnost i klimat Srednego Pridnestrovya v pozdnem pleystotsene. Rezultaty palinologicheskogo analiza otlozheniy Kishlyanskogo Yara. In: Ketrosy. Musterskaya stoyanka na Srednem Dnestre. Moscow: Nauka, pp. 103-124. [Болиховская Н.C. 1981. Растительность и климат Среднего Приднестровья в позднем плейстоцене. Результаты палинологического анализа отложений Кишлянского Яра. В кн.:
Кетросы. Мустьерская стоянка на Среднем Днестре. Москва: Наука, с. 103-124].

Bolikhovskaya N.S. 1995. Evolyutsiya lessovo-pochvennoy formatsii Severnoy Evrazii. Moscow: Izd-vo Mosk. unta, 270 pp. [Болиховская Н.С. 1995. Эволюция лессово-почвенной формации Северной Евразии. Москва: Изд-во Моск. ун-та, 270 с.].

Bremer K., Backlund A., Sennblad B., Swenson U., Andreasen K., Hjertson M., Lundberg J., Backlund M., Bremer B. 2001. A phylogenetic analysis of $100+$ genera and $50+$ families of euasterids based on morphological and molecular data with notes on possible higher level morphological synapomorphies. Plant Systematics and Evolution, 229: 137-169.

Caputo P., Cozzolino S. 1994. A cladistic analysis of Dipsacaceae (Dipsacales). Plant Systematics and Evolution, 189: 41-61.

Caputo P., Cozzolino S., Moretti A. 2004. Molecular phylogenetics of Dipsacaceae reveals parallel trends in seed dispersal syndromes. Plant Systematics and Evolution, 246: 163-175.

Carlson S.E., Mayer V., Donoghue M.J. 2009. Phylogenetic relationships, taxonomy, and morphological evolution in Dipsacaceae (Dipsacales) inferred by DNA sequence data. Taxon, 58(4): 1075-1091.

Clarke G., Jones M.R. 1981. The Northwest European pollen flora. Dipsacaceae. Review of Palaeobotany and Palynology, 33: 1-25. [Reprinted in: The Northwest European pollen flora, vol. 3, parts 21-28. Eds W. Punt, G.C.S. Clarke. Amsterdam, etc.: Elsevier Sci. Publ. Company, pp. 21-25].

Donoghue M.J., Olmstead R.G., Smith J., Palmer J.D. 1992. Phylogenetic relationships of Dipsacales based on $r b c \mathrm{~L}$ sequences. Annals of the Missouri Botanical Garden, 79: $333-345$.

Erdtman G. 1952. Pollen morphology and plant taxonomy. Angiosperms. Stockholm: Almqvist \& Wiksell, 539 pp.

Faegri K., Iversen J. 1964. Textbook of pollen analysis. Oxford: Blackwell, 237 pp.

Gerasimenko N.P. 1997. Arkheologicheskiy almanakh. (Donetsk), 6: 3-64. [Герасименко Н.П. 1997. Природная среда обитания человека на юго-востоке Украины в позднеледниковье и голоцене (по материалам палеогеографического изучения археологических памятников). Археологический альманах (Донецк), 6: 3-64].

Gerasimenko N.P., Korzun Yu.L., Ridush B.T. 2014. Fizychna heohrafiya ta heomorfolohiya, 2(74): 68-74. [Герасименко Н.П., Корзун Ю.Л., Рідуш Б.Т. 2014. Природні зміни впродовж пізньольодовиків'я та голоцену у Середньому Припрутті (за даними палеонтологічного та літологічного вивчення відкладів печери Буковинка, зал Сухий). Фізична географія та геоморфологія, 2(74): 68-74].

Grichuk V.P. 1972. Osnovnye etapy istorii rastitelnosti yugo-zapada Russkoy ravniny v pozdnem pleystotsene. In: Palinologiya pleystotsena. Moscow: Nauka, pp. 9-53. 
[Гричук В.П. 1972. Основные этапы истории растительности юго-запада Русской равнины в позднем плейстоцене. В кн.: Палинология плейстоцена. Москва: Наука, с. 9-53].

Grichuk V.P. 1989. Istoriya flory i rastitelnosti Russkoy ravniny $v$ pleystotsene. Moscow: Nauka, 183 рр. [Гричук В.П. 1989. История флоры и растительности Русской равнины в плейстоцене. Москва: Наука, 183 с.].

Gubonina Z.P. 1975. Palinologicheskie issledovaniya osnovnykh gorizontov lessov $\mathrm{i}$ iskopaemykh pochv yuzhnoy chasti Russkoy ravniny. In: Problemy regionalnoy $i$ obshchey paleogeografii lessovykh i periglyatsialnykh oblastey. Moscow, pp. 43-59. [Губонина 3.П. 1975. Палинологические исследования основных горизонтов лессов и ископаемых почв южной части Русской равнины. В кн.: Проблемы региональной и общей палеогеографии лессовых и перигляциальных областей. Москва, c. 43-59].

Halbritter H. 2016. Dipsacus fullonum. In: PalDat - a palynological database. Available at: https://www.paldat. org/pub/Dipsacus_fullonum/301814 (Accessed 17 July 2018).

Halbritter H., Svojtka M. 2016. Dipsacus laciniatus. In: PalDat - a palynological database. Available at: https://www. paldat.org/pub/Dipsacus_laciniatus/301809 (Accessed 17 July 2018).

Kotov M.I. 1961. Dipsacaceae. In: Flora URSR, vol. 10. Ed. M.I. Kotov. Kyiv: Vyd-vo AN URSR, pp. 339-379. [Котов M.I. 1961. Dipsacaceae. У кн.: Флора УРСР, т. 10. Гол. ред. М.І. Котов. Київ: Вид-во АН УРСР, c. 339-379].

Kremenetskiy K.V. 1991. Paleoekologiya drevneyshikh zemledeltsev $i$ skotovodov Russkoy ravniny. Moscow: Nauka, 193 pp. [Кременецкий К.В. 1991. Палеоэкология древнейших земледельцев и скотоводов Русской равнины. Москва: Наука, 193 с.].

Kupriyanova L.A., Aleshina L.A. 1972. Pyltsa i spory rasteniy flory evropeyskoy chasti SSSR, vol. 1. Leningrad: Nauka, 170 рр. [Куприянова Л.А., Алешина Л.А. 1972. Пыльца и споры растений флоры европейской части СССР, т. 1. Ленинград: Наука, 170 с.].

Mabberley D.J. 1997. The plant-book: a portable dictionary of the vascular plants. $2^{\text {nd }}$ ed. Cambridge: Cambridge Univ. Press, $858 \mathrm{pp}$.

Moore P.D., Webb J.A. 1983. An illustrated guide to pollen analysis. London, etc.: Hodder and Stoughton, 133 pp.

Mostafa E.-N., Sedigheh N.-S., Rosa E. 2017. Pollen characters as taxonomic evidence in some species of Dipsacaceae from Iran. Bangladesh Journal of Plant Taxonomy, 24(2): 129-136.

Mosyakin S.L., Fedoronchuk M.M. 1999. Vascular plants of Ukraine. A nomenclatural checklist. Kiev, xxiii + 345 pp.

Pashkevich G.A. 1977. Palinologicheskoe issledovanie razreza stoyanki Korman IV. In: Mnogosloynaya paleoliticheskaya stoyanka Korman IV. Moscow: Nauka, pp. 105-111. [Пашкевич Г.А. 1977. Палинологическое исследование разреза стоянки Кормань IV.
В кн.: Многослойная палеолитическая стоянка Кормань IV. Москва: Наука, с. 105-111].

Pashkevich G.A. 1987. Palinologicheskaya kharakteristika otlozheniy mnogosloynoy stoyanki Molodova V. In: Mnogosloynaya paleoliticheskaya stoyanka Molodova V. Lyudi kamennogo veka $i$ okruzhayushchaya sreda. Moscow: Nauka, pp. 141-151. [Пашкевич Г.А. 1987. Палинологическая характеристика отложений многослойной стоянки Молодова V. В кн.: Многослойная палеолитическая стоянка Молодова V. Люди каменного века и окружающая среда. Москва: Наука, с. 141-151].

Perveen A., Qaiser M. 2011. Pollen flora of Pakistan. Dipsacaceae. Pakistan Journal of Botany, 43(6): 2825-2827.

Punt W., Hoen P.P., Blackmore S., Nilsson S., Le Thomas A. 2007. Glossary of pollen and spore terminology. $R e-$ view of Palaeobotany and Palynology, 143: 1-81. http:// doi.org/10.1016/j.revpalbo.2006.06.008

Reveal J.L. 2012. An outline of a classification scheme for extant flowering plants. Phytoneuron, 2012-37: 1-221. Avai-lable at: https://www.phytoneuron.net/PhytoNMagnoliidae.pdf

Simakova A.G., Puzachenko A.Yu. 2008. Rastitel'nost' $\mathrm{v}$ maksimal'noe poholodanie poslednego oledeneniya (LGM) $\quad(<=24.0->=17.0 \mathrm{kyr}$ BP $)$. In: Evolyutsiya ekosistem Evropy pri perekhode ot plejstotsena $k$ golotsenu (24-8 tys. l. n.). Eds A.K. Markova, T. Van Kol'fekhoten. Moscow: Tov. nauch. izd. KMK, pp. 315-341. [Симакова А.Г., Пузаченко А.Ю. 2008. Растительность в максимальное похолодание последнего оледенения (LGM) ( $<=24.0->=17.0 \mathrm{kyr}$ ВР). В кН.: Эволюция экосистем Европы при переходе от плейстоцена к голоцену (24-8 mыс. л. н.). Ред. А.К. Маркова, Т. Ван Кольфехотен. Москва: Тов. науч. изд. КМК, с. 315-341].

Sirenko E.A. 2017. Palinostratigrafiya kontinentalnikh verkhnepliotsenovykh-nizhneneopleystotsenovykh otlozheniy yuzhnoy chasti Vostochno-Evropeyskoy platformy. Ed. P.F. Gozhik. Kiev: Naukova Dumka, 166 pp. [Сиренко Е.А. 2017. Палиностратиграфия континентальных верхнеплиоценовых-нижненеоплейстоценовых отложений южной части Восточно-Европейской платформы. Ред. П.Ф. Гожик. Киев: Наукова думка, 166 с.].

Stuchlik L., Kvavadze E.V. 1995. On the problem of actuopalynology in the Carpathians and Caucasus. Acta Palaeobotanica, 35: 73-83.

Takhtajan A.L. 1987. Sistema magnoliofitov. Leningrad: Nauka, 439 рр. [Тахтаджян А.Л. 1987. Система магнолиофитов. Ленинград: Наука, 439 с.].

Takhtajan A.L. 1997. Diversity and classification of flowering plants. New York: Columbia Univ. Press, 663 pp.

Takhtajan A. 2009. Flowering Plants. Dordrecht: Springer, xlv+871 pp.https://doi.org/10.1007/978-1-4020-9609-9

Thiers B. 2008-onward (continuously updated). Index Herbariorum: A global directory of public herbaia and associated staff. New York Botanical Garden's Virtual Herbaium. Available at: http://sweetgum.nybg.org/science/ih/(Accessed 03 January 2019). 
Tokarev P.I. 2002. Morfologiya i ultrastruktura pyltsevykh zeren. Moscow: KMK Scientific Press, 51 pp. [Токарев П.И. 2002. Морфология и ультраструктура пыльцевых зерен. Москва: Т-во науч. изд. КМК, 51 с.].

Tsymbalyuk Z.M., Bezusko L.H. 2017a. Ukrainian Botanical Journal, 74(2): 122-130. [Цимбалюк 3.M., Безусько Л.Г. 2017а. Паліноморфологічні особливості представників роду Sambucus (Sambucaceae) Adoxaceae) флори України для цілей спорово-пилкового аналізу. Український ботанічний журнал, 74(2): 122-130]. http://doi.org/10.15407/ukrbotj74.02.122

Tsymbalyuk Z.M., Bezusko L.H. 2017b. Ukrainian Botanical Journal, 74(3): 224-232. [Цимбалюк 3.M., Безусько Л.Г. 2017b. Паліноморфологія видів роду Viburnum (Viburnaceae/Adoxaceae) флори України для цілей спорово-пилкового аналізу. Український ботанічний журнал, 74(3): 224-232]. https://doi. org/10.15407/ukrbotj74.03.203

Tsymbalyuk Z.M., Bezusko L.H. 2017c. Ukrainian Botanical Journal, 74(6): 539-547. [Цимбалюк 3.M., Безусько Л.Г. 2017с. Linnaea borealis (Caprifoliaceae) в Україні: паліноморфологічний та палеофлористичний аспекти. Український ботанічний журнал, 74(6): 539-547]. https://doi.org/10.15407/ukrbotj74.06.539

Tsymbalyuk Z.M., Bezusko L.H., Nitsenko L.M. 2018. Ukrainian Botanical Journal, 75(3): 248-259. [Цимбалюк 3.М., Безусько Л.Г., Ниценко Л.М. 2018. Паліноморфологічні особливості видів роду Knautia (Dipsacaceae): оцінка для цілей систематики та спорово-пилкового аналізу. Український ботанічний журнал, 75(3): 248-259]. https://doi.org/10.15407/ ukrbotj75.03.248
Tsymbalyuk Z.M., Mosyakin S.L. 2013. Atlas of pollen grains of representatives of Plantaginaceae and Scrophulariaceae. Kyiv: Nash Format, 276 pр. [Цимбалюк 3.M., Мосякін С.Л. 2013. Атлас пилкових зерен представників родин Plantaginaceae ma Scrophulariaceae. Київ: Наш формат, 276 с.]. https://doi.org/10.13140/ RG.2.2.16968.11527

Turland N.J., Wiersema J.H., Barrie F.R., Greuter W., Hawksworth D.L., Herendeen P.S., Knapp S., Kusber W.-H., Li D.-Z., Marhold K., May T.W., McNeill J., Monro A.M., Prado J., Price M.J., Smith G.F. (eds). 2018. International Code of Nomenclature for Algae, Fungi, and Plants (Shenzhen Code) adopted by the Nineteenth International Botanical Congress. Shenzhen, China, July 2017. Regnum Vegetabile, 159: i-xxxviii + 1-254. https://doi.org/10.12705/Code.201

Vinokurova L.V. 1959. Palinologicheskie dannye k sistematike semeystv Dipsacaceae i Morinaceae. In: Problemy botaniki, vol. 4. Moscow; Leningrad: Izdvo AN SSSR, pp. 51-67. [Винокурова Л.В. 1959. Палинологические данные к систематике семейств Dipsacaceaе и Morinaceae. В кн.: Проблемы ботаники, т. 4. Москва; Ленинград: Изд-во АН СССР, с. 51-67].

Zhang W.-H., Chen Z.-D., Li J.-H., Chen H.-B., Tang Y.C. 2003. Phylogeny of the Dipsacales s. 1. based on chloroplast trn L-F and $n d h \mathrm{~F}$ sequences. Molecular Phylogenetics and Evolution, 26: 176-189.

Zubets R.Ya. 1971. Ukrainian Botanical Journal, 28(2): 192-198. [Зубець Р.Я. 1971. Спорово-пилкові дослідження поверхневих шарів грунту степової частини України. Український ботанічний жсурнал, 28(2): 192-198].

Рекомендує до друку

Надійшла 25.01.2019 
https://doi.org/10.15407/ukrbotj76.01.024

\title{
Поширення в Україні Phallus hadriani (Phallales, Basidiomycota)
}

\author{
Василь П. ГЕЛЮТА \\ Інститут ботаніки ім. М.Г. Холодного НАН України \\ вул. Терещенківська 2, Київ 01004, Україна \\ vheluta@botany.kiev.ua
}

Heluta V.P. 2019. Distribution of Phallus hadriani (Phallales, Basidiomycota) in Ukraine. Ukrainian Botanical Journal, 76(1): 24-30.

M.G. Kholodny Institute of Botany, National Academy of Sciences of Ukraine

2 Tereschenkivska Str., Kyiv 01004, Ukraine

Abstract. The generalized information on the distribution of Phallus hadriani (Phallaceae, Basidiomycota) in Ukraine is provided. Earlier, the species was recorded in Cherkasy, Dnipropetrovsk, Kharkiv, Kherson, Kyiv, Odesa Regions and Kyiv city. In the article, new localities of the fungus were added from Vinnytsia, Volynska, Donetsk, Kirovohrad, Mykolaiv, Poltava and Transcarpathian Regions. At present it is a rather common species in Ukraine. This fungus is confined mainly to anthropogenically disturbed areas. Phallus hadriani occurs on various soils, namely, on sandy soils, including pure sand, gray or black soils. Usually it avoids areas with natural vegetation or humid and deeply shaded sites. Distribution patterns of the fungus indicate that in Ukraine it belongs to introduced species, and its range is gradually extending to the entire territory of the country. Obviously, over time this fungus will be found in all regions, except for the high Carpathian mountains. It is necessary to continue studying its distribution and dispersal. Due to application of $P$. hadriani in folk medicine, the fungus should be maintained in a pure culture in order to study its possible medicinal properties.

Keywords: alien species, distribution map, Ithyphallus, Phallaceae, Phallus imperialis

Гелюта В.П. 2019. Поширення в Україні Phallus hadriani (Phallales, Basidiomycota). Український ботанічний журнал, 76(1): 24-30.

Реферат. Подається узагальнена інформація про поширення в Україні Phallus hadriani (Phallaceae, Basidiomycota) гриба, для якого тут була відома незначна кількість місцезростань. Він вказувався лише для Дніпропетровської, Київської, Одеської, Харківської, Херсонської і Черкаської областей, а також для м. Києва. В цій статті значно поповнюються знання про поширення P. hadriani в Україні. До переліку вже відомих його локалітетів додані нові знахідки не тільки зі вказаних областей, а й з Вінницької, Волинської, Донецької, Закарпатської, Кіровоградської, Миколаївської та Полтавської. Кількість знахідок свідчить, що цей гриб в Україні є досить звичайним видом. Рhallus hadriani приурочений переважно до антропогенно порушених територій, трапляється на різних грунтах - піщаних, навіть на чистому піску, сірих, чорноземах, однак уникає ділянок з природною рослинністю або ж зволожених і сильно затінених. Особливості поширення гриба вказують на те, що він в Україні є заносним видом, ареал якого поступово охоплює всю територію держави. Очевидно, з часом цей гриб буде знайдений в усіх регіонах, за виключенням високогір'їв Карпат. Необхідно продовжувати вивчати його поширення. 3 огляду на застосування $P$. hadriani в народній медицині потрібно підтримувати його в чистій культурі з метою дослідження можливих цілющих властивостей.

Ключові слова: заносний вид, карта поширення, Ithyphallus Phallaceae, Phallus imperialis

Історія описання і подальшого дослідження Phallus hadriani Vent. (Phallaceae, Basidiomycota) докладно подана у статті О. Андерссона "Larger fungi on sandy grass heaths and sand dunes in Scandinavia" (Andersson, 1950). Цей гриб є одним 3 двох видів роду Phallus Junius ex L., відомих в Україні. Від близького до нього P. impudicus L. (incl. Dictyophora duplicata sensu auct.) відрізняється насамперед рожевим чи навіть фіолетовим кольором перидію плодового тіла (рис. 1) і ниток міцелію, значно слабшим й іншим запахом - останній неприємний солодкуватий, не

(C) В.П. ГЕЛЮТА, 2019 має нічого спільного з запахом гнилого м'яса. Якщо наявність $P$. impudicus можна відчути за сотні метрів, то запах $P$. hadriani виявляється лише за $0,5-1,0$ м до плодового тіла. Нерозкриті плодові тіла обох видів пахнуть приблизно однаково - нагадуючи аромат редьки. Ніжка P. hadriani переважно коротша, шапинка тупіша, отже він часто дещо відмінний від $P$. impudicus і за габітусом. До того ж, його плодові тіла часто утворюються у зростках не по одному, а до десяти штук. На розрізі закритих плодових тіл першого 3 них можна помітити, що стінки камер глеби розгалужені, довгі, інколи досягають внутрішнього шару перидію, тоді як у другого вони 
Рис. 1. Плодові тіла Phallus hadriani. A: на стадіï "яйця"; В: таке, що нещодавно розкрилося

Fig. 1. Fruit bodies of Phallus hadriani. A: at the "egg" stage; B: just opened one
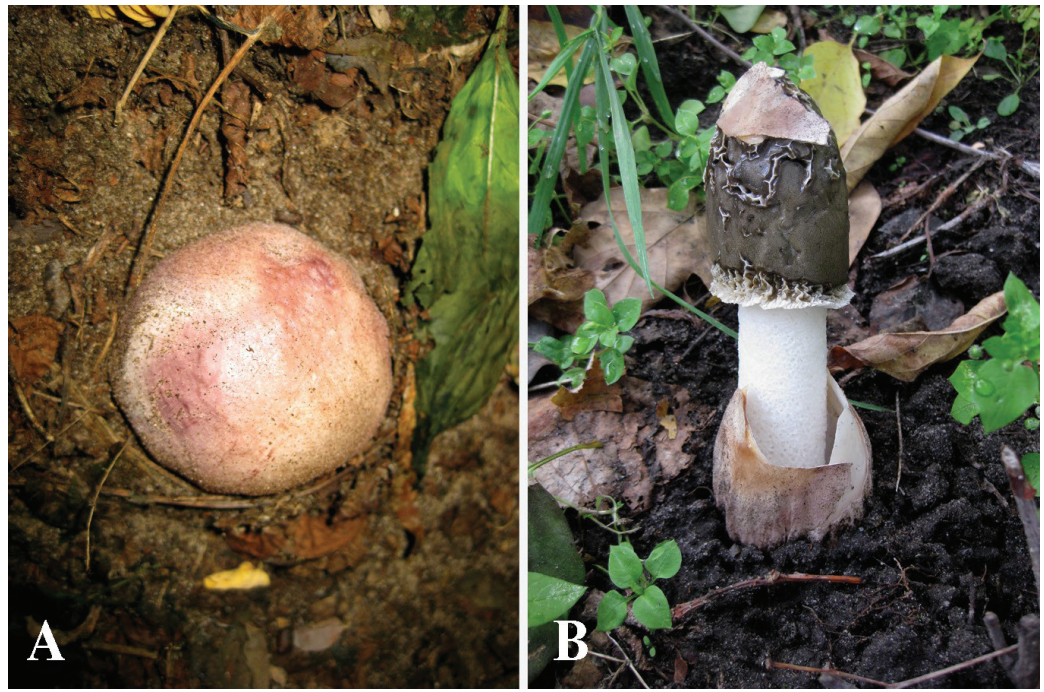

прості і досить короткі. Спори $P$. hadriani трохи менші, до $5 \times 2$ мкм (у P. impudicus - до 6,0 × 2,5 мкм).

Екологічно P. hadriani, особливо у скандинавських країнах, відносять до облігатних псамофілів (Høiland, 2006), проте у деяких працях вказується, що гриб зростає не тільки на пісках, а й на інших грунтах (Kreisel, 2001; Babenko, 2013; Ivoilov, 2014; Kour et al., 2016). Однак гриб, все ж таки, віддає перевагу піщаним грунтам чи майже чистим піскам, уникає затінених і вологих місць, через що його найчастіше знаходять у ксерофільних угрупованнях, часто на піщаних дюнах. Висловлюються здогадки, що цей вид може бути мікоризним грибом чи навіть паразитом на корінні рослин, або ж чистим сапротрофом, який розкладає залишки коренів та стовбурів (Andersson, 1950).

Phallus hadriani має досить широкий ареал, у межах якого трапляється спорадично i, як правило, у невеликій кількості. Він відомий в Європі (Австрія, Бельгія, Болгарія, Велика Британія, Данія, Естонія, Ірландія, Іспанія, Латвія, Литва, Македонія, Нідерланди, Німеччина, Норвегія, Польща, Португалія, Росія, Румунія, Словаччина, Угорщина, Франція, Чехія, Швейцарія, Швеція), Азії (Ізраїль, Індія, Китай, Пакистан, Росія (Республіка Тива), Туреччина, Японія), Африці (Канарські о-ви, Південноафриканська Республіка, Сейшельські о-ви), Північній Америці та в Австралії (куди, очевидно, був завезений 3 Европи на шепі, шо використовується в садівництві) (Josserand, 1948; Lange, 1949-1950; Andersson, 1950; Lazebniček, 1980; Vimba, 1997; Bedenko, 1978; Mazelaitis, 1978; Kreisel, 2001; Torp,
2002; Demirel, Uzun, 2004; Gothnier, Strid, 2004; Høiland, 2006; Karadelev et al., 2008; Brouwer et al., 2009; Friedrich, 2011; Moreno et al., 2013; Ivoilov, 2014; Domian et al., 2015; Kasuya et al., 2015; Lacheva, 2015; Fritz, 2016; Kour et al., 2016). У деяких країнах P. hadriani вважається видом, що перебуває під певною загрозою. Так, він включений в Червоний список грибів Болгарії (Lacheva, 2015), Червону книгу Латвії (Vimba, 1997); в Калінінградській обл. і Республіці Тива (Росія) цей макроміцет внесений в регіональні Червоні книги як рідкісний (Ivoilov, 2014). Наразі в Польщі він останнім часом виведений з-під охорони (Domian et al., 2015).

Інформація про поширення P. hadriani в Україні обмежена. О. Андерссон (Andersson, 1950) згадує, що А.А. Ячевський у 1911 р. наводив даний гриб (як P. imperialis Schulzer) з Бессарабії. Оскільки до Бессарабської губернії Росії на той час входили і деякі території сучасних Одеської та Чернівецької областей, не виключено, що це була перша реєстрація виду в Україні. На жаль, точніше сказати не можна, оскільки цю давню роботу А.А. Ячевського, опубліковану у Франції, не вдалося знайти*. Досить цікавим є повідомлення

* На той момент, коли цей номер журналу вже був готовим до друку, вдалося відшукати згадану статтю A.A. Ячевського (Jaczewski A. 1911. Note concernant des formes intéressantes d'Ityphyallus. Bulletin trimestriel de la Société mycologique de France, 27(1): 83-89). Автор повідомляє, що в 1907 р. він знайшов Ithyphallus imperialis Jacz. (= P. hadriani) у швейцарській колонії Шабо, неподалік від Аккермана (зараз с. Шабо БілгородДністровського р-ну Одеської обл.). Отже, P. hadriani відомий в Україні щонайменше з 1907 року. 


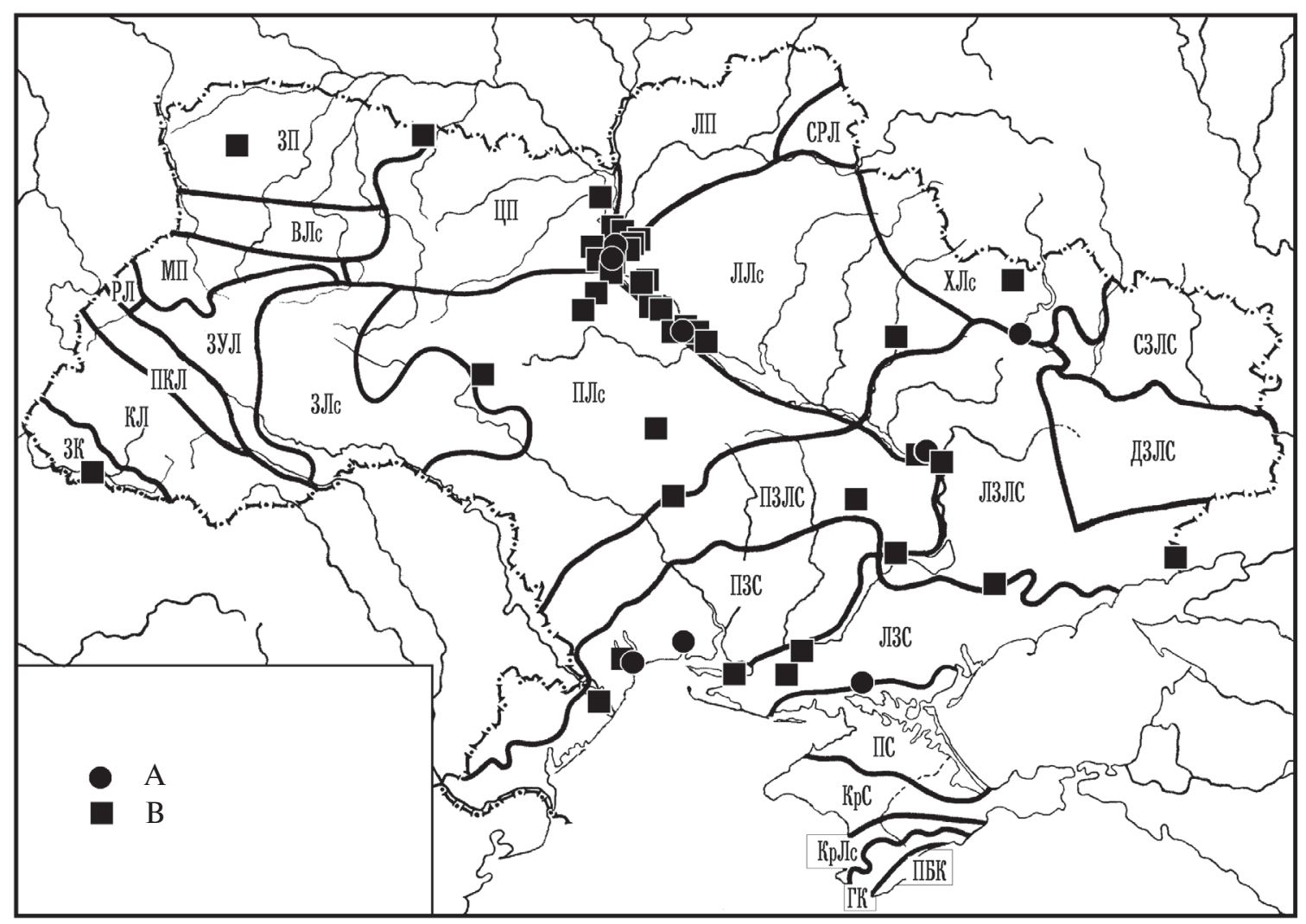

Рис. 2. Поширення Phallus hadriani на території України. А: літературні відомості; В: новіші додаткові відомості

Fig. 2. Distribution of Phallus hadriani in Ukraine. A: literature data; B: new records

3.Г. Лавітської (Lavitska, 1947) про виявлення Ithyphallus sp. у 1944 р. на околиці м. Канева Черкаської обл. Опис цього невизначеного виду, його екологічні особливості, без сумнівів, цілком збігаються 3 характеристиками $P$. hadriani. Тим більше, що пізніше в Каневі цей вид знаходять неодноразово (Dzhagan et al., 2008; Prudenko, Dzhagan, 2008; див. також наведений нами нижче список місцезнаходжень). Вважаємо, що серпень 1944 р. є часом першої достовірної реєстрації даного виду в Україні.

Протягом кількох десятиліть про P. hadriani в Україні не було жодних повідомлень. Лише у 1977 і 1978 pр. П.М. Корецький та О.А. Бакаєва знаходять його в Ботанічному саду ім. акад. О.В. Фоміна Київського національного університету імені Тараса Шевченка в закритому та відкритому грунті (Koretskyi, Bakayeva, 1979). Ми вперше виявили P. hadriani в липні 1978 р. в білоакацієвому лісі на південній околиці м. Білгород-Дністровського
(Одеська обл.), а потім, у серпні 1980 р., на порослому пирієм піску поблизу м. Буча Київської обл. На жаль, наукова інформація про згадані знахідки не публікувалася, однак про це повідомлялося в науково-популярному журналі "Юный натуралист" (Heluta, 1982). Мабуть, на той час даний вид все ж таки був досить рідкісним на території колишнього СРСР, оскільки реакції на цю статтю не було. Ще пізніше P. hadriani знаходили у Дніпропетровській (Dudka et al., 2009), Київській (Dubrovskyi et al., 2008), Одеській (Babenko, Tkachenko, 2012; Babenko, 2013), Харківській (Syvokon, 2008) та Черкаській (Prudenko et al., 2009) областях (рис. 2). Нам він трапився також у Києві, Волинській, Донецькій, Київській, Миколаївській, Херсонській та Черкаській областях. Зазначимо, що майже в усіх випадках гриб знаходили у невеликій кількості, однак у Врадіївському р-ні Миколаївської обл., у лісосмузі, створеній на чорноземі, ми виявили одразу понад 100 плодових тіл на різних стадіях їхнього розвитку. 
Phallus hadriani досить легко впізнається у природі завдяки кольору перидію плодових тіл (рис. 1). Така характерна ознака цього гриба унеможливлює помилку при його визначенні, отже для збору інформації про поширення виду можна користуватися відомостями, отриманими з електронних ресурсів та особистих повідомлень, особливо при наявності фотозображень. Нижче наводимо перелік усіх його місцезнаходжень, відомих на сьогодні на території країни, враховуючи літературні відомості (Lavitska, 1947; Koretskyi, Bakayeva, 1979; Dubrovskyi et al., 2008; Dzhagan et al., 2008; Prudenko, Dzhagan, 2008; Syvokon, 2008; Dudka et al., 2009; Prudenko et al., 2009; Babenko, Tkachenko, 2012; Babenko, 2013), підсумки перегляду матеріалів, що завантажуються мікологами-аматорами i просто грибниками на сторінки групи "Гриби України" в мережі Facebook (https://www.facebook.com/groups/Hryby. Ukrayiny/?ref=bookmarks), завдяки яким вдалося значно поповнити знання про поширення P. hadriani, особисті повідомлення (В.П. Гайова) і результати власних багаторічних спостережень.

Phallus hadriani Vent. Mém. Inst. Nat. Sci. Arts 1: 517. 1798

Syn.: Hymenophallus hadriani (Vent.) Nees, Syst. Pilze (Würzburg): 251. 1816 [1816-17]. - Phallus iosmos Berk., in Smith, Engl. Fl., Fungi (Ed. 2) (London) 5(2): 227. 1836. - Phallus imperialis Schulzer, in Kalchbrenner, Icon. Sel. Hymenomyc. Hung. (Budapest): 63, pl. 40, fig. 1. 1873. - Ithyphallus impudicus var. imperialis (Schulzer) De Toni, Syll. fung. (Abellini) 7(1): 8. 1888. - Ithyphallus impudicus var. iosmos (Berk.) De Toni, Syll. fung. (Abellini) 7(1): 9. 1888.

Нерозкриті плодові тіла спочатку напівкулясті, потім яйцеподібні, грушоподібні, напівзанурені у грунт, часто формуються зростками до десяти штук, прикріплені до субстрату міцеліальним коренеподібним шнуром, 3-6 см у діаметрі, 4-5 см заввишки, екзоперидій від гладкого до дещо бородавчастого, спочатку білуватий, потім рожевий, інколи до фіолетового. Міцеліальні шнури того ж кольору, що й екзоперидій. На розрізі видно, що сильно стиснуті ніжка (рецептакул) і голівка оточені шаром слизистої речовини, а стінки камер глеби галузяться, часто сягають стінки перидію. Розкрите плодове тіло 10-15 см заввишки, 3 білим циліндричним, до веретеноподібного порожнистим губчастим ніжкоподібним утвором (рецептакулом) та виповненою конічною білою сітчасто-ямчастою голівкою (шапинкою), вкритою глебою, спочатку майже не забарвленою, потім оливково-зеленою, желатиноподібною, ще пізніше - темно-оливковою та слизистою. Рецептакул 7-10 см завдовжки, 2-4 см завтовшки, пустотілий, губчастий, білий, при підсушуванні може жовтіти. Запах нерозкритого плодового тіла нагадує запах редьки, зрілого - порівняно слабкий, солодкуватий, трохи неприємний. Плодові тіла недовговічні, одно- чи дводенні. Спори жовтуваті, довгасті, до еліпсоїдних, гладенькі, (2,5-)3,0-4,0 $(-5,0) \times(0,8-) 1,5-2,0$ мкм. Базидія циліндрична, $15-20 \times 2,5-4,0$ мкм, 38 стеригмами й базальною пряжкою.

\section{Поширення в Україні}

Вінницька обл.: Липовецький р-н, с. Приборівка, 18.06.2016, О. Казакова.

Волинська обл.: м. Ковель, середина серпня 2006 р., М.П. Гелюта.

Дніпропетровська обл.: м. Дніпро, лівий берег, житловий масив Придніпровський, 07.06.2017, 08.11.2017, Н. Мельничук; м. Нікополь, 20.07.2018, В. Прішко; Петриківський р-н, ДніпровськоОрільський природний заповідник (Prydiuk, 2004; Dudka et al., 2009); смт Курилівка, близько до р. Дніпро, ліс, 08.07.2018, О. Капінус; там само, ближче до селища, ліс, 19.07.2018, О. Капінус; Софіївський р-н, с. Довгівка, 04.11.2018, Н. Марик.

Донецька обл.: Новоазовський р-н, заповідник "Хомутовський степ", садиба, зелене насадження, на грунті під кущами ліщини та бирючини, 04.06.2002, В.П. Гелюта.

Закарпатська обл.: Виноградівський р-н, смт Королево, 01.12.2012, 13.09.2014, В. Глеба.

Запорізька обл.: Токмацький р-н, поблизу с. Снігурівка, 28.10.2018, М. Кавун.

м. Київ: Голосіївський р-н, Конча-Заспа, 10.09.2017, І. Остапенко; Деснянський р-н, поблизу станції метро "Лісова", 14.07.2018, К. Федорова; Биківнянський ліс, 12.10.2017, Ю. Бикова; Лісовий масив, вул. Космонавта Волкова, 2, 2004 р., 3. Косинська; Дніпровський p-н, Воскресенський масив, бул. Перова, газон, 02.09.2018, М. Гавриленко-Хандешина; просп. Юрія Гагаріна, 23, сквер, А. Іщенко; Труханів острів, під дубом, 26.09.2018, Л. Приходченко; Оболонський p-н, вул. Героїв Дніпра, під абрикосом, 18.07.2018, 
Т.В. Гусак; північна околиця міста, 28.08.2016, А. Джос; Печерський р-н, вул. Липська, на газоні, під гіркокаштаном звичайним, 05.11.2017, Ю. Стецина; Святошинський р-н, Святошин, газон, 26.09.2018, Н. Майфат; Шевченківський р-н, Ботанічний сад ім. акад. О.В. Фоміна Київського національного університету імені Тараса Шевченка, в закритому грунті в дубовій бочці з Hibiscus rosa-sinensis L., жовтень 1976 і 1977 pp. (Koretskyi, Bakayeva, 1979); там само, відкритий грунт, під дубом, кленом, 17.08., 06.09., 14.09.1977, 29.06.1978, 27.07.1978, П.М. Корецький, О.А. Бакаєва (Koretskiy, Bakayeva, 1979); вул. Терещенківська 2, поблизу Інституту ботаніки, газон, серпень 2002 р., О.В. Лутченко, В.П. Гелюта.

Київська обл.: Бориспільський р-н, окол. с. Вороньків, ліс, 27.08.2018, 06.09.2018, Н. Дан; с. Дударків, лучна сінокосна ділянка на межі 3 культурним фітоценозом, серпень 2014 р., В.П. Гайова (понад 30 плодових тіл); с. Мирне, 27.08.2018, Н. Дан; м. Бровари, рудеральний фітоценоз, 12.09.2002, О.В. Лутченко; Броварський р-н, смт Вел. Димерка, серед щебеню, 11.08.2017, Ю. Литвинчук; Васильківський р-н, м. Васильків, 03.08.2018, О. Дерень; Вишгородський р-н, м. Вишгород, о-в Великий на Дніпрі (Dubrovskyi et al., 2008); між с. Лебедівка та c. Ровжі, берег Київського вдсх, 02.10.2004, С. Науменко; с. Пилява, Дніпровсько-Тетерівське лісомисливське господарство, 27.08.2016, Є. Руденко; с. Хотянівка, 14.10.2017, А. Агеєнко; Ірпінська міськрада, пн.-сх. окол. м. Буча, рудеральний фітоценоз, на піщаному грунті, серпень 1980 р., В.П. Гелюта; Миронівський р-н, зах. окол. с. Малий Букрин, дубовий ліс, 10.08.2004, В.П. Гелюта; Фастівський р-н, смт Кожанка, газон, рудеральний фітоценоз (під кущем Acernegundo L.), липень 1996 р., В.П. Гелюта.

Кіровоградська обл.: Маловисківський р-н, с. Хмельове, 02.11.2017, 3. Шевченко.

Миколаївська обл.: Врадіївський р-н, с. Новомиколаївське, лісосмуга, масово (понад 100 плодових тіл), 09.07.1982, В.П. Гелюта.

Одеська обл.: м. Білгород-Дністровський, південна околиця, білоакацієвий ліс, 03.07.1978, В.П. Гелюта, Л.І. Бурдюкова; Біляївський р-н, с. Алтестове, 22.09.2017, Н. Вовк; Комінтернівський р-н, РЛП "Тилігульський" (Babenko, Tkachenko, 2012); там само, степові схили, садова ділянка, квітень 2010 р., 09.05.2011, жовтень 2011 р.,
Ф.П. Ткаченко (Babenko, 2013); м. Одеса, Ботанічний сад Одеського національного університету імені I.I. Мечникова, 06.07.2012 (Babenko, 2013).

Полтавська обл.: м. Полтава, подвір'я школи, під кущами Spiraea sp. та Physocarpus opulifolius (L.) Maxim., 06.06, 30.07-02.08.2018, Т. Півень.

Харківська обл.: Зміївський р-н, с. Дачне, НПП "Гомільшанські ліси", насадження сосни на пісках, 20.10.2007 (Syvokon, 2008); м. Харків, вул. Валентинівська, 2, дендропарк ХНПУ імені Г.С. Сковороди, газон, 26.08, 29.08.2016, Ю. Бенгус.

Херсонська обл.: Голопристанський р-н, с. Буркути, 09.06.2012, 04.11.2012, Р. Степовий; Чорноморський біосферний заповідник, ІвановоРибальчанська ділянка, на пісках, 22-23.10.2006, В.П. Гелюта, М.М. Сухомлин, Ю.Я. Тихоненко; Олешківський р-н, смт Нова Маячка, насадження сосни, жовтень 2016 р., О. Мельник; Чаплинський p-н, Біосферний заповідник "Асканія-Нова" (Heluta, 1982; Dudka et al., 2009).

Черкаська обл.: Драбівський р-н, смт Драбів, 03.09.2017, К. Варення; Золотоніський p-н, с. Бубнівська Слобідка, ур. Склярове, піщана дорога, 2008 р. (Prudenko et al., 2009); Канівський р-н, окол. м. Канів, Канівський природний заповідник, садиба заповідника, алея з Caragana arborescens Lam. та на клумбі, 26.08.1944, 3.Г. Лавітська (Lavitska, 1947, як Ithyphallus sp.); там само, 23.09.2004 (Dzhagan et al., 2008); там само (Prudenko, Dzhagan, 2008); парк біля могили Т.Г. Шевченка, клумба, утрамбовані доріжки, 25.08.1944, 3.Г. Лавітська (Lavitska, 1947, як Ithyphallus sp.); м. Канів, город, серед капусти, 08.09.2002, С.О. Войтюк; поблизу Канева, лів. берег Дніпра, берег дренажного каналу, 04.01.2018, А. Проценко; РЛП "Трахтемирів", листяний ліс, край дороги, 19.06.2016, 3.О. Берест; там само, неподалік від нежилого с. Трахтемирів, дубовий ліс, 11.08.2004, В.П. Гелюта; там само, лісова дорога, 03.07.2010, В.П. Гелюта; Черкаський р-н, с. Білозір'я 11.09.2017, 10.10.2017, Т. Меренкова; м. Черкаси, вул. Гетьмана Сагайдачного, 12.11.2018, А. Лукава.

Як бачимо з наведених переліку локалітетів та карти (рис. 2), P. hadriani на сьогодні знайдений у більшості регіонів України, однак практично немає відомостей про його поширення на заході України (Волинський i Західний Лісостеп, Західноукраїнські, Карпатські, Прикарпатські та 
Розтоцькі ліси, Мале Полісся), на крайньому сході держави (Донецький та Старобільський злаковолучний Степи) та в Криму (Гірський Крим, Кримський Лісостеп, Кримський і Полиновий Степ та Південний берег Криму). В одній з праць O.B. Сивоконь (Syvokon, 2008) вказує, що гриб відомий в останньому з перелічених регіонів, але джерело цієї інформації не наводиться, і нам не вдалося його знайти.

Зазначимо, що за динамікою поширення в Україні $P$. hadriani дещо нагадує іншого представника поряду Phallales - Clathrus archeri (Berk.) Dring, якого спочатку вважали рідкісним і включили в Червону книгу України (Dudka, 2009), однак пізніше через його швидке розповсюдження, приуроченість до антропогенно змінених територій визнали звичайним і заносним видом у Карпатах і прикарпатських регіонах (Heluta, Zykova, 2018).

Спираючись на історію виявлення $P$. hadriani в Україні та поширення цього гриба переважно в значно змінених людиною оселищах, вважаємо його заносним видом, ареал якого поступово охоплює всю території держави. Очевидно, з часом він буде знайдений в усіх регіонах, за виключенням високогір'їв Карпат. Цей гриб навряд чи варто вважати рідкісним. 3 огляду на його застосування в народній медицині, потрібно підтримувати вид у чистій культурі з метою дослідження можливих його цілющих властивостей.

\section{Подяки}

Автор щиро вдячний усім грибникам-аматорам, які на сторінках групи "Гриби України" в мережі Facebook або ж особисто автору надали інформацію про нові місцезнаходження Phallus hadriani в Україні.

\section{СПИСОК ПОСИЛАНЬ}

Andersson O. 1950. Larger fungi on sandy grass heaths and sand dunes in Scandinavia. Botaniska Notiser. Supplement, 2(2): 1-89, pl. I-IX.

Babenko O.A. 2013. Ukrainian Botanical Journal, 70(5): 669-677. [Бабенко О.А. 2013. Епігейні гастероміцети Північно-Західного Причорномор'я. Український ботанічний журнал, 70(5): 669-677].

Babenko O.A., Tkachenko F.P. 2012. Biolohichnyi visnyk Melitopolskoho derzhavnoho pedagogichnoho universytetu, 2: 8-18. [Бабенко О.А., Ткаченко Ф.П. 2012. Макроміцети Регіонального ландшафтного парку "Тилігульський» (Одеська область). Біологічний вiсник Мелітопольського державного педагогічного університету, 2: 8-18].
Bedenko E.P. 1978. Mikologia i fitopatologia, 12(6): 469473. [Беденко Э.П. 1978. Гастеромицеты Белгородской области РСФСР. Микология и фитопатология, 12(6): 469-473].

Brouwer E., Braat M., van Hoek B., Noteboom R., Oplaat C., de Peijper R., Smits M., Klok P. 2009. WAD'N GEZWAM! De invloed van schelpenpaden op de paddenstoelendiversiteit van Terschelling. Coolia, 52(1): 7-17.

Demirel K., Uzun Y. 2004. Two new records of Phallales for the mycoflora of Turkey. Turkish Journal of Botany, 28: 213-14.

Dubrovskyi Yu.V., Dubrovska L.D., Kotenko A.H., Tytar V.M., Tsvelykh O.M. 2008. Zberezhennya ostroviv okolyts Kyyeva yak vazhlyvoi skladovoi dniprovskoho ekokorydoru. In: Dniprovskyi ekolohichnyi korydor. Kyiv: Wetlands international Black Sea Programme, pp. 7885. [Дубровський Ю.В., Дубровська Л.Д., Котенко А.Г., Титар В.М., Цвелих О.М. 2008. Збереження островів околиць Києва як важливої складової дніпровського екокоридору. В кн.: Дніпровський екологічний коридор. Київ: Wetlands international Black Sea Programme, c. 78-85].

Dudka I.O. 2009. Kvitokhvisnyk Archera, anturus Archera. Anthurus archeri (Berk.) Fischer. In: Chervona knyha Ukrainy. Roslynnyi svit (Red Data Book of Ukraine. Plant Kingdom). Ed. Ya.P. Didukh. Kyiv: Globalconsulting, p. 804. [Дудка I.O. 2009. Квітохвісник Арчера, антурус Арчера. Anthurus archeri (Berk.) Fischer. В кн.: Червона книга Украӥни. Рослинний світ. Ред. Я.П. Дідух. Київ: Глобалконсалтинг, с. 804].

Dudka I.O., Heluta V.P., Andrianova T.V., Hayova V.P., Tykhonenko Yu.Ya., Prydiuk M.P., Holubtsova Yu.I., Kryvomaz T.I., Dzhagan V.V., Leontyev D.V., Akulov O.Yu., Syvokon O.V. 2009. Hryby zapovidnykiv ta natsionalnykh pryrodnykh parkiv Livoberezhnoi Ukrainy, vol. 2. Kyiv: Aristey, 428 pp. [Дудка I.О., Гелюта В.П., Андріанова Т.В., Гайова В.П., Тихоненко Ю.Я., Придюк М.П., Голубцова Ю.І., Кривомаз Т.І., Джаган В.В., Леонтьєв Д.В., Акулов О.Ю., Сивоконь О.В. 2009. Гриби заповідників та національних природних парків Лівобережної України, т. 2. Київ: Арістей, 428 с.].

Dzhagan V.V., Prudenko M.M., Heluta V.P. 2008. Hryby Kanivskoho pryrodnoho zapovidnyka. Kyiv: Vydavnychopolihrafichnyi tsentr "Kyivskyi universytet", 271 pp. [Джаган В.В., Пруденко М.М., Гелюта В.П. 2008. Гриби Канівського природного заповідника. Київ: Видавничо-поліграфічний центр "Київський університет", 271 c.].

Friedrich S. 2011. New locations of threatened and protected Gasteromycetes s.l. in Northwestern Poland. Polish Journal of Environmental Studies, 20(3): 559-564.

Fritz Ö. 2016. Dynstinksvamp (Phallus hadriani) riklig i sanddyner i Alet vid Halmstad. Svensk Mykologisk Tidskrift, 37(2): 29-36].

Gothnier M., Strid T. 2004. Dynstinksvamp funnen i Sörmland - den svenska nordgränsen har flyttats. Svensk Mykologisk Tidskrift, 98: 274-277. 
Heluta V.P. 1982. Yunyi naturalist, 10: 36-37. [Гелюта В.П. 1982. Загадочный гриб-веселка. Юный натуралист, 10: 36-37].

Heluta V.P., Zykova M.O. 2018. Ukrainian Botanical Journal, 75(1): 137-142. [Гелюта В.П., Зикова М.О. 2018. Поширення в Україні Clathrus archeri (Phallales, Basidiomycota) - гриба, що має бути виключеним 3 Червоної книги України. Український ботанічний жсурнал, 75(1): 137-142].

Høiland K. 2006. Sand dune fungi on Lista (Vest-Agder, SW Norway) revisited after 33 years. Agarica, 26: 39-54.

Ivoilov A.V. 2014. Trudy Mordovskogo gosudarstvennogo prirodnogo zapovednika imeni P.G. Smidovicha, 12: 418421. [Ивойлов А.В. 2014. Phallus hadriani в Республике Мордовия. Труды Мордовского государственного природного заповедника имени П.Г. Смидовича, 12: 418-421].

Josserand M. 1948. Récolte de "Phallus imperialis Schulzer" dans la région ardéchoise. Bulletin mensuel de la Société linnéenne de Lyon, 17(1) : 6-7.

Karadelev M., Rusevska K., Stojkoska K. 2008. Distribution and ecology of the Gasteromycete fungi-orders Phallales and Sclerodermatales in the Republic of Macedonia. In: Proceedings of the III Congress of Ecologists of the Republic of Macedonia with International Participation, 06-09.10.2007, Struga. Special issues of Macedonian Ecological Society, vol. 8, pp. 208-216.

Kasuya T., Uchida A., Hosaka K. 2015. A new record of Phallus hadriani in the coastal dune of Eastern Hokkaido. Bulletin of the Shiretoko Museum, 37: 13-19.

Koretskiy P.M., Bakaeva E.A. 1979. Mikologia i fitopatologia, 12(6): 468-469. [Корецкий П.М., Бакаева Е.А. 1979. Гастеромицеты Ботанического сада им. акад. А.В. Фомина Киевского государственного университета им. Т.Г. Шевченко. Микология и фитопатология, 12(6): 468-469].

Kour H., Yanghol R., Kumar S., Sharma Y.P. 2016. Three species of Phallus (Basidiomycota: Agaricomycetes: Phallaceae) from Jammu \& Kashmir, India. Journal of Threatened Taxa, 8(1): 8403-8409.

Kreisel H. 2001. Checklist of the gasteral and secotioid Basidiomnycetes of Europe, Africa, and the Middle East. Österreichische Zeitschrift Pilzkunde, 10: 213-313.

Lacheva M. 2015. Fungal diversity in mediterranean and sub-mediterranean plant communities of Sakar Mountain. Trakia Journal of Sciences, 1: 18-26.

Lange M. 1949-1950. Bidrag til Dannmarks gasteromycetflora. Friesia, Nordisk Mykologisk Tidsskrift, 4(1-2): $66-71$.
Lavitska Z.H. 1947. Zbirnyk prats Kanivskoho bioheohraichnoho zapovidnyka, 1(3): 13-19. [Лавітська З.Г. 1947. Матеріали до флори Gasteromycetales Київщини. Збірник праць Канівського біогеографчного заповідника, 1(3): 13-19].

Lazebniček J. 1980. Nagygombák Csehszlovákia vegetációs öveiben. Mikológiai Közlemények, 3: 115-119.

Mazelaytis I.V. 1978. Микология и фитопатология, 12(4): 360-361. [Мазелайтис И.В. 1978. Охрана редких видов макромицетов. Микология и фитопатология, 12(4): 360-361].

Moreno G., Khalid A.N., Alvarado P., Kreisel H. 2013. Phallus hadriani and P. roseus from Pakistan. Mycotaxon, 125: 45-51.

Prudenko M.M, Dzhagan V.V. 2008. Zapovidna sprava $v$ Ukraini, 14(2): 11-14. [Пруденко М.М, Джаган В.В. 2008. Багаторічний моніторинг грибів у Канівському заповіднику. Заповідна справа в Україні, 14(2), c. 11-14].

Prudenko M.M., Dzhagan V.V., Vynohorodska O.S. 2009. In: Zberezhennya ta vidtvorennya bioriznomanittya pryrodnozapovidnykh terytoriy: materialy mizhnar. naukovoprakt. konf., prysvyachenoi 10-richchyu Rivnenskoho pryrodnoho zapovidnyka (m. Sarny, 11-13 chervnya 2009 roku). Rivne: VAT Rivnenska drukarnya, pp. 274-277. [Пруденко М.M, Джаган В.В., Виногородська О.С. 2009. Видовий склад та біотична приуроченість грибів деяких діючих та перспективних природно-заповідних об'єктів Середнього Придніпров'я. В зб.: Збереження та відтворення біорізноманіття природно-заповідних територій: Матер. міжнар. наук.практ. конф., присвяч. 10-річчю Рівненського природ. заповідника (м. Сарни, 11-13 червня 2009 р.). Рівне: ВАТ "Рівненська друкарня", с. 274-277].

Prydiuk N.P. 2004. Mikologia i fitopatologia, 38(6): 45-52. [Придюк Н.П. 2004. Базидиальные макромицеты Днепровско-Орельского природного заповедника. Микология и фитопатология, 38(6): 45-52].

Syvokon O.V. 2008. Zapovidna sprava v Ukraini, 14(2): 5662. [Сивоконь О.В. 2008. Гастероїдні базидіоміцети Національного природного парку "Гомільшанські ліси". Заповідна справа в Україні, 14(2): 56-62].

Torp E. 2002. Nogle planter i klitterne ved Grærup Strand. Flora og Fauna, 108(4): 95-99.

Vimba E. 1997. Mycological studies of the Latvian coast of the Baltic Sea and the Gulf of Riga. Proceedings of the Latvian Academy of Sciences. Natural Exact and Applied Sciences, 51(5-6): 234-40.

Рекомендує до друку

Надійшла 19.01.2019 
https://doi.org/10.15407/ukrbotj76.01.031

\title{
Сингенетичні зміни рудеральної рослинності Кривого Рогу
}

\author{
Наталія С. ЕРЕМЕНКО \\ Інститут ботаніки ім. М.Г. Холодного НАН України \\ вул. Терещенківська 2, Київ 01004, Україна \\ nathaly5755@gmail.com
}

Yeremenko N.S. 2019. Syngenetic changes of ruderal vegetation in Kryvyi Rih city. Ukrainian Botanical Journal, 76(1): 31-41.

M.G. Kholodny Institute of Botany, National Academy of Sciences of Ukraine

2 Tereschenkivska Str., Kyiv 01004, Ukraine

Abstract. The article presents results of the studies on syngenetic changes of the ruderal vegetation in Kryvyi Rih. The main directions of overgrowing in various types of ecotopes in the investigated territory are analyzed. The primary and secondary syngenetic vegetation changes are characterized. Features of the changes depending on the substrate character and anthropogenic influence are established. Restoration of vegetation is a long-term process. Ruderal communities in the city often undergo recurring disturbance; therefore, autogenic successions do not proceed. The major factors determining the species composition and overgrowing duration include adjacent vegetation and substrate. Syngenetic processes of ruderal vegetation in the city can be accelerated by management of the vegetation cover. All planned actions in ruderal ecotopes should be combined for simultaneous implementation of the optimization activities in all ruderal sites. Due to increasing transformed areas and weak cenotic relations between plants, the most actively overgrowing are adventive species with wide ecological amplitude (Acer negundo, Anisantha tectorum, Iva xanthiifolia, Grindelia squarrosa). Regular monitoring is required to reveal new adventive species and predict their further distribution.

Keywords: dynamics, successional series, syngenesis

Єременко Н.С. 2019. Сингенетичні зміни рудеральної рослинності Кривого Рогу. Український ботанічний журнал, 76(1): $31-41$.

Реферат. У статті висвітлено результати досліджень сингенетичних змін рудеральної рослинності Кривого Рогу. Проаналізовано основні напрями заростання різних екотопів досліджуваної території. Встановлено особливості протікання змін у залежності від типу субстрату й антропічного впливу. Відновлення рудеральної рослинності в регіоні є довготривалим процесом. На території міста рудеральні угруповання часто піддаються повторному порушенню, тому автогенні сукцесії не отримують розвитку. До провідних факторів, які визначають видовий склад та тривалість процесу заростання, належать: інтенсивність формування екотопу, прилегла рослинність та тип субстратів. Проведення заходів щодо управління розвитком рослинного покриву активізує сингенетичні зміни рудеральної рослинності в місті. Всі конструктивно-планувальні заходи в рудеральних екотопах мають бути об'єднані між собою в систему, що вимагає одночасного проведення оптимізаційних робіт у всіх іiї елементах (рудеральних місцях). З'ясовано, що у зв'язку зі збільшенням антропічно трансформованих територій і слабкістю ценотичних зв'язків між рослинами на цих ділянках активну участь у заростанні беруть адвентивні види з широкою екологічною амплітудою (Anisantha tectorum, Iva xanthiifolia, Grindelia squarrosa, Solidago canadensis). Постійний моніторинг є необхідним для виявлення нових адвентивних видів і прогнозування їхнього подальшого поширення в регіоні.

Ключові слова: динаміка, сингенез, сукцесійні ряди

\section{Вступ}

Значний антропічний вплив на урбоекосистему Кривого Рогу (Дніпропетровська обл.), виникнення низькопродуктивних ландшафтів, різноманітні порушення цілісності рослинного покриву та гостра необхідність розроблення підходів до управління його розвитком у досліджуваному регіоні зумовлюють актуальність всебічного вив-

(C) H.C. EPEMEHKO, 2019 чення змін, зокрема рудеральної рослинності, яка відзначається надмірною динамічністю. 3'ясування динаміки розвитку рудеральних угруповань дозволить скласти прогноз щодо темпів і спрямованості змін, проходження відновлювальних сукцесій, реакції ценозів на вплив тих чи інших факторів та допоможе розробити відповідні конструктивно-планувальні заходи 3 оптимізації даного типу організації рослинності. 
Заростання (сингенетичні зміни) є пусковим механізмом для майбутніх сукцесійних процесів, які визначають подальший розвиток рослинності через ряди або серії угруповань. Сингенез трактується як процес (сукцесія) та механізм (причина) формування рослинності (Kurochkina, Vuhkrer, 1987). Виникнення рослинності на нових субстратах розглядають як первинні антропічні сукцесії. Сингенез у вузькому розумінні є процесом заселення вільних місцезростань та зріджених угруповань рослинними організмами з утворенням рослинного покриву. Ценози, що формуються, проходять три стадії: піонерну (початкового ценозу), групово-заростеву (відкритого ценозу) та дифузну (закритого ценозу) (Shennikov, 1964). Піонерна є початковою стадією сингенетичних змін за відсутності між видами рослин істотних взаємовпливів. Групово-заростеві угруповання мають характер куртин. Дифузні - відрізняються більш-менш гомогенним розподілом популяцій.

За В.М. Сукачовим (Sukachev, 1954), сингенетичні зміни є першою стадією ендоекогенетичних. У регіоні досліджень вони часто уповільнюються повторною відсипкою субстрату або механічним порушенням едафотопу.

Сингенетичні процеси рудеральної рослинності міста Кривий Ріг вивчені досить повно лише на відвалах (Dobrovolskyi et al., 1979; Reva et al., 1993; Shanda, Malenko, 1996; Malenko, 2001; Khlyzina, 2004, 2008; Saforova, Reva, 2009; Yarkov, 2010, 2013; Pavlenko et al., 2017). Сингенез розглядається авторами як дискретний процес, у ході якого ценози розвиваються в напрямку формування зональних типів організації рослинності від рудеральних агломерацій 3 домінуванням піонерних видів рослин до угруповань 3 більш стійкими ценотичними зв'язками та пануванням багаторічних рослин переважно степового типу. Виявлена значна участь лігнозних видів у процесах природного заростання (Dobrovolskyi et al., 1979; Kharkhota, 1990; Korshikov, Krasnoshtan, 2012; Yarkov, 2013; Pavlenko et al., 2017). Первинними локалітетами їхнього формування є кам'янисті схили різних експозицій з домінуванням Robinia pseudoacacia L., Cerasus mahaleb (L.) Mill., Ulmus pumila L., Acer negundo L., Armeniaca vulgaris Lam., Elaeagnus angustifolia L., Populus deltoides Marshall. Деревна рослинність частіше розвивається в підніжжі схилів відвалів внаслідок сприятливих умов для іiї формування (вода або стікає до нижніх частин схилу, або просочується крізь кам'янисті примітивні грунти).

Рекультиваційні заходи на відвалах Криворіжжя розпочалися в 1961 р. і проводились переважно шляхом їхнього заліснення - штучного формування деревних насаджень. Вони не дали очікуваних результатів і прогнози заростання були реалізовані не повною мірою. На сьогодні площа штучно створеного рослинного покриву незначна і займає близько 10-15\% (300 га) загальної відвалів у регіоні. Відмічено, шо на плато відвалів, де зменшується зволоження, відбувається зниження асоційованості між деревостаном і травостоєм. Також спостерігається відмирання деревного ярусу та домінування зональних видів рослин, які за цих умов стають едифікаторами. На перших етапах рекультивації перевага надавалася формуванню деревно-чагарникових ценозів, у теперішній час комбінованим: лісовим і трав'яним (Smetana, Mazur, 2008; Yarkov, 2010). Як показали результати рекультивації та аналіз літератури, основним недоліком проведення оптимізації відвальних ландшафтів була недооцінка природних процесів заростання як відправного механізму майбутніх змін. Оскільки на відвалах із суглинистими та змішаними субстратами сингенетичні стадії проходять досить інтенсивно, проведення фіторекультиваційних заходів не є обов'язковим. Інколи це економічно невиправдано - так, наприклад, у результаті висівання злаків на скельних породах формуються розріджені, пригнічені сходи.

Як вже зазначалося, дослідження сингенетичних змін рослинності в інших рудеральних екотопах міста досі не проводилися. Не з'ясовані особливості заростання, сукцесійні ряди угруповань, не виявлені основні напрями та тривалість сингенетичних змін. Залишилися недослідженими провідні природні (екологічні) та антропічні фактори процесів заростання. Це, звичайно, суттєво знижує ефективність заходів 3 оптимізації та управління розвитком рослинності в рудеральних екотопах. Останні мають відповідати показникам успішності відновлення антропічно порушених екосистем, наведених Міжнародним товариством екологічної реставрації (International Society of Ecological Restoration): 1) подібність різноманіття й структури угруповання порівняно з рослинністю прилеглих територій; 2) наявність аборигенних видів; 3) інтеграція з ландшафтом; 
4) стійкість і саморегуляція ценозів (Hendrychová, 2008).

Мета даної роботи - проаналізувати сингенетичні зміни рудеральної рослинності Кривого Рогу, виявити їхні сукцесійні ряди, дослідити основні напрями процесів заростання та розробити заходи 3 оптимізації ценозів в умовах урбанізованого середовища.

\section{Матеріали та методи}

Для досліджень використали 1136 геоботанічних описів, здійснених автором у Кривому Розі впродовж 2016-2017 років і виконаних за методикою фітосоціологічної школи Ж. Браун-Бланке (Westhoff, van der Maarel, 1973). Площа описів складала від $4 \mathrm{~m}^{2}$ (обабіч доріг) до $100 \mathrm{~m}^{2}$ (на відвалах). База даних геоботанічних описів була створена за допомогою програмного забезпечення TURBOVEG 2.0 (Hennekens, 2009). Назви синтаксонів подані відповідно до Міжнародного кодексу фітосоціологічної номенклатури (Weber et al., 2000).

Дослідження процесів заростання проводилися на ключових ділянках за допомогою непрямих методів шляхом встановлення сукцесійних (часових) зв'язків на основі результатів вивчення просторових (еколого-ценотичних) рядів угруповань протягом 2016-2017 pp. (Aleksandrova, 1964). 3 метою з'ясування процесів сингенезу рудеральної рослинності були закладені моніто-рингові ділянки (див. рис. 1). Дослідження проводилися на хвостосховищі Центрального гірничо-збагачувального комбінату, відвалах ("Бурщицькому" НКГЗК, "Інгулецькому" ГВК), сміттєзвалищах побутових та будівельних відходів, насипах грунтів, ділянках сміттєзвалищ після спалювання та на пустирях. Уздовж залізничних шляхів досліджувалися верхні частини насипів, укоси та прилеглі до них ділянки, території поблизу станцій, ділянки між шпалами та запасні колії. Для визначення стадій сукцесії використовували метод ініціальних видів (Aleksandrova, 1964). Номенклатура таксонів наведена за чеклістом судинних рослин України (Mosyakin, Fedoronchuk, 1999).

\section{Результати та обговорення}

Первинний сингенез спостерігається при заростанні рослинами нової території (мілини річок, приморські дюни) (Aleksandrova, 1964). Такі зміни на території міста відбуваються на намитих ділянках хвостосховищ. Вторинний сингенез

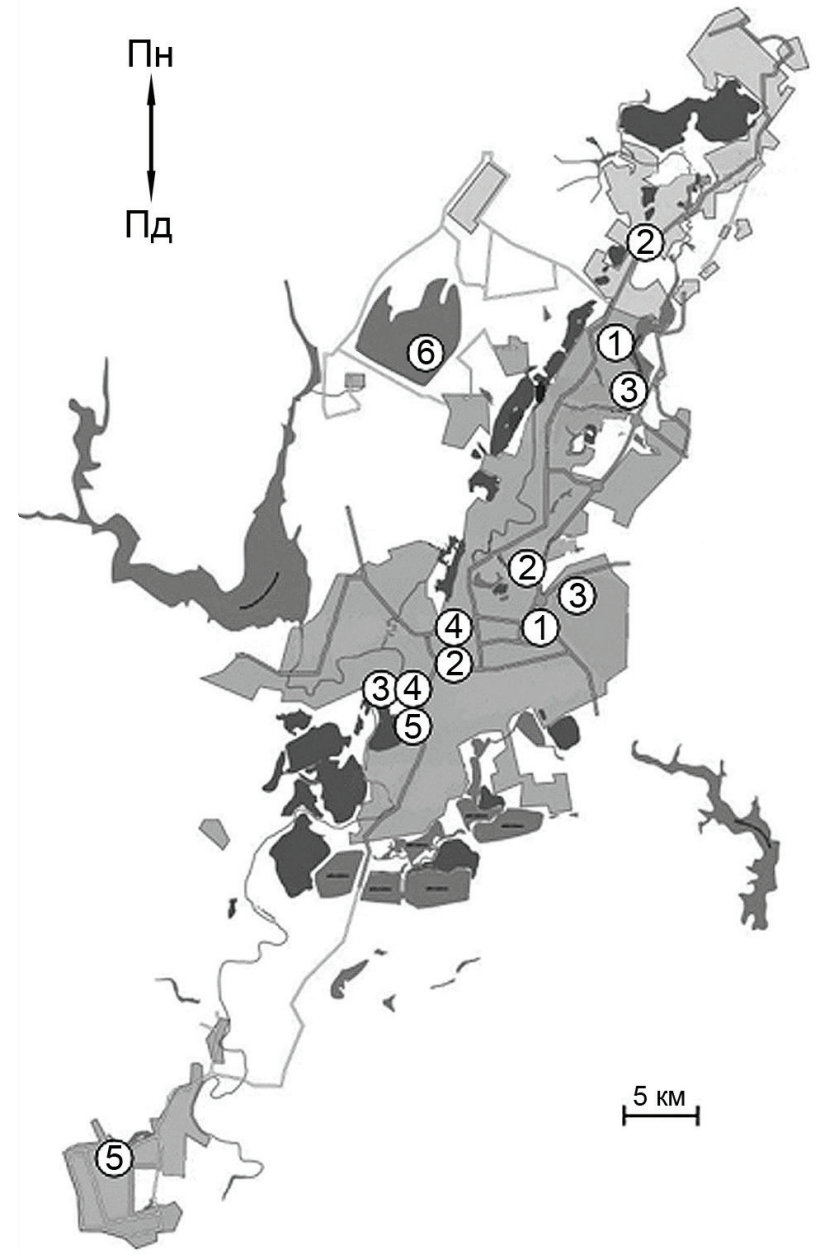

Рис. 1. Картосхема моніторингових ділянок заростання в Кривому Розі: 1 - новоутворені насипи; 2 - пустирі; 3 - залізничні насипи; 4 - сміттєві звалища; 5 - відвали; 6 - хвостосховище.

- техногенні екотопи, водосховища,

$=$ транспортні шляхи

Fig. 1. Schematic map of the plots of overgrowth in Kryvyi Rih: 1 - newly formed ecotopes; 2 - wastelands; 3 - railway embankments; 4 - rubbish dumps; 5 - iron ore dumps; 6 tailing pond.

- technogenous ecotopes, $\rightarrow$ reservoirs,
$=$ traffic roads

проходить на ділянках порушених екотопів внаслідок механічного пошкодження грунтового покриву, викошування рослин, на селітебних територіях, насипах грунту, залізничних насипах, сміттєвих звалищах, пустирях, відвалах. У Кривому Розі території, на яких відбуваються сингенетичні зміни, займають 5-7\% загальної площі міста. 
Процеси сингенезу постійно поновлюються обабіч доріг, на новоутворених ділянках унаслідок порушення цілісності грунтового покриву та відбуваються в напрямку відновлення угруповань. Відновлювальні сингенетичні зміни рослинності властиві переважно пустирям; спостерігаються вони також на сміттєвих звалищах, залізничних насипах та на будівельних майданчиках. Провідними факторами процесів заростання $€$ гідрорежим та інтенсивність формування екотопів. Ці зміни охоплюють стадії утворення несформованих угруповань та формування моной дидомінантних, які відповідають екологічним умовам місцезростань.

Первинний сингенез. Заростання намитих ділянок хвостосховищ. Хвостосховища - зони техногенезу, одні з найбільших за площею в місті, займають близько 70 км². Щорічно до них відкачується 15 млн куб. метрів засолених вод із кар'єрів та шахт (Smetana, 2002). Схили їхніх дамб складені із каміння, іноді рекультивовані з використанням чорнозему або суглинку. На території хвостосховищ грунти та рослинний покрив сформувались спонтанно по мірі відсипки ярусів дамби. Поверхня хвостосховищ заростає дуже повільно (декілька десятків років). Першими в сингенетичному ряді $\epsilon$ Ambrosia artemisiifolia L., Xanthium albinum (Widder) Scholz \& Sukopp, Bidens tripartita L. На субстратах 3 прошарками суглинків або глини, які затримують вологу, в заростанні значну участь бере Phragmites australis (Cav.) Trin. ex Steud. Сингенетичні процеси завершуються формуванням угруповань класу Stellarietea mediae Tx. et al. in Tx. 1950. Ініціальними видами наступних змін виступають Cirsium setosum (Willd.) Besser, Carduus acanthoides L., Melilotus albus Medik.

\section{Узагальнена схема заростання намитих ділянок хвостосховищ}

Phagmites austlalis community

Ambrosio artemisiifoliae-Xanthietum strumariae

Bidentetum tripartitae

1-2-й рік

Phagmites austlalis community

Bidentetum tripartitae

Ivaetum xanthiifoliae

Ambrosio artemisiifoliae-Xanthietum strumariae

$\rightarrow$ Ambrosio artemisiifoliae-Cirsietum setosi

3-4-й рік
Вторинний сингенез. Заростання насипів грунтів. Унаслідок ремонтних, будівельних та інших господарських робіт формуються насипи чорноземів на ділянках обабіч доріг, будівельних майданчиках переважно в центральній частині міста. Грунти $€$ рихлими, 3 недостатньою вологістю, іноді зі щебенем, займають незначні площі. Процеси заростання відбуваються досить швидко. Перша стадія (1-2 роки) відзначається формуванням рослинного покриву та домінуванням експлерентів - Amaranthus retroflexus L., Chenopodium album L., Setaria viridis (L.) P. Beauv., Portulaca oleracea L. Стадія завершується формуванням угруповань союзів Amarantho blitoidisEchinochloion crus-galli Solomakha 1988, PanicoSetarion Sissingh in Westhoff et al. 1946, PolygonoChenopodion Koch 1926, Eragrostion Tx. ex Oberd. 1954. 3 часом, у заростанні також беруть участь види однорічних рослин Atriplex tatarica L., Anisantha tectorum (L.) Nevski, Echinochloa crusgalli (L.) P.Beauv., Iva xanthiifolia Nutt., Lepidium ruderale L., Polygonum aviculare L. s. str. У ценози проникають багаторічники Elytrigia repens (L.) Nevski, Artemisia absinthium L., які, ймовірно, виступають ініціальними видами наступної стадії. На етапі дифузних угруповань домінують Elytrigia repens, Anisantha tectorum, Iva xanthiifolia, Melilotus albus, Atriplex tatarica (Arepeva, 2008).

\section{Узагальнена схема заростання насипів грунтів}

Amarantho retflexi-Echinochloetum cruss-galli

Amarantho retroflexi-Setarietum glaucae

Ambrosio artemisiifoliae-Chenopodietum albi

Portulacetum oleracei

$$
\text { 1-2-й рік }
$$

Amarantho retflexi-Echinochloetum cruss-galli

Convolvulo arvensis-Amaranthetum retroflexi

Ambrosio artemisiifoliae-Chenopodietum albi

Polygonetum arenastri

Atriplicetum tataricae

$\rightarrow$ Setario viridis-Erigeronetum canadensis

Anisantha tectorum community

Ivaetum xanthiifoliae

3-4-й рік

Заростання пустирів. Пустирі - це незабудовані або занедбані ділянки біля житлових масивів 3 деградованими чорноземними грунтами. На території міста розташовані нерівномірно, займають значні площі (1200 га). Грунти характеризуються 
підвищеним вмістом азоту та недостатнім вмістом вологи (Khmelev, Berezutskiy, 2001). Відновлення рослинності в таких екотопах розпочинається iз заростання піонерними видами рослин та формуванням агломерацій Ambrosia artemisiifolia, Chenopodium album, Polygonum aviculare, Conyza canadensis, Lactuca serriola L. У подальшому, на 3-4-й рік, формуються монодомінантні ценози групово-заростевого типу з Atriplex tatarica, Elytrigia repens, Melilotus albus, Iva xanthiifolia, Erysimum diffusum. Регіональною специфікою $є$ значна участь Poa angustifolia L. у ценозах початкових етапів (Lisogor, Bagrikova, 2015). Ініціальними видами наступної стадії сукцесії є багаторічники, зокрема Artemisia absinthium, Onopordum acanthium L., Achillea submillefolium Klokov \& Krytska. Сингенетичні процеси на пустирях біля житлових масивів у центральній частині Кривого Рогу завершуються формуванням Ivaetum xanthiifoliae, Atriplicetum tataricae, Melilotetum albi-officinalis Sissingh 1950 та Onopordetum acanthii Br.-B1. 1926. На віддалених від приватних секторів територіях описані Achilleo millefoliae-Grindelietum squarrosae Kostylev in Solomakha et al. 1992, Plantagini lanceolataeChondrilletum junceae Levon 1997, Agropyretum repentis Felföldy 1942, Tanaceto-Artemisietum vulgaris Br.-B1. (1931) 1949.

\section{Узагальнена схема заростання пустирів}

Ambrosio artemisiifoliae-Chenopodietum albi

Atriplicetum tataricae

Setario viridis-Erigeronetum canadensis

Erigeronto-Lactucetum serriolae

1-2-й рік

Cirsio-Lactucetum serriolae

Ambrosio artemisiifoliae-Chenopodietum albi

Atriplicetum tataricae

Erigeronto-Lactucetum serriolae

Ivaetum xanthiifoliae

Melilotetum albi-officinalis

$\rightarrow$ Onopordetum acanthii

Artemisia absinthium community

3-4-й рік

На пустирях відбувається часткове випалювання рослинності з метою управління їі розвитком або внаслідок самозаймання. Після випалювання процес відновлення протікає досить швидко (3-5 років). При цьому першими відновлюються ценози, сформовані за участі Elytrigia repens, Bromus hordeaceus L., B. squarrosus L., Poa angustifolia.
При порушенні субстрату внаслідок антропічних впливів (будівництво, витоптування, скидання побутових відходів) сингенетичні процеси блокуються, зупиняючись на початкових стадіях, це найчастіше спостерігається в центральній частині міста, де дія вказаних факторів є найінтенсивнішою. У зв'язку з низькою естетичною привабливістю домінантних видів Atriplex tatarica, Iva xanthiifolia, Melilotus albus та інших доцільно регулярно скошувати й проводити підсів злаків (Agropyron pectinatum (M.Bieb.) P.Beauv., Elytrigia intermedia (Host) Nevski, E. repens, Koeleria cristata (L.) Pers, Poa angustifolia, Festuca valesiaca Gaudin, Poa angustifolia L., Melica transsilvanica Schur.). Вселення видів класу FestucoBrometea Br.-B1. et Tx. ex Soy 1947 не призводить до витіснення рудеральних Artemisia absinthium, Carduus acanthoides, Melilotus albus, але послаблює їхні ценотичні позиції, відбувається поступова зміна флористичного складу. Домінантами в угрупованнях виступають злаки Elytrigia repens, Poa angustifolia, Bromus hordeaceus, асектаторами Falcaria vulgaris Bernh., Medicago romanica Prodan, Galium ruthenicum Willd., Potentilla arenaria Borkh. У подальшому на пустирях міста формуються осередки квазіприродної рослинності, які мають високу естетичну цінність, а також є джерелом діаспор. У випадку послаблення антропічного впливу сингенетичні процеси завершуються формуванням відносно стійких ценозів Convolvulo arvensis-Agropyrion repentis Görs 1966.

Заростання сміттєвих звалищ. Сміттєві звалища - гетерогенні субстрати, часто 3 екстремальними умовами виростання: насиченістю важкими металами, підвищенням температури тощо (Ishbirdina, Ishbirdin, 1992). Видовий склад цих місць відрізняється збідненістю та домінуванням видів адвентивних рослин (Kostylov, 1990; Protopopova, 1991). Смітники відіграють значну роль у натуралізації останніх. У місті виділяють санкціоновані й несанкціоновані звалища побутового сміття. Їх формують біля будівель, обабіч доріг, по берегах річок, у канавах, на пустирях. Амплітуда вмісту вологи в грунті достатньо велика - від недостатнього до середнього. Процеси заростання сміттєвих звалищ в основному є подібними. Першими в сукцесійному ряду на сміттєзвалищах побутових відходів є однорічні види рослин: Amaranthus retroflexus, Ambrosia artemisiifolia, Chenopodium album, Polygonum 
aviculare, Iva xanthiifolia, на санкціонованих на периферії виявлений також Grindelia squarrosa. Екологічна специфічність екотопів зумовлює низьку ценотичну різноманітність сукцесійних стадій. Заростання сміттєвих звалищ у місті відбувається лише до стадії формування мозаїчно розміщених моно- та дидомінантних угруповань за участі видів з широкою екологічною амплітудою (Ambrosia artemisiifolia, Atriplex sagittata Borkh., Iva xanthiifolia, Urtica dioica L., Artemisia vulgaris L., Sambucus nigra L.). Особливістю рослинності таких ділянок є значна роль ергазіофітів (Anethum graveolens L., Hesperis pycnotricha Borbás \& Degen., Parthenocissus quinquefolia (L.) Planch., Syringa vulgaris L.). На території міста часто трапляються звалища будівельного сміття. Характер заростання фрагментарний, оскільки види поселяються на ділянках 3 грунтовим покривом. Першими з'являються однорічні види - Chenopodium album, Setaria viridis, Ballota nigra. Формуються агломерації за участі Melilotus officinalis, M. albus, Artemisia absinthium, Pastinaca sativa L., Kochia scoparia (L.) Schrad., Atriplex sagittata.

\section{Узагальнена схема заростання сміттєвих звалищ}

Amaranthus retroflexus community

Ambrosia artemisiifolia +Iva xanthiifolia community

Ambrosia artemisiifolia + Atriplex sagittata community

Ambrosio artemisiifoliae-Chenopodietum albi

Polygonetum arenastri

Atriplicetum tataricae

Ballota nigra community

1-2-й рік

Amarantho retroflexi-Setarietum glaucae

Ambrosio artemisiifoliae-Chenopodietum albi

Polygonetum arenastri

Ivaetum xanthiifoliae

Atriplicetum tataricae

$\rightarrow$ Melilotus albus community

Kochietum densiflorae

3-4-й рік

Евтрофний характер ділянок стимулює зберігання в складі угруповань нітрофільних рудеральних видів, які мають високу конкурентоздатність та пригнічують вселення інших видів рослин. Швидкість сукцесій уповільнена, тому в угрупованнях тривалий час залишається без зміни їхній флористичний склад (Arepeva, 2013a). Отже, для оптимізації рослинності сміттєвих звалищ необхідно вирівнювати їхній рельєф i проводити скошування травостою 3 метою перешкоджання формуванню та поширенню діаспор. Перспективним напрямом є оптимізація сміттєзвалищ шляхом насипання технічного компосту та формування грунтового покриву 3 подальшим висіванням злаків.

У місті з метою зменшення об'ємів побутових відходів, особливо поблизу селітебних територій, проводять їхнє спалювання, що уповільнює процеси природного заростання сміттєвих звалищ. Тому, спалювання сміття має бути повністю заборонене. На таких територіях початкові стадії заростання розпочинаються із заселення вигорілих ділянок однорічними видами: Amaranthus retroflexus, Kochia scoparia, Polygonum aviculare, Chenopodium album, а згодом (через 4-5 років) формуються мозаїчно розташовані зарості Setaria glauca (L.) P.Beauv., Elytrigia repens, Iva xanthiifolia. На часі припинення формування несанкціонованих смітників.

Заростання залізничних насипів. Залізничні насипи - це гетерогенні технотопи з сухими, бідними на поживні речовини, субстратами. Забруднення поверхні нагаром і мазутом зменшує іiї відбивні властивості та призводить до значного нагрівання влітку (Brandes, 1983; Parfenov, 1985). Рослини зазнають також впливів сильних потоків повітря й періодичної нітрифікації стічними водами потягів. У специфічних умовах залізничних насипів формуються ценози з високою часткою адвентивних видів, склад яких постійно поповнюється. Ці ділянки відіграють важливу роль у їхньому поширенні (Arepeva, 2013b, 2017).

Початкові стадії заростання ділянок між шпалами представлені поодинокими рослинами: Ambrosia artemisiifolia, Eragrostis minor Host, Conyza canadensis, Lactuca serriola. На рихлих субстратах насипів виявлені Amaranthus retroflexus, Atriplex tatarica, Setaria viridis. У подальшому формуються агломеративні угруповання. На наступному етапі заростання - групово-заростевому виявлені Anisantha tectorum, Kochia scoparia, Berteroa incana (L.) DC., Melilotus officinalis, Melica transsilvanica, Achillea submillefolium, Artemisia austriaca Jacq., Lactuca serriola. В зв'язку 3 обробленням цих ділянок гербіцидами, вони постійно перебувають на першому етапі заростання. На запасних і занедбаних залізничних магістралях формуються монодомінантні угрупо- 
вання за участі Calamagrostis epigeios (L.) Roth, Bromopsis inermis (Leyss.) Holub, Acer negundo. Ценози з домінуванням Ambrosia artemisiifolia, не зважаючи на їхнє періодичне знищення, постійно присутні на запасних залізничних шляхах.

3 віддаленням від станції на схилах залізничних насипів збільшується видовий склад угруповань внаслідок менш інтенсивного впливу регулювання. Формуються ценози Melilotetum albo-officinalis, Achilleo millefoliae-Grindelietum squarrosae, TanacetoArtemisietum vulgaris Br.-B1. (1931) 1949. Сингенетичні процеси завершуються формуванням угруповань Agropyretum repentis, Convolvulo-Brometum inermis Eliáš 1979, Falcario vulgaris-Elytrigietum repentis T. Müller et Görs 1969 та $з$ домінуванням Acer negundo.

\section{Узагальнена схема заростання ділянок між коліями}

Erigeronto-Lactucetum serriolae

Setario viridis-Erigeronetum canadensis

Digitario sanguinalis-Eragrostietum minoris

Anisantho-Artemisietum austriacae

Ambrosia artemisiifolia community

Acer negundo community

Grindelia squarrosa community

1-2-й рік

Erigeronto-Lactucetum serriolae

Anisantho-Artemisietum austriacae

Melilotetum albo-officinalis

Bertoretum incanae

$\rightarrow$ Convolvulo-Brometum inermis

3-4-й рік

\section{Узагальнена схема заростання залізничних насипів}

Atriplicetum tataricae

Kochietum densiflorae

Ambrosio artemisiifoliae-Chenopodietum albi

Cardarietum drabae

$$
\text { 1-2-й рік }
$$

Ambrosio artemisiifoliae-Chenopodietum albi

Ivaetum xanthiifoliae

Kochietum densiflorae

$\rightarrow \quad 3-4-и ̆$ рiк

Загрозу ценотичному різноманіттю та безпеці транспорту становлять угруповання 3 домінуванням Acer negundo на залізничних насипах, які мають тенденцію до розширення площ. Актуальним
$€$ пошук ефективних засобів перешкоджання їхньому розвитку.

Заростання відвалів. Відвали - це вторинні неоекотопи, що формуються внаслідок промислово-індустріальної діяльності та не мають природних аналогів (Malenko, 2001). Їхнє заростання має певні особливості, які пов'язані $з$ мікрокліматом і фізико-хімічними властивостями субстратів, i впливом зонально-кліматичних умов регіону, що в сукупності зумовлюють екотопічний відбір видів рослин. На початкових етапах сингенезу в інтенсивності природного заростання відвалів значну роль відіграє субстратна приуроченість, але з часом вплив цього чинника послаблюється (Pavlenko et al., 2017). Сингенез рослинності відвалів, складених лесовидними суглинками та глинами, відбувається вже в перший рік відсипання з формування агломерацій піонерних видів рослин. Заростання кам'янистих відвалів (залізисті кварцити 3 домішкою сланців) відбувається повільно й розпочинається на 56-й рік після їхнього відсипання (Yeremenko, 2017a). Суттєвим фактором зміни видового багатства виступає наявність/відсутність прилеглих територій, вкритих природною рослинністю як джерело генетичного матеріалу.

У територіальній структурі рослинного покриву більшості відвалів Кривого Рогу значні площі займають агломеративні угруповання 3 домінуванням Grindelia squarrosa на щебенистих субстратах і Ambrosia artemisiifolia, Centaurea diffusa на схилах, відсипаних суглинками та змішаними субстратами. Загалом, визначені стадії заростання співпадають з такими, виділеними раніше (Pavlenko et al., 2017). Проте в межах одного відвалу часто розвиваються різні угруповання, що свідчить про неоднакову тривалість заростання різних частин. На відвалах Південного гірничо-збачувального комбінату на платоподібних вершинах розвиваються ценози з домінуванням Elytrigia repens та Centaurea diffusa, Achillea submillefolium, Melilotus albus і Artemisia absinthium, на порушених схилах Atriplex tatarica, A. sagittata, Iva xanthiifolia. На східних схилах поширені угруповання за участі Melilotus albus, Artemisia absinthium, Silene bupleuroides L., Gypsophila perfoliata L., G. paniculata L., Conyza canadensis i Gypsophila perfoliata.

Формування монодомінантних угруповань за участі Kochia scoparia на першій стадії заростання дало підставу вважати їх особливою кохійною 
фазою сингенезу на відвалах Кривого Рогу 3 кварцитовим субстратом (Dobrovolskyi et al., 1979; Reva et al., 1993; Pavlenko et al., 2017). Підтвержено цю початкову стадію, представлену угрупованнями Kochia scoparia 3 незначною участю Artemisia absinthium, Melilotus albus, Polygonum aviculare, Xeranthemum annиum на змішаних субстратах. Такі ценози мають постійний піонерний характер, зумовлений періодичним вирівнюванням субстрату.

Щільні зарості Melilotus albus і M. officinalis типові для проміжних стадій сингенезу відвалів. A.O. Павленко та iн. (Pavlenko et al., 2017) прогнозують на дрібнощебенистих субстратах формування ценозів з домінуванням Calamagrostis epigeios i, відповідно, подальшої куничникової стадії, що слід розглядати як прояв дії мікрокліматичних факторів. Ними виявлені мозаїчні вкраплення угруповань Calamagrostis epigeios серед заростей Melilotus albus i M. officinalis в мікрозападинах. Квазістепові угруповання з переважанням Festuca valesiaca, Koeleria cristata, Stipa capillata L. займають незначні площі (Pavlenko et al., 2017). На різних стадіях сингенезу виявлені популяції раритетних видів - Linaria biebersteinii Besser., Thymus dimorphus Klokov \& Des.-Shost., Valeriana stolonifera Czern. тощо. Встановлено, що відвальні екотопи слугують своєрідними рефугіумами для останніх, оскільки вони розвиваються на територіях, де ценотичний вплив не є визначальним (Yeremenko, 2017b).

На завершальних стадіях сингенезу на відвалах формуються угруповання, наближені до зональних. Очевидною є необхідність виділення цих територій з природною рослинністю як особливих і заборона їхньої рекультивації. Підтримуємо доцільність введення нової созологічної категорії - пам'ятка індустріального ландшафту для відвалів (Tyamin, 2012). Території 3 відновленим рослинним покривом і прилеглими об'єктами гірничої промисловості (відпрацьовані кар'єри, шахти, рудники) мають стати основою для створення ландшафтно-індустріальних парків in situ (Kazakov, Titov, 2007; Tyamin, 2012). Для визначення принципів розбудови ландшафтно-індустріальних парків необхідно проводити комплексну оцінку території та виявляти насамперед потенційно відновлювальні ділянки й місця 3 рослинним покривом за участі раритетних видів рослин. Останні повинні стати зоною, відвідування якої регулюється. На ділянках із спонтанними та штучно створеними деревними насадженнями можна розвивати лісопаркову зону масового відвідування 3 велодоріжками й оглядовими майданчиками. На територіях зі скельними породами, де практично неможливо сформувати рослинність, створити зону"місячного ландшафту". Серед рекомендацій - відсипання гірничих порід у відпрацьовані кар'єри. В центрі міста (біля мікрорайону "Макулан") спостерігається нарошування відвалів у висоту шляхом насипання кристалічних порід. Заростання на цих територіях відбуватиметься через 2-3 роки й протікатиме повільно. Тут мають обов'язково проводитися меліоративні заходи, зокрема рельєфне планування та відсипання грунтів.

Відновлення рослинності рудеральних місць $\epsilon$ довготривалим процесом. Його активізація можлива лише за умови проведення відповідних заходів. Як показали наші дослідження, на залізорудних відвалах біологічну рекультивацію необхідно проводити лише 3 урахуванням майбутніх процесів природного заростання (Yeremenko, 2017a). Це передбачає підбір видів, здатних витримувати жорсткі екологічні умови та конкуренцію. 3 цією метою А.I Мазур зі співавторами (Mazur et al., 2016) пропонують висаджувати Stipa lessingiana, S. ucrainica P.A.Smirn, Festuca valesiaca, Melica transsilvanica, Botriochloa ischaemum (L.) Keng, Medicago falcata L. agg., Hyssopus officinalis L., Melilotus albus i M. officinalis) (Mazur et al., 2016). За нашими спостереженнями, до цього списку слід додати Gypsophila perfoliata, Koeleria cristata, Elytrigia repens, Achillea submillefolium, Tussilago farfara L. i Securigera varia (L.) Lassen. Крім того, при проведенні конструктивноплануваних заходів у місті неприпустимо використовувати адвентивні види рослин

На пустирях у всіх районах необхідно проводити періодичне (2-5 разів на рік) викошування до стадії формування багаторічників, на територіях сміттєзвалищ - здійснювати вирівнювання їхньої поверхні. При оптимізації угруповань залізничних насипів увагу слід приділити перешкоджанню поширення Acer negundo.

Всі конструктивно-планувальні заходи в рудеральних екотопах мають бути об'єднані між собою в систему, що вимагатиме одночасного проведення оптимізаційних робіт у всіх її елементах (рудеральних місцях) (Smetana, 2006). Такі вимоги $є$ основою для забезпечення стабільного розвитку 
урболандшафтів та екологічного оздоровлення території.

\section{Висновки}

Головна роль у заростанні рудеральних екотопів міста належить трав'яним однорічним видамексплерентам, які формують моно-, рідше дидомінантні угруповання. Можливість вселення в піонерній фазі спільно з видами широкої екологічної амплітуди аборигенних раритетних видів є особливістю сингенезу як природного явища на відвалах.

До провідних факторів, які визначають видовий склад і тривалість процесу заростання, належать: інтенсивність формування субстратів, прилегла рослинність як джерело діаспор, тип субстрату. Найшвидше (за 2-4 роки) сингенетичні зміни відбуваються на деградованих чорноземах, пустирях, ділянках при будівництві, найдовше (декілька десятків років) - на намитих ділянках хвостосховищ та на відвалах, складених кварцитами та сланцями. Повторне складування відпрацьованих гірничих порід у відвали, порушення грунтового покриву внаслідок будівничих робіт, повторне скидання побутових відходів, випалювання рослинного покриву блокують зональну спрямованість розвитку рослинності та зумовлюють зворотні сукцесії. У сингенетичних процесах на пустирях, сміттєвих звалищах, відвалах, залізничних шляхах значну роль відіграють ценози за участю адвентивних видів (Acer negundo, Anisantha tectorum, Iva xanthiifolia, Grindelia squarrosa).

Невід'ємною частиною конструктивно-планувальних заходів розвитку рудеральної рослинності у місті Кривий Ріг є одночасне їхнє проведення в різних екотопах.

\section{СПИСОК ПОСИЛАНЬ}

Aleksandrova V.D. 1964. Dinamika rastitelnogo pokrova. In: Polevaya geobotanika, vol. 3. Leningrad: Nauka, pp. 300-450. [Александрова В.Д. 1964. Динамика растительного покрова. В кн.: Полевая геоботаника, т. 3. Ленинград: Наука, с. 300-450].

Arepeva L.A. 2008. Ekologo-floristicheskaya klassifikatsiya ruderalnoy rastitelnosti urbanizirovannykh territoriy Kurskoy oblasti: Cand. Sci. Diss. Abstract. Bryansk, 20 pp. [Арепьева Л.А. 2008. Эколого-флористическая классификация рудеральной растительности урбанизорованных территорий Курской области: автореф. дис. ... канд. біол. наук: спец. 03.00.05 "Ботаника". Брянск, 20 c.].
Arepeva L.A. 2013a. Uchenye zapiski: elektronnyi nauchnyi zhurnal Kurskogo gosudarstvennogo universiteta, 4(28): 34-41. [Арепьева Л.А. 2013а. Фитоценозы несанкционированных свалок на урбанизированных территориях Курской области. Уиеные записки: электронный научный журнал Курского государственного университета, 4(28): 34-41].

Arepeva L.A. 2013b. Izvestiya Samarskogo nauchnogo tsentra Rossiyskoy akademii nauk, 15(3): 695-699. [Арепьева Л.А. 2013b. Обзор растительных сообществ железнодорожных насыпей в городах Курской области. Известия Самарского научного центра РАН, 15(3): 695-699].

Arepeva L.A. 2017. The vegetation of railway embankments of the Kursk region. Vegetation of Russia, 30: 3-28.

Brandes D. 1983. Flora und Vegetation der Bahnhofe Mitteleuropas. Phytocoenologia, 11(1): 31-115.

Dobrovolskyi I.A., Shanda V.I., Hayeva N.V. 1979. Ukrainian Botanical Journal, 36(6): 524-527. [Добровольський І.А., Шанда В.І., Гаєва Н.В. 1979. Характер i напрямки сингенезису в техногенних екотопах Кривбасу. Український ботанічний журнал, 36(6): 524-527].

Hendrychová M. 2008. Reclamation success in post-mining landscapes in the Czech Republic: A review of pedological and biological studies. Journal of Landscape Studies, 1: 63-68.

Hennekens S. 2007. Turboveg for Windows. 1998-2007. Version 2. Wageningen: Inst. voor Bos en Natuur, 84 pp.

Kazakov V.L., Titov V.V. 2007. In: Industrialna spadshchyna v kulturi i landshafti: materialy Druhoi vseukr. nauk. konf., Kуiv, pp. 31-38. [Казаков В.Л., Тітов В.В. 2007. Теоретико-методологічні засади вивчення об'єктів індустріальної спадщини Кривбасу. В зб.: Індустріальна спадщина в культурі і ландшафті: матер. Другої всеукр. наук. конф. (Київ, 23-26 травня 2007 р.). Київ: ДАКККіM, с. 31-38].

Kharkhota A.I. 1990. In: Problemy ustoychivosti biologicheskikh sistem: materialy Vsesoyuz. shkoly. Sevastopol, pp. 416-417. [Хархота А.И. 1990. Становление и структурно-функциональные особенности растительных сообществ в техногенных экотопах. В сб.: Проблемы устойчивости биологических систем: матер. всесоюз. шк. (Севастополь, 15-20 окт. 1990 г.). Харьков, с. 416-417].

Khlyzina N.V. 2004. Gruntoznavstvo, 5(3-4): 63-69. [Хлизіна Н.В. 2004. Сингенез і літофільні угруповання та сукцесії в теоретичному висвітленні. Грунтознавство, 5(3-4): 63-69].

Khlyzina N.V. 2008. Gruntoznavstvo, 9(1-2): 79-86. [Хлизіна Н.В. 2008. Сукцесійні системи на субстратах гірських порід кар'єрно-відвальних урочищ Кривбасу. Грунтознавство, 9(1-2): 79-86].

Khmelev K.F., Berezutskiy M.A. 2001. Zhurnal obshchey biologii, 62(4): 339-351. [Хмелев К.Ф., Березуцкий М.А. 2001. Состояние и тенденции развития флоры антропогенно-трансформированных экосистем. Журнал общей биологии, 62(4): 339-351]. 
Korshikov I.I., Krasnoshtan O.V. 2012. Zhiznestoykost drevesnykh rasteniy na zhelezorudnykh otvalakh Krivorozhya. Donetsk, 280 pp. [Коршиков И.И., Красноштан О.В. 2012. Жизнестойкость древесных растений на железорудных отвалах Криворожья. Донецк, 280 c.].

Kostylov O.V. 1990. Ukrainian Botanical Journal, 55(1): 13-20. [Костильов О. В. 1990. Рудеральна рослинність України. Український ботанічний журнал, 5(1): 13-20].

Kurochkina L.Ya., Vukhrer V.V. 1987. Razvitie idey V.N. Sukachova o singeneze. In: Voprosy dinamiki biogeotsenozov. Chteniya pamyati akad. V.N. Sukacheva. Ed. N.A. Shilov. Moscow: Nauka, pp. 5-27. [Курочкина Л.Я., Вухрер В.В. 1987. Развитие идей В.Н. Сукачова о сингенезе. В кн.: Вопросы динамики биогеоценозов. Чтения памяти акад. В.Н. Сукачева. Отв. ред. Н.А. Шилов. Москва: Наука, с. 5-27].

Lisogor L.P., Bagrikova N.A. 2015. Izvestiya Orenburgskogo gosudarstvennogo agrarnogo universiteta, 4: 173-175. [Лисогор Л.П., Багрикова Н.А. 2015. Экологическая дифференциация растительного покрова залежей Правобережного степного Приднепровья на примере Бугско-Ингульского геоботанического округа. Известия Оренбургского государственного аграрного университета, 4: 173-175].

Malenko Ya.V. 2001. Peculiarities of taxonomical and ecological composition of plant communities of the dumps in South-Western Area of Kryvbas: Cand. Sci. Diss. Abstract. Dnipropetrovsk, Dnipropetrovs'k National University, 15 pp. [Маленко Я.В. 2001. Особливості таксономічного та екоморфічного складу рослинних угруповань відвалів південно-західної зони Кривбасу: автореф. дис. ... канд. біол. наук: спец. 03.00.16 "Екологія". Дніпропетровськ, Дніпропетровський національний університет, 15 с.].

Mazur A.Yu., Kucherevskyi V.V., Shol H.N., Baranets M.O., Sirenko T.V., Krasnoshtan O.V. 2015. Nauka innovatsii, 11(4): 41-52. [Мазур А.Ю., Кучеревський В.В., Шоль Г.Н., Баранець М.О., Сіренко Т.В., Красноштан О.В. 2015. Біотехнологія рекультивації залізорудних відвалів шляхом створення стійких трав'янистих рослинних угруповань. Наука та інновації, 11(4): 41-52].

Mosyakin S.L., Fedoronchuk M.M. 1999. Vascular plants of Ukraine. A nomenclatural checklist. Kiev, xxiii +345 pp.

Parfenov V.I., Kim G.A., Rykovskiy G.F. 1985. Antropogennye izmeneniya flory $i$ rastitelnosti Belorussii. Minsk: Nauka i tekhnika, 295 pр. [Парфенов, В.И., Ким Г.А., Рыковский Г.Ф. 1985. Антропогенные изменения флоры и растительности Белоруссии. Минск: Наука и техника, 295 с.].

Pavlenko A.O., Krasova O.O., Korshykov I.I. 2017. Ukrainian Botanical Journal, 74(4): 360-372. [Павленко А.О., Красова О.О., Коршиков I.I. 2017. Сингенетичні процеси на залізорудних відвалах північної частини Криворіжжя. Український ботанічний журнал, 74(4): 360-372].

Protopopova V.V. 1991. Sinantropnaya flora Ukrainy i puti ee razvitiya. Kiev: Naukova Dumka, 192 pр. [Протопопова В.В. 1991. Синантропная флора Украины и пути её развития. Киев: Наукова думка, 192 с.].

Reva S.V., Shanda V.I., Komisar I.O. 1993. Ukrainian Botanical Journal, 50(3): 58-65. [Рева С.В., Шанда В.I., Комісар I.О. 1993. Заселення вищими рослинами відвалів Криворізького басейну. Український ботанічний журнал, 50(3): 58-65].

Saforova H.S., Reva S.V. 2009. Visnyk Dnipropetrovskoho universytetu, 17(2): 87-94. [Сафонова Г.С., Рева С.В. 2009. Заселення вищими рослинами залізорудних відвалів Кривбасу. Вісник Дніпропетровського університету, 17(2): 87-94].

Shanda V.I. 1990. Aktualni problemy ekolohii roslynnoho svitu Ukrainy, 1: 9-11. [Шанда В.I. 1990. Феномен розвитку та стабільності в теорії охорони рослинного покриву. Актуальні проблеми екології рослинного світу України, 1: 9-11].

Shanda V.I., Malenko Ya.V. 1996. In: Zemelni resursy Ukrainy: rekultyvatsiya, ratsionalne vykorystannya ta zberezhennya: Materialy mizhnar. nauk. konf. Dnipropetrovsk, pp. 99-100. [Шанда В.І., Маленко Я.В. 1996. Проблематика фіторекультивації та сингенезу. В зб.: Земельні ресурси України: рекультивація, раціональне використання та збереження: Матеріали міжнар. наук. конф. Дніпропетровськ, с. 99-100].

Shennikov A.P. 1964. Vvedenie v geobotaniku. Leningrad: Izd-vo Leningrad. un-ta, 447 pp. [Шенников А.П. 1964. Введение в геоботанику. Ленинград: Изд-во Ленинград. ун-та, 447 с.].

Smetana M.H. 2002. Syntaksonomiya stepovoi ta ruderalnoi roslynnosti Kryvorizhzhya. Kryvyi Rih: I .B.I. Publ., 131 pp. [Сметана М.Г. 2002. Синтаксономія степової та рудеральної рослинності Криворіжжся. Кривий Ріг: Вид-во I.B.I., 131 с.].

Smetana S.M. 2006. Zelene kiltse Kryvorizhzhya yak chastyna ekolohichnoi merezhi Kryvbasu. Kryvyi Rih, 40 pp. [Сметана С.M. 2006. Зелене кільце Криворіжжя як частина екологічної мережсі Кривбасу. Кривий Ріг, 40 c.].

Smetana O.M., Mazur A.Yu. 2008. In: Problemy zberezhennia bioriznomanittia $v$ pryrodnykh ta tekhnogenno porushenykh ekosystemakh: Materialy nauk. konf. molodykh vchenykh. Kryvyi Rih: Vydav. Dim, pp. 8-14. [Сметана О.М., Мазур А.Ю. 2008. До теорії оптимізації порушених гірничими роботами земель. У зб.: Проблеми збереження біорізноманіття в природних та техногенно порушених екосистемах: Матеріали наук. конф. молод. вчених. Кривий Ріг: Видав. дім, с. 8-14].

Sukachev V.N. 1954. Voprosy botaniki, 1: 449-463. [Сукачев В.Н. 1954. Некоторые общие теоретические вопросы фитоценологии. Вопросы ботаники, 1: 449-463]. 
Tyamin M.Yu. 2012. Pratsi Tsentru pam'yatkoznavsta, 21: 17-31. [Тямін М.Ю. 2012. Наукові засади організації парків-музеїв індустріальної культури (скансенів). Праці Центру пам'яткознавста, 21: 17-31].

Weber H.E., Moravec J., Theurillat J.-P. 2000. International Code of Phytosociological Nomenclature. 3 ed. Journal of Vegetation Science, 11(5): 739-768.

Westhoff V., Maarel E. van der. 1973. The Braun-Blanquet approach. In: Handbook of vegetation science. Vol. 5. Ordination and classification of communities. The Hague, pp. 617-726.

Yarkov S.V. 2010. Syngenez roslynnykh uhrupovan u landshaftakh zon tekhogenezu: Cand. Sci. Diss. Abstract. Kyiv, 21 pp. [Ярков С.В. 2010. Сингенез рослинних угруповань у ландшафтах зон техногенезу: автореф. дис. ... канд. геогр. наук. Київ, 21 с.].

Yarkov S.V. 2013. Naukovi zapysky Ternopilskoho natsionalnoho pedahohichnoho universytetu. Serirs Geografiya, 2(35): 23-30. [Ярков С.В. 2013. Розвиток мішаних за субстратом 20-40-річних відвальних ландшафтів Криворіжжя. Наукові записки Тернопільського національного педагогічного університету. Серія Географія, 2(35): 23-30].
Yaroshenko P.D. 1969. Geobotanika. Moscow: Prosveshchenie, 200 pр. [Ярошенко П. Д. 1969. Геоботаника. Москва: Просвещение, 200 с.].

Yeremenko N.S. 2017a. In: Zapovidna sprava u Stepoviy zoni Ukrainy: Materialy Vseukr. nauk.-prakt. konf. in Urzuf. Kyiv, pp. 75-79. [Еременко Н.С. 2017а. Сингенез рослинності відвалів Кривбасу : особливості та рольраритетнихвидів. Укн.: ЗаповіднасправауСтеповій зоні України: Матеріали Всеукр. наук.-практ. конф. (с. Урзуф, 14-15 березня 2017 р.). Київ, с. 75-79].

Yeremenko N.S. 2017b. In: Rehionalni problemy vyvchennya $i$ zberezhennya bioriznomanittya: Materialy miznar. nauk. konf. Chernivtsi, pp. 39-41. [Еременко Н.С. 2017b. Залізорудні відвали Криворіжжя як рефугіуми раритетних видів. У зб.: Регіональні проблеми вивчення $i$ збереження біорізноманіття: Матеріали міжнар. наук. конф. (м. Чернівці, 5-6 жовтня 2017 р.). Чернівці, с. 39-41].

Рекомендує до друку

Надійшла 09.08.2018 
https://doi.org/10.15407/ukrbotj76.01.042

\title{
Фітоценотична характеристика угруповань із участю Amorpha fruticosa (Fabaceae) у Середньому Придніпров'ї (Україна)
}

\author{
Василь Л. ШЕВЧИК, Тарас В. ШЕВЧИК \\ ННЦ "Інститут біології та медицини" Київського національного університету імені Тараса Шевченка \\ вул. Володимирська 64, Київ 03680, Україна \\ shewol@ukr.net \\ tarshev@ukr.net
}

Shevchyk V.L., Shevchyk T.V. 2019. Phytocenotic characteristics of plant communities with Amorpha fruticosa (Fabaceae) in the Middle Dnipro area (Ukraine). Ukranian Botanical Journal, 76(1): 42-51.

Taras Shevchenko National University, NSC Institute of Biology and Medicine

64 Volodymyrska Str., Kyiv 03680, Ukraine

\begin{abstract}
Due to rapid spread and naturalization of Amorpha fruticosa in natural plant communities in the Middle Dnipro region, the phytocoenotic range of this invasive species was studied. This is necessary in order to predict its behavior, to identify the most vulnerable biotopes in relation to possible invasions of this species, and to prevent their negative consequences, in particular, transformation of the regionally important natural biotopes. Analysis of 120 geobotanical relevés of plants associations from the studied region that include Amorpha fruticosa was performed. These cenopopulations belong to 4 classes, 5 orders, 7 unions, 7 associations, and a single community of unidentified syntaxonomical status within Dicrano-Pinion union. Phragmition communis + Magnocaricion elatae + Molinatealia - Rubo caesi-Amorphion fruticosae - Salicion albae form the central part in the vegetation of this area. The outermost zone of the phytocoenotic range for Amorpha fruticosa in the floodplain is a xeromezophilous demutational succession series represented by the following syntaxonomical aggregations: Galietalia veri - Artemisio dniproicaeSalicion acutifoliae - Dicrano-Pinion. In these floodplain phytocenoses, Amorpha fruticosa is capable of regular reproduction of populations due to the presence of individuals of the juvenile age group in the herbaceous layer. Occurrence of Amorpha fruticosa in the communities of the classes Robinietea and Carpino-Fagetea can be regarded mostly as a residual effect of the use of this shrub in forestry. In these populations of Amorpha fruticosa almost no individuals of the juvenile age exist and therefore there is no prospect of an extended recovery in such biotopes.
\end{abstract}

Keywords: Amorpha fruticosa, Dnipro floodplain, ecological succession, invasive species, Phragmito-Magnocaricetea, Robinietea, Salicetea purpurea, Vaccinio-Piceetea

Шевчик В.Л, Шевчик Т.В. 2019. Фітоценотична характеристика угруповань із участю Amorpha fruticosa (Fabaceae) у Середньому Придніпров'ї (Україна). Украӥнський ботанічний журнал, 76(1): 42-51.

Резюме. Швидке поширення та натуралізація Amorpha fruticosa в фітоценозах природного походження на території Середнього Придніпров'я обумовлює потребу вивчення фітоценотичного діапазону цього виду. Це необхідно для прогнозу його поведінки, визначення найбільш вразливих біотопів щодо можливих інвазій цього виду та попередження їхніх негативних наслідків, зокрема, трансформації важливих в природоохоронному відношенні природних біотопів цього регіону. У результаті синтаксономічного аналізу 120 геоботанічних описів 3 території Середнього Придніпров'я за участі Amorpha fruticosa встановлена приналежність ценопопуляцій цього виду до 4 класів, 5 порядків, 7 союзів, 7 асоціацій та одного угруповання із невизначеним синтаксономічним статусом (в складі союзу Dicrano-Pinion). Центральною ланкою рослинності регіону є заплавний гігромезофільний демутаційно-сукцесійний ряд, представлений угрупованнями синтаксонів: Phragmition communis + Magnocaricion elatae + Molinietalia - Rubo caesi-Amorphion fruticosae - Salicion albae. Крайовою зоною фітоценотичного діапазону в умовах заплави для A. fruticosa $€$ ксеромезофільний демутаційно-сукцесійний ряд, представлений угрупованнями синтаксонів: Galietalia veri Artemisio dniproicae-Salicion acutifoliae - Dicrano-Pinion. У цих заплавних фітоценозах A. fruticosa спроможний до регулярного відтворення популяцій, що відображається в описах присутністю особин ювенільного віку у ярусі трав. Випадки зростання аморфи в угрупованнях класів Robinietea та Querco-Fagetea найчастіше є залишковим ефектом від застосування цього чагарника в лісовому господарстві. В цих ценопопуляціях у Amorpha fruticosa майже відсутні особини ювенільного віку, що свідчить про безперспективність розширеного відновлення в таких біотопах.

Ключові слова: заплава Дніпра, екологічні сукцесії, інвазійний вид, Amorpha fruticosa, Phragmito-Magnocaricetea, Robinietea, Salicetea purpurea, Vaccinio-Piceetea

() В.Л. ШЕВЧИК, Т.В. ШЕВЧИК, 2019 


\section{Ветуп}

Початок інтродукції Amorpha fruticosa L. на територію України наприкінці XIX століття та широке використання виду як фітомеліоративної породи в лісовому господарстві в середині XX століття спричинило спонтанне його поширення, швидкий ріст чисельності популяцій й розширення меж вторинного ареалу. На даний час у Середньому Придніпров'ї вид натуралізувався на значних площах і став фоновим на узбережжях акваторій Київського, Канівського, Кременчуцького, Дніпровського та Каховського водосховищ, у пригирлових частинах більшості правобережних та лівобережних приток Дніпра (Evtushenko, Ivan'ko, 2009; Karmyzova, 2014; Shevchyk et al., 2015).

Дослідження у регіонах, де $A$. fruticosa займає великі площі, вказують на високу адаптованість рослин до різних умов та велику швидкість експансії виду. Але наводяться неоднозначні оцінки як його екосистемної ролі у рослинному покриві, так і значення для господарства. Важливим для виживання популяцій A. fruticosa є висока холодостійкість рослин, здатність відновлювати надземну частину при регулярному iii знищенні вподовж багатьох років, а у випадку заносу насіння - швидко формувати нові осередки. Також значущим є формування життєздатного банку насіння в грунті та алелопатичний вплив на інші види рослин (Kelbel, 2012; Blagojević et al., 2014; Csiszer et al., 2014; Egoshyn, 2014). Висока швидкість росту забезпечує швидке поширення i формування заростей вздовж доріг, споруд, на сінокосах та пасовищах, в паркових насадженнях (Sarateanu et al., 2008; Evtushenko, Ivan'ko, 2009). Однією з особливостей синекологічного впливу на екосистемному рівні є те, що зарості $A$. fruticosa сприяють виживанню окремих видів дрібних ссавців та збільшенню чисельності особин нітрофільних однорічних видів рослин і, таким чином, спричинюють зміни балансу елементів в екосистемах (Ruzhilenko, 2002; Chauge, Fried, 2011). Водночас $A$. fruticosa визнається перспективною рослиною для виробництва кормів для худоби, "зелених" добрив та при рекультивації земель (Manuilova, 2005; De Haan et al., 2006).

Вивчення широти фітоценотичного діапазону виявило широкі можливості цього інвазійного виду зростати в біотопах порушених осокових та очеретяних боліт, гідрофільних заростей чагарників, заплавних лісів та рідше мезофільних широколистяних лісів Європи (Siebold, Fischer, 2008).

За результатами дослідження даного виду в умовах Присамарського біостаціонару (верхня частина Дніпровського водосховища) наводиться перелік біотопів (в системі EUNIS) із зростанням A. fruticosa. Тут вид опанував дуже широкий діапазон оселищ. Зокрема він зростає на градієнті від постійно зволожених (C1) та пересихаючих (C2-3) континентальних водойм до боліт (D), пасовищ та лук (E), прирічкових чагарникових заростей та лісів $(\mathrm{F})$, в угрупованнях різних типів лісової рослинності $(\mathrm{G})$, вторинних біотопах 3 екстенсивним характером використання (I) та біотопах інтенсивно експлуатованих ділянок (J) (Karmyzova, 2014). У Середньому Придніпров’ї цей вид за кілька десятиліть перетворився в потужного едифікатора рослинних угруповань на заплаві й таким чином став вПливати на стан рослинного покриву, хід відновлювальних процесів у ньому та негативно впливати на популяції аборигенних видів (Lyubchenko, 1987; Shevchyk et al., 2013, 2015). У ролі кондомінанта фітоценозів Канівського природного заповідника він відмічається вже з 1986 року. Зокрема за домінантним принципом були виділені дві асоціації Robinietum amorpho-elytrigiosum (intermedia) та Saliceto-Populetum amorphosum (fruticosa) (Lyubchenko, Bortnyak, 1986). Пізніше, в ході первинної інвентаризації рослинності Канівського природного заповідника на основі флористичної класифікації (Shevchyk et al., 1996) були виділені нові для науки синтаксони, в яких цей вид має високі константність та показники покриття. Слід визнати, що негативним моментом у згаданих синтаксономічних інтерпретаціях $є$ те, що вони зроблені на основі невеликої кількості описів із досить обмеженої за площею території заплави впродовж одного вегетаційного сезону. Як показує досвід флористичної класифікації, у таких разових "зрізах" заплавної рослинності часто в першу чергу відбиваються флуктуаційні особливості її стану за один рік. Звичайним заходом покращення таких синтаксономічних схем $є$ їхня корекція за рахунок описів із ширшої території в різні роки. Ми не маємо достатньої кількості описів, аби вдаватися до таких синтаксономічних корекцій, і тому користуємося наявними синтаксономічними рішеннями. Наразі ключовим геоботанічним питанням для вказаного регіону є 


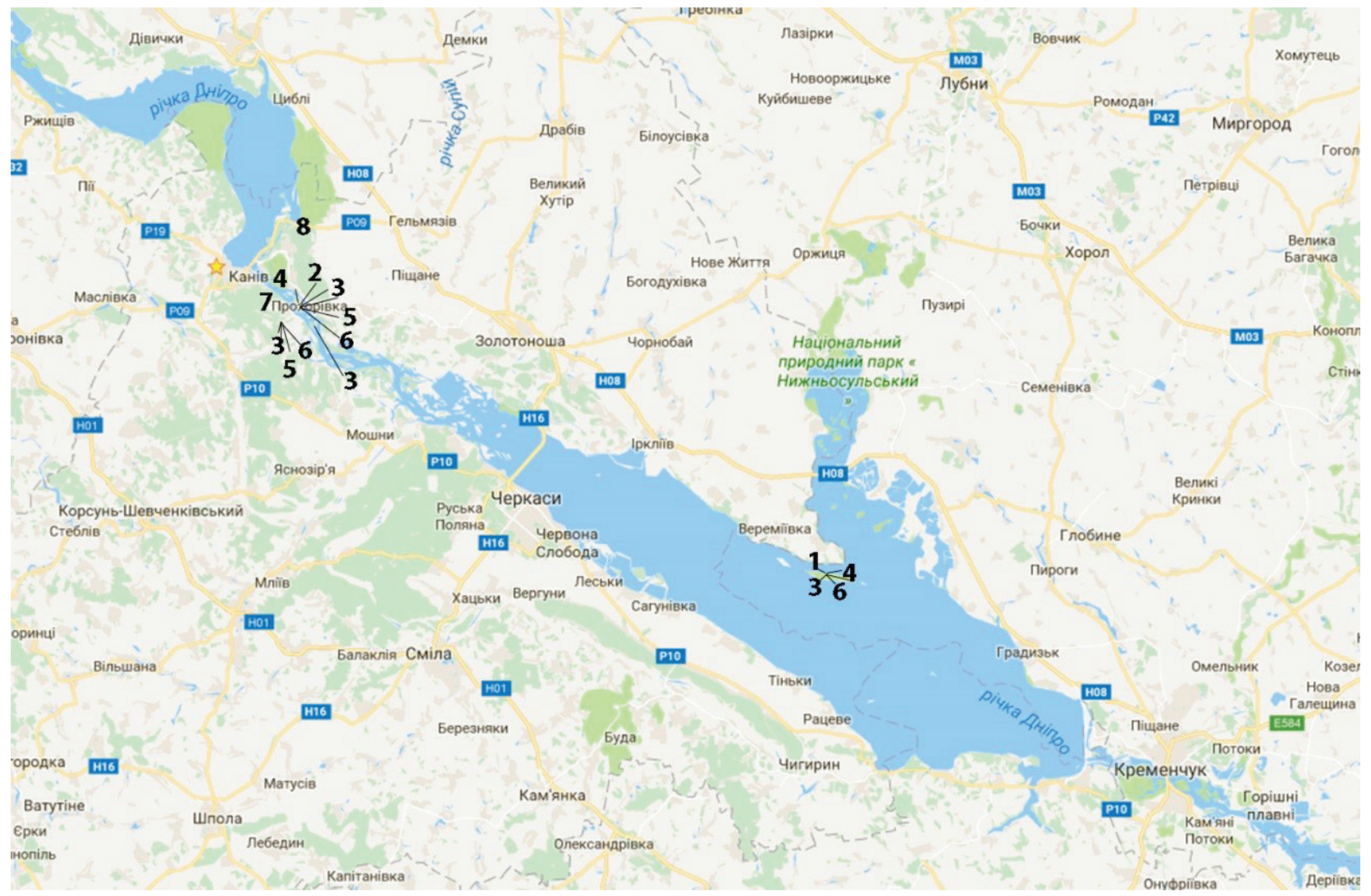

Рис. 1. Картосхема розміщення локалітетів виявлених синтаксонів (позначені цифрами) із участю Amorpha fruticosa. Цифрами позначені синтаксони: 1 - Acoretum calami; 2 - Caricetum acutiformis; 3 - Euphorbio virgultosae-Amorphaetum fruticosae; 4 - Artemisio dniproicae-Salicetum acutifoliae; 5 - Salici-Populetum; 6. Salicetum albae; 7 - Chelidonio-Robinietum; 8 - com. Amorpha fruticosa + Rubus

Fig. 1. Map of the recorded localities of syntaxa with Amorpha fruticosa. The syntaxa are indicated by numbers: $1-$ Acoretum calami; 2 - Caricetum acutiformis; 3 - Euphorbio virgultosae-Amorphaetum fruticosae; 4 - Artemisio dniproicae-Salicetum acutifoliae; 5 - Salici-Populetum; 6 - Salicetum albae; 7 - Chelidonio-Robinietum; 8 - com. Amorpha fruticosa + Rubus

виявлення сучасного фітоценотичного діапазону, сингенетичних властивостей і ценозоутворюючої ролі та прогнозу поведінки A. fruticosa на майбутнє.

\section{Матеріали та методи}

Було оброблено 120 повних геоботанічних описів, у виконанні 114 з яких, хоча б один із авторів брав особисту участь у фенологічно різні терміни впродовж 1995-2016 pp., 6 описів взято із літературних джерел (Kuzemko, Chorna, 2002).

Описи проводились на різних за розміром описових ділянках. Для опису угруповань лісової рослинності відбирали ділянки площею від 25 до $50 \mathrm{~m}^{2}$; для чагарникової від 5 до $10 \mathrm{~m}^{2}$. У ряді випадків в один опис зводились дані 3 кількох розрізнених дрібніших ділянок, але в межах однотипних фітоценозів. Описами охоплено більшість варіантів рослинних угруповань із участю $A$. fruticosa, що зустрічаються на геоморфологічно відмінних ділянках суходолу в межах двох водосховищ у середній течії Дніпра (рис. 1). Отримані матеріали оброблялися за методом Ж. Браун-Бланке способом перетворення фітоценотичних таблиць із використанням програми FICEN (Kosman et al., 1991; Sirenko, 1996) та подальшою обробкою в програмі Microsoft Excel. Синтаксономічна інтерпретація виділених фітоценонів здійснювалась 3 використанням інформації про діагностичні види синтаксонів у синтаксономічних зведеннях рослинності України (Solomakha, 2008), Польщі (Matuszkiewicz, 2001), Yexiï (Moraveč, 1995), Pociï (Mirkin, Naumova, 1998). Синтаксони високого та середнього ієрархічних рівнів ідентифікували з урахуванням зведення для всієї Європи (Mucina et al., 2016). Назви синтаксонів приводились відповідно до 
вимог Міжнародного кодексу фітосоціологічної номенклатури (Weber et al., 2000), назви рослин приводили за таксономічним зведенням (Mosyakin, Fedoronchuk, 1999). У синоптичній таблиці класи постійності розраховували лише для фітоценонів, виділених більше ніж за 5-ма описами з такою градацією шкали: трапляння менше $10 \%$ позначено +; 10-29\% - I ; 30-49\% - II ; 50-69\% - III; 70$89 \%$ - IV; трапляння більше $90 \%$ - V. В інших випадках оцінювали проективне покриття (ПП) видів з використанням наступної шкали: + позначено ПП виду менше 1\%, 1 - ПП 1-5\%, 2 $6-15 \%, 3-16-25 \%, 4-26-50 \%, 5-$ понад $51 \%$.

\section{Результати та обговорення}

На основі аналізу описів із участю $A$. fruticosa сформовано синоптичну таблицю та синтаксономічну схему.

\section{Синтаксономічна схема угруповань із участю Amorpha fruticosa}

Cl. Phragmito-Magnocaricetea Klika in Klika et Novak 1941

Ord. Phragmitetalia W. Koch 1926

All. Phragmition communis W. Koch 1926

Ass. 1 Acoretum calami Eggler 1933

Ord. Magnocaricetalia Pignatti 1953

All. Magnocaricion elatae (Br.-Bl. 1925) W. Koch 1926

Ass. 2 Caricetum acutiformis Soó 1928

Cl. Salicetea purpureae Moor 1958

Ord. Salicetalia purpureae Moor 1958

All. Rubo caesi-Amorphion fruticosae Shevchyk et V.Solomakha1996

Ass. 3 Euphorbio virgultosae-Amorphaetum fruticosae Shevchyk et V. Solomakha 1996

All. Artemisio dniproicae-Salicion acutifoliae Shevchyk et V. Solomakha 1996

Ass. 4 Artemisio dniproicae-Salicetum acutifoliae Shevchyk et V. Solomakha 1996

All. Salicion albae Soó 1930

Ass. 5 Salici-Populetum (Tüxen 1931) Meijer Drees 1936

Ass. 6 Salicetum albae Issler 1926

Cl. Robinietea Jurko ex Hadac et Sofron 1980

Ord. Chelidonio-Robinietalia Jurko ex Hadac et Sofron 1980

All. Chelidonio-Robinion Hadac et Sofron 1980

Ass. 7 Chelidonio-Robinietum Jurko 1963
Cl. Vaccinio-Piceetea Br.-Bl. in Br.-Bl., Siss. et Vlieger 1939

Ord. Pinetalia sylvestris Oberd. 1957

All. Dicrano-Pinion Matuszkiewicz 1962

8 - com. Amorpha fruticosa + Rubus

Загалом за присутності A. fruticosa в усіх представлених синтаксонах можна однозначно стверджувати про досить широкий його фітоценотичний діапазон (таблиця). Найгідрофільнішими біотопами, в які спроможні вселятися і подовгу зростати рослини A. fruticosa, є фітоценози класу Phragmito-Magnocaricetea. Зазвичай ініціальні стадії формування його популяцій в цих фітоценозах представлені невеликими ділянками у формі сегментів, що мають характер контагіозних смуг на стику угруповань прибережно-водної чи болотної рослинності і заростей $A$. fruticosa. Найчастіше спостерігаються в зоні хвильової абразії узбережжя, куди насіння A. fruticosa регулярно заноситься проточною водою та хвилями. На регулярно затоплюваних зниженнях внутрішньо-острівних ділянок заплави сприятливими для A. fruticosa виявляються локуси у стані активних дигресивно-демутаційних змін, спричинених низкою факторів (випасання, випалювання, пошкодження гризунами, руйнація дернини тваринами), що послаблюють дію основних едифікаторів угруповань класу PhragmitoMagnocaricetea та порядку Molinietalia.

Оскільки вибірка описів зроблена за ознакою присутності $A$. fruticosa і тому константність iї в усіх синтаксонах складає 100\%, то наближену оцінку фітоценотичного оптимуму адекватно робити лише за ознаками іiі проективного покриття. За цим показником очевидним $є$ те, що максимальну участь цей кущ відіграє в угрупованнях початкових стадій заростання чагарниковою та лісовою рослинністю безлісих вологих та свіжих ділянок заплави. В межах досліджуваного нами регіону такі ділянки займають достатньо велику частину заплави. Зовнішньо вони досить виразні і наразі на більшості заплавних островів верхньої частини Кременчуцького водосховища формують єдиний континуум площ довкола водойм і на регулярно затоплюваних зниженнях. Флористичний склад таких утворень досить строкатий, але характерною $€$ висока постійність та часте домінування діагностичних видів класу Salicetea purpureae. На наш погляд, їх слід відносити до окремого 
союзу Rubo caesi-Amorphion fruticosae. Більшість видів асоціації Euphorbio virgultosae-Amorphaetum fruticosae, включаючи й $A$. fruticosa та Rubus caesius L., мають досить широкий діапазон щодо режиму вологості грунту, і в межах цієї асоціації доцільно буде в майбутньому виділяти синтаксони рівня субасоціацій. $\mathrm{y}$ найвологіших екотопах фактично формуються зарості A. fruticosa на місці угруповань класу Phragmito-Magnocaricetea, а на більш піднятих ділянках центральної частини заплави у менше зволожених екотопах у складі іiі заростей вже зростає й Salix acutifolia Willd.

На дещо вищих за альтитудою поверхнях, складених крупнозернистими пісками, перевідкладеними вітром, що найчастіше зустрічаються в прирусловій, рідше в центральній частині заплави, на сухіших, рідко затоплюваних та бідніших грунтах, формуються розріджені й добре освітлені чагарникові зарості та рідколісся, в яких зі значно меншими показниками покриття також приймає участь $A$. fruticosa. Топографічно ці фітоценози мають характер невеликих плям-вкраплень, або поодиноких куртин із кущів, площею до кількох десятків квадратних метрів і знаходяться в оточенні угруповань остепнених псамофільних лук (порядок Galietalia veri Mirkin et Naumova 1986). Незначний едифікаторний вплив деревної рослинності визначає високу постійність в цих угрупованнях більшості видів порядку Galietalia veri, натомість наявність чагарникового та деревного ярусу не дозволяє такі угруповання віднести до цього порядку. Пропонуємо інтерпретацію для таких фітоценозів згідно з останніми європейськими ревізіями (Mucina et al., 2016), приведену в синтаксономічній схемі. Найсухіші, фактично не затоплювані, або дуже рідко і нетривало затоплювані повеневими водами, поверхні, що локалізуються переважно на приверхівкових ділянках піщаних підвищень у прирусловій частині заплави. Для них характерним є комплекс видів, що не витримують тривалого затоплення водою. Загалом, участь $A$. fruticosa в угрупованнях асоціації Artemisio dniproicae-Salicetum acutifoliae достатньо обмежена і тут вид втрачає позиції едифікатора. Занос насіння, ініціація та становлення популяцій в цих біотопах відбуваються в роки здосить високими і тривалими весняними повенями, як, наприклад, весною 2013 р. на Кременчуцькому водосховищі. Із закінченням будівництва Канівської ГЕС (1975 р.) таких високих повеней було лише кілька. Однорічні та дворічні сіянці у трав'яному ярусі, хоча й трапляються з високою постійністю, але масово всихають протягом другої половини літа. Лише одиничні з них за кілька сприятливих років можуть сягнути генеративного етапу розвитку. Окрім всього, насамперед на таких ділянках $A$. fruticosa часто страждає від пошкодження морозами, коли взимку тривалі відлиги чергуються із морозними періодами, як наприклад взимку 2015-2016 pp.

Amorpha fruticosa також має значну участь і у фітоценозах союзу Salicion albae, що представляють більш просунуту стадію ендоекогенезу молодої заплави. Із території Середнього Придніпров`я в складі цього союзу наводились описи нових асоціацій (Shevchyk et al., 1999), які в результаті критичного перегляду віднесені нами до двох асоціацій. Асоціація Salicetum albae об'єднує типові заплавні лісові фітоценози з домінуванням Salix alba L. та Populus nirga L. Окремі описи в межах цієї асоціації представляють похідні угруповання, в яких значну участь у деревостані беруть такі види, яК Acer negundo L., Morus nirga L., Ulmus laevis L., Pinus sylvestris L., Pyrus communis L. Найбільші площі таких лісів локалізуються на широких улоговинах та слабкопохилих поверхнях стоку в центральних частинах заплавних островів. Також ці ліси зростають на короткотривало затоплюваних поверхнях молодої заплави. Amorpha fruticosa в цих лісах формує розріджений чагарниковий ярус, з ПП 5-15\%, дуже рідко і на незначних площах воно становить до 50\%. Ще менші показники покриття для виду характерні в асоціації SaliciPopuletum, яка представляє найбільш просунуті стадії формування лісової рослинності на середньовікових ділянках заплави. Такий характер зміни іiі участі визначається, на нашу думку, значним зниженням освітленості в нижніх ярусах, через високі показники проективного покриття дерев та високорослих чагарників.

По надзаплавних терасах Середнього Придніпров'я випадки зростання A. fruticosa найчастіше пов'язані із використанням її як лісомеліоративної породи i наступним незначним спонтанним відтворенням популяцій на обмежених площах лише в місцях попереднього висаджування. Наведені раніше (Shevchyk, Solomakha, 1996) описи із лісових ділянок правого корінного берега Дніпра (четверта дислокована тераса правого берега Дніпра, або так звані "Канівські гори") представляють угруповання асоціації Chelidonio- 
Таблиця. Синоптична таблиця угруповань із участю Amorpha fruticosa у Середньому Придніпров ї Table. Synoptic table of the communities with Amorpha fruticosa in the Middle Dnipro area

\begin{tabular}{|c|c|c|c|c|c|c|c|c|c|c|}
\hline Номер синтаксону* & 1 & 2 & 3 & 4 & 5 & 6 & 7 & \multicolumn{3}{|c|}{8} \\
\hline $\begin{array}{l}\text { Середня кількість } \\
\text { видів в синтаксоні }\end{array}$ & 8 & 11 & 14 & 17 & 23 & 17 & 23 & 23 & 23 & 22 \\
\hline Кількість описів & 1 & 1 & 32 & 40 & 10 & 28 & 5 & 1 & 1 & 1 \\
\hline \multicolumn{11}{|c|}{ D. sp. cl. Phragmito-Magnocaricetea } \\
\hline Acorus calamus & 5 & - & - & - & - & - & - & - & - & - \\
\hline Lysimachia vulgaris & - & + & I & + & + & I & - & - & - & - \\
\hline Phragmites australis & 1 & - & $\mathrm{I}$ & - & - & $\mathrm{I}$ & - & - & - & - \\
\hline Carex acuta & + & - & II & - & - & II & - & - & - & - \\
\hline Carex acutiformis & - & 3 & + & - & - & + & - & - & - & - \\
\hline Lycopus exaltatus & - & + & $\mathrm{I}$ & - & - & $\mathrm{I}$ & - & - & - & - \\
\hline Carex riparia & 1 & - & + & - & - & - & - & - & - & - \\
\hline Lythrum salicaria & - & + & - & - & - & $\mathrm{I}$ & - & - & - & - \\
\hline Petasites spurius & - & - & + & - & - & $\mathrm{I}$ & - & - & - & - \\
\hline Rorippa amphibia & - & - & + & - & - & + & - & - & - & - \\
\hline Galium palustre & + & - & + & - & - & $\mathrm{I}$ & - & - & - & - \\
\hline Senecio tataricus & - & + & + & - & - & + & - & - & - & - \\
\hline Bidens frondosa & - & 1 & + & + & + & + & - & - & - & - \\
\hline Calystegia sepium & - & - & - & - & - & + & - & - & - & - \\
\hline Iris pseudacorus & - & - & + & + & + & $\mathrm{I}$ & - & - & - & - \\
\hline Leersia oryzoides & - & - & - & - & - & $\mathrm{I}$ & - & - & - & - \\
\hline Mentha aquatica & - & - & - & - & - & $\mathrm{I}$ & - & - & - & - \\
\hline \multicolumn{11}{|c|}{ D. sp cl. Salicetea purpurea } \\
\hline Amorpha fruticosa $(\mathrm{b})$ & + & 3 & $\mathrm{~V}$ & $\mathrm{~V}$ & $\mathrm{~V}$ & $\mathrm{~V}$ & $\mathrm{~V}$ & 1 & 1 & + \\
\hline Amorpha fruticosa (c) & + & 2 & III & $\mathrm{V}$ & II & III & - & + & + & + \\
\hline Acer negundo (a) & - & - & + & + & II & II & IV & - & - & - \\
\hline Acer negundo (b) & - & - & $\mathrm{I}$ & + & III & II & - & - & - & - \\
\hline Acer negundo (c) & - & - & $\mathrm{I}$ & $\mathrm{I}$ & + & II & - & - & - & - \\
\hline Populus nigra (a) & - & - & + & + & $\mathrm{I}$ & III & II & - & - & - \\
\hline Frangula alnus (b) & - & - & $\mathrm{I}$ & - & IV & $\mathrm{I}$ & - & + & 1 & + \\
\hline Salix alba (a) & - & - & + & + & $\mathrm{V}$ & IV & - & - & - & - \\
\hline Salix alba (b) & - & - & - & - & - & + & - & - & - & - \\
\hline Populus alba $(a)$ & - & - & + & + & III & $\mathrm{I}$ & - & - & - & - \\
\hline Salix acutifolia $(\mathrm{b})$ & - & - & II & III & - & $\mathrm{I}$ & - & - & - & - \\
\hline Rubus caesius & - & - & $\mathrm{V}$ & $\mathrm{I}$ & $\mathrm{V}$ & II & - & - & - & - \\
\hline Aristolochia clematitis & - & - & III & IV & $\mathrm{V}$ & II & - & - & - & - \\
\hline Humulus lupulus & - & - & $\mathrm{I}$ & - & III & II & - & - & - & - \\
\hline $\begin{array}{l}\text { Lysimachia } \\
\text { nummularia }\end{array}$ & + & - & III & I & $\mathrm{V}$ & II & - & - & - & - \\
\hline Glechoma hederacea & - & - & III & II & III & II & II & - & - & - \\
\hline Carex muricata & - & - & $\mathrm{I}$ & + & $\mathrm{I}$ & + & $\mathrm{I}$ & - & - & - \\
\hline Equisetum pratense & - & - & $\mathrm{I}$ & + & IV & $\mathrm{I}$ & - & - & - & - \\
\hline Scrophularia nodosa & - & - & + & - & $\mathrm{I}$ & + & - & - & - & - \\
\hline \multicolumn{11}{|l|}{ D. sp. cl. Robinietea } \\
\hline Geum urbanum & - & - & - & - & $\mathrm{I}$ & - & $\mathrm{V}$ & - & - & - \\
\hline Moehringia trinervia & - & - & + & - & - & + & IV & - & - & - \\
\hline Alliaria petiolata & - & - & - & - & - & - & IV & - & - & - \\
\hline Chelidonium majus & - & - & - & - & - & + & IV & - & + & - \\
\hline $\begin{array}{l}\text { Robinia pseudoacacia } \\
\text { (a) }\end{array}$ & - & - & - & - & - & - & III & - & - & - \\
\hline $\begin{array}{l}\text { Caragana arborescens } \\
\text { (b) }\end{array}$ & - & - & - & - & - & - & III & - & - & - \\
\hline
\end{tabular}

\begin{tabular}{|c|c|c|c|c|c|c|c|c|c|c|}
\hline Номер синтаксону* & 1 & 2 & 3 & 4 & 5 & 6 & 7 & \multicolumn{3}{|c|}{8} \\
\hline $\begin{array}{l}\text { Середня кількість } \\
\text { видів в синтаксоні }\end{array}$ & 8 & 11 & 14 & 17 & 23 & 17 & 23 & 23 & 23 & 22 \\
\hline Кількість описів & 1 & 1 & 32 & 40 & 10 & 28 & 5 & 1 & 1 & 1 \\
\hline $\begin{array}{l}\text { Chaerophyllum } \\
\text { temulum }\end{array}$ & - & - & - & + & III & + & III & - & - & - \\
\hline Urtica dioica & - & - & I & - & I & $\mathrm{I}$ & III & - & - & - \\
\hline Galium aparine & - & - & + & + & II & + & III & - & - & - \\
\hline $\begin{array}{l}\text { Geranium } \\
\text { robertianum }\end{array}$ & - & - & - & - & - & - & III & + & + & + \\
\hline Taraxacum officinale & - & - & + & - & I & $\mathrm{I}$ & III & - & - & - \\
\hline Torilis japonica & - & - & + & + & - & + & II & - & - & - \\
\hline Impatiens parviflora & - & - & - & - & - & - & II & - & - & - \\
\hline Myosotis sparsiflora & - & - & + & - & - & + & II & - & - & - \\
\hline $\begin{array}{l}\text { Robinia pseudoacacia } \\
\text { (b) }\end{array}$ & - & - & - & - & - & - & I & - & - & - \\
\hline $\begin{array}{l}\text { Sambucus racemosa } \\
\text { (b) }\end{array}$ & - & - & - & - & - & - & - & - & - & + \\
\hline Sambucus nigra (b) & - & - & - & - & - & - & $\mathrm{I}$ & - & - & - \\
\hline Ballota ruderalis & - & - & - & - & - & - & $\mathrm{I}$ & - & - & - \\
\hline Arabidopsis arenosa & - & - & - & - & - & - & I & - & - & - \\
\hline Cucubalus baccifer & - & - & + & - & - & - & - & - & - & - \\
\hline Geranium pusillum & - & - & - & - & - & - & I & - & - & - \\
\hline Leonurus cardiaca & - & - & - & - & - & - & I & - & - & - \\
\hline Fallopia dumetorum & - & - & + & + & - & + & - & - & + & - \\
\hline Melandrium album & - & - & - & - & - & - & $\mathrm{I}$ & - & + & - \\
\hline Stellaria media & - & - & - & - & - & - & $\mathrm{I}$ & - & - & - \\
\hline Viola arvensis & - & - & + & + & - & - & $\mathrm{I}$ & - & - & - \\
\hline \multicolumn{11}{|c|}{ D. sp. cl. Vaccinio-Piceetea } \\
\hline Pinus sylvestris (a) & - & - & - & + & - & $\mathrm{I}$ & $\mathrm{I}$ & 2 & 2 & 1 \\
\hline Pinus sylvestris (b) & - & - & - & + & - & $\mathrm{I}$ & - & - & - & - \\
\hline Convallaria majalis & - & - & - & - & $\mathrm{I}$ & + & - & + & + & + \\
\hline Dicranum rugosum & - & - & - & - & - & - & - & 1 & 1 & - \\
\hline Pleurosium schreberi & - & - & - & - & - & - & - & + & + & + \\
\hline Agrostis capillaris & - & - & - & - & - & - & - & + & + & + \\
\hline Rubus sp. & - & - & - & - & - & - & - & 5 & 1 & 5 \\
\hline Populus tremula (a) & - & - & - & - & III & I & - & - & - & + \\
\hline Betula pendula (a) & - & - & - & - & - & $\mathrm{I}$ & $\mathrm{I}$ & - & - & + \\
\hline Betula pendula (b) & - & - & - & - & - & $\mathrm{I}$ & - & + & + & - \\
\hline $\begin{array}{l}\text { Campanula } \\
\text { rotundifolia }\end{array}$ & - & - & - & - & - & - & III & - & - & - \\
\hline $\begin{array}{l}\text { Polygonatum } \\
\text { odoratum }\end{array}$ & - & - & - & - & - & - & - & + & - & - \\
\hline Pyrola rotundifolia & - & - & - & - & - & + & - & - & - & - \\
\hline $\begin{array}{l}\text { Peucedanum } \\
\text { oreoselinum }\end{array}$ & - & - & - & - & - & - & - & + & - & + \\
\hline Veronica officinalis & - & - & - & - & - & - & - & + & + & - \\
\hline \multicolumn{11}{|c|}{ D. sp. cl. Carpino-Fagetea sylvaticae } \\
\hline Fraxinus excelsior $(\mathrm{c})$ & - & - & - & - & - & + & $\mathrm{V}$ & - & - & - \\
\hline Quercus robur (a) & - & - & - & + & IV & - & III & - & - & - \\
\hline Quercus robur $(\mathrm{b})$ & - & - & + & + & - & $\mathrm{I}$ & - & 1 & 3 & + \\
\hline Ulmus glabra & - & - & + & - & IV & + & - & - & - & - \\
\hline Pyrus communis (a) & - & - & - & + & $\mathrm{I}$ & + & III & - & - & - \\
\hline
\end{tabular}




\begin{tabular}{|c|c|c|c|c|c|c|c|c|c|c|}
\hline Номер синтаксону* & 1 & 2 & 3 & 4 & 5 & 6 & 7 & \multicolumn{3}{|c|}{8} \\
\hline $\begin{array}{l}\text { Середня кількість } \\
\text { видів в синтаксоні }\end{array}$ & 8 & 11 & 14 & 17 & 23 & 17 & 23 & 23 & 23 & 22 \\
\hline Кількість описів & 1 & 1 & 32 & 40 & 10 & 28 & 5 & 1 & 1 & 1 \\
\hline Pyrus communis (b) & - & - & II & II & II & I & $\mathrm{I}$ & - & - & + \\
\hline $\begin{array}{l}\text { Crataegus } \\
\text { pseudokyrtostyla (b) }\end{array}$ & - & - & I & I & III & I & III & - & - & - \\
\hline Rosa sp. (b) & - & - & + & + & - & + & IV & - & - & - \\
\hline Poa nemoralis & - & - & $\mathrm{I}$ & + & III & - & III & - & - & - \\
\hline Ulmus laevis (b) & - & - & - & - & - & I & III & - & - & - \\
\hline Acer platanoides (a) & - & - & - & - & - & - & II & - & - & - \\
\hline Dactylis glomerata & - & - & - & + & - & + & III & - & - & - \\
\hline Corydalis solida & - & - & - & - & - & - & III & - & - & - \\
\hline Acer platanoides (b) & - & - & - & - & - & - & III & - & - & - \\
\hline Lamium maculatum & - & - & - & - & - & - & II & - & - & - \\
\hline Stellaria holostea & - & - & - & - & - & - & II & - & - & - \\
\hline Asarum europaeum & - & - & - & - & - & - & II & - & - & - \\
\hline Tilia cordata (a) & - & - & - & - & - & - & II & - & - & - \\
\hline Tilia cordata $(\mathrm{b})$ & - & - & - & - & - & + & I & - & - & - \\
\hline Carpinus betulus (a) & - & - & - & - & - & - & $\mathrm{I}$ & - & - & - \\
\hline Carpinus betulus (b) & - & - & - & - & - & - & II & - & - & - \\
\hline Fraxinus excelsior (a) & - & - & - & - & - & - & I & - & - & - \\
\hline Cerasus avium (b) & - & - & - & - & + & - & $\mathrm{I}+$ & - & - & - \\
\hline Acer campestre (a) & - & - & - & - & - & - & II & - & - & - \\
\hline Adoxa moschatellina & - & - & - & - & - & - & I & - & - & - \\
\hline $\begin{array}{l}\text { Anemone } \\
\text { ranunculoides }\end{array}$ & - & - & - & - & - & - & I & - & - & - \\
\hline Cystopteris fragilis & - & - & - & - & - & - & $\mathrm{I}$ & - & - & - \\
\hline Ficaria verna & - & - & - & - & - & - & I & - & - & - \\
\hline Fragaria vesca & - & - & - & - & - & - & $\mathrm{I}$ & - & - & - \\
\hline Gagea erubescens & - & - & - & - & - & - & $\mathrm{I}$ & - & - & - \\
\hline Gagea minima & - & - & - & - & - & - & I & - & - & - \\
\hline Galeobdolon luteum & - & - & - & - & - & - & I & - & - & - \\
\hline $\begin{array}{l}\text { Chrysosplenium } \\
\text { alternifolium }\end{array}$ & - & - & - & - & - & - & I & - & - & - \\
\hline Epipactis helleborine & - & - & - & - & - & + & - & - & - & - \\
\hline Lapsana communis & - & - & - & - & - & - & $\mathrm{I}$ & - & - & - \\
\hline Carex digitata & - & - & - & - & - & - & $\mathrm{I}$ & - & - & - \\
\hline Ulmus laevis (a) & - & - & - & + & + & - & - & - & - & - \\
\hline Platanthera bifolia & - & - & - & - & - & + & - & - & - & - \\
\hline Lathyrus vernus & - & - & - & - & - & - & I & - & - & - \\
\hline $\begin{array}{l}\text { Polygonatum } \\
\text { multiflorum }\end{array}$ & - & - & - & - & - & + & I & - & - & - \\
\hline Scilla bifolia & - & - & - & - & - & - & $\mathrm{I}$ & - & - & - \\
\hline Viola odorata & - & - & - & - & - & - & II & - & - & - \\
\hline D. sp. cl. Koelerio-Co & yne & hor & tea & & & & & & & \\
\hline Galium verum & - & - & + & IV & II & - & II & - & - & - \\
\hline Festuca beckeri & - & - & + & II & - & - & - & - & - & - \\
\hline Myosotis micrantha & - & - & + & II & - & - & - & - & - & - \\
\hline Artemisia campestris & - & - & + & I & - & + & - & - & - & - \\
\hline Asparagus officinalis & - & - & + & $\mathrm{I}$ & + & + & - & - & - & - \\
\hline Veronica spicata & - & - & - & I & - & - & - & - & - & - \\
\hline Anisantha tectorum & - & - & - & + & - & - & I & - & - & - \\
\hline $\begin{array}{l}\text { Hypericum } \\
\text { perforatum }\end{array}$ & - & - & - & I & - & - & I & - & - & - \\
\hline
\end{tabular}

\begin{tabular}{|c|c|c|c|c|c|c|c|c|c|c|}
\hline Номер синтаксону* & 1 & 2 & 3 & 4 & 5 & 6 & 7 & \multicolumn{3}{|c|}{8} \\
\hline $\begin{array}{l}\text { Середня кількість } \\
\text { видів в синтаксоні }\end{array}$ & 8 & 11 & 14 & 17 & 23 & 17 & 23 & 23 & 23 & 22 \\
\hline Кількість описів & 1 & 1 & 32 & 40 & 10 & 28 & 5 & 1 & 1 & 1 \\
\hline $\begin{array}{l}\text { Phalacroloma } \\
\text { annuum }\end{array}$ & - & - & + & I & - & I & I & - & - & - \\
\hline Genista tinctoria & - & - & + & + & - & - & - & - & - & - \\
\hline Verbascum lychnitis & - & - & + & I & - & - & I & + & - & - \\
\hline Potentilla argentea & - & - & + & $\mathrm{I}$ & - & - & - & - & - & - \\
\hline Sedum sexangulare & - & - & + & $\mathrm{I}$ & - & - & - & - & - & - \\
\hline Sedum telephium & - & - & - & + & - & - & II & - & - & - \\
\hline Asclepias syriaca & - & - & + & $\mathrm{I}$ & - & - & - & - & - & - \\
\hline Crepis tectorum & - & - & - & + & - & - & - & - & - & - \\
\hline Oenothera rubricaulis & - & - & - & $\mathrm{I}$ & $\mathrm{I}$ & $\mathrm{I}$ & - & - & - & - \\
\hline Rumex acetosella & - & - & + & + & - & $\mathrm{I}$ & - & + & + & + \\
\hline Sedum acre & - & - & + & + & - & + & - & - & - & - \\
\hline Poa buldosa & - & - & - & - & - & + & - & - & - & - \\
\hline Polygonum arenarium & - & - & - & + & - & - & - & - & - & - \\
\hline Chondrilla juncea & - & - & - & + & - & - & - & + & - & - \\
\hline Jasione montana & - & - & + & - & - & - & - & + & - & + \\
\hline Silene tatarica & - & - & - & + & - & - & - & - & - & - \\
\hline \multicolumn{11}{|c|}{ D. sp. cl. Molinio-Arrhenatheretea } \\
\hline Poa pratensis & - & - & $\mathrm{I}$ & $\mathrm{I}$ & + & $\mathrm{I}$ & $\mathrm{I}$ & - & - & - \\
\hline Carex hirta & - & - & $\mathrm{I}$ & $\mathrm{I}$ & + & $\mathrm{I}$ & - & - & 1 & + \\
\hline Rumex thyrsiflorus & - & - & $\mathrm{I}$ & $\mathrm{I}$ & - & + & - & - & + & - \\
\hline Galium boreale & - & - & $\mathrm{I}$ & $\mathrm{I}$ & II & $\mathrm{I}$ & - & - & - & - \\
\hline Stelaria graminea & - & - & + & $\mathrm{I}$ & - & - & - & - & - & - \\
\hline $\begin{array}{l}\text { Scutellaria } \\
\text { galericulata }\end{array}$ & - & - & + & I & + & + & - & - & - & - \\
\hline Poa palustris & - & - & $\mathrm{I}$ & + & - & $\mathrm{I}$ & - & - & - & - \\
\hline Equisetum arvense & - & - & + & + & - & $\mathrm{I}$ & - & - & - & - \\
\hline $\begin{array}{l}\text { Achillea } \\
\text { submillefolium }\end{array}$ & - & - & - & I & I & I & II & - & - & - \\
\hline Gratiola officinalis & - & - & - & I & - & + & - & - & - & - \\
\hline Agrostis stolonifera & - & 1 & + & - & - & + & - & - & - & - \\
\hline Mentha arvensis & - & 1 & - & - & - & + & - & - & - & - \\
\hline Thalictrum lucidum & - & - & + & + & - & - & - & - & - & - \\
\hline Ranunculus repens & - & - & + & - & - & $\mathrm{I}$ & - & - & - & - \\
\hline Iris sibirica & - & - & - & + & - & - & - & - & - & - \\
\hline Alopecurus pratensis & - & - & + & + & - & + & - & - & - & - \\
\hline Potentilla reptans & - & - & + & + & - & - & - & - & - & - \\
\hline Theucrium scordium & - & - & + & - & - & + & - & - & - & - \\
\hline Rumex confertus & - & - & + & - & - & - & $\mathrm{I}$ & - & - & - \\
\hline Myosotis palustris & - & - & - & - & - & $\mathrm{I}$ & - & - & - & - \\
\hline Agrostis alba & - & - & - & I & - & - & - & - & - & - \\
\hline Vicia tetrasperma & - & - & - & $\mathrm{I}$ & - & - & - & - & - & - \\
\hline $\begin{array}{l}\text { Ranunculus } \\
\text { polyanthemos }\end{array}$ & - & - & - & I & - & - & - & - & - & - \\
\hline Euphorbia virgata & - & - & + & $\mathrm{I}$ & - & - & - & - & - & - \\
\hline Achillea salicifolia & - & 1 & - & - & - & - & - & - & - & - \\
\hline Allium angulosum & - & - & - & + & - & - & - & - & - & - \\
\hline Althaea officinalis & - & - & - & - & - & + & - & - & - & - \\
\hline Knautia arvensis & - & - & - & - & - & - & $\mathrm{I}$ & - & - & - \\
\hline Caltha palustris & - & - & - & - & - & + & - & - & - & - \\
\hline
\end{tabular}




\begin{tabular}{|c|c|c|c|c|c|c|c|c|c|c|}
\hline Номер синтаксону* & 1 & 2 & 3 & 4 & 5 & 6 & 7 & \multicolumn{3}{|c|}{8} \\
\hline $\begin{array}{l}\text { Середня кількість } \\
\text { видів в синтаксоні }\end{array}$ & 8 & 11 & 14 & 17 & 23 & 17 & 23 & 23 & 23 & 22 \\
\hline Кількість описів & 1 & 1 & 32 & 40 & 10 & 28 & 5 & 1 & 1 & 1 \\
\hline $\begin{array}{l}\text { Ophioglossum } \\
\text { vulgatum }\end{array}$ & - & - & + & - & - & + & - & - & - & - \\
\hline Potentilla anserina & - & - & - & + & - & + & - & - & - & - \\
\hline Trifolium repens & - & - & - & - & - & + & - & - & - & - \\
\hline Trifolium pratense & - & - & - & + & - & + & - & - & - & - \\
\hline Veronica chamaedrys & - & - & - & - & + & - & II & - & - & - \\
\hline Veronica longifolia & - & - & - & + & + & - & - & - & - & - \\
\hline \multicolumn{11}{|c|}{ D. sp. cl. Alnetea glutinosae } \\
\hline Alnus glutinosa (a) & - & - & - & - & - & $\mathrm{I}$ & - & - & - & - \\
\hline Salix cinerea $(\mathrm{b})$ & - & - & + & - & - & + & - & - & - & - \\
\hline $\begin{array}{l}\text { Dryopteris } \\
\text { carthusiana }\end{array}$ & - & - & - & - & - & + & - & - & + & - \\
\hline Solanum dulcamara & - & - & + & - & - & I & - & - & - & - \\
\hline \multicolumn{11}{|c|}{ D. sp. cl. Crataego-Prunetea } \\
\hline $\begin{array}{l}\text { Rhamnus cathartica } \\
\text { (b) }\end{array}$ & - & - & + & + & II & I & - & - & - & - \\
\hline Swida sanguinea (b) & - & - & + & - & IV & + & - & - & - & - \\
\hline Swida sanquinea (c) & - & - & - & - & - & - & III & - & - & - \\
\hline $\begin{array}{l}\text { Crataegus ucrainica } \\
\text { (b) }\end{array}$ & - & - & + & I & - & - & - & - & - & - \\
\hline $\begin{array}{l}\text { Euonymus verrucosa } \\
\text { (b) }\end{array}$ & - & - & - & - & - & - & III & - & - & - \\
\hline Acer tataricum (b) & - & - & + & - & II & + & III & 1 & + & + \\
\hline Malus sylvestris (b) & - & - & - & + & - & + & II & - & - & - \\
\hline Solidago virgaurea & - & - & - & - & - & + & II & + & - & - \\
\hline Armeniaca vulgaris & - & - & - & - & - & + & - & - & - & - \\
\hline Viburnum opulus (b) & - & - & - & - & II & + & - & + & - & - \\
\hline Ligustrum vulgare (b) & - & - & + & - & - & - & - & - & - & - \\
\hline Ligustrum vulgare (c) & - & - & - & - & - & - & $\mathrm{I}$ & - & - & - \\
\hline Lonicera tatarica $(\mathrm{b})$ & - & - & + & - & - & - & - & - & - & - \\
\hline $\begin{array}{l}\text { Chamaecytisus } \\
\text { ruthenicus }\end{array}$ & - & - & - & - & - & - & - & - & - & + \\
\hline Cotinus coggygria (b) & - & - & - & - & III & - & - & - & - & - \\
\hline \multicolumn{11}{|l|}{ D. sp. cl. Artemisietea } \\
\hline $\begin{array}{l}\text { Calamagrostis } \\
\text { epigeios }\end{array}$ & - & - & + & III & - & I & I & 1 & 1 & + \\
\hline Elytrigia repens & - & - & + & III & + & I & - & - & - & - \\
\hline Artemisia vulgaris & - & - & - & + & + & + & I & - & - & - \\
\hline Cichorium intybus & - & - & - & + & - & - & - & - & - & - \\
\hline Artemisia abrotanum & - & - & - & + & - & - & - & - & - & - \\
\hline Arctium lappa & - & - & + & + & - & + & $\mathrm{I}$ & - & - & - \\
\hline $\begin{array}{l}\text { Cynoglossum } \\
\text { officinale }\end{array}$ & - & - & - & I & + & + & - & - & - & - \\
\hline Tanacetum vulgare & - & - & + & $\mathrm{I}$ & - & + & $\mathrm{I}$ & - & - & - \\
\hline \multicolumn{11}{|c|}{ D. sp. cl. Trifolio-Geranietea } \\
\hline Festuca rupicola & - & - & - & - & - & - & II & - & - & - \\
\hline Agrimonia eupatoria & - & - & I & I & - & - & I & - & - & - \\
\hline Allium oleraceum & - & - & - & - & - & - & II & - & - & - \\
\hline $\begin{array}{l}\text { Astragalus } \\
\text { glycyphyllos }\end{array}$ & - & - & - & - & II & - & I & - & - & - \\
\hline $\begin{array}{l}\text { Campanula } \\
\text { bononiensis }\end{array}$ & - & - & - & - & - & - & I & - & - & - \\
\hline
\end{tabular}

\begin{tabular}{|c|c|c|c|c|c|c|c|c|c|c|}
\hline Номер синтаксону* & 1 & 2 & 3 & 4 & 5 & 6 & 7 & \multicolumn{3}{|c|}{8} \\
\hline $\begin{array}{l}\text { Середня кількість } \\
\text { видів в синтаксоні }\end{array}$ & 8 & 11 & 14 & 17 & 23 & 17 & 23 & 23 & 23 & 22 \\
\hline Кількість описів & 1 & 1 & 32 & 40 & 10 & 28 & 5 & 1 & 1 & 1 \\
\hline Origanum vulgare & - & - & - & - & II & - & II & - & - & - \\
\hline Securigera varia & - & - & - & - & - & - & $\mathrm{I}$ & - & - & - \\
\hline \multicolumn{11}{|c|}{ D. sp. cl. Festuco-Brometea } \\
\hline Bromopsis inermis & - & - & + & II & + & + & I & - & - & - \\
\hline Carex praecox & - & - & $\mathrm{I}$ & III & - & $\mathrm{I}$ & - & + & + & + \\
\hline Poa angustifolia & - & - & - & $\mathrm{I}$ & - & - & - & - & - & - \\
\hline Hierochloa odorata & - & - & - & + & - & - & - & - & - & - \\
\hline Ajuga genevensis & - & - & + & + & - & - & I & - & - & - \\
\hline Ranunculus illyricus & - & - & - & - & - & - & $\mathrm{I}$ & - & - & - \\
\hline Viola hirta & - & - & - & - & - & - & $\mathrm{I}$ & - & - & - \\
\hline Viscaria vulgaris & - & - & - & - & - & - & $\mathrm{I}$ & - & - & - \\
\hline Pimpinella saxifraga & - & - & - & - & - & - & $\mathrm{I}$ & - & - & - \\
\hline \multicolumn{11}{|l|}{ Інші види } \\
\hline Plantago major & - & 1 & - & $\mathrm{I}$ & - & I & - & - & - & - \\
\hline Poa апnиа & - & - & - & + & - & - & $\mathrm{I}$ & - & - & - \\
\hline Polygonum aviculare & - & - & - & + & - & - & - & - & - & - \\
\hline Lactuca tatarica & - & - & + & - & - & + & - & - & - & - \\
\hline Cirsium arvense & - & - & + & + & - & + & - & - & - & - \\
\hline Myosoton aquaticum & - & - & - & - & - & + & - & - & - & - \\
\hline Morus nigra $(\mathrm{a})$ & - & - & + & + & - & + & - & - & - & - \\
\hline Morus nigra $(\mathrm{c})$ & - & - & - & - & - & + & - & - & - & - \\
\hline Pinus austriaca (a) & - & - & - & - & - & - & II & - & - & - \\
\hline $\begin{array}{l}\text { Fraxinus } \\
\text { pennsylvanica (b) }\end{array}$ & - & - & + & - & - & + & - & - & - & - \\
\hline Padus serotina $(\mathrm{b})$ & - & - & - & - & - & - & - & + & - & - \\
\hline $\begin{array}{l}\text { Elaeagnus } \\
\text { angustifolia }\end{array}$ & - & - & + & - & - & - & - & - & - & - \\
\hline $\begin{array}{l}\text { Hieracium } \\
\text { umbellatum }\end{array}$ & - & - & - & + & - & - & - & + & - & - \\
\hline $\begin{array}{l}\text { Chamaenerion } \\
\text { angustifolium }\end{array}$ & - & - & - & - & - & - & - & 1 & - & - \\
\hline Carex ericetorum & - & - & - & - & - & - & - & + & - & - \\
\hline Echinocystis lobata & - & - & - & - & - & + & - & - & - & - \\
\hline Galeopsis bifida & - & - & - & + & - & - & - & - & - & - \\
\hline Medicago lupulina & - & - & - & - & - & + & - & - & - & - \\
\hline Inula britannica & - & - & - & + & - & - & - & - & - & - \\
\hline Linaria vulgaris & - & - & + & - & - & - & - & - & - & - \\
\hline
\end{tabular}

*Позначено асоціації: 1 - Acoretum calami; 2 - Caricetum acutiformis; 3 - Euphorbio virgultosae-Amorphaetum fruticosae; 4 - Artemisio dniproicae-Salicetum acutifoliae; 5 - SaliciPopuletum; 6 - Salicetum albae; 7 - Chelidonio-Robinietum; 8 - com. Amorpha fruticosa + Rubus.

Літерами після назви виду позначені яруси: деревний (a), чагарниковий (b), трав’яний (c)

Layers are indicated by the letters after species names: tree (a), shrub (b), grass (c) 
Robinietum, що формуються у штучних мішаних насадженнях із Robinia pseudoacacia, P. sylvestris, Q. robur. Загалом тут популяції $A$. fruticosa мають штучне походження, рослини перебувають здебільшого у пригніченому стані, вид відіграє роль асектатора в чагарниковому ярусі. Під час маршрутних обстежень нами відмічались окремі випадки ценопопуляцій 3 подібними характеристиками життєвості й для союзу Carpinion Issler 1931. У штучних посадках $P$. sylvestris, на боровій терасі, де $A$. fruticosa висівався як фітомеліоративна порода, його ценопопуляції спроможні до тривалого існування лише на більш освітлених ділянках узлісь та рідколісь. Описані нами випадки таких угруповань, синтаксономічний статус яких до рівня асоціації важко встановити через недостатню кількість описів, слід відносити до союзу Dicrano-Pinion. Високе покриття в цих фітоценозах має виявлений нами на лівобережжі представник роду Rubus L. (секція Glandulosi P.-J. Mull. підроду Eubatus Focke), видова приналежність якого наразі нами не з'ясована. За цих умов A. fruticosa також формує лише розріджений ярус (5-10\% проективного покриття) і не спроможний проявляти широку експансію.

\section{Висновки}

Фітоценози Середнього Придніпров'я, в яких зростає A. fruticosa належать до 4 класів, 5 порядків, 7 союзів, 7 асоціацій, в складі союзу Dicrano-Pinion до одного специфічного угруповання, що не ідентифіковане до рівня асоціації. Центральною ланкою рослинності регіону, в якій ценопопуляції виду мають стабільні характеристики проективного покриття, є заплавний гігромезофільний демутаційно-сукцесійний ряд, представлений угрупованнями синтаксонів: Phragmition communis + Magnocaricion elatae + Molinietalia - Rubo caesiAmorphion fruticosae - Salicion albae. Крайовою зоною фітоценотичного діапазону в умовах заплави для A. fruticosa є ксеромезофільний демутаційносукцесійний ряд представлений угрупованнями синтаксонів: Galietalia veri - Artemisio dniproicaeSalicion acutifoliae - Dicrano-Pinion. Випадки зростання аморфи в угрупованнях класів Robinietea, Carpino-Fagetea найчастіше є залишковим ефектом від застосування цього виду в лісовому господарстві як фітомеліоративно-грунтопокращуючої породи.

\section{СПИСОК ПОСИЛАНЬ}

Blagojević M., Konstantinović B., Kurjakov A., Samardźić N. 2014. Seed bank of Amorpha fruticosa L. on some ruderal sites in Serbia. In: Neobiota 2014. 8-th International conference on biological invasions from understanding to action. Antalya, Turkey, p. 74.

Chauge N., Fried G. 2011. Community-level impacts of three invasive alien plants in Mediterranean coastal habitats In: $3^{\text {th }}$ International symposium enviromental weeds and invasive plants. Monteverite, p. 17.

Csiszer A., Korda M., Schmidt D., Sporčić D., Teleki B., Tiborcz V., Zagyvai G., Bartha D. 2013. Allelopathic potential of some invasive woody plant species occurring in Hungary. Allelopathy Journal, 31(2): 309-318.

De Haan L.J., Ehlke N.J., Sheaffer C.C., Wyse D.L., De Haan R.L. 2006. Evaluation of diversity among North American accession of False Indigo (Amorpha frutico$s a$ L.) for forage and biomass. Genetic Resources and Crop Evolution, (53)7: 1463-1476.

Egoshyn A.V. 2014. Izvestia Saratovskogo universiteta. Series chimia, biologia, ekologia, 14(4): 36-62. [Егошин А.В. 2014. Чужеродные виды юга Российского Причерноморья, их биоклиматические и эколого-географические требования. Известия Саратовского университета. Серия химия, биология. экология, 14(4): 36-62].

Evtushenko T.M., Ivan'ko I.A. 2009. In: Bioriznomanittya ta rol tvaryn $v$ ekosystemakh: Materialy $V$ Mizhnarodnoi naukovoi konferentsii. Dnipropetrovsk, pp. 10-11. [Евтушенко T.M., Іванько I.A. 2009. Особливості деревних культуро-фітоценозів парку імені Воронцова м. Дніпропетровськ. У зб.: Біорізноманіття та роль тварин в екосистемах: Матеріали $V$ Міжнародної наукової конференції. (Дніпропетровськ, 12-16 жсовня 2009 р.). Дніпропетровськ, с.10-11].

Karmyzova L. 2014. Ecological study of invasive Amorpha fruticosa at research biological stations within steppe zone, Ukraine. Kharkiv National University Journal. Series Biology, (22)11: 300-304.

Kelbel P. 2012. Comparison of invasive woody plant species presense in the Botanical garden of P.J. Šafarik University in Košice from the viewpoint of time and management of sanitation measures. Thaiszia - Journal of Botany, (22)2: 163-180.

Kosman E.G., Sirenko I.P., Solomakha V.A., Sheliag-Sosonko J.R. 1991. Ukrainian Botanical Journal, 48(2): 98104. [Косман С.Г., Сіренко І.П., Соломаха В.А., Шеляг-Сосонко Ю.Р. 1991. Новий комп'ютерний метод обробки описів рослинних угруповань. Український ботанічний журнал, 48(2): 98-104.]

Kuzemko A.A., Chorna G.A. 2002. Ukrainian Phytosociological Collection. Series A, 1(18): 15-31. [Куземко Ф.Ф., Чорна Г.Ф. 2002. Лісова рослинність долини р. Рось. II. Заплавні ліси (Класи Alnetea glutinosae, Salicetea purpureae). Український фітоценотичний збірник, Серія А, 1(18): 15-31].

Lyubchenko V.M. 1987. Bulleten Glavnogo Botanicheskogo Sada, 46: 48-50. [Любченко В.М. 1987. Распространение аморфы кустарниковой в фитоценозах Канев- 
ского заповедника. Бюллетень главного ботанического сада, 46: 49-50].

Lyubchenko V.M., Bortnyak M.M. 1986. Ukrainian Botanical Journal, 43(5): 16-20. [Любченко В.М., Бортняк М.М. 1986. Рослинність Канівського державного заповідника (за даними великомасштабного геоботанічного картування). Український ботанічний журнал, 43(5): 16-20].

Manuilova G.M. 2005. Fitomelioration of virgin landscapes in the conditions of Lviv Region Cand. Sci. Diss. Abstract. Lviv, Ivan Franko National University of Lviv, 19 pp. [Мануїлова Г.М. 2005. Фітомеліорація девастованих ландшафтів в умовах Львівщини: автореф. дис. канд. біол. наук: спец. 03.00.05 "Ботаніка". Львів, Університет імені I. Франка, 19 с.].

Matuszkiewicz Wł. 2001. Przewodnik do oznaczania zborowisk roślinnych Polski. Warszawa: Wyd-wo Naukove PWN, 540 pp.

Mirkin B.M., Naumova L.G. 1998. Prodromus $i$ diagnosticheskie vidy vysshych edinic rastitelnosti territorii byvshego SSSR. Ufa: Gilem, 335-412 рр. [Миркин Б.М., Наумова Л.Г. 1998. Продромус и диагностические виды высших единии, растительности территории бывшего СССР. Уфа: Гилем, 335-412 с.].

Moravec J. Rostlinná společenstva České republiky a jejich ohrožení. 2 vyd. Litoměřice: Severočeská pobočka České botanické společnosti, $206 \mathrm{~s}$.

Mosyakin S.L., Fedoronchuk M.M. 1999. Vascular plants of Ukraine. A nomenclatural checklist. Kyiv, xxii + 345 pp.

Mucina L., Bültmann H., Dierßen K., Theurillat J.P., Raus T., Čarni A., Sumberová K., Willner W., Dengler J., García R.G., Chytrý M., Hájek M., Di Pietro R., Iakushenko D., Pallas J., Daniëls F.J.A., Bergmeier E., Guerra A.S., Ermakov N., Valachovič M., Schaminée J.H.J., Lysenko T., Didukh Ya.P., Pignatti S., Rodwell J.S., Capelo J., Weber H.E., Solomeshch A., Dimopoulos P., Aguiar C., Hennekens S.M., Tichý L. 2016. Vegetation of Europe: hierarchical floristic classification system of vascular plant, bryophyte, lichen, and algal communities. Applied Vegetation Science, 19(Suppl. 1): 3-264.

Ruzhilenko N.S. 2002. Visnyk Luhanskoho derzhavnoho pedahohichnoho instytutu, 45(1): 125-135. [Ружіленко Н.С. 2002. Видовий склад і динаміка населення землерийок (Soicidae) заплавних островів Канівського заповідника Вісник Луганського державного педагогічного інституту, 4(1): 125-135].

Seibold S., Fischer A. 2008. Suppression of alien invasive species by traditional land use forms: Amorpha frutico$s a$ L. in the Croatian nature park Lonsjko Polje. Sauteria, 20: $265-276$
Sărățeanu V., Horablaga M.N., Stroia M.S., Butnarin M., Bostan C. 2008. Approach on the shrub invasive species impact on western Romanian grasslands. Lucrări Ştiinţifice Facultatea de Agricultură. Timişoara, 40(1): 315-318.

Senchilo O.O., Vorobyov Ye.O., Shevchyk V.L., Solomakha I.V. 1999. Ukrainian Phytosociological Collection. Series A. Phytosociology, 3(14): 58-67. [Сенчило О.О., Воробйов Є.О., Шевчик В.Л., Соломаха І.В. 1999. Деревно-чагарникова рослинність острова Просеред. Український фітоценотичний збірник. Серія А. Фітоценологія, 3(14): 58-67].

Shevchyk V.L., Borysenko M.M., Shevchyk T.V. 2015. Naukovi osnovy zberezhennia biotychnoji riznomanitnosti, 13(5): 195-202. [Шевчик В.Л., Борисенко М.М., Шевчик Т.В. 2015. Amorpha fruticosa L. (Fabaceae) на заплаві Канівського природного заповідника та можливості корекції фітоценозів з ііі участю. Наукові основи збереження біотичної різноманітності, 13(5): 195-202].

Shevchyk V.L, Shevchyk T.V., Tsynda R.V. 2013. In: Naukovi zapysky pryrodnogo zapovidnyka "Mys Martian", vyp.4: Materialy mizhnar. nauk. konf. Yalta, pp. 106-107. [Шевчик В.Л., Шевчик Т.В., Цинда Р.В. Червонокнижні види Придніпровського лісостепу. Стан популяцій та перспективи їх активної охорони. В зб.: Наукові записки природного заповідника "Мис Мартян", вип. 4: Матеріали міжнар. наук конф. (Ялта, 14-17травня 2013 р.). Ялта, 2013, с. 106-107].

Shevchyk V.L., Solomakha V.A. 1996. Ukranian Phytosociological Collection. Series A. Phytosociology, 1: 12-27. [Шевчик В.Л., Соломаха В.А. 1996. Синтаксономія рослинності островів Круглик та Шелестів Канівського природного заповідника. Український фітоценологічний збірник. Серія А. Фітоценологія, 1: 12-27].

Sirenko I.P. 1996. Ukrainian Phytosociological Collection. Series A. Phytosociology, 1: 9-11. [Сіренко I.П. 1999. Створення баз даних для фітоценологічного і флористичного аналізу Український фітоценологічний збірник. Серія А. Фітоценологія, 1: 9-11].

Solomakha V.A. 2008. Syntaksonomiya roslynnosti Ukrainy. Tretye nablyzhennya. Kyiv: Fitosotsiotsentr, 296 pp. [Coломаха В.А. 2008. Синтаксономія рослинності України. Третє наближення. Київ: Фітосоціоцентр, 296 с.].

Weber H., Moravec J., Theurillat J. 2000. International Code of Phytosociological Nomenclature. $3^{\text {rd }}$ edition. Journal of Vegetation Science, 11: 739-768.

Рекомендує до друку

Надійшла 23.04.2018 


\title{
Schoenoplectiella mucronata (Cyperaceae) у флорі України
}

\author{
Іван І. МОЙСІЕНКО ${ }^{1}$, Іван М. ДАНИЛИК ${ }^{2}$, Руслана П. МЕЛЬНИК ${ }^{1}$, Олена Ф. САДОВА \\ Марина Я. ЗАХАРОВА ${ }^{1}$ \\ ${ }^{1}$ Херсонський державний університет \\ вул. Університетська 27, Херсон 73000, Україна \\ ivan.moysiyenko@gmail.com \\ ${ }^{2}$ Інститут екології Карпат НАН України \\ вул. Козельницька 4, Львів 70026, Україна \\ idanylyk@ukr.net \\ ${ }^{3}$ Національний природний Парк "Олешківські піски" \\ провул. Ракитний 16, Олешки 75100, Херсонська обл., Україна \\ sadova.npp@gmail.com
}

Moysiyenko I.I. ${ }^{1}$, Danylyk I.M. ${ }^{2}$, Melnyk R.P. ${ }^{1}$, Sadova O.F. ${ }^{3}$, Zakharova M.Ya. ${ }^{1}$ 2019. Schoenoplectiella mucronata (Cyperaceae) in the flora of Ukraine. Ukrainian Botanical Journal, 76(1): 52-59.

${ }^{1}$ Kherson State University

27 University Str., Kherson 73000, Ukraine

${ }^{2}$ Institute of Ecology of the Carpathians, National Academy of Sciences of Ukraine

4 Kozelnytska Str., Lviv 79026, Ukraine

${ }^{3}$ Oleshkivski PiskyNational Nature Park

16 Rakytnyi Lane, Oleshky 75100, Kherson Region, Ukraine

Abstract. The article presents results of a comprehensive study of the rare species Schoenoplectiella mucronata (Cyperaceae) included in the $3^{\text {rd }}$ edition of the Red Data Book of Ukraine (2009). The nomenclatural references and most commonly used synonyms are given, taking into account new generalized data on the genus Schoenoplectiella from morphological and molecular phylogenetic studies. An analysis of distribution patterns of $S$. mucronata in Ukraine has also been carried out in this study. Four localities were recorded - two localities based on herbarium data and two localities from scientific literature. One of these localities is in Odessa Region and another in Kherson Region. Of these four sites, one was investigated in situ, where an analysis of the phytocenological and populational characteristics has been carried out. It has been established that $S$. mucronata is confined to the plant communities of the classes Phragmito-Magnocaricetea and Oryzetea sativae and forms populations of the normal type with a right-side age spectrum. Because of its synanthropic character and significant segetal activity, its conservation status remains unclear.

Keywords: Cyperaceae, distribution, Scirpus, Schoenoplectus, Schoenoplectiella, nomenclature, phytocoenotic and population peculiarities, rare species, Ukraine

Мойсієнко I.І., Данилик І.М., Мельник Р.П., Садова О.Ф., Захарова М.Я. 2019. Schoenoplectiella mucronata (Cyperaceae) у флорі України. Український ботанічний журнал, 76(1): 52-59.

Резюме. Наведено результати комплексних досліджень рідкісного у флорі України виду Schoenoplectiella mucronata (Cуреraceae), який включений до третього видання "Червоної книги України" (2009). Подано номенклатурну цитацію та найуживаніші синоніми з урахуванням нових узагальнених даних морфологічних і молекулярно-філогенетичних досліджень роду Schoenoplectiella. Здійснено аналіз території поширення S. mисronata в Україні. На сьогодні відомо чотири місцезнаходження, по два за гербарними та літературними даними, одне з території Одеської та три Херсонської обл. У виявлених нами локалітетах проведені аналізи його фітоценотичних і популяційних особливостей. Встановлено, що S. mucronata приурочений до угруповань рослинності класів Phragmito-Magnocaricetea й Oryzetea sativae та формує популяції нормального типу з правостороннім віковим спектром. Нез'ясованим залишається статус цього виду, адже встановлено його синантропний характер зі значною сегетальною активністю.

Ключові слова: номенклатура, поширення, рідкісний вид, фітоценотичні та популяційні особливості, Україна, Cyperaceae, Schoenoplectus, Schoenoplectiella, Scirpus

(c) I.І. МОЙСІЕНКО, І.М. ДАНИЛИК, Р.П. МЕЛЬНИК, О.Ф. САДОВА, М.Я. ЗАХАРОВА, 2019 
У флорі України родина Cуреraceae Juss. відзначається не тільки значною таксономічною різноманітністю (Danylyk, 2012), але й наявністю в іiі складі збірних родів, які в рамках філогенетичної систематики були розділені на окремі (самостійні) роди. До таких таксонів, зокрема, належить рід Scirpus L. s. 1., який на підставі результатів молекулярного аналізу розподілений на багато сегрегатних родів, у т. ч. й рід Schoenoplectiella Lye (Lye, 2003), до якого тепер зараховують близько 50-60 видів (Jung, Choi, 2010; Hayasaka, 2012; Shiels et al., 2014; Govaerts et al., 2018; Roskov et al., 2018).

Оскільки рід Schoenoplectiella описаний відносно нещодавно, у формі дихотомічного ключа наводимо його відміни від роду Schoenoplectus (Rchb.) Palla s. str. (враховані види флори України):

1. Рослини багаторічні; кореневища видовжені або повзучі; горішки гладкі ....Schoenoplectus s. str. - Рослини однорічні або багаторічні; кореневища дуже короткі та приховані серед нижніх листкових лусок; горішки поперечно-зморшкуваті Schoenoplectiella

В Україні рід Schoenoplectiella представлений трьома видами (Schoenoplectiella mucronata (L.) J. Jung \& H.K.Choi, S. supina (L.) Lye та S. melanosperma (C.A.Meyer) Danylyk, Olshanskyi \& Zhygalova) (Danylyk et al., 2017). Усі вони традиційно розглядалися в роді Scirpus (Krechetovich, 1940; Egorova, 1976) або в Schoenoplectus (Popov, 1950; Барбарич, 1965, 1987; Egorova, 2005; Danylyk, 2012).

Серед видів роду Schoenoplectiella високим созологічним статусом відзначається $S$. mucronata, який є дуже рідкісним видом флори України та включений (як Schoenoplectus mucronatus (L.) Palla) до третього видання Червоної книги України (Danylyk, 2009). У сусідніх з Україною державах цей вид з високим созологічним статусом (категорія ЕN) охороняється в Польщі (Banaś, Kruk, 2014; Rybak et al., 2016), в Словаччині вважається зниклим видом (категорія EX), (Marhold, Hindak, 1998). Schoenoplectiella mucronata прореферований у міжнародних природоохоронних списках: Європейському Червоному списку судинних рослин i Червоному списку IUCN, однак отримав в обох списках низький созологічний статус (категорія LC) (Bilz et al., 2011; Lansdown, 2013). У всіх цих природоохоронних зведеннях використовувалася родова назва Schoenoplectus. Тому, зважаючи на необхідність сучасного трак- тування назви, наводимо номенклатурну цитату цього виду.

Schoenoplectiella mucronata (L.) J.Jung \& H.K.Choi, 2010, J. Pl. Biol. 53(3): 230. - Scirpus mucronatus L. 1753, Sp. Pl.: 50; Егорова, 1976, Фл. европ. части СССР, 2: 92. - Schoenoplectus mucronatus (L.) Palla, 1888, Bot. Jahrb. Syst. 10: 299; Попов, 1950, Визн. росл. УРСР: 804; Барбарич, 1965, Визн. росл. Укр.: 117; Барбарич, 1987, Опред. высш. раст. Укр.: 419. - Кугайник гострокінцевий.

Ареал цього виду охоплює значну територію: середню та південну частини Евразії, північ Африки, північний захід Австралії; як інтродуцент вид поширений у західній частині Північної Америки (Casper, Krausch, 1980; Smith, 2002; Pignotti, 2003; Egorova, 2005; DeBerry et al., 2010; Govaerts et al., 2018; Roskov et al., 2018). У флорі України $S$. mucronata донедавна був відомий лише з одного місцезнаходження - на Козачелагерській арені Нижньодніпровських пісків, де був зібраний лише одного разу понад 80 років тому. На жаль, місцезнаходження єдиного гербарного зразка, що зберігався в Гербарії Інституту ботаніки ім. М.Г. Холодного (KW) не відомо з 2009 року. Однак попередньо він був критично опрацьований одним із авторів даної статті (I.М. Даниликом). На етикетці цього зразка зазначено: "Козаче-Лагерська піскова арена, 04.09.1932 p. Leg. М. Косець Det. М. Попов". 3 невідомих причин S. mucronata не був включений у фундаментальне зведення "Флора УРСР" (Krechetovich, 1940). Під час підготовки першого українського видання "Визначника..." ця помилка була виправлена i, таким чином, цей вид під назвою Schoenoplectus mucronatus уперше наводиться для території України з нотаткою: "На солонцюватих заболочених місцях. Степ (зрідка в пониззі Дніпра)" (Рopov, 1950, p. 804). Незважаючи на те, шо вказівка на конкретне місцезнаходження не зазначена, 3 великою ймовірністю можна стверджувати, що М.Г. Попов спирався на гербарний зразок, зібраний саме М.I. Косцем. У подальші роки 20-го століття зібрати цей вид більше нікому не вдалося, а всі наступні цитування (Барбарич, 1965, 1987; Egorova, 2005; Danylyk, 2009) наводилися за вказаним вище гербарним зразком. Тому важливу наукову цінність матиме будьяка достовірна інформація про цей вид, зокрема підтвердження та нові його знахідки, здійснені на початку 21-го століття. 
A
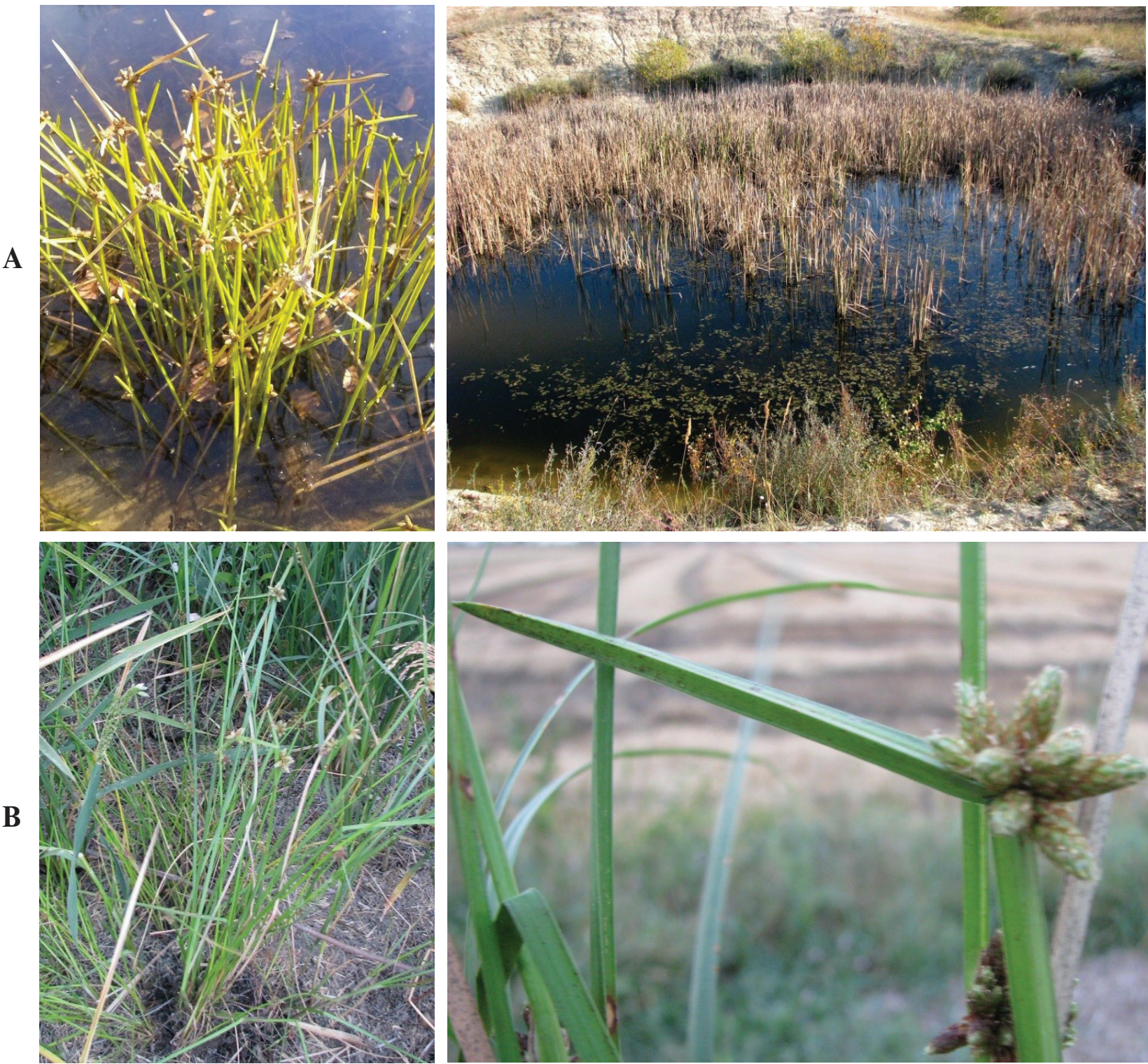

Рис. 1. Schoenoplectiella mucronata з різних місцезнаходжень в Херсонській області (Україна). А: місцезнаходження 1 (Національний природний парк "Олешківські піски"); В: місцезнаходження 2 (рисове поле в околицях с. Гаврилівка Друга)

Fig. 1. Schoenoplectiella mucronata from different localities in Kherson Region (Ukraine). A: locality 1 (Oleshkivski Pisky National Nature Park); B: locality 2 (rice field in the vicinity of Gavrylivka Druga village)

У літературних джерелах сільськогосподарського призначення $є$ інформація про значне поширення S. mucronata (як сегетального виду) в посівах рису на півдні України: Одеська обл., Кілійський р-н, м. Кілія (Babayanc, Nepliy, 2014) і Херсонська обл., Скадовський р-н, с. Антонівка (Dudchenko, Dudchenko, 2011) (рис. 2). На рисових полях $S$. mucronata проявляє себе як бур'ян та "засмічує" монокультурні посіви рису й місця, де постійно стоїть вода. Рослини дуже чутливідо посух, але витримують глибоке та тривале затоплення. Ріст вегетативних органів навесні відбувається за температури $10-11{ }^{\circ} \mathrm{C}$, тобто до появи проростків pису (Fischer et al., 2010; Dudchenko, Dudchenko, 2011; Babayanc, Nepliy, 2014). Ці відомості досить цікаві, але потребують перевірки, оскільки гербарних зразків ми не бачили.

В останні роки $S$. mucronata був виявлений нами у двох локалітетах на території Херсонської обл.: 1) природному (рис. 1, А) - повторна знахідка 


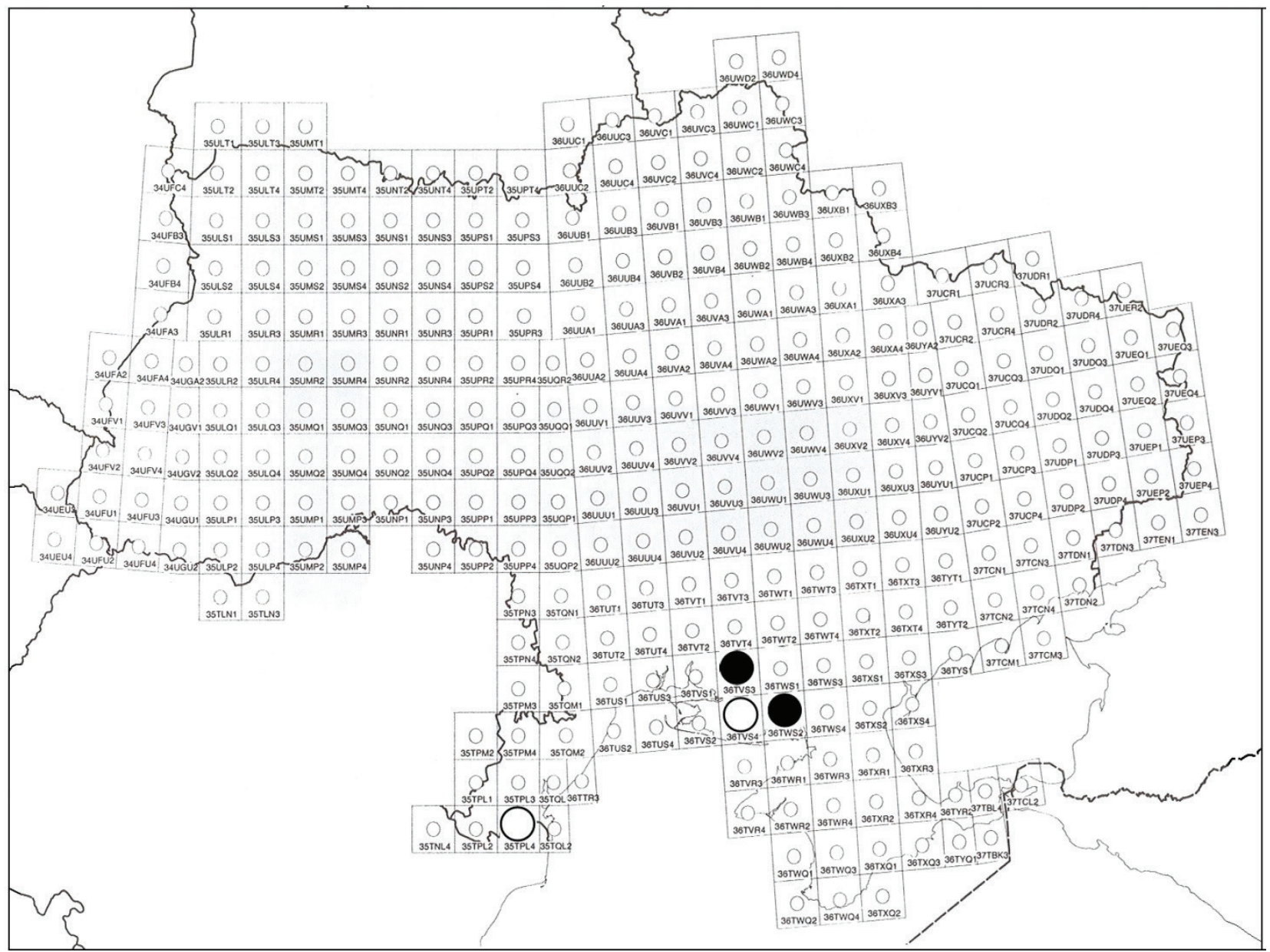

Рис. 2. Поширення Schoenoplectiella mucronata в Україні: за гербарними (О) та літературними (О) даними

Fig. 2. Distribution of Schoenoplectiella mucronata in Ukraine: herbarium (O) and literature (O) data

на Козачелагерській арені Нижньодніпровських пісків (Національний природний парк "Олешківські піски") - місцезнаходження 1; 2) антропогенному (рис. 1, В) - нова знахідка в околицях с. Гаврилівка Друга на рисових полях місцезнаходження 1. Останнє віддалене від першого на південний-схід на понад 50 км (рис. 2). Наводимо детальну характеристику природного місцезнаходження цього виду, включаючи фітоценотичні та популяційні його особливості.

Місцезнаходження 1. Херсонська обл., Олешківський (нещодавно Цюрупинський) р-н, Нижньодніпровські піски, Козачелагерська арена, Національний природний парк (НПП) "Олешківські піски", кв. 107, прибережно-водні зарості та заболочені місця, 03.10.2016. Leg. Мойсієнко I.I., Садова О.Ф., Захарова М.Я. Det. Мойсієнко I.I.
(KHER); там само, 26.07.2018 Leg. \& Det. Мойсієнко I.I., Данилик I.M., Захарова М.Я., Мельник Р.П. (KHER).

На території Козачелагерської арени S. mucronata трапляється в центральній іiі частині, що раніше належала до військового полігону "Херсон", а нині входить до складу Раденського природоохоронного науково-дослідного відділення НПП "Олешківські піски" (рис. 3). У цьому місцезнаходженні нами було виявлено три популяційні локуси в 2016 р. і два - в 2018 р., які досить віддалені один від одного й ценотично та популяційно дешо відмінні.

Локус № 1 (N 46.593983, E 33.051967º, 03.10.2016. Розташований на узліссі березового гайка (колки), біля та в невеличкому озерці правильної форми, що утворилося на дні вирви (діаметр 8,5 м, схили крутизною 20-35). На 

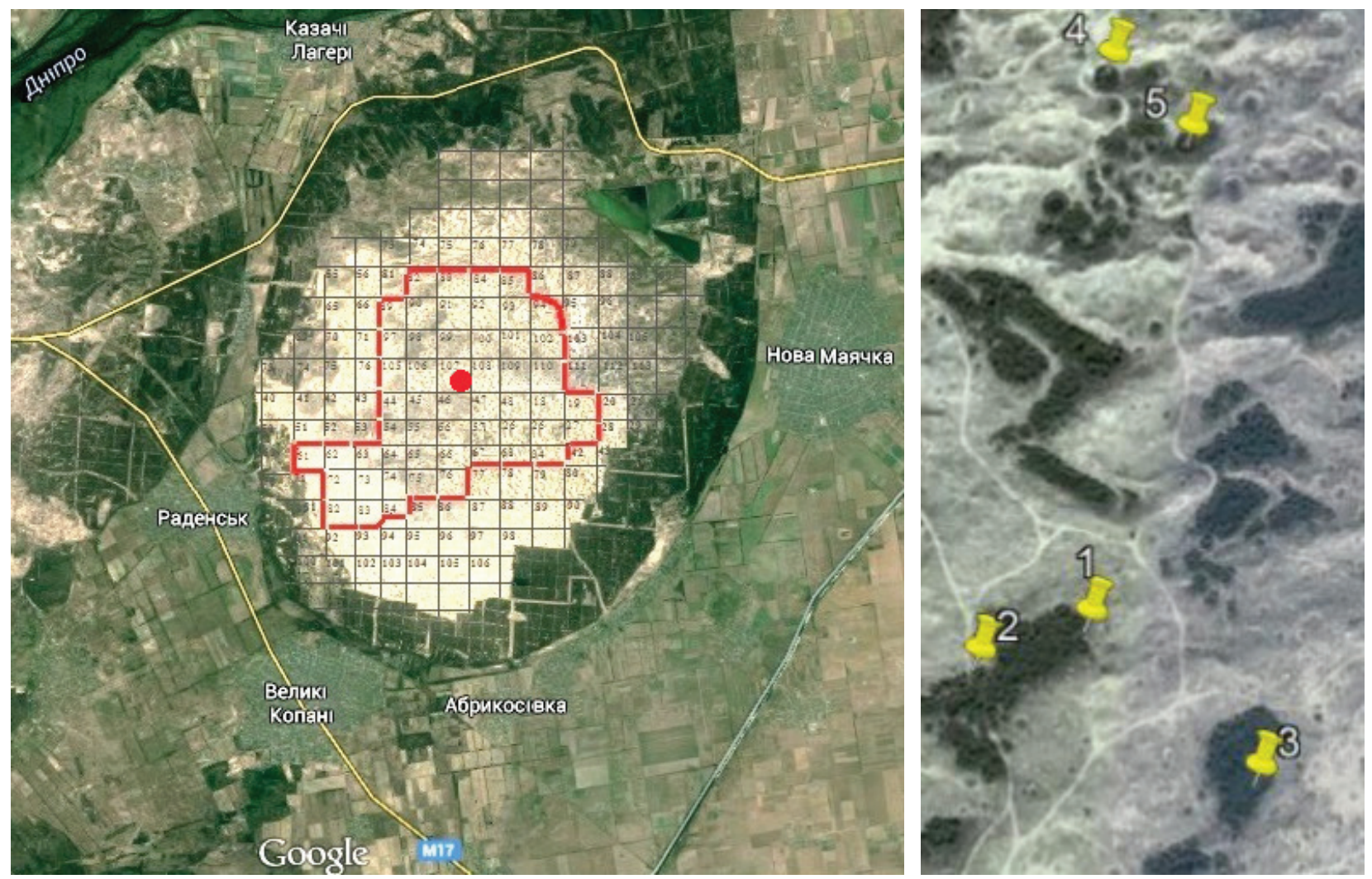

Рис. 3. Картосхема (Google) території природоохоронного науково-дослідного відділення "Раденське" національного природного парку "Олешківські піски" 3 лісо-таксаційною квартальною сіткою. Умовні позначення: - межа природоохоронного науково-дослідного відділення "Раденське"; - місцезнаходження Schoenoplectiella mucronata ( - локуси 1-5)

Fig. 3. A Google map of Oleshkivski Pisky National Nature Park, Radensky Conservational Research Department with forest taxation units. Symbols: - boundary of the Radensky Conservational Research Department; - locality of Schoenoplectiella mucronata ( - locus $1-5)$

момент дослідження його площа становила 4 м², глибина - 0,3 м. Schoenoplectiella mucronata росте по берегу та безпосередньо у воді смугою до 0,5 м завширшки. На час дослідження (осінь) рівень води в озері був надзвичайно низьким (весною на 0,4 м вищий, і тоді всі особини перебували у складі прибережно-водних заростей). Оселище має різкозмінний режим зволоження, шо призводить до характерного фітоценотичного складу угруповання: S. mucronata - 40\%, Betula borysthenica Klokov (juv.) - 5\%, Salix alba L. (juv.) - 5\%, Salix rosmarinifolia L. $-10 \%$, Lythrum salicaria L. $-10 \%$, Typha angustifolia L. - 5\%, Juncus articulatus L. $2 \%$, Calamagrostis epigeos (L.) Roth - 2\%, Gratiola officinalis L. - +, Jacobaea borysthenica (DC.) B.Nord. \& Greuter -+ , Lotus angustissimus L. - + Загалом було виявлено 71 особину S. mucronata (з них: 13 - вегетативних і 58 - генеративних).
Висота ювенільних рослин становила 5-13 см, генеративних - до 73 см, відстань між особинами в середньому $-37 \mathrm{~cm}$.

Локус № 2 (N 46.592483, E $33.050850^{\circ}$ ), 03.10.2016. Той же гайок, західна його межа. Рослини виду виявлені на грунтовій дорозі в пониженні біля невеликого, суцільно зарослого озерця. Це угруповання характеризується таким видовим складом: S. mucronata - +, Phragmites australis (Cav.) Trin \& Steud - 30\%, Alisma plantagoaquatica L. - 7\%, Lythrum salicaria - 3\%, Agrostis gigantea Roth $-1 \%$, Pycreus flavescens (L.) Rchb. $5 \%$, Juncus articulatus - +, J. conglomeratus L. - +, Calamagrostis epigeos -+ , Lotus anguistissimus -+ , Cyperus michelianus (L.) Delile - r. Загалом було виявлено 7 генеративних особин $S$. mucronata, 3 яких 6 - сухі цьогорічні, висотою, що не перевищує 55 см. Загибель особин могла бути зумовлена як 
зневодненням екотопу під час літньої спеки, так і антропогенним впливом у ході використання дороги.

Локус №3 (N 46.593017 , E 33.054117º), 26.07.2016. Осокове болото посеред березового гайка. Рослини Schoenoplectiella mucronata розташовані невеликими групами (проективне покриття 5\%), у місцях 3 розрідженим трав'яним покривом. Деревний ярус утворює Betula borysthenica (частина особин сухі, ймовірно, внаслідок вимокання), чагарниковий Salix cinerea L.). У трав'яному ярусі виразно домінує Carex acutiformis Ehrh. - 55\%. Також відмічені: Juncus effusus L. - 5\%, Lythrum virgatum L. - 5\%, Calamagrostis canescens (Weber) Roth - 5\%, Phragmites australis $-3 \%$, Potamogeton natans L. - 3\%, Juncus articulatus - 1\%. У цьому локусі виявлено 36 особин (2 вегетативних і 34 генеративних), їхня висота не перевищує $56 \mathrm{~cm}$.

Локус № 4(N 46.598358 , E 33.051183 ), 26.07.2018. Озеро у вирві від авіаційної бомби площею близько $50 \mathrm{M}^{2}$. Берег досить крутий (до $35^{\circ}$ ), вкритий негустим рослинним покривом (Salix cinerea -+ , Lythrum salicaria $-1 \%, S$. rosmarinifolia -+ тощо). Shoenoplectiella mucronata зростає на глибині до 30 см у розріджених прибережно-водних заростях (Typha angustifolia - 5\%, S. mucronata - 5\%, Juncus articulatus $-\mathrm{r}$ та Lythrum salicaria -+ ). Також тут відмічені Potamogeton natans L. $-1 \%$ та Utricularia vulgaris L. - + З Загалом в озері виявлено 51 особину S. mucronata (42 вегетативних і 9 генеративних). Висота ювенільних рослин становить 5-13 см, генеративних - до 73 см, середня відстань між особинами - $37 \mathrm{~cm}$.

Локус № 5 (N 46.597865 , E 33.052256 ), 26.07.2018. Розташоване неподалік локусу № 4 таке саме озерце у вирві з подібним рослинним покривом. В озері нами відмічено 15 особин S. mucronata, більшість 3 яких генеративні.

Не виникає сумніву, що нами виявлено саме те місцезнаходження, де $S$. mucronata був уперше знайдений в Україні М.I. Косцем майже 90 років тому. На досліджуваній території вид приурочений до прибережно-водних і болотних угруповань, що формуються в комплексі з березовими гайками в котловинах видування серед пісків. Переважно в розріджених ценозах на вологих піщаних грунтах у складі угруповань класу Phragmito-Magnocaricetea Klika in Klika \& Novák 1941.

Загальна площа виявленої популяції, яка розділена на п'ять ізольованих унаслідок мозаїчності ландшафту та більш-менш віддалених локусів (відстань між крайніми 650 м), становить 10 га. Усього виявлено близько 180 особин, нерівномірно розподілених між локусами. За віковою структурою досліджена популяція виду належить до нормального типу 3 правостороннім віковим спектром. Усі досліджені в 2018 р. особини, скоріш за все, були однорічниками, причому більшість 3 них досягла генеративного стану; зазвичай, S. mucronata є або вважається багаторічником (Krechetovich, 1940; Barbarych, 1987). Цікавою особливістю популяції є іiї висока динамічність. Під час ретельних обстежень у 2018 р. нам не вдалося виявити жодної особини $S$. mucronata в місцях, де ми його відмічали в 2016 р. (локуси № 1-3), натомість виявили 2 нові, розташовані неподалік, (локуси № 4, 5). Причому локус № 4 ми відвідували неодноразово в 2008-2016 pр., і тому впевнені, шо раніше $S$. mucronata тут не траплявся. Таким чином, рослини раптово з'являються у вологих зниженнях і так само раптово зникають, або ж проростають, вегетують не кожного року. Ймовірно, ця популяція $€$ значно чисельнішою, що й дало їй можливість утримуватися тут, принаймні, протягом більше восьми десятиліть. Подібних вологих знижень на Козачелагерській арені в котловинах видування серед пісків дуже багато - десятки тисяч. Хоча, скоріш за все, рослина є досить рідкісною, оскільки iii не вдавалося виявити тут раніше.

Місцезнаходження 2. Херсонська обл., Каланчацький р-н, околиця с. Гаврилівка Друга, рисове поле, 20.09.2012. Leg. \& Det. Мойсієнко I.I. (LWKS). Shoenoplectiella mucronata був виявлений на опіллі рисового чеку, в угрупованнях класу Oryzetea sativae Miyawaki 1960. Окрім Oryza sativa L. поряд росли Schoenoplectiella supina та Oryza sativa f. rubra (Blanco) Makino. Слід зазначити, що S. mucronata тут досить рясно представлений по периметру поля протягом кількох десятків метрів.

Таким чином, на сьогодні в Україні достовірно відомо два місцезнаходження $S$. mucronata, одне з яких розташовано в природних умовах у центрі Козачелагерської арени, інше - на рисових полях, у чітко виражених синантропних умовах. За результатами аналізу літературних даних, досліджуваний вид відомий як сегетальний ще 3 двох подібних місцезнаходжень.

У зв'язку із цим виникає питання статусу S. mucronata в складі флори України. Не можна виключити, що цей вид є заносним на території 
країни, або, можливо, у нас представлені як аллохтонні, так і автохтонні його популяції. Принаймні, поки що бракує достатньо даних для підтвердження його адвентивного статусу. Популяція $S$. mисronata в центрі Козачелагерської арени є відрізаною майже на 10 км від антропогенних об'єктів, до того ж, рослина була відома тут ще з 1932 року, тобто до початку інтенсивного використання військового полігону та будівництва на цій арені Новокаховського рибоводного заводу частикових риб. Тому питання щодо статусу $S$. mucronata у складі флори України є відкритим.

Дослідження були підтримані Шведським Науковим Комітетом (Vetenskapsrådet), проект No 2012-06112.

\section{СПИСОК ПОСИЛАНЬ}

Babayants O.V., Nepliy L.V. 2014. Naukovi pratsi Instytutu bioenerhetychnykh kultur $i$ tsukrovykh buryakiv, 20: 11-16. [Бабаянц О.В., Неплий Л.В. 2014. Эффективность гербицидов против разновидностей ежовниковых (Echinochloa) и камыша остроконечного (Scirpus mucronatus) в посевах риса в южной Степи Украины. Наукові праці Інституту біоенергетичних культур і иукрових буряків, 20: 11-16].

Banaś B., Kruk J. 2014. Schoenoplectus mucronatus. In: Polish Red Data Book of Plants. Pteridophytes and flowering plants. Eds R. Kaźmierczakowa, K. Zarzycki, Z. Mirek. Kraków: Instytut Ochrony Przyrody PAN, pp. 663-664.

Barbarych A.I. 1987. Schoenoplectus. In: Opredelitel vysshyh rasteniy Ukrainy. Ed. Yu.N. Prokudin. Kiev: Naukova Dumka, pp. 418-419. [Барбарич А.И. 1987. Schoеnoplectus. В кн.: Определитель высших растений Украины. Ред. Ю.Н. Прокудин. Киев: Наукова думка, с. 418-419].

Barbarych A.I. 1965. Schoenoplectus. In: Vyznachnyk Roslyn Ukrainy. Ed. D.K. Zerov. Kyiv: Urozhay, pp. 116-117. [Барбарич A.I. 1965. Schoenoplectus. В кн.: Визначник рослин Украӥни. Відпов. ред. Д.К. Зеров. Київ: Урожай, с. 116-117].

Bilz M., Kell S.P., Maxted N., Lansdown R.V. 2011. European Red List of Vascular Plants. Luxembourg: Publications Office of the European Union, $\mathrm{x}+130 \mathrm{pp}$.

Casper S.J., Krausch H.D. 1980 Süsswasserflora von Mitteleuropa. Bd. 23. Pteridophyta und Anthophyta. Stuttgart: Gustav Fischer Verlag, 403 S.

Danylyk I.M. 2009. Schoenoplectus mucronatus. In: Chervona knyha Ukrainy. Roslynnyi svit (Red Data Book of Ukraine. Plant Kingdom). Ed. Ya.P. Didukh. Kyiv: Globalconsulting, p. 110. [Данилик I.M. 2009. Schoenoplectus mucronatus. В кн.: Червона книга України. Рослинний світ. Ред. Я.П. Дідух. Київ: ГлобалконсалТинг, с. 110].

Danylyk I.M. 2012. Ukrainian Botanical Journal, 69(3): 337-352. [Данилик I.M. 2012. Система родини $C y$ - peraceae Juss. флори України. Український ботанічний жсурнал, 69(3): 337-352].

Danylyk I.M., Olshanskyi I.G., Zhygalova S.L. 2017. A new nomenclatural combination in Schoenoplectiella (Cyperaceae). Phytotaxa, 299(1): 138-140. https://doi. org/10.11646/phytotaxa.299.1.14

DeBerry D.A., McGoff N., Zinn N.D. 2010. Virginia: an account of Schoenoplectus mucronatus (L.) Palla in Virginia with comments on species introductions in wetland mitigation sites. Castanea, 75(4): 503-505. https://doi. org/10.2307/41058098

Dudchenko V.V., Dudchenko T.V. 2011. Zroshuvalne zemlerobstvo, 56: 72-78. [Дудченко В.В., Дудченко Т.В. 2011. Методи обліку та контролю чисельності бур'янів на посівах рису. Зрошувальне землеробство, 56: 72-78].

Egorova T.V. 1976. Cyperaceae. In: Flora evropeiskoy chasti SSSR, vol. 2. Ed. An.A. Fedorov. Leningrad: Nauka, pp. 83-219. [Егорова Т.В. 1976. Сурегасеае. В кн.: Флора европейской части СССР, т. 2. Лениград: Наука, c. 83-219].

Egorova T.V. 2005. Novosti sistematiki vysshikh rasteniy, 37: 49-79. [Егорова Т.В. 2005. Таксономический обзор рода Schoenoplectus (Reihenb.) Palla (Cyperaceae) флоры Северной Евразии. Новости систематики высших растений, 37: 49-79].

Fischer A.J., Strong G.L., Shackel K., Mutters R.G. 2010. Temporary drought can selectively suppress Schoenoplectus mucronatus in rice. Aquatic Botany, 92(4): 257-264. https://doi.org/10.1016/j.aquabot.2010.01.003

Govaerts R., Jimenez-Mejias P., Koopman J., Simpson D., Goetghebeur P., Wilson K., Egorova T., Bruhl J. 2018. World Checklist of Cyperaceae. Facilitated by the Royal Botanic Gardens, Kew. Available at: http://wcsp. science.kew.org (Accessed 1 October 2018).

Hayasaka E. 2012. Delineation of Schoenoplectiella Lye (Cyperaceae), a genus newly segregated from Schoenoplectus (Rchb.) Palla. Japanese Journal of Botany, 87: 169-186.

Jung J., Choi H.K. 2010. Systematic rearrangement of Korean Scirpus L. s. 1. (Cyperaceae) as inferred from nuclear ITS and chloroplast $r b c \mathrm{~L}$ sequences. Journal of Plant Biology, 53(3): 222-232. https://doi.org/10.1007/ s12374-010-9109-8

Krechetovich V.I. 1940. Scirpus. In: Flora URSR, vol. 2. Kyiv: Vyd-vo AN URSR, pp. 401-417. [Кречетович B.I. 1940. Scirpus. У кн.: Флора УРСР, т. 2. Київ: Вид-во AH УРCP, c. 401-417].

Lansdown R.V. 2013. Schoenoplectus mucronatus. In: The IUCN Red List of Threatened Species: e. T164086A13553540. Available at: https:// doi.org/ 10.2305 / I U C N. UK. 2013 - 1. RLT S. T164086A13553540.en. (Accessed 25 September 2018).

Lye K.A. 2003. Schoenoplectiella Lye, gen. nov. (Cyperaceae). Lidia, 6(1): 20-29.

Marchold K., Hindak F. 1998. Checklist of Non-Vascular and Vascular Plants of Slovakia. Eds K. Marchold, F. Hindak. Bratislava: VEDA, Vydavatel'stvo Slovenskej Akadémie Vied, $687 \mathrm{pp}$. 
Pignotti L. 2003. Scirpus L. and related genera (Cyperaceae) in Italy. Webbia, 58(2): 281-400.

Popov M.G. 1950. Schoenoplectus. In: Vyznachnyk Roslyn Ukrainy. Ed. M.V. Klokov. Kyiv, Kharkiv: Derzhavne vyd-vo silskogospodarskoi lit., pp. 803-804. [Попов М.Г. 1950. Schoenoplectus. У кн.: Визначник рослин України. Ред. М.В. Клоков. Київ; Харків: Держ. вид-во с-г. літ., с. 803-804].

Roskov Y., Ower G., Orrell T., Nicolson D., Bailly N., Kirk P.M., Bourgoin T., De Walt R.E., Decock W., De Wever A., Nieukerken E. van, Zarucchi J., Penev L.E. 2018. Species 2000 \& ITIS Catalogue of Life, $24^{\text {th }}$ September 2018. Digital resource at www.catalogueoflife.org/ col. Species 2000: Naturalis, Leiden, the Netherlands.

Rybak M., Gąbka M., Pęczuła W. 2016. A new locality of endangered bog bulrush Schoenoplectiella mucronata
(Cyperaceae) in the Eastern Poland. Steciana, 20(1): 1519. https://doi.org/10.12657/steciana.020.003

Shiels D.R., Hurlbut D.L., Lichtenwald S.K., Monfils A.K. 2014. Monophyly and phylogeny of Schoenoplectus and Schoenoplectiella (Cyperaceae): evidence from chloroplast and nuclear DNA sequences. Systematic Botany, 39(1): 132-144. https://doi.org/10.1600/036364414X678198

Smith S.G. 2002. Schoenoplectus. In: Flora of North America north of Mexico, vol. 23. Flora of North America Editorial Committee (ed.). New York; Oxford, pp. 44-60.

Рекомендує до друку

Надійшла 18.12.2018

I.А. Коротченко 


\title{
A new find of Arabidopsis neglecta (Brassicaceae) in the Svydovets Massif (Ukrainian Carpathians)
}

\author{
Clemens PACHSCHWÖLL, Tetiana PACHSCHWÖLL \\ Department of Botany and Biodiversity Research, University of Vienna \\ 14 Rennweg, Vienna 1030, Austria \\ clemens.pachschwoell@univie.ac.at \\ tetiana.pachschwoell@univie.ac.at
}

\begin{abstract}
Pachschwöll C., Pachschwöll T. 2019. A new find of Arabidopsis neglecta (Brassicaceae) in the Svydovets Massif (Ukrainian Carpathians). Ukrainian Botanical Journal, 76(1): 60-66.

Abstract. A new population of the Pancarpathian endemic species Arabidopsis neglecta was discovered in the Svydovets Massif at Komyn in 2018. It is the fifth population known so far for the Svydovets. A short description of the subalpine-alpine scree habitat (Rumici scutati-Rhodioletum roseae) is given. Many of the co-occuring species are listed in the Red Data Book of Ukraine (2009); however, A. neglecta is not included in the current edition of the Red Data Book of Ukraine. Though, its micropopulations on steep slopes of glacial cirques are highly vulnerable due to climate change and some other factors. Keywords: Cardaminopsis neglecta, Carpathian Biosphere Reserve, floristic record, rare species, Ukraine
\end{abstract}

Пахшвьоль К., Пахшвьоль Т. Нова знахідка Arabidopsis neglecta (Brassicaceae) на території масиву Свидовець (Українські Карпати). Український ботанічний журнал, 2019, 76(1): 60-66.

Реферат. Нова популяція карпатського ендеміка Arabidopsis neglecta була виявлена на г. Комин на території Свидовецького масиву Карпатського біосферного заповідника в 2018 р. Це п'ята популяція цього виду, виявлена на даний час в межах масиву Свидовець. Подано стислий опис субальпійсько-альпійського оселища (Rumici scutatiRhodioletum roseae) на щебнистому схилі. На відміну від $A$. neglecta, більшість видів цього угруповання включені в Червону книгу України (2009). Відмічено, що мікропопуляції даного виду на крутих схилах гляціальної арени перебувають під значною загрозою через зміни клімату.

Ключові слова: Карпатський біосферний заповідник, рідкісний вид, флористична знахідка, Україна, Cardaminopsis neglecta

\section{Introduction}

Arabidopsis neglecta (Schult.) O'Kane \& Al-Shehbaz (= Cardaminopsis neglecta (Schult.) Hayek, Arabis neglecta Schult.) is a Pancarpathian endemic species occurring in Poland, Slovakia, Romania and Ukraine (Marhold, 2011; Hurdu etal., 2012; Kliment etal., 2016). It grows in subalpine to alpine screes of intermediate to siliceous bedrock like sandstone flysch and crystalline schists (Sychowa, 1985; Chopyk, Fedoronchuk, 2015; Bartók et al., 2016). For the Ukrainian Carpathians, it has been considered as "Vulnerable" (VU) and "Data Deficient" (DD) by Malinovski et al. (2002), or even as "Endangered" (EN) by Kricsfalusy and Budnikov (2007), but has not been included later in the $3^{\text {rd }}$ edition of the Red Data Book of Ukraine (Chervona knyha..., 2009). As pointed out by Kobiv (2011, 2017, 2018), this perennial, short-lived glareophyte is definitely a C C. PACHSCHWÖLL, T. PACHSCHWÖLL, 2019 rare and threatened mountain species of the Ukrainian Carpathians where it occurs in the following mountain ranges: Chornohora, Svydovets, Marmarosh, and Chyvchyny Mts. (Kotov, 1953; Malinovski et al., 2002; Bedei, 2006; Chopyk, Fedoronchuk, 2015; Novikoff, Hurdu, 2015).

In the Svydovets Massif, only four populations have been known so far (Fig. 1). The first one can be found in a famous glacial cirque (c. $48^{\circ} 13^{\prime} 08^{\prime \prime} \mathrm{N}, 24^{\circ} 14^{\prime} 17^{\prime \prime} \mathrm{E}$ ) below Mt. Blyznytsia Velyka and Mt. Blyznytsia Mala that is part of the Carpathian Biosphere Reserve and harbours several rare high-mountain species, such as Antennaria carpatica (Wahlenb.) Bluff \& Fingerh., Hedysarum hedysaroides (L.) Schinz \& Thell, Veronica alpina L., Erigeron alpinus and Oreochloa disticha (Wulfen) Link; the latter two are considered extinct at this locality (Klášterský, 1929; Domin, 1930; Kobiv, 2017). The second population was reported from Mt. Drahobrat (c. $48^{\circ} 14^{\prime} 04^{\prime \prime} \mathrm{N}, 24^{\circ} 13^{\prime} 58^{\prime \prime} \mathrm{E}$ ) by Margittai (1935: 89); it 


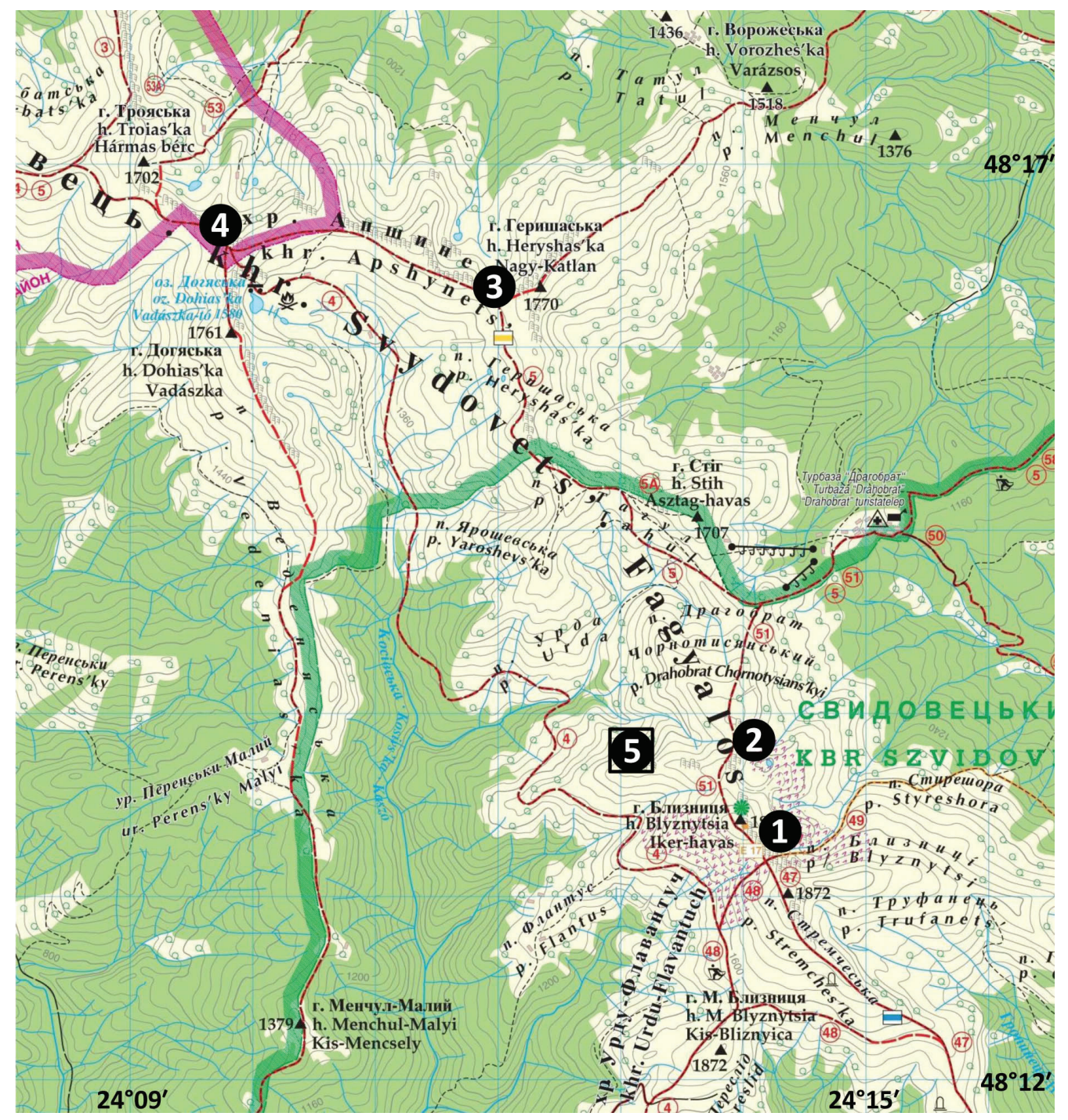

Fig. 1. Distribution of Arabidopsis neglecta in the Svydovets Massif (Ukrainian Carpathians). Populations 1-5 according to the text. The newly discovered population no. 5 at Komyn is emphasized with a black square. Green line: boundary of the Carpathian Biosphere Reserve. Purple Line: boundary of the districts Rakhiv and Tiachiv. Modified from: A Máramarosihavasok turistatérképe, 2. Kiadás, 1 : 50 000, Kárpátia Térképmühely Ktf. 2008

lies within a part of the Carpathian Biosphere Reserve but is now unconfirmed. The third one was reported also by Margittai (1935: 89) for Mt. Gereshaska [Heryshas'ka] (c. 48 $16^{\prime} 17^{\prime \prime} \mathrm{N}, 24^{\circ} 12^{\prime} 06^{\prime \prime} \mathrm{E}$ ) and could be considered confirmed by Chopyk (herbarium voucher in KW). The fourth locality at Mt. Trojaska/polonyna Apshynets $\left(48^{\circ} 16^{\prime} 38.7^{\prime \prime} \mathrm{N}, 24^{\circ} 09^{\prime} 36.5^{\prime \prime} \mathrm{E}, 1640 \mathrm{~m}\right.$ a.s.1., NE-exposed) was discovered only recently by Kobiv et al. (2009) and is very close to the previous one; see also Kobiv (2011) for population characterization.

\section{Material and methods}

During botanical fieldwork in the Svydovets Massif, a new population of Arabidopsis neglecta was discovered in a cirque at Komyn, c. $1.2 \mathrm{~km} \mathrm{NW}$ of the summit of Mt. Blyznytsia Velyka (no. 5 in Fig. 1). There, a handful of fruiting and vegetative individuals were growing in a scree microsite of a steep NW-exposed cliff. Due to the rarity of the species, we refrained from collecting herbarium specimens but documented its occurrence with photographs. The identification of $A$. neglecta was later confirmed with literature (Kotov, 1953; Jávorka, 


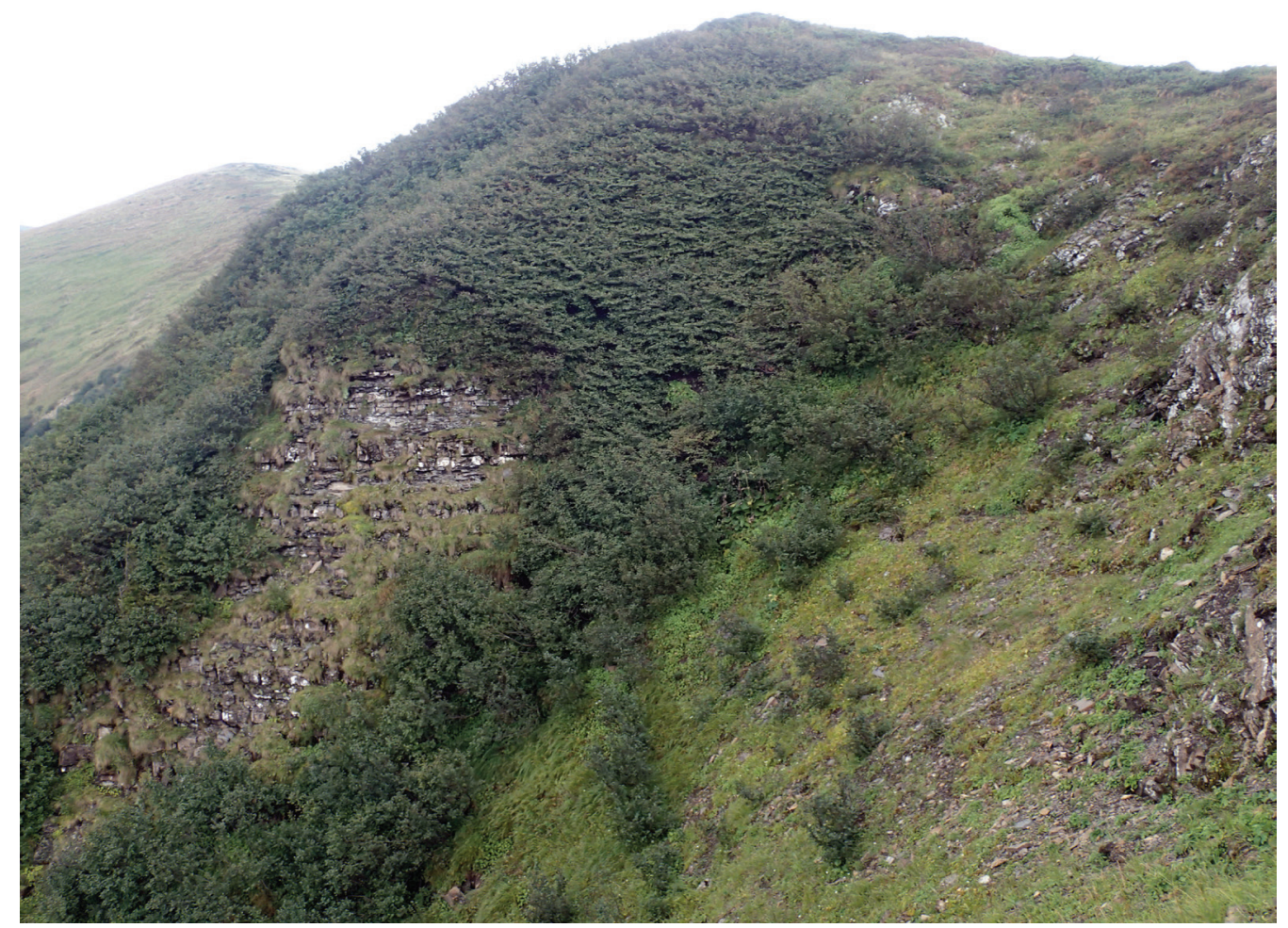

Fig. 2. Habitat of Arabidopsis neglecta at Komyn (Svydovets Massif, Ukrainian Carpathians) where this species grows at the bottom of a steep cliff surrounded by Alnus alnobetula (A. viridis). Photo by Clemens Pachschwöll, 22 August 2018

Csapody, 1979; Sychowa, 1985; Chopyk, Fedoronchuk, 2015) and by a specialist. GPS coordinates (WGS84) with an accuracy of c. $5 \mathrm{~m}$ as well as the altitude were determined with a Holux M-241 GPS logger. If not stated otherwise, nomenclature and taxonomy of taxa mentioned in this paper follow Euro+Med (2006-).

\section{Results and discussion}

Location, ecological characteristics and status of the newly discovered population of Arabidopsis neglecta in the Svydovets Massif

In the following, we present the exact location, ecological characteristics and accompanying species, see also Fig. 1-3.

Arabidopsis neglecta: Ukraine, Zakarpatska Oblast, Rakhiv Raion (District), Svydovets Massif, Carpathian Biosphere Reserve, north-exposed cirque at Komyn c. $1.2 \mathrm{~km}$ NW of Mt. Blyznytsia Velyka peak, $48^{\circ} 13^{\prime} 40.4^{\prime \prime} \mathrm{N}$, $24^{\circ} 13^{\prime} 01.4^{\prime \prime} \mathrm{E}, 1670 \mathrm{~m}$ a.s.1.

Habitat (see Fig. 2): bottom of a steep (c. $70^{\circ}$ ), NWexposed cliff of calcium-containing flysch surrounded by shrubs of Alnus alnobetula (Ehrh.) K. Koch (= A. viridis (Chaix) DC.). It harbours stairlike, densely vegetated outcrops as well as also poorly vegetated microsites.

Accompanying species: Achillea oxyloba subsp. schurii (Sch. Bip.) Heimerl, Asplenium viride Huds., Calamagrostis villosa (Chaix) J.-F. Gmel., Campanula kladniana (Schur) Witasek, Cerastium alpinum L., Doronicum columnae subsp. carpaticum (Griseb. \& Schenk) Soó (=D. carpaticum (Griseb. \& Schenk) Nyman, see Pachschwöll, 2014), Festuca amethystina subsp. orientalis Krajina ( $=F$. inarmata Schur), Galium anisophyllon Vill., Parnassia palustris L., Phyteuma orbiculare L., Primula elatior (L.) L. (incl. Primula poloninensis (Domin) Fed.), Rhodiola rosea L., Rumex scutatus L., Saussurea alpina (L.) DC., Sabulina verna (L.) Rchb. (= Minuartia verna (L.) Hiern., incl. M. gerardii (Willd.) Hayek and M. pauciflora (Kit. ex Kanitz) Dvořaková, see Fedoronchuk \& Mosyakin, 2016), Saxifraga paniculata Cav., Selaginella selaginoides (L.) Schrank \& Mart., Thymus pulcherrimus Schur, Viola biflora $\mathrm{L}$. and others.

Obs.: Clemens Pachschwöll \& Tetiana Pachschwöll, 22 August 2018; ref. (on digital images): Filip Koláŕ, 17 September 2018. 


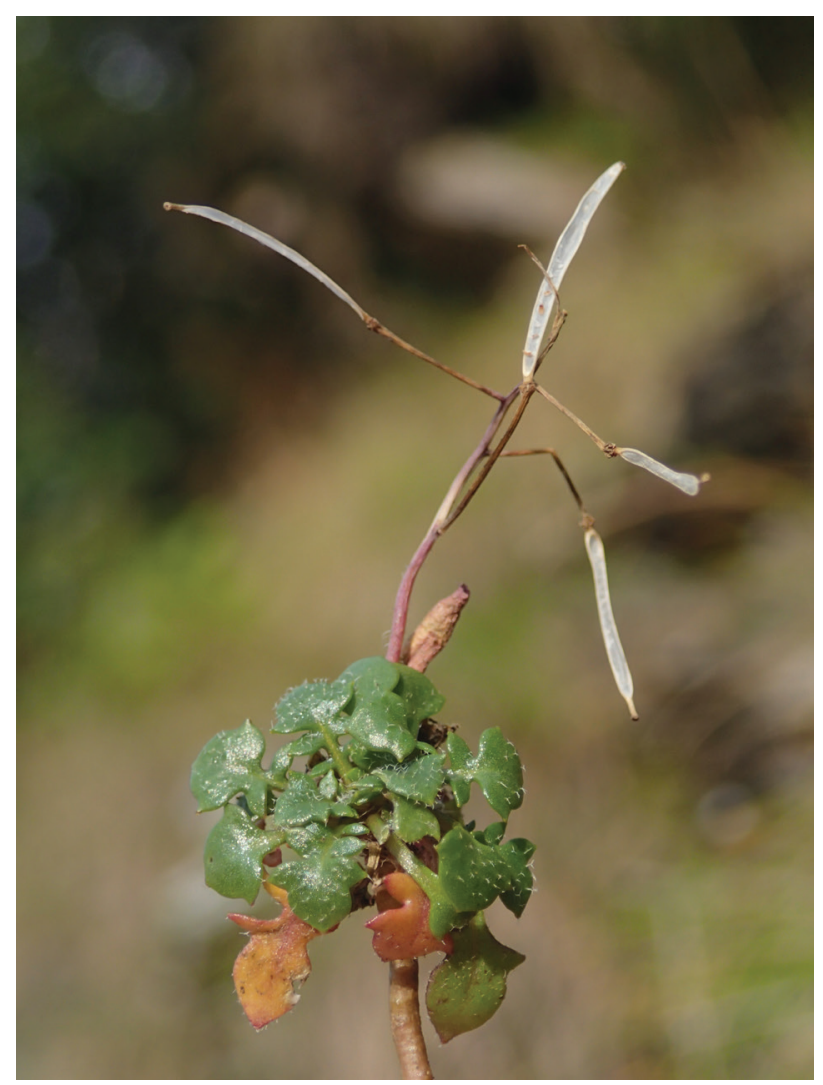

Fig. 3. Arabidopsis neglecta: close-up of a fruiting individual. Photo by Clemens Pachschwöll, 22 August 2018

Arabidsopis neglecta grows here in scree microsites of the association Rumici scutati-Rhodioletum roseae Malinovsky et al. 1991 from alliance PapaveroThymion pulcherrimi I. Pop 1968 (Solomakha, 2008), a phytocoenosis known from other parts of the Svydovets Massif, like Mt. Drahobrat (Malinovskiy, Krichfalusy, 2000; Didukh et al., 2016; Solomakha, 2008; Kobiv et al., 2009).

The botanical importance of calcicole to intermediate subalpine-alpine habitats at the Komyn Cirque is expressed by the number and abundance of threatened species occurring there (Bedei, 2006; Kyyak et al., 2016). According to the Red List for the Ukrainian Carpathians by Kricsfalusy and Budnikov (2007), two taxa (Cerastium eriophorum, Festuca amethystina subsp. orientalis) are vulnerable (VU), six (Achillea oxyloba subsp. schurii, Doronicum columnae subsp. carpaticum, Galium anisophyllon, Rhodiola rosea, Sabulina verna, Saussurea alpina) are endangered (EN), and one (Selaginella selaginoides) is critically endangered (CR). According to the Red Data Book of Ukraine (Chervona knyha..., 2009), Achillea oxyloba subsp. schurii, Campanula kladniana, Sabulina verna (listed as Minuartia pauciflora) and Saussurea alpina are rare and Rhodolia rosea and Selaginella selaginoides are vulnerable. It is worth mentioning, that Komyn harbours the only known population of Saussurea alpina in the Svydovets Massif, which was originally (although erroneously) published as Saussurea discolor (Willd.) DC. (Kardash, Kyyak, 1991). In the Ukrainian Carpathians, Saussurea alpina is a rare arctic-alpine species otherwise known only from the Chornohora (Kyyak, 2009; Cherepanyn, 2017). Another noteworthy species not mentioned in any Red List is the PanCarpathian endemic Thymus pulcherrimus (Novikoff, Hurdu, 2015; Kliment et al., 2016). In Ukraine it is only known from a dozen populations, from Mt. Blyznytsia and Mt. Drahobrat in the Svydovets Massif as well as from the Chornohora and Chyvchyny (Chopyk, Fedoronchuk, 2015; Nachychko, Honcharenko, 2017).

Due to several factors, micropopulations of Arabidsopis neglecta (Fig. 3) in steep slopes of glacial cirques are highly endangered. Very likely, there is no gene flow between them as they are separated geographically in an "island-like" fashion. During a ten-year period of monitoring, Alnus alnobetula (A. viridis) has overtaken next to Saussurea alpina at Komyn, decreasing in suitable microhabitats for pioneer and early-successional cold-dwelling species such as the newly discovered A. neglecta (Kyyak et al., 2016). Less snow cover, less erosion due to snowpack shift, less humidity and prolonged vegetation periods are responsible for the trend demonstrating that low-competitive glareophytes such as A. neglecta are threatened by overgrowth of subalpine scrubs and dwarf shrubs (Didukh et al., 2016; Kobiv, 2017). Due to climate change, this narrow-range taxon is in general decline in other monitored populations of the Ukrainian Carpathians (Kobiv, 2017). In the Chornohora, one monitored population of $A$. neglecta at Mt. Brebeneskul has been gradually shrinking during a 15 -year period (Kobiv, 2018), rendering the discovery of a new population valuable. The unprotected populations from Mt. Gereshaska [Heryshas'ka] (Margittai, 1935) and Mt. Trojaska/polonyna Apshynets (Kobiv et al., 2009) are probably the most endangered ones. They are located c. 0.5 and $1 \mathrm{~km}$ aside, respectively, the projected roads and hotels of the planned gigantomaniac ski and spa resort "Svydovets" (Bedernichek, 2017; https:// freesvydovets.org) which might cause urbanization, pollution and even destruction of the high mountain habitats in the north-central part of the Svydovets 
Massif (Kagalo et al., 2018). All these facts support the categorization "endangered" (EN) for A. neglecta in the Ukrainian Carpathians, as used by Kricsfalusy and Budnikov (2007).

\section{Arabidopsis neglecta in the Carpathians - recent publications and outlook}

The biological knowledge on $A$. neglecta in the Ukrainian Carpathians is scarce and its detailed distribution is still not well known. In the Western and Southern Carpathians (Slovakia and Romania), two cytotypes of $A$. neglecta do exist (Schmickl et al., 2012; Hohmann et al., 2014; Kolář et al., 2016b), A. neglecta subsp. neglecta $(2 n=16)$ and the taxon informally (provisionally) named "subsp. robusta" $(2 n=32)$. For the Ukrainian Carpathians, no cytological or genetic data is available so far (Schmickl et al., 2012; Hohmann et al., 2014; Rice et al., 2014; Koláŕ et al., 2016a, b). More detailed floristic investigations in suitable habitats of the Ukrainian Carpathians could lead to discoveries of further populations, as it has been done in the Southeastern Carpathians by Bartók et al. (2016). Due to the fact that $A$. neglecta is sometimes confused with more common species Arabidopsis arenosa (L.) Lawalrée and A. halleri (L.) O'Kane \& Al-Shehbaz, a critical revision of so far unconfirmed records like that from the Gorgany (Ziman, Tyukh, 2008) - which is not accepted by Chopyk and Fedoronchuk (2015), Novikoff and Hurdu (2015), and Bartók et al. (2016) - should be undertaken. Recent genomic studies showed that the alpine eco- and morphotype of A. neglecta evolved repeatedly from lowland $A$. arenosa in the Carpathians (Kolář et al., 2017, Monnahan et al., 2019), rendering a future reclassification necessary. Regardless of any future classification change, either as an infraspecific entity or just a synonym of $A$. arenosa, - a taxon more widespread in the Ukrainian Carpathians (Kotov, 1953; Sychowa, 1985; Chopyk, Fedoronchuk, 2015) and well known from the Svydovets Massif (Klášterský, 1929), the numerous rare alpine plant species mentioned for Komyn justify this report which should stimulate future research on the genus Arabidopsis in the Ukrainian Carpathians.

\section{Acknowledgments}

We are grateful to Filip Koláŕ (Charles University, Prague) for confirming our identification and to Andriy Novikov (State Natural History Museum, NAS of Ukraine, Lviv) for his help in providing rare literature. Useful comments of Dmitry German (Heidelberg University, Heidelberg, Germany, and
Altay State University, Barnaul, Russia) and Yuriy Kobiv (Institute of Ecology of the Carpathians, NAS of Ukraine, Lviv) provided in their open reviews are greatly appreciated, as well as editorial comments of Sergei Mosyakin (M.G. Kholodny Institute of Botany, NAS of Ukraine, Kyiv).

\section{REFERENCES}

Bartók A., Hurdu B.-I., Szatmari P.-M., Ronikier M., Puşcaş M., Novikoff A., Bartha L., Vonica G. 2016. New records for the high-mountain flora of the Făgăraş Mts. (Southern Carpathians) with discussion on ecological preferences and distribution of studied taxa in the Carpathians. Contributii Botanice Univitâtea "Babes-Bolyai" Cluj-Napoca, 51: 77-153.

Bedei M.I. 2006. Blyznytsi-Drahobrat (flora, vegetation, conservation). Uzhhorod: Lira, 108 pp. [Бедей M.I. 2006. Близниці-Драгобрат (флора, рослинність, охорона). Ужгород: Ліра, 108 с.].

Bedernichek T. 2017. Alpine tundra of the Krkonoše and Carpathian mountains. Regensburg: EUROPARC Federation \& Alfred Toepfer Foundation, 36 pp. Available at: http://www.europarc.org/wp-content/ uploads/2018/04/Alpine-Tundra_Tymur-Bedernichek_ Report.pdf (Accessed 20 January 2019 ).

Cherepanyn R.M. 2017. Artic-alpine plant species of the Ukrainian Carpathians. Ivano-Frankivsk: Publishing House of the Precarpathian National University, 92 pp. [Черепанин Р.М. 2017. Аркто-альпійські види рослин Українських Карпат. Івано-Франківськ: Вид-во Прикарпат. нац. ун-ту, 92 с.].

Chervona knyha Ukrainy. Roslynnyi svit (Red Data Book of Ukraine. Plant Kingdom). 2009. Ed. Ya.P. Didukh. Kyiv: Globalkonsaltyng, 912 pp. [Червона книга України. Рослинний світ. 2009. Ред. Я.П. Дідух. Київ: Глобалконсалтинг, 912 с.].

Chopyk V.I., Fedoronchuk M.M. 2015. Flora Ucrainae Carpaticae. Ternopil: Terno-graph, 712 pp. [Чопик B.I., Федорончук М.М. 2015. Флора Українських Kарпат. Тернопіль: Терно-граф, 712 с.].

Didukh Ya.P., Chorney I.I., Budzhak V.V. 2016. Climatogenic changes of plant life of the Ukrainian Carpathians. Eds Ya.P. Didukh, I.I. Chorney. Chernivtsi: DrukArt, 280 рр. [Дідух Я.П., Чорней І.І., Буджак В.В. 2016. Кліматогенні зміни рослинного світу Українських Kapnam. Ред. Я.П. Дідух, I.I. Чорней. Чернівці: Друк Арт, 280 c.].

Domin K. 1930. Šimanův kotel na Svidovci v Podkarpatské Rusi. Vèstník Královské české společnosti náuk, Třr. Mat.Př́r., 4: 1-20.

Euro+Med (2006-): Euro+Med PlantBase - the information resource for EuroMediterranean plant diversity. Available at: http://ww2.bgbm.org/EuroPlusMed/ (Accessed 20 January 2019).

Fedoronchuk M.M., Mosyakin S.L. 2016. Ukrainian Botanical Journal, 73(2): 134-143. [Федорончук M.M., Мосякін С.Л. 2016. Рід Minuartia s. 1. (Caryophyllaceae) у флорі Східної Європи: огляд номенклатурних змін у світлі нових молекулярно-філогенетичних даних. Український ботанічний журнал, 73(2): 134-143]. https://doi.org/10.15407/ukrbotj73.02.134 
Hohmann N., Schmickl R., Chiang T.-Y., Lučanová M., Kolář F., Marhold K., Koch M.A. 2014. Taming the wild: resolving the gene pools of non-model Arabidopsis lineages. BMC Evolutionary Biology, 14: 224. https://doi. org/10.1186/s12862-014-0224-X

Hurdu B.-I., Puşcaş M., Turtureanu P.D., Niketić M., Coldea G., Zimmermann N.E. 2012. Patterns of plant endemism in the Romanian Carpathians (South-Eastern Carpathians). Contributii Botanice Univitâtea "BabesBolyai" Cluj-Napoca, 47: 25-38.

Jávorka S., Csapody V. 1979. Ikonographie der Flora des südöstlichen Mitteleuropa. Budapest \& Stuttgart: Akadémiai Kiadó \& G. Fischer-Verlag, 703 pp.

Kagalo A., Kanarsky Y., Mykitchak T., Kovtoniuk, O., Kobiv Y., Kyyak V., Sytschak N., Bashta A.-T., Tsaryk J., Dykyy I., Shydlovskyy I., Reshetylo O. 2018. Visnyk Kyivskoho Universytetu im. Tarasa Shevchenka. Series Geografiya, 70(1): 35-46. [Кагало О., Канарський Ю., Микітчак Т., Ковтонюк О., Кобів Ю., Кияк В., Сичак Н., Башта А.-Т., Царик Й., Дикий I., Шидловський I., Решетило О. 2018. Природоохоронне значення території Центрального Свидовця (Українські Карпати). Вісник Киівського університетуту імені Тараса Шевченка. Серія Географія, 70(1): 35-46]. https://doi. org/10.17721/1728-2721.2018.70.6

Kardash Ya.V., Kyyak V.H. 1991. Nove mistseznakhodzhennya Saussurea discolor (Willd.) DC. In: Aktualni problemy vyvchennya fitobioty u zakhidnomu rehioni Ukrainy: Mater. konf. molodykh botanikiv m. Lvova. Lviv, pp. 5456. [Кардаш Я.В., Кияк В.Г. 1991. Нове місцезнаходження Saussurea discolor (Willd.) DC. У зб.: Актуальні проблеми вивчення фітобіоти у західному регіоні України: Матер. конф. молод. ботаніків м. Львова. Львів, с. 54-56].

Klášterský I. 1929. Ad floram Carpatorossicam additamenta critica I. Preslia, 8: 9-32.

Kliment J., Turis P., Janišová M. 2016. Taxa of vascular plants endemic to the Carpathian Mts. Preslia, 88: 19-76.

Kobiv Y.Y. 2011. Ukrainian Botanical Journal, 68(5): 635650. [Кобів Ю.Й. 2011. Периферійні популяції рідкісних видів рослин Українських Карпат. Український ботанічний журнал, 68(5): 635-650].

Kobiv Y. 2017. Response of rare alpine plant species to climate change in the Ukrainian Carpathians. Folia Geobotanica, 52: 217-226. https://doi.org/10.1007/ s12224-016-9270-Z

Kobiv Y. 2018. Trends in population size of rare plant species in the alpine habitats of the Ukrainian Carpathians under climate change. Diversity, 10(3): 62. https://doi. org/10.3390/d10030062

Kobiv Y., Prokopiv A., Helesh M., Borsukevich L. 2009. Visnyk Lvivskoho universytetu. Series Biology, 49: 63-82. [Кобів Ю., Прокопів А., Гелеш М., Борсукевич Л. 2009. Поширення, стан популяцій та характеристика оселищ рідкісних і загрожених видів рослин у північній частині Свидовця (Українські Карпати).
Вісник Львівського університету. Серія біологічна, 49: 63-82].

Kolář F., Fuxová G., Záveská E., Nagano A.J., Hyklová L., Lucanová M., Kudoh H., Marhold K. 2016. Northern glacial refugia and altitudinal niche divergence shape genome-wide differentiation in the emerging plant model Arabidopsis arenosa. Molecular Ecology, 25(16): 39293949. https://doi.org/10.1111/mec.13721

Kolář F., Lučanová M., Záveská E., Fuxová G., Mandáková T., Španiel S., Senko D., Svitok M., Kolník M., Gudžinskas Z., Marhold K. 2016. Ecological segregation does not drive the intricate parapatric distribution of diploid and tetraploid cytotypes of the Arabidopsis arenosa group (Brassicaceae). Biological Journal of the Linnean Society, 119: 673-688. https://doi.org/10.1111/ bij. 12479

Kolář F., Fuxová G., Knotek A., Záveská E., Marhold K. 2017. Phylogeography of Carpathian plants above and below the timberline - case study of two Arabidopsis species with pronounced altitudinal ecotypic variation. Studia Universitatis Babeş-Bolyai. Series Biologia. Spec. Issue, 62: 47.

Kotov M.I. 1953. Cruciferae. In: Flora URSR, vol. 5. Ed. M.V. Klokov. Kyiv: Ukr. RSR Acad. Sci. Publ., pp. 203429, p. 650. [Котов М.I. 1953. Cruciferae. В кн.: Флора Української РСР, т. 5. Ред. М.В. Клоков. Київ: Вид-во AH УРСР, c. 203-429, c. 650].

Kricsfalusy V., Budnikov G. 2007. Threatened vascular plants in the Ukrainian Carpathians: current status, distribution and Conservation. Thaiszia, 17: 11-32.

Kyyak V. 2009. Saussurea alpina. In: Chervona knyha Ukrainy. Roslynnyi svit (Red Data Book of Ukraine. Plant Kingdom). Ed. Ya.P. Didukh. Kyiv: Globalconsulting, p. 333. [Кияк В. 2009. Saussurea alpina. В кн.: Червона книга України. Рослинний світ. Ред. Я.П. Дідух. Київ: Глобалконсалтинг, с. 333].

Kyyak V., Shtupun V., Bilonoha V. 2016. Visnyk Lvivskoho universytetu. Series Biology, 74: 104-115. [Кияк В., Штупун В., Білонога В. 2016. Кліматогенні загрози популяціям рідкісних і ендемічних видів рослин високогір'я Українських Карпат. Вісник Львівського університету. Серія біологічна, 74: 104-115].

Malinovski K.A., Kricsfalusy V.V. 2000. High mountain vegetation. In: Vegetation of the Ukraine, vol. 1. Ed. V. Solomakha. Kyiv: Phytosociocentre, 230 pp. [Малиновський К.А, Крічфалушій В.В. 2000. Високогірна рослинність. В кн.: Рослинність України, т. 1. Ред. В.А. Соломаха. Київ: Фітосоціоцентр, 230 с.].

Malinovski K., Tsaryk Y., Kyyak V., Nesteruk Y. 2002. Rare, endemic, relict and marginally ranged plant species of the Ukrainian Carpathians. Lviv: Liga-Press, 76 рр. [Малиновський К., Царик Й., Кияк В., Нестерук Ю. 2002. Рідкісні, ендемічні, реліктові та погранично-ареальні види рослин Українських Карпат. Львів: Ліга-Прес, $76 \mathrm{c.}$.$] .$

Margittai A. 1935. A Körösmezei (Jaszinai) Pietrosz-havas flórája. Die Flora des Körösmezöér (Jasinaer) Pietros. Botanika közlemények, 32: 75-91.

Marhold K. 2011. Brassicaceae. In: Euro+Med Plantbase - the information resource for Euro-Mediterranean 
plant diversity. Available at: http://ww2.bgbm.org/EuroPlusMed/ (Accessed 20 January 2019).

Monnahan P., Kolář F., Baduel P., Sailer C., Koch J., Horvath R., Laenen B., Schmickl R., Paajanen P., Šámková G., Bohutínská M., Arnold B., Weisman C.M., Marhold M., Slotte T., Bomblies K., Yant L. 2019. Pervasive population genomic consequences of genome duplication in Arabidopsis arenosa. Nature Ecology \& Evolution, 3: 457-468. https://doi.org/10.1038/ s41559-019-0807-4.

Nachychko V., Honcharenko V. 2017. Visnyk Lvivskoho universytetu. Series Biology, 75: 35-47. [Начичко В., Гончаренко В. 2017. Ботаніко-географічна характеристика видів роду Thymus L. (Lamiaceae) у флорі західних регіонів України. Вісник Львівського університету. Серія біологічна, 75: 35-47].

Novikoff A., Hurdu B.-I. 2015. A critical list of endemic vascular plants in the Ukrainian Carpathians. Contributii Botanice Univitâtea "Babes-Bolyai" Cluj-Napoca, 50: 43-91.

Pachschwöll C. 2013. Lectotypification of Doronicum carpaticum (Griseb. \& Schenk) Nyman (Asteraceae), with some remarks on its distribution and taxonomy. Contributii Botanice Univitâtea "Babes-Bolyai" Cluj-Napoca, 48: 7-14.

Rice A., Glick L., Abadi S., Einhorn M., Kopelman N., Salman-Minkov A., Mayzel J., Chay O., Mayrose I. 2014. The Chromosome Counts Database (CCDB) - a community resource of plant chromosome numbers. New Phytologist, 206: 19-26. https://doi.org/10.1111/ nph.13191

Schmickl R., Paule J., Klein J., Marhold K., Koch M.A. 2012. The evolutionary history of the Arabidopsis arenosa complex: Diverse tetraploids mask the Western Carpathian center of species and genetic diversity. PLoSONE, 7(8): e42691. https://doi.org/10.1371/journal.pone.0042691.

Solomakha V.A. 2008. Syntaksonomiya roslynnosti Ukrainy. Tretye nablyzhennya. Kyiv: Phytosociocentre, 296 pp. [Соломаха В.А. 2008. Синтаксономія рослинності України. Третє наближсення. Київ: Фітосоціоцентр, 296 c.].

Sychowa M. 1985. Cardaminopsis (C.A.Maer) Hayek, Rzeżusznik. In: Flora Polski, Rośliny naczyniowe, vol. 4. Ed. A. Jasiewicz. Warszawa-Kraków: PWN, pp. 203-208.

Ziman S.M., Tyukh Y.Y. 2008. Ukrainian Botanical Journal, 65(4): 513-519. [Зиман С.М., Тюх Ю.Ю. 2008. Біоморфологічний аналіз рідкісних таксонів судинних рослин у флорі національного природного парку "Синевир". Український ботанічний журнал, 65(4): 513-519].

Recommended for publication by S.L. Mosyakin 


\title{
Serratula coronata (Asteraceae) - a new species record for the flora of Azerbaijan
}

\author{
Arzu Y. HUSEYNOVA, Parvin N. AGHAYEVA, Parvana Kh. QARAKHANI, Valida M. ALI-ZADE \\ Institute of Botany, National Academy of Sciences of Azerbaijan \\ Badamdar Highway 40, Baku AZ1004, Azerbaijan \\ vm_alizade@yahoo.com
}

Huseynova A.Y., Aghayeva P.N., Qarakhani P.Kh., Ali-zade V.M. 2019. Serratula coronata (Asteraceae) - a new species record for the flora of Azerbaijan. Ukrainian Botanical Journal, 76(1): 67-70.

Abstract. Serratula coronata (Asteraceae) is reported for the first time for the flora of Azerbaijan. The species was first found during the field surveys in 2012 in the forest edge near the village of Qonaqkend in Quba District of Azerbaijan, and later (in 2014) also discovered between Arafsa and Leketaq villages in the Nakhchivan Autonomous Republic. Data on distribution of species of Serratula sensu lato in the Caucasus are briefly reported and summarized. Diagnostic characters distinguishing $S$. coronata from other related taxa are provided. Plant communities with participation of $S$. coronata in Azerbaijan are characterized. Recent data on taxonomy of Serratula and related taxa are briefly discussed. Keywords: Asteraceae, Azerbaijan, biogeography, flora, Serratula, taxonomy

Гусейнова А.Й., Агаєва Р.Н., Гарахані Р.Х., Алі-заде В.М. Serratula coronata (Asteraceae) - новий вид для флори Азербайджана. Український ботанічний журнал, 76(1): 67-70.

Інститут ботаніки НАН Азербайджана

Бадамдарське шосе 40, Баку AZ1004, Азербайджан

Abstract. Serratula coronata (Asteraceae) вперше наводиться для флори Азербайджана. Цей вид був знайдений під час польових обстежень у 2012 р. на лісовій галявині біля с. Гонагкенд у Губинському районі Азербайджана, а пізніше (в 2014 р.) - також між с. Арафса і Лекетаг у Нахічеванській Автономній Республіці. В статті стисло викладено дані про поширення видів Serratula на Кавказі. Подано діагностичні ознаки, які відрізняють S. coronata від інших споріднених таксонів. Наведено характеристики угруповань рослин із участю $S$. coronata в Азербайджані. Отримані результати обговорюються у контексті сучасних даних про таксономію та філогенію Serratula і споріднених таксонів. Ключові слова: Азербайджан, поширення, систематика, флора, Asteraceae, Serratula

The family Asteraceae (Compositae, nom. altern.) was reported to be represented in the flora of Azerbaijan by ca. 580 species belonging to 125 genera (Agadjanov, 1961); however, the exact numbers of species and genera are subject to changes due to recent changes in taxonomy and nomenclature. Several genera and species of the family, such as Centaurea L., Pyrethrum Zinn. sensu stricto (now Tanacetum L. sensu lato), etc., were studied in Azerbaijan in detail (Askerova, 1970; Qusenova et al., 2013, 2014; Mustafayeva, 2013; Mustafayeva et al., 2017); however, some groups of the family are still insufficiently known in the country. In the $20^{\text {th }}$ century, seven species of Serratula $\mathrm{L}$. sensu lato were reported for the territory of Azerbaijan (Agadjanov, 1961): S. quinquefolia M.Bieb. ex Willd., S. coriacea Fisch. \& C.A.Mey., S. radiata (Waldst. \& Kit.) M.Bieb., S. transcaucasica (Bornm.) Sosn. ex Grossh., S. caucasica Boiss., S. xeranthemoides M.Bieb., and S. serratuloides (Fisch. \& C.A.Mey. ex DC.) Takht.

(C) A.Y. HUSEYNOVA, P.N. AGHAYEVA, P.Kh. QARAKHANI, V.M. ALI-ZADE, 2019
Eight species of Serratula were reported from the Caucasus, including $S$. coronata L., S. erucifolia (L.) Boriss., S. radiata, S. haussknechtii Boiss., S. coriacea, S. quinquefolia, S. serratuloides (Fisch. \& C.A.Mey.) Takht., and S. caucasica Boiss. Serratula coronata was mentioned in the Conspectus florae Caucasi (2008) for central and western parts of the Caucasus, but not for Azerbaijan, which is located in the Southern Caucasus. Of those species reported in the Conspectus, $S$. transcaucasica was synonymized with $S$. haussknechtii and $S$. xeranthemoides with $S$. erucifolia. Other species were recorded for Azerbaijan.

The concept of the genus has changed recently and all Azerbaijani species except one ( $S$. coriacea) were transferred to the genus Klasea Cass. Now they are recognized as Klasea quinquefolia (Willd.) Greuter \& Wagenitz (Serratula quinquefolia), K. radiata (Waldst. \& Kit.) Á. Löve \& D.Löve (S. radiata), K. haussknechtii (Boiss.) Holub (S. transcaucasica), K. caucasica (Boiss.) Greuter ( $S$. caucasica), K. erucifolia (L.) Greuter \& Wagenitz ( $S$. xeranthemoides), and $K$. serratuloides 

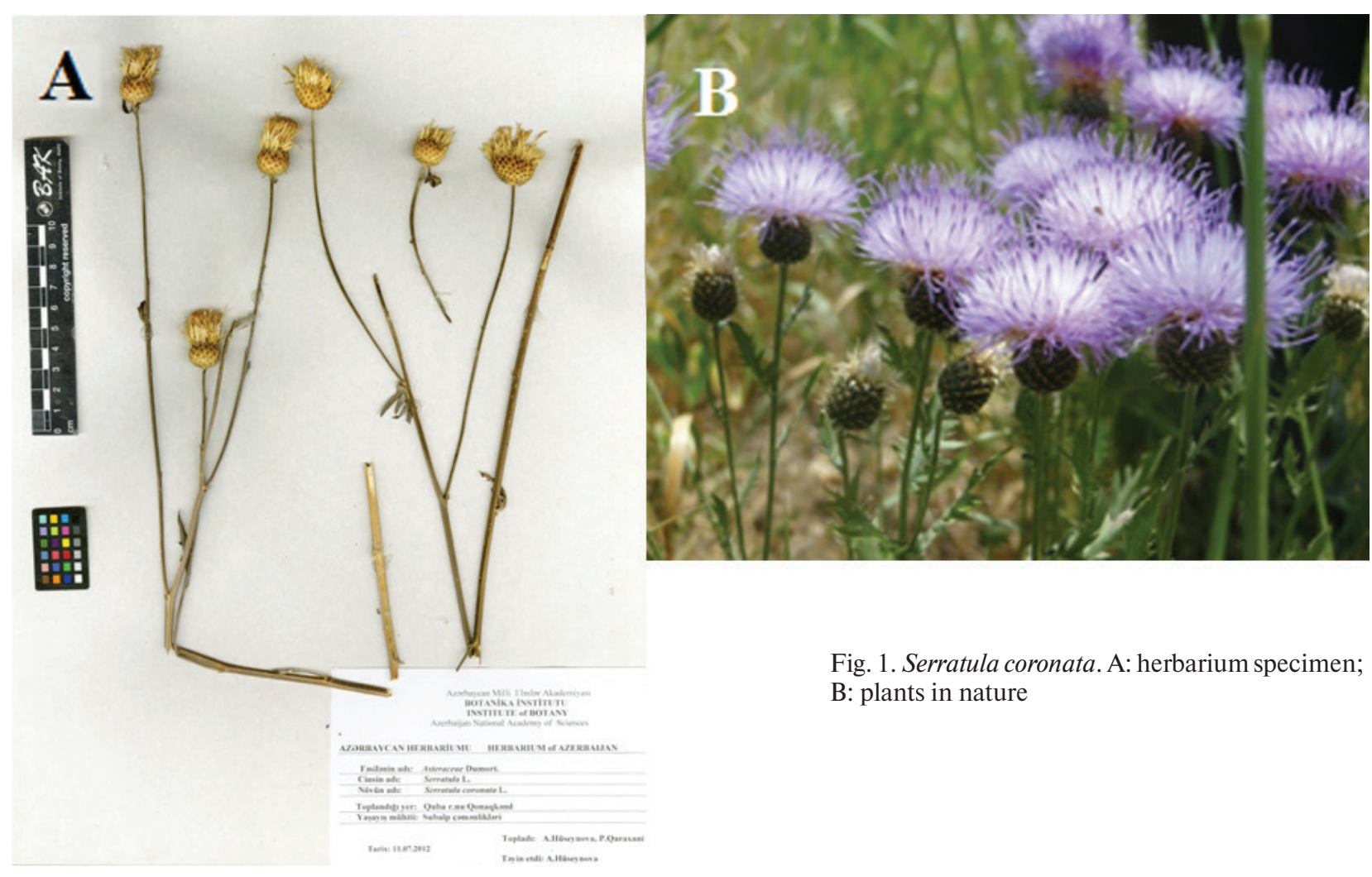

Fig. 1. Serratula coronata. A: herbarium specimen; B: plants in nature

(DC.) Greuter \& Wagenitz (S. serratuloides) (see Wagenitz, 1959, 1975; Wagenitz, Hellwig, 1996). Serratula coronata and $S$. erucifolia have not been yet reported from Azerbaijan.

Reliable diagnostic characters for identification of species of Serratula and Klasea include pollen types, chromosome numbers, along with arrangement of florets, seriate pappus, phyllaries, apendages, etc., but in general identification of species belonging to that group of Asteraceae is complicated. Eight pollen types were distinguished among taxa of the subtribe Centaureinae and, according to the pollen evolution, the genera Serratula, Crupina (Pers.) DC., Rhaponticoides Vaill., Psephellus Cass., Centaurea, and the Acrocentron and Jacea groups of Centaurea sensu lato were evolutionarily ranked based on their main pollen types by Wagenitz (1955). Later, Serratula, Crupina and Rhaponticoides were accepted as "primitive" (with mainly ancestral pollen characters), Psephellus (including P. dealbatus (Willd.) K.Koch = Centaurea dealbata Willd., and related taxa), the Centaurea Cyanus and Centaurea Montana groups - as intermediate, but the Acrocentron and Jacea groups of Centaurea - as advanced types.
The Serratula type with spiny pollen grains was placed in the evolutionarily basal (early-branching) part of the cladogram of Centaureinae (Garcia-Jacas et al., 2001).

Progress in taxonomy, beginning from the last decades of the $20^{\text {th }}$ century, especially due to molecular phylogenetic studies, brought more clarity to the taxonomic positions of genera, also necessitating numerous taxonomic changes and nomenclatural rearrangements within subtribes, tribes, and genera. Recent molecular phylogenetic studies indicated that the genus Serratula, as traditionally understood, is not a monophyletic group (Martins, Hellwig, 2005; Martins, 2006; Dogan et al., 2015). In particular, the segregate genus Klasea is currently recognized as distinct from Serratula sensu stricto (Ranjbar et al., 2015). However, the species $S$. coronata remains in the genus Serratula sensu stricto.

Herbarium specimens were collected in subalpine meadows of Qonaqkend village in Quba District, at elevation $1900 \mathrm{~m}$ above sea level [a.s.l.] (GPS coordinates $\mathrm{N} 41^{\circ} 12^{\prime} 03.8^{\prime \prime}$, E048 $13^{\prime} 21.7^{\prime \prime}$, collection date 11 August 2012) and between Arafsa and Leketaq villages in Nakhchivan Autonomous Republic of 
Azerbaijan at elevations $1700-1800 \mathrm{~m}$ a.s.l. (GPS coordinates $\mathrm{N} 41^{\circ} 05^{\prime} 546^{\prime \prime}$, E048 $27^{\prime} 37.0^{\prime \prime}$, collection date 23 July 2014). In both cases the plants were found growing under meso-xerophytic conditions. Specimens were identified based on morphology and taking into account the main diagnostic characters.

Serratula coronata thus represents a new species record for the flora of Azerbaijan (Fig. 1, A, B). This species in Quba District was found in plant communities growing together with Campanula caucasica M.Bieb., C. latifolia L., C. rapunculoides L., C. stevenii M.Bieb., Centaurea iberica Trevir. ex Spreng., Cyanus cheiranthifolius (Willd.) Soják (Centaurea cheiranthifolia Willd.), Festuca ovina L., Erigeron orientalis Boiss., Gentiana verna L., Nonea alpestris (Steven) G.Don, N. dagestanica Kusn., Primula amoena M.Bieb., P. auriculata Lam., Thymus collinus M.Bieb., and Veronica biloba L. The plant was distrubuted in small groups. A large population of the species was found in Nakhchivan growing in assosiation with Rumex alpinus L., Polygonum cognatum Meisn., Astragalus karjaginii (Boriss.) Boriss., and Pentanema britannicum (L.) D.Gut.Larr. et al. (Inula britannica L.). The plants mainly occur in forests, forest edges, on mountain slopes, and in salty and mountain meadows.

\section{Conclusions}

Asteraceae/Compositae has been studied in Azerbaijan mainly during the 1950s-1960s and, based on collected information and herbarium data, the eighth volume of the Flora of Azerbaijan has been compiled (Flora Azerbaidzhana, 1961). This represents the main source for identification and analyzing the species of the family in the flora of Azerbaijan. As mentioned above, seven species of Serratula sensu lato recorded in the Flora of Azerbaijan (1961) and eight species in the Conspectus florae Caucasi (2012). Most of them were recently transferred to the segregate genus Klasea. Currently only two species known from Azerbaijan, S. erucifolia and $S$. coronata, are still considered as belonging to the genus Serratula sensu stricto.

As well known, over the last 40 years large-scale changes were introduced in Asteraceae systematics; in particular, tribal limits have been significantly reshaped (Funk et al., 2009). Considering taxonomic and nomenclatural changed proposed and accepted for Asteraceae, there is the urgent need to analyze the family in Azerbaijan at the level of tribes and genera. The number and list of species recorded in the flora of the country should be also further updated and specified in the future.

\section{Acknowledgments}

We are grateful to Sergei L. Mosyakin (M.G. Kholodny Institute of Botany, NAS of Ukraine) for his valuable comments on the manuscript.

\section{REFERENCES}

Agadjanov S.D. Serratula. 1961. In: Flora of Azerbaijan, vol. 8. Ed. I.I. Karyagin. Baku: Academy of Sciences of Azerbaijan SSR, pp. 423-428. [Агаджанов С.Д. 1961. Serratula. В кн.: Флора Азербайджана, т. 8. Ред. И.И. Карягин. Баку: Изд-во АН Азерб. ССР, с. 423-428].

Askerova R.K. 1970. To the palynological characteristics of the tribe Cichorieae fam. Compositae. Botanical Journal, 55(5): 660-668. [Аскерова Р.К. 1970. К палинологической характеристике трибы Cichorieae сем. Сотровіtае. Ботанический журнал, 55(5): 660-668].

Conspectus florae Caucasi, vol. 3(1). Ed. A.L. Takhtajan. 2012. St. Petersburg; Moscow: KMK Scientific Press, 469 pp. [Конспект Флоры Кавказа, т. 3(1). Ред. А.Л. Тахтаджян. 2012. СПб; М.: Тов-во науч. изданий KMK, 469 c.].

Dogan B., Duran A., Şeker M., Çetin Ö., Martin E. 2015. Study of phylogenetic relationship of Turkish species of Klasea (Asteraceae) based on ISSR amplification. PhytoKeys, 56: 29-40.

Flora Azerbaidzhana. 1961. Vol. 8. Ed. I.I. Karyagin. Baku: Academy of Sciences of Azerbaijan SSR, 688 pp. [Флора Азербайджана. 1961. Т. 1. Ред. И.И. Карягин. Баку: Изд-во АН Азерб. ССР, 688 с.].

Funk V.A., Susanna A., Stuessy T.F., Robinson H. 2009. Classification of Compositae. In: Systematics, evolution, and biogeography of Compositae. Eds V.A. Funk, A. Susanna., T.F. Stuessy, R.J. Bayer. Vienna: International Association for Plant Taxonomy (IAPT), pp. 171-192.

Gabreliyan E.S. 2012. Serratula. In: Conspectus florae Caucasi, vol. 3(1). Ed. A.L. Takhtajan. St. Petersburg; Moscow: KMK Scientific Press, pp. 280-281. [Serratula. In: Конспект Флоры Кавказа, т. 3(1). 2012. Ред. А.Л. Тахтаджян. СПб; Москва: Тов-во науч. изданий KMK, c. 280-281].

Garcia-Jacas N., Susanna A., Garnatje T., Vilatersana R. 2001. Generic delimitation and phylogeny of the subtribe Centaureinae (Asteraceae): A combined nuclear and chloroplast DNA analysis. Annals of Botany, 87: 503-515.

Martins L. 2006. Systematics and biogeography of Klasea (Asteraceae - Cardueae) and a synopsis of the genus. Botanical Journal of the Linnean Society, 152: 435-464.

Martins L., Hellwig F.H. 2005. Systematic position of the genera Serratula and Klasea within Centaureinae (Cardueae, Asteraceae) inferred from ETS and ITS sequence data and new combinations in Klasea. Taxon, 54(3): 632-638. 
Mustafayeva S.C. 2013. Asteraceae Bercht. et J. Presl fəsiləsinin öyrənilməsinə dair. AMEA-nın Xəbərlar, Biologiya və Tibb Elmlori, 68(1): 17-23. [Mustafayeva S.C. 2013. Study on Asteraceae Bercht. et J. Presl family. Proceedings of ANAS, Biology and Medical Sciences, 68(1): 17-23].

Mustafayeva S.J., Aghayeva S.O., Bakhshaliyeva K.F., Novruzov E.N. 2017. Investigation of component composition of essential oils of Pyrethrum parthenifolium Willd. and Senecio vulgaris L. Proceedings of the Institute of Botany, ANAS, 37: 89-95.

Ranjbar M., Negaresh K., Karamian R. 2015. A synopsis of Klasea sect. Schumeria (Asteraceae, Cardueae) in Iran. Novon, 24(2): 186-198.

Wagenitz G. 1959. Pollen Morphologie und Systematik in der Gattung Centaurea L. s. 1. Flora, 14: 213-279.

Wagenitz G. 1975. Centaurea. In: Flora of Turkey and the East Aegean Islands, vol. 5. Ed. P.H. Davis. Edinburgh: Edinburgh Univ. Press, pp. 465-585.
Wagenitz G., Hellwig F.H. 1996. Evolution of characters and pahylogeny of the Centaureinae. In: Compositae: Systematics. Proceedings of the International Compositae Conference. Eds D.J.N.Hind, H.G.Beentje. Kew: Royal Botanic Gardens, pp. 492-510.

Huseynova A.Yu., Qarakhani P.Kh., Nabieva P.N. 2013. To nomenclature and systematics of some species of the genus Centaurea L. (Asteraceae Dumort.). Bulletin of the Moscow State Regional University. Natural Sciences Series, 3: 19-22. [Гусейнова А.Ю., Гарахани П.Х., Набиева П.Н. 2013. К номенклатуре и систематике некоторых видов рода Centaurea L. (Asteraceae Dumort.). Вестник Московского государственного областного университета. Серия Естественные науки, 3: 19-22].

Huseynova A.Yu., Qarakhani P.Kh., Mekhtiyeva N.P. 2014. New species of the genus Centaurea (Asteraceae). Botanical Journal, 99(3): 350-352 [Гусейнова А.Ю., Гарахани П.Х., Мехтиева Н.П. 2014. Новый вид рода Centaurea (Asteraceae) из Азербайджана. Ботанический журнал, 99 (3): 350-352].

Recommended for publication by

Submitted 20.08.2018 


\title{
Вплив мікроелементів на вміст цитокінінів у міцеліальній біомасі лікарського гриба Trametes versicolor (Polyporaceae, Basidiomycota)
}

\author{
Інститут ботаніки ім. М.Г. Холодного НАН України \\ вул. Терещенківська 2, Київ 01004, Україна \\ galeb.almaali@gmail.com
}

Галеб А. АЛЬ-МААЛІ, Ніна П. ВЕДЕНИЧОВА, Ніна А. БІСЬКО, Ірина В. КОСАКІВСЬКА

Al-Maali G.A., Vedenicheva N.P., Bisko N.A., Kosakivska I.V. 2019. Effect of microelements on cytokinins content in mycelial biomass of medicinal mushroom Trametes versicolor (Polyporaceae, Basidiomycota). Ukranian Botanical Journal, 76(1): 71-78.

M.G. Kholodny Institute of Botany, National Academy of Sciences of Ukraine

2 Tereschenkivska Str., Kyiv 01004, Ukraine

Abstract. The study results of the effects of Zinc, Manganese and Copper sulfates and citrates on cytokinins content in mycelial biomass of the valuable medicinal mushroom Trametes versicolor, strain 353 from the IBK Mushroom Culture Collection of the M.G. Kholodny Institute of Botany, in culture are presented. Cytokinins were measured using high performance liquid chromatography on an Agilent 1200 LC chromatograph with a G 1315 B diode matrix detector. The addition of salts of these metals was shown to accelerate the mycelium growth. The most effective was Copper citrate, its introduction to the nutrient medium caused the biomass growth increase by almost $80 \%$. In general, citrates affected the growth of T. versicolor 353 more effectively than sulfates. Metal compounds stimulated formation of active forms of hormones (trans-zeatin and zeatin riboside) and reduced the content of inactive forms ( $c$ is-zeatin and zeatin-O-glucoside). The most significant effect on cytokinins metabolism was produced by Zinc salts, under its effect the levels of trans-zeatin and zeatin riboside increased eightfold. Sulfates of the metals influenced synthesis of zeatin riboside more effectively than citrates. All studied salts reduced the level of $c i s$-zeatin at least twice. Minor quantities of zeatin-O-glucoside detected in the control were not discovered in experiments with metals. Although the effect of the studied microelements on acceleration of the growth of mycelial biomass was generally accompanied by an increase in the content of active forms of cytokinins, quantitative dependencies between these two indices were not recorded.

Keywords: Copper, cytokinins, Manganese, microelements, Trametes versicolor, Zinc

Аль-Маалі Г.А., Веденичова Н.П., Бісько Н.А., Косаківська І.В. 2019. Вплив мікроелементів на вміст цитокінінів у міцеліальній біомасі лікарського гриба Trametes versicolor (Polyporaceae, Basidiomycota). Український ботанічний жсурнал, 76(1): 71-78.

Реферат. Наведено результати дослідження впливу сульфатів і цитратів Цинку, Мангану й Купруму на вміст цитокінінів у міцеліальній біомасі цінного лікарського гриба Trametes versicolor, штам 353, з Колекції культур шапинкових грибів (IBK) Інституту ботаніки ім. М.Г. Холодного НАН України, що вирощувався в культурі. Цитокініни визначали методом високоефективної рідинної хроматографії на хроматографі Agilent 1200 LC з діодно-матричним детектором G 1315 В. Виявлено, що додавання солей зазначених металів прискорювало ріст міцелію. Найбільш ефективним був цитрат Купруму, за умов внесення якого у живильне середовище приріст біомаси зростав майже на $80 \%$. Цитрати загалом ефективніше впливали на ріст $T$. versicolor 353 , ніж сульфати. Сполуки металів стимулювали утворення активних форм гормонів (транс-зеатину й зеатинрибозиду) та зменшували вміст неактивних форм (цис-зеатину й зеатин-O-глюкозиду). Найбільш вагомо впливали на метаболізм цитокінінів солі Цинку, за дії яких рівні трансзеатину й зеатинрибозиду зростали у 8 разів. Сульфати металів ефективніше діяли на синтез зеатинрибозиду, ніж цитрати. Усі досліджені солі пригнічували рівень цис-зеатину щонайменше удвічі. Незначні концентрації зеатин-Oглюкозиду, виявлені в контролі, в дослідах з металами не були знайдені. Хоча вплив досліджених мікроелементів на прискорення росту міцеліальної біомаси в цілому супроводжувався зростанням вмісту активних форм цитокінінів, кількісних залежностей між цими двома показниками не зафіксовано.

Ключові слова: Купрум, Манган, мікроелементи, Цинк, цитокініни, Trametes versicolor

\section{Вступ}

Значну роль у фізіології живлення грибів відіграють іони есенціальних мікроелементів. Відомо, що ( Г Г.А. АЛЬ-МААЛІ, Н.П. ВЕДЕНИЧОВА, Н.А. БІСЬКО, I.B. КОСАКIBCЬKA, 2019

Український ботанічний журнал, 2019, 76(1) додавання до живильного середовища або субстрату іонів металів за оптимальних концентрацій позитивно впливає на ріст міцелію та плодоношення макроміцетів (Malinowska et al., 2009; АльМаалі, 2015; Bidegain et al., 2015; Krakowska et al., 
2016). Найважливішими мікроелементами для повноцінного функціонування еукаріотичної клітини, у т. ч. грибної, є Цинк, Купрум та Манган (Banci, Bertini, 2013). Цинк має фундаментальне значення для процесів життєдіяльності, оскільки входить до складу каталітичних і структурних центрів великого масиву білків та $є$ єдиним елементом, який входить до складу ферментів усіх класів (Broadley et al., 2007). Майже 25\% Цинкзв'язаних білків пов'язано 3 транскрипційною регуляцією (Staats et al., 2015). Більшість окисновідновних реакцій у клітині відбувається за участі ферментів, що містять іони Купруму чи Мангану в координаційному центрі (Kaim et al., 2013). Манган як кофактор входить до складу ферментів, які каталізують гідролітичні й окисновідновні реакції (Law et al., 1998). Серед цих ферментів основну роль відіграють Манганзалежна супероксиддисмутаза, різні каталази та пероксидази (Kaim et al., 2013). Купрум є складовою ключових ферментів, необхідних для повноцінного функціонування будь-якої еукаріотичної клітини, насамперед цитохром с-оксидази, супероксиддисмутази й чисельних Купрумвмісних оксидаз (Banci, Bertini, 2013). Незважаючи на безперечну важливість мікроелементів, механізми їхньої регуляції у процесах росту й розвитку грибних організмів залишаються малодослідженими.

Гриби продукують фітогормони, зокрема цитокініни (Chanclud, Morel, 2016), функціональне значення яких остаточно не з'ясовано. Показано, що за допомогою гормонів цитокінінової природи фітопатогенні гриби маніпулюють ростом рослини-хазяїна (Grant, Jones, 2009). Екзогенні цитокініни здатні впливати на розвиток мікро- та макроміцетів. Наприклад, кінетин прискорював ріст міцелію Rhizopus oryzae Went \& Prins. Geerl. (Chatterjee et al., 2008) i Mucor indicus Lendn. (Safaei et al., 2015), позитивно впливав на розміри шапинки й довжину ніжки Pleurotus ostreatus (Jacq.) Р. Kumm. (Ramachela et al., 2016), збільшував біомасу й вміст білка у Pleurotus sajor-caju (Fr.) Singer (= Lentinus sajor-caju (Fr.) Fr.) (Mukhopadhyay et al., 2005) i Agaricus campestris L. (Guha, Banerjee, 1974). Рівні ендогенних цитокінінів змінювались відповідно до швидкості росту міцелію Hericium coralloides (Scop.) Pers. i Fomitopsis officinalis (Vill.: Fr.) Kotl. \& Pouzar (Vedenicheva et al., 2018a), що свідчить про їхню потенційну регуляторну функцію.

Відомо, що у рослин інформація про доступність поживних елементів, а також контроль за їхнім засвоюванням відбувається за допомогою цитокінінів (Kieber, Schaller, 2014). Найкраще досліджено роль цитокінінів в асиміляції азоту (Kiba et al., 2011). Встановлено участь цих гормонів у поглинанні сполук Феруму (Séguéla et al., 2008), Натрію (Mason et al., 2010), Калію (Nam et al., 2012). У пагонах цитокінін-дефіцитних рослин ячменю змінювався рівень вмісту Мангану й Цинку (Ramireddy et al., 2018). Відомості щодо зв'язку між засвоюванням іонів металів та цитокінінами у грибів практично відсутні. Для з'ясування цього питання ми досліджували вплив мікроелементів у вигляді органічних та неорганічних солей на синтез цитокінінів у гриба Trametes versicolor (L.) Lloyd. Метою даної роботи були оптимізація умов культивування цінного лікарського базидіоміцета та зрозуміння функцій фітогормонів цитокінінової природи у грибів.

\section{Матеріали та методи}

У дослідженні використовували T. versicolor, штам 353, з Колекції культур шапинкових грибів (IBK) Інституту ботаніки ім. М.Г. Холодного НАН України (Bisko et al., 2016).

В усіх дослідах контролем слугувало живильне середовище (ГПД) такого складу, г/дм³: глюкоза 25 ; пептон - 3; дріжджовий екстракт - 3; $\mathrm{K}_{2} \mathrm{HPO}_{4}$ $1 ; \mathrm{KH}_{2} \mathrm{PO}_{4}-1 ; \mathrm{MgSO}_{4} \cdot 7 \mathrm{H}_{2} \mathrm{O}-0,25$; дистильована вода -1 дм ${ }^{3}$; $\mathrm{pH} 6,5$.

У дослідних варіантах до живильного середовища ГПД додавали попередньо встановлені оптимальні для накопичення біомаси концентрації іонів Цинку (1 мг/дм³ $)$, Мангану (1 мг/дм³) та Купруму (4 мг/дм $\left.{ }^{3}\right)$. Джерелом мікроелементів слугували сульфати та цитрати зазначених металів. Всі цитрати металів були отримані методом аквананотехнологіï (Kosinov, Kaplunenko, 2009) в Українському державному науково-дослідному Інституті нанобіотехнологій та ресурсозбереження при Державному агентстві резерву України.

Інокуляцію міцелієм проводили поетапно:

1) інокулюм отримували при культивуванні міцелію штаму 353 упродовж 7 діб за температури $26 \pm 1{ }^{\circ} \mathrm{C}$ на ГПД-середовищі з додаванням 20 г/дм ${ }^{3}$ агар-агара;

2) інокуляцію рідкого живильного середовища (ГПД) проводили гомогенізованим міцелієм, отриманим на першому етапі з розрахунку $10 \%$ об'єму живильного середовища. Культивували на лабораторних качалках упродовж 4 діб (120 об/хв) за 
температури $26 \pm 1{ }^{\circ} \mathrm{C}$ у колбах Ерленмеєра об`ємом $250 \mathrm{~cm}^{3}$, що містили $50 \mathrm{~cm}^{3}$ живильного середовища;

3) отриману на другому етапі культуру використовували для інокуляції рідкого ГПДсередовища в серії дослідів 3 вивчення впливу мікроелементів на синтез цитокінінів. Міцелій, отриманий на другому етапі, додавали з розрахунку $10 \%$ загального об'єму живильного середовища. Міцелій вирощували 9 діб на лабораторних качалках за тих самих умов.

Для аналізу цитокінінів наважку біомаси 10 г гомогенізували в електричному гомогенізаторі (Mechanika Precyzyjna, Польща), тричі екстрагували 80\%-ним розчином етанолу та випарювали до водної фази, яку піддавали проморожуванню при $-20{ }^{\circ} \mathrm{C} \quad 3$ подальшим центрифугуванням на центрифузі K 24 (Janetzky, Німеччина) при 15000 об/хв. Отриманий супернатант фракціонували з водонасиченим н-бутанолом (співідношення 1 : 1, за об'ємом), який потім випарювали. Очищення цитокінінової фракції проводили 3 використанням іонообмінної хроматографії на колонці $20 \times 2$ см Bio-Rad (США) зі смолою Dowex 50Wx8 (Serva, Німеччина) в $\mathrm{H}^{+}$-формі (елюція 0,1 М аміаком), а потім - за допомогою тонкошарової хроматографії на пластинах Silicagel $60 \mathrm{~F}_{254}$ (Merk, Німеччина) у суміші розчинників ізопропанол : аміак : вода (10:1 : 1, за об'ємом). Більш детально умови виділення та очищення цитокінінів з міцеліальної біомаси грибів описано раніше (Vedenicheva et al., 2016).

Остаточний якісний та кількісний аналіз вмісту цитокінінів проводили методом високоефективної рідинної хроматографії на хроматографі Agilent 1200 LC з діодно-матричним детектором G 1315 B (США) 3 використанням колонки Eclipse XDBC18 2,1 $\times 150$ мм, розмір часточок становив $5 \mu$ м. Елюцію виконували в системі розчинників метанол : вода (37 : 63) (за об'ємом). Аналіз і обробку хроматограм проводили з використанням програмного забезпечення Chem Station, версія В.03.01 у режимі online. Маркерами в роботі слугували стандартні розчини зеатину трансзеатину, цис-зеатину, зеатинрибозиду, ізопентеніладенозину, ізопентеніладеніну та зеатин-Oглюкозиду (Sigma, США).

Досліди проводилися в 3-разових біологічних та 5-7-разових аналітичних повторах. Результати статистично оброблені $(P \leq 0.05)$ за допомогою програми Microsoft Excel 2003. Риски на діаграмах
Таблиця 1. Вплив солей металів на приріст біомаси Trametes versicolor 353

Table 1 . The influence of metal salts on the growth of biomass of Trametes versicolor 353

\begin{tabular}{|l|c|c|}
\hline \multicolumn{1}{|c|}{ Варіант досліду } & Біомаса, г/дм ${ }^{3}$ & Приріст біомаси, $\%$ \\
\hline контроль & $4,8 \pm 0,2$ & 0 \\
\hline цитрат Цинку & $6,5 \pm 0,1^{*}$ & $36,7^{*}$ \\
\hline сульфат Цинку & $5,8 \pm 0,2^{*}$ & $22,0^{*}$ \\
\hline цитрат Мангану & $6,2 \pm 0,2^{*}$ & $28,9^{*}$ \\
\hline сульфат Мангану & $5,1 \pm 0,3$ & 5,9 \\
\hline цитрат Купруму & $8,9 \pm 0,2^{*}$ & $79,9^{*}$ \\
\hline сульфат Купруму & $7,1 \pm 0,1^{*}$ & $48,9^{*}$ \\
\hline
\end{tabular}

*достовірна різниця з контрольним дослідом $P<0,05$.

відповідають достовірчим інтервалам (рівень вірогідності 0,95).

\section{Результати та обговорення}

Виявлено, що додавання сполук Цинку, Мангану та Купруму значною мірою стимулює приріст міцеліальної біомаси T. versicolor 353 порівняно із контролем (табл. 1). Ефективнішими були цитрати металів, ніж відповідні за катіоном сульфати. Як органічні, так і неорганічні солі Купруму сприяли максимальному прискоренню росту міцелію, тоді як іони Мангану у складі аналогічних солей мали найменшу дію.

За результатами аналізу цитокінінів міцеліальної біомаси $T$. versicolor 353 у контрольних умовах було визначено наступні гормони: транс-зеатин, цис-зеатин, зеатинрибозид і зеатин- $O$-глюкозид. Ізопентеніладенозин й ізопентеніладенін не були виявлені (рис. 1-3).

У ході експерименту з культивування міцелію T. versicolor 353 на середовищі 3 цитратами або сульфатами металів встановлено суттєві кількісні та якісні зміни в складі цитокінінів. Так, у міцелію, культивованому на середовищах із додаванням сполук металів, в усіх варіантах не було знайдено зеатин- $O$-глюкозиду на відміну від контрольного досліду (рис. 1-3). На середовищі зі сульфатом Цинку вміст цис-зеатину в біомасі $T$. versicolor 353 зменшувався порівняно 3 контролем майже вдвічі, а на середовищі з цитратом Цинку даного цитокініну взагалі не було виявлено (рис. 1). Водночас, іони Цинку в обох досліджених формах значною мірою стимулювали синтез транс-зеатину та зеатинрибозиду. Додавання до живильного середовища сульфату Цинку сприяло зростанню вмісту транс-зеатину в міцеліальній біомасі 


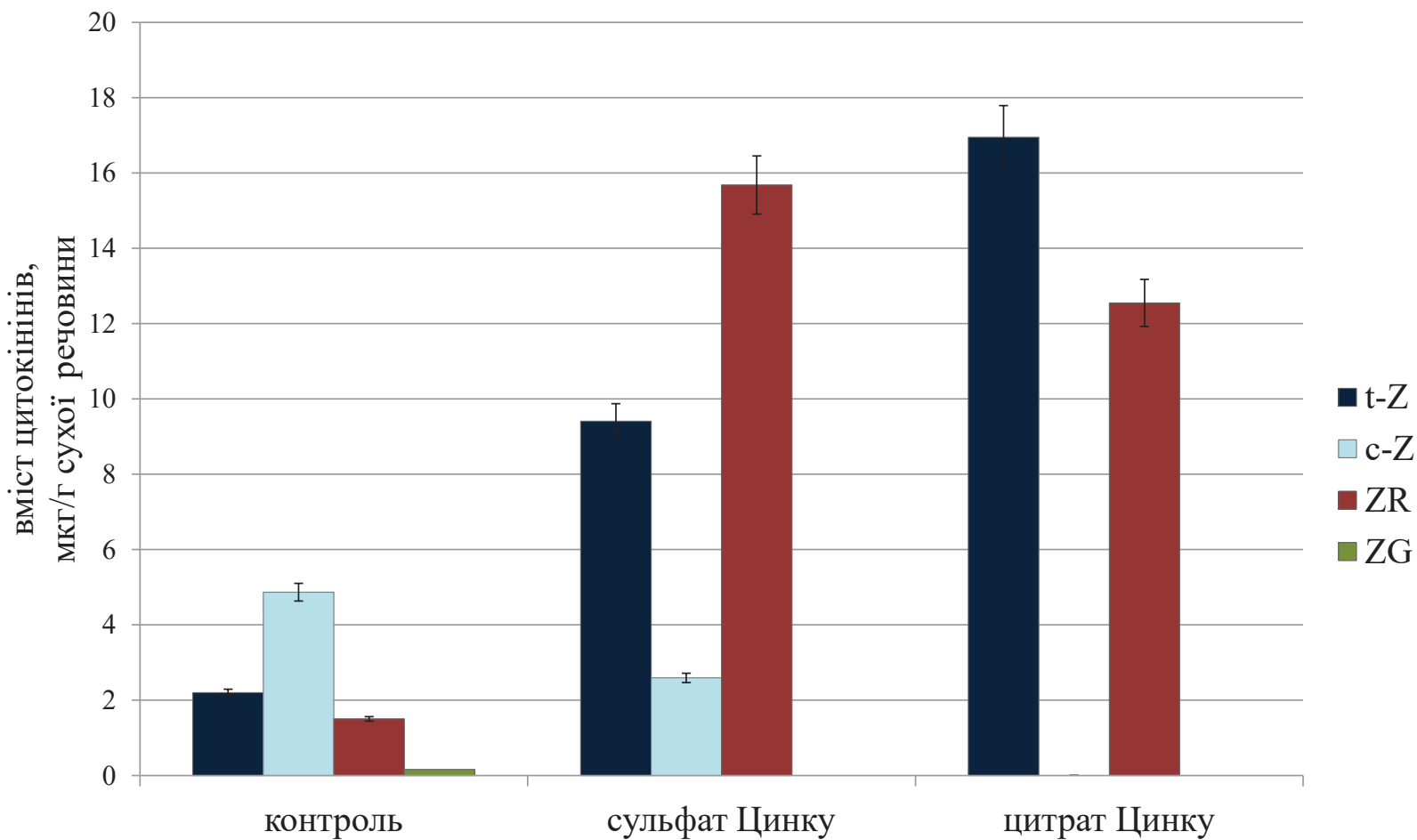

варіант досліду

Рис. 1. Вміст цитокінінів у міцеліальній біомасі штаму Trametes versicolor 353 за умов додавання солей Цинку до глюкозо-пептон-дріжджового середовища (ГПД).

Тут і на рис. 2, 3: $\mathrm{t}-\mathrm{Z}$ - транс-зеатин, c-Z - иис-зеатин, ZR - зеатинрибозид, ZG - зеатин- $O$-глюкозид

Fig. 1. Cytokinins content in mycelial biomass of Trametes versicolor 353 after addition of Zinc salts in GPD-medium.

Here and thereafter: t-Z - trans-zeatin, c-Z - cis-zeatin, ZR - zeatin riboside, ZG - zeatin- $O$-glucoside

T. versicolor 353 у 4,3 раза, а зеатинрибозиду - в 10,4 раза порівняно з контролем. За наявності цитрату Цинку в середовищі було зафіксовано 8-кратне збільшення рівнів транс-зеатину й зеатинрибозиду. У цілому, за присутності сульфату або цитрату Цинку загальна концентрація цитокінінів у біомасі T. versicolor 353 збільшувалася втричі порівняно 3 контролем (рис. 1).

Внесення в живильне середовище сульфату або цитрату Мангану стимулювало синтез зеатинрибозиду та пригнічувало утворення цисзеатину в міцеліальній біомасі $T$. versicolor 353 (рис. 1). Так, при додаванні сульфату Мангану вміст цис-зеатину в міцелію $T$. versicolor 353 зменшувався в 2,8 раза, а вміст зеатинрибозиду зростав у 8 разів. При заміні в середовищі сульфату Мангану на відповідний цитрат, концентрація цис-зеатину в біомасі $T$. versicolor 353 зменшувалася в 2,2 раза, а концентрація зеатинрибозиду зростала в 4,3 раза. При цьому цитрат Мангану повністю пригнічував утворення транс-зеатину, тоді як сульфат Мангану підвищував його вміст у міцелію на 68,64\% відносно до контролю (рис. 1). Зазначимо, що у випадку з цитратом Мангану загальний вміст цитокінінів порівняно з контролем не змінювався. За наявності в середовищі іонів Мангану в сульфатній формі загальна концентрація цитокінінів у міцелію T. versicolor 353 зростала вдвічі.

Іони Купруму, додані до живильного середовища, стимулювали синтез транс-зеатину та зеатин-рибозиду (рис. 3). Вплив сульфату Купруму на ці цитокініни виявився більш виразним, ніж відповідного цитрату. Так, на середовищі 3 сульфатом Купруму вміст транс-зеатину в міцелію T. versicolor 353 збільшувався в 2,7 раза, а зеатинрибозиду - в 9 разів відносно до контролю. Додавання цитрату Купруму призводило до зростання рівня зеатинрибозиду лише в 4,7 раза, а транс-зеатину - в 1,8 раза. Як цитрат, так $\mathrm{i}$ сульфат Купруму пригнічували синтез цис-зеатину.

Ukrainian Botanical Journal, 2019, 76(1) 


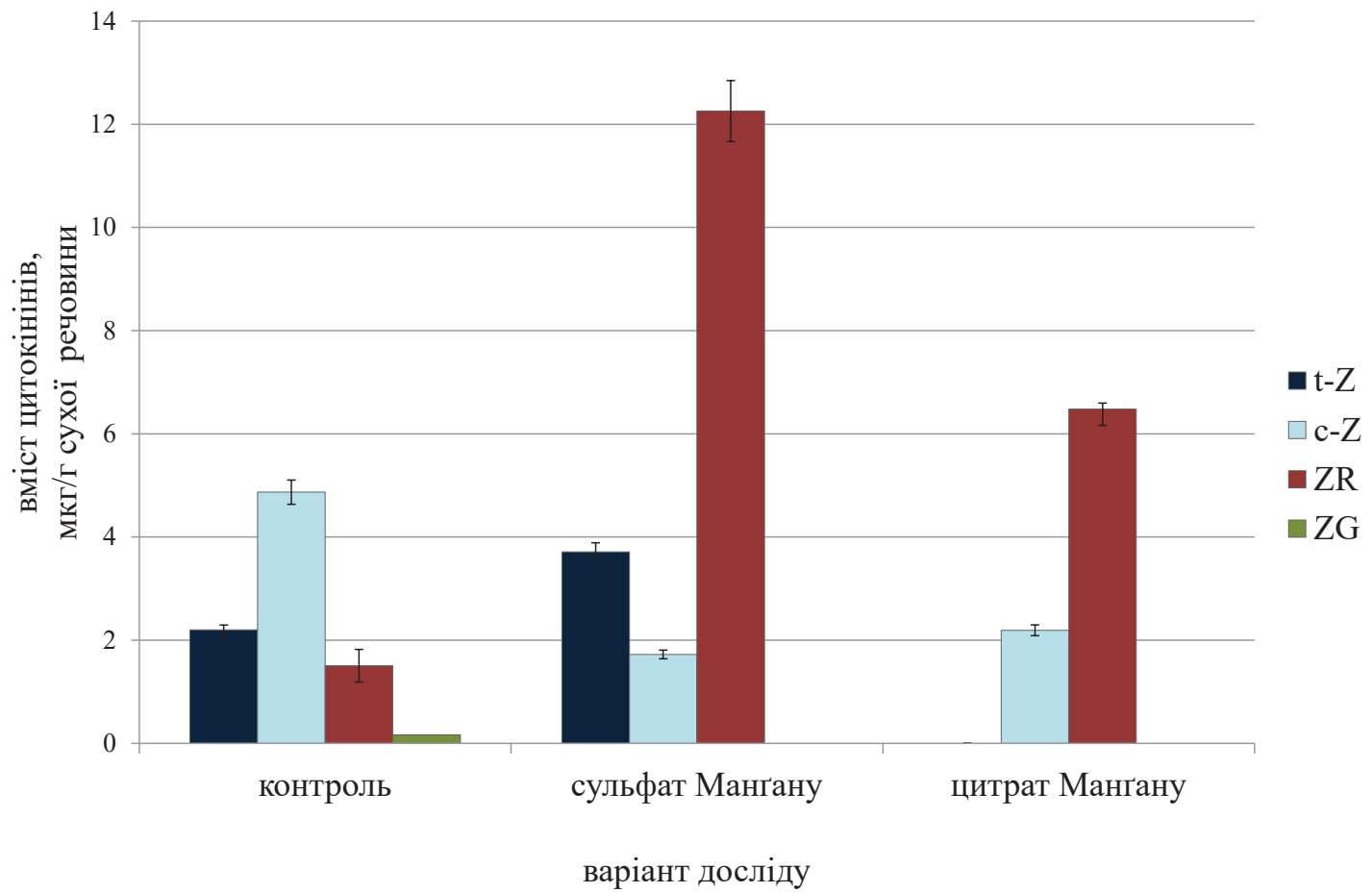

Рис. 2. Вміст цитокінінів у міцеліальній біомасі штаму Trametes versicolor 353 за умов додавання солей Мангану в ГПДсередовище

Fig. 2. Cytokinins content in mycelial biomass of Trametes versicolor 353 after addition of Manganese salts in GPD-medium

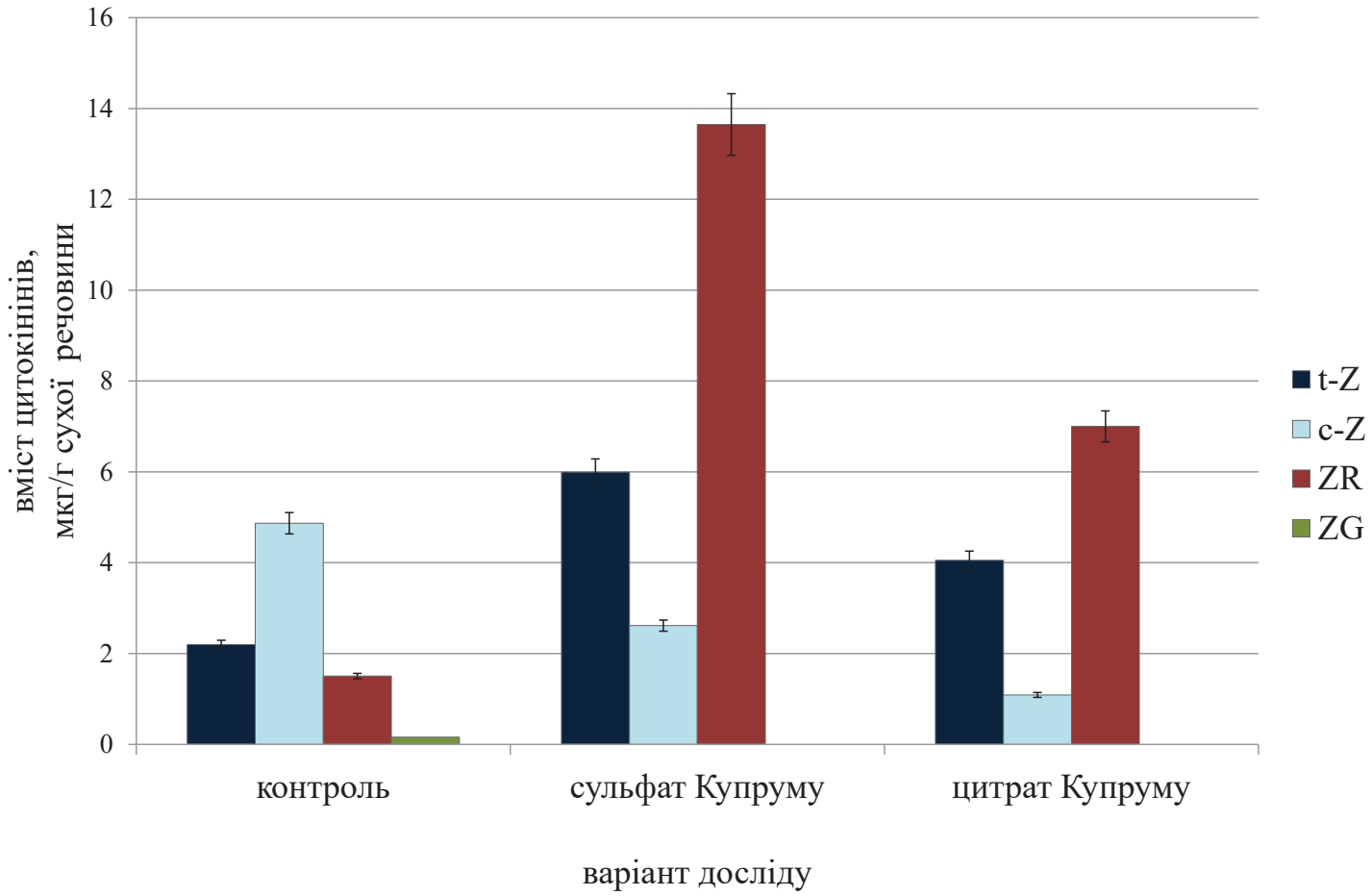

Рис. 3. Вміст цитокінінів у міцеліальній біомасі Trametes versicolor 353 за умов додавання солей Купруму в ГПДсередовище

Fig. 3. Cytokinins content in mycelial biomass of Trametes versicolor 353 after addition of Copper salts in GPD-medium 
Кількість цис-зеатину в міцелію T. versicolor 353, культивованому на середовищі зі сульфатом Купруму, зменшувалася в 1,8 раза, а на середовищі з цитратом - у 4,5 раза. Загальний вміст цитокінінів у міцелію $T$. versicolor 353 зростав за дії цитрату Купруму на $41 \%$, а за дії сульфату - на $158 \%$ (рис. 3 ).

Наведені результати свідчать, що наявність іонів Цинку, Мангану й Купруму в живильному середовищі для культивування впливає на швидкість росту міцеліальної біомаси $T$. versicolor 353. Позитивний вплив цих мікроелементів на швидкість росту міцелію та утворення склероціїв спостерігалося також при вирощуванні зморшків (Morchella spp.) у культурі (Liu et al., 2017). У наших дослідженнях показано, що ефективність дії іонів металів залежить від того, у якій формі вони вносилися у середовище. Зокрема, цитрати в усіх варіантах дослідів прискорювали ріст міцелію сильніше, ніж сульфати. Раніше було виявлено системний характер змін в жирнокислотному, амінокислотному та моносахаридному складі біомаси T. versicolor 353 під впливом цитратів Цинку, Мангану та Купруму порівняно з відповідними сульфатами (Al-Maali, 2016). Ймовірно, органічні сполуки, як більш природні, краще засвоюються грибними клітинами, що необхідно враховувати при оптимізації умов культивування.

У наших експериментах уперше встановлено вплив мікроелементів на баланс ендогенних цитокінінів у міцеліальній біомасі T. versicolor 353 . Всі досліджені іони металів суттєво пригнічували синтез цис-зеатину і стимулювали утворення трансзеатину або зеатинрибозиду. Крім того, у дослідних зразках не було виявлено зеатин- $O$-глюкозиду, який в незначній кількості був присутній у контролі. Як відомо, в біотестах транс-зеатин і зеатинрибозид $€$ найбільш активними гормонами цитокінінового ряду, вони зазвичай домінують у рослинних тканинах і превалюють на стадіях активного росту (Vedenicheva, Kosakivska, 2017). Транс-зеатин виявляє найбільшу спорідненість до рецепторів цитокінінів (Romanov, 2009). Завдяки цим особливостям зеатинові гормони розглядаються як діючі форми цитокінінів, що безпосередньо беруть участь у регуляції розвитку рослин. У грибів транс-зеатин і зеатинрибозид було виявлено як у плодових тілах (Morrison et al., 2015), так і в міцелію макроміцетів (Vedenicheva et al., 2018b). Динаміка цих цитокінінів у міцеліальній біомасі $H$. coralloides і $F$. officinalis опосередковано вказує на вірогідність їхньої участі в регуляції росту грибів (Vedenicheva et al., 2018a). Таку можливість підтверджують i наші досліди щодо зростання вмісту цих форм цитокінінів, яке відбувалося на фоні стимуляції ростових процесів сполуками Цинку, Мангану та Купруму. Вплив дії металів на ріст гриба Amanita muscaria і цитокінінів було показано раніше: гальмування розвитку міцелію після обробки Алюмінієм корелювало зі зниженням загальної кількості цитокінінів (Kovač, Žel, 1995).

Одночасно зі зростанням вмісту активних цитокінінів нами виявлено зменшення рівнів неактивних форм - цис-зеатину та зеатин- $O$-глюкозиду. Біологічна активність даних цитокінінів у біотестах значно менша, ніж транс-зеатину та зеатинрибозиду, а кількісно вони переважають у тканинах рослин з обмеженим ростом - насінні та старіючих листках (Mok, Mok, 2001; Gajdosová et al., 2011). Разом із цим, вони здатні легко трансформуватися в активні форми цитокінінів за допомогою ферментів иис/транс-ізомераза (Yonekura-Sakakibara et al., 2004) та $\beta$-глюкозидаза (Mok, Mok, 2001) відповідно. Існує думка, що в мохів і грибів цис-форми цитокінінів слугують для підтримки гормонального гомеостазу (Záveská Drábková et al., 2015). Цілком вірогідно, що у дослідженого нами гриба T. versicolor 353 зростання вмісту транс-зеатину i зеатинрибозиду, яке спостерігається за дії мікроелементів, відбувається не шляхом прямого біосинтезу, а за рахунок перетворень цис-зеатину та зеатин- $O$-глюкозиду, а отже метаболізм цитокінінів має певні риси схожості з рослинами. Крім того, цис-зеатин може утворюватися в процесі розпаду $m$ PHК (Gajdosová et al., 2011), а тому не виключено, що досліджувані метали впливають і на цей процес.

Зазначимо, шо хоча за дії досліджених сполук металів прискорення росту міцеліальної біомаси супроводжувалося зростанням вмісту активних форм цитокінінів, кількісних залежностей між цими двома показниками не було виявлено. Так, найбільшу стимуляцію приросту міцелію спричиняв цитрат Купруму, тоді як зростання рівнів трансзеатину й зеатинрибозиду було максимальним за дії цитрату Цинку. Цитрати загалом ефективніше впливали на ріст $T$. versicolor 353, ніж сульфати, проте ми не спостерігали їхнього впливу на концентрацію цитокінінів. Наприклад, сульфат Купруму сильніше активував утворення активних форм цитокінінів, ніж цитрат, хоча його дія на 
ріст міцелію була незначною. Це свідчить про опосередкованість дії іонів металів на біосинтез і метаболізм цитокінінів. Слід враховувати також вплив аніонної складової досліджуваних солей. У рослин, зокрема в арабідопсису (Arabidopsis thaliana (L.) Неynh.), продемонстровано, що цитокініни беруть участь у регуляції асиміляції Сульфуру через активацію ключового ферменту метаболізму сірчаних сполук (Ohkama et al., 2002). Отже, можна припустити, що в грибних тканинах сульфатний залишок може діяти на метаболізм цитокінінів за принципом зворотного зв'язку. Не виключено, що поєднання сульфатного чи цитратного залишку 3 кожним із іонів металів має свою специфічну дію та регулюється у специфічний спосіб.

Таким чином, отримані нами результати показали, що сполуки ессенціальних металів суттєво впливають на метаболізм і синтез цитокінінів у міцеліальній біомасі макроміцета T. versicolor 353 , проте зробити висновок щодо участі цих гормонів у регуляції засвоювання мікроелементів та ростових процесах гриба поки що неможливо.

\section{Висновки}

Нами уперше досліджено вплив іонів Цинку, Мангану та Купруму на вміст ендогенних цитокінінів у міцеліальній біомасі лікарського гриба $T$. versicolor при вирощуванні in vitro. Виявлено зростання рівнів активних форм гормонів (транс-зеатину і зеатинрибозиду) та зменшення концентрацій неактивних форм (цис-зеатину i зеатин- $O$-глюкозиду) за дії мікроелементів на фоні прискорення темпів росту міцелію. На кількісний вміст цитокінінів найбільш вагомо впливали солі Цинку. Сульфати металів ефективніше діяли на утворення зеатинрибозиду, ніж цитрати. Кореляцій між впливом мікроелементів на швидкість росту міцеліальної біомаси $T$. versicolor 353 і кількісним вмістом цитокінінів не встановлено.

\section{СПИСОК ПОСИЛАНЬ}

Al-Maali G.A. 2015. Ukrainian Botanical Journal, 72(4): 393-397. [Аль-Маалі Г.А. 2015. Вплив цитратів металів, отриманих методом аквананотехнології, на ріст штамів лікарських макроміцетів Ganoderma lucidum 1900 і Trametes versicolor 353. Український ботанічний журнал, 72(4): 393-397]. https://doi.org/10.15407/ ukrbotj72.04.393

Al-Maali G.A. 2016. The effect of citrate and sulfate of different metals on the biomass composition of medicinal mushroom Trametes versicolor (L.) Lloyd. Chornomorski botanical journal, 12(1): 64-71.
Banci L., Bertini I. 2013. Metallomics and the cell. In: Metal Ions in Life Sciences 12. Ed. L. Banci. Dordrecht, The Netherlands: Springer, pp. 1-13. https://doi. org/10.1007/978-94-007-5561-1_1

Bidegain M.A., Cubitto M.A., Curvetto N.R. 2015. Optimization of the yield of lingzhi or Reishi medicinal mushroom, Ganoderma lucidum (Higher Basidiomycetes), cultivated on a sunflower seed hull substrate produced in Argentina: effect of olive oil and copper. International Journal of Medicinal Mushrooms, 17(11): 1095-1105. https://doi.org/10.1615/IntJMedMushrooms.v17.i11.100

Bisko N.A., Lomberg M.L., Mytropolska N.Yu., Mykchaylova O.B. 2016. IBK Mushroom culture collection. Kyiv: Alterpress, $120 \mathrm{pp}$.

Broadley M.R., White P.J., Hammond J.P., Zelko I., Lux A. 2007. Zinc in plants. New Phytologist, 173(4): 677-702. https://doi.org/10.1111/j.1469-8137.2007.01996.x

Chanclud E, Morel J.-B. 2016. Plant hormones: a fungal point of view. Molecular Plant Pathology, 17(8): 12891297. https://doi.org/10.1111/mpp.12393

Chatterjee S., Chatterjee B.P., Guha A.K. 2008. Enhancement of growth and chitosan production by Rhizopus oryzae in whey medium by plant growth hormones. International Journal of Biological Macromolecules, 42(2): 120-126. https://doi.org/10.106/j.ijbiomac.2007.10.006

Gajdosová S., Spičhal L., Kaminek M., Hoverová K., Novák O.,Dobrev P.I., Galuszka P., Klima P., Gaudinová A., Zizková E., Hanus J., Dancák M., Trávnicek B., Pesek B., Krupicka M., Vanková R., Strnad M., Motyka V. 2011. Distribution, biological activities, metabolism and the conceivable function of cis-zeatin-type cytokinins in plants. Journal of Experimental Botany, 62: 2827-2840. https://doi.org/10.1093/jxb/erq457/

Grant M.R., Jones J.D. 2009. Hormone (dis)harmony moulds plant health and disease. Science, 324: 750-752. https://doi.org/10.1126/science. 1173771

Guha A.K., Banerjee A.B. 1974. Effect of indole-3-acetic acid and kinetin on submerged growth of Agaricus campestris. Acta microbiologica Polonica, 6(3): 133-134.

Kaim W., Schwederski B., Klein A. 2013. Bioinorganic Chemistry: Inorganic Elements in the Chemistry of Life. An Introduction and Guide. John Wiley \& Sons, 456 pp.

Kiba T., Kudo T., Kojima M., Sakakibara H. 2011. Hormonal control of nitrogen acquisition: roles of auxin, abscisic acid, and cytokinin. Journal of Experimental Botany, 62(4): 1399-1409. https://doi.org/10.1093/jxb/erq410

Kieber J.J., Schaller G.E. 2014. Cytokinins. The Arabidopsis Book, 11: e0168. https://doi.org/10.1199/tab.0168

Kosinov M.V., Kaplunenko V.G. 2009. Sposib otrymannya karboksylativ kharchovykh kyslot $z$ vykorystannyam nanotekhnologij. Patent UA, no 39392, publ. 25.02.2009, 200 pр. [Спосіб отримання карбоксилатів харчових кислот з використанням нанотехнології: патент України № 39392, МПК: С07C 51/41, С07F 5/00, C07F 15/00, В82В 3/00 / Косінов М.В., Каплуненко В.Г. Опубл. 25.02.2009, Бюл. № 4, 2009, 200 с.].

Kovač M., Žel J. 1995. The effect of aluminum on cytokinins in the mycelia of Amanita muscaria. Journal of Plant Growth Regulation, 14: 117-120. 
Krakowska A., Reczyński W., Muszyńska B. 2016. Optimization of the liquid culture medium composition to obtain the mycelium of Agaricus bisporus rich in essential minerals. Biological Trace Element Research, 173(1): 231-240. https://doi.org/10.1007/s12011-016-0638-y

Law N., Caudle M., Pecoraro V. 1998. Manganese redox enzymes and model systems: properties, structures and reactivity. Advances in Inorganic Chemistry, 46(7): 305440. https://doi.org/10.1016/S0898-8838(08)60152-X

Liu Q., Liu H., Chen C., Wang J., Han Y., Long Z. 2017. Effects of element complexes containing Fe, Zn and Mn on artificial morel's biological characteristics and soil bacterial community structures. PLoS ONE, 12(3): e0174618. http://doi.org/10.1371/journal.pone.0174618

Malinowska E., Krzyczkowski W., Łapienis G., Herold F. 2009. Improved simultaneous production of mycelial biomass and polysaccharides by submerged culture of Hericium erinaceum: optimization using a central composite rotatable design (CCRD). Journal of Industrial Microbiology \& Biotechnology, 36(12): 1513-1527. http://doi.org/10.1007/s10295-009-0640-X

Mason M.G., Jha D., Salt D.E., Tester M., Hill K., Kiebes J.J., Schaller G.E. 2010. Type-B response regulators ARR1 and ARR12 regulate expression of AtHKT1;1 and accumulation of sodium in Arabidopsis shoots. Plant Journal, 64: 753-763. https://doi. org/10.1111/j.1365-313X.2010.04366.x

Mok D.W.S., Mok M.C. 2001. Cytokinin metabolism and action. Annual Review of Plant Physiology and Plant Molecular Biology, 52: 89-118. https://doi.org/10.1146/ annurev.arplant.52.1.89

Morrison E.N., Knowles S., Hayward A., Thorn R.G., Saville B.J., Emery R.J. 2015. Detection of phytohormones in temperate forest fungi predicts consistent $\mathrm{ab}-$ scisic acid production and a common pathway for cytokinin biosynthesis. Mycologia, 107(2): 245-257. http:// doi.org/10.3852/14-157

Mukhopadhyay R., Chatterjee S., Chatterjee B.P., Guha A.K. 2005. Enhancement of biomass production of edible mushroom Pleurotus sajor-caju grown in whey by plant growth hormones. Process Biochemistry, 40(3-4): 1241-1244. https://doi.org/10.1016/j. procbio. 2004.05 .006

Nam Y.J., Tran L.S., Kojima M., Sakakibara H., Nishiyama R. 2012. Regulatory roles of cytokinins and cytokinin signaling in response to potassium deficiency in Arabidopsis. PLoS One, 7(10): e47797. https://doi.org/10.1371/journal.pone.0047797

Ohkama N., Takei K., Sakakibara H., Hayashi H., Yoneyama T., Fujiwara T. 2002. Regulation of sulfur-responsive gene expression by exogenously applied cytokinins in Arabidopsis thaliana. Plant Cell Physiology, 43: 14931501. https://doi.org/10.1093/pcp/pcf183

Ramachela K., Sihlangu S.M., Moral M.T. 2016. Effect of various hormonal treated plant substrates on development and yield of Pleurotus ostreatus. Cogent Food \& Agriculture, 2(1): 1276510. https://doi.org/10.1080/2331 1932.2016.1276510

Ramireddy E., Hosseimi S.A., Eggert K., Gillandt S., Gnad H., Von Wirén N., Schmulling T. 2018. Root engineering in barley: increasing cytokinin degradation produces a larger root system, mineral enrichment in the shoot and improved drought tolerance. Plant Physiology, 177(3): 1078-1095. https://doi.org/10.1104/ pp.18.00199

Romanov G.A. 2009. How do cytokinins affect the cell? Russian Journal of Plant Physiology, 56(2): 268-290. https://doi.org/10.1134/SI021443709020174

Safaei Z., Karimi K., Golkar P., Zamani A. 2015. Effects of plant hormones on Mucor indicus growth and chitosan and ethanol production. International Journal of Molecular Sciences, 16(7): 16683-16694. https://doi. org/10.3390/ijms160716683

Séguéla M., Briat J.F., Vert G., Curie C. 2008. Cytokinins negatively regulate the root iron uptake machinery in Arabidopsis through a growth-dependent pathway. Plant Journal, 55: 289-300. https://doi. org/10.1111/j.1365-313X.2008.03502.X

Staats C.C., Kmetzsch L., Schrank A., Vainstein M.H. 2015. Fungal zinc metabolism and its connections to virulence. Frontiers in Cellular and Infection Microbiology, 3: 65. https://doi.org/10.3389/fcimb.2013.00065

Vedenicheva N.P., Al-Maali G.A., Mytropolska N.Yu., Mykhaylova O.B., Bisko N.A., Kosakivska I.V. 2016. Endogenous cytokinins in medicinal basidiomycetes mycelial biomass. Biotechnologia Acta, 9(1): 55-63. https:// doi.org/10.15407/biotech9.01.055

Vedenicheva N.P., Kosakivska I.V. 2017. Cytokinins as regulators of plant ontogenesis under different growth conditions. Kyiv: Nash Format, 200 pp. [Веденичова Н.П., Косаківська I.В. Цитокініни як регулятори онтогенезу рослин за різних умов зростання. Київ: Наш формат, 2017, 200 c.].

Vedenicheva N.P., Al-Maali G.A., Mykchaylova O.B., Lomberg M.M., Bisko N.A., Shcherbatiuk M.M., Kosakivska I.V. 2018a. Endogenous cytokinins dynamics in mycelial biomass basidiomycetes at different stages of cultivation. International Journal of Biochemistry \& Physiology, 3(2): 000122. https://medwinpublishers.com/ IJBP/IJBP16000122.pdf

Vedenicheva N.P., Al-Maali G.A., Bisko N.A., Shcherbatiuk M.M., Lomberg M.M., Mytropolska N.Yu., Mykchaylova O.B., Kosakivska I.V. 2018b. Comparative analysis of cytokinins in mycelial biomass of medicinal mushrooms. International Journal of Medicinal Mushrooms, 20(9): 837-847. https://doi.org/10.1615/ IntJMedMushrooms.2018027797

Yonekura-Sakakibara K., Kojima M., Yamaya T., Sakakibara H. 2004. Molecular characterization of cytokininresponsive histidine kinases in maize. Differential ligand preferences and response to cis-zeatin. Plant Physiology, 134: 1654-1651. https://doi.org/10.1104/pp.103.037176

Záveská Drábková L., Dobrev P.I., Motyka V. 2015. Phytohormone profiling across the Bryophytes. PLOS ONE, 10(5): e0125411. https://doi.org/10.1371/journal.pone. 0125411

Рекомендує до друку

Надійшла 23.01.2019

М. Сухомлин 


\section{Вшанування пам'яті Антонія Анджейовського}

Антоній Анджейовський належить до непересічних особистостей, обдарованих багатьма талантами. У наукових колах його ім'я як одного з перших дослідників природи України добре відоме ботанікам, зоологам, геологам, палеонтологам, результати його досліджень $є$ піонерними для окремих наукових напрямів. Найбільш знаний він як ботанік: підготував докторську дисертацію по одній з груп родини хрестоцвітих, опублікував відомі праці з ботаніки "Rys botaniczny..." (1823, 1830), "Flora Ukrainy..." (1869) та ін., зібрав гербарну колекцію. Частина зборів обсягом близько 10 тис. аркушів увійшла в іменну історичну колекцію В.Г. Бессера та зберігається в Інституті ботаніки ім. М.Г. Холодного НАН України (KW). Серед гербарних зборів А. Анджейовського особливо цінними є типові зразки описаних ним нових для науки таксонів рослин. Разом із колегами він є автором першої геологічної мапи Поділля, як палеонтолог, що стояв у витоків цієї науки в Україні, описав нові для науки видів викопних молюсків. Серед краєзнавців добре відомі його літературні твори і особливо "Ramoty starego Detiuka о Wołyniu" (1866). Малював, у різний час викладав малювання та біологічні дисципліни.

Життєвий та творчий шлях А. Анджейовського був складним. Його професійне становлення відбулося у Вищій Волинській гімназії, яку він закінчив. Згодом з Alma mater його пов'язала не лише трудова діяльність, але й знайомство в ній з Віллібальдом Бессером, яке визначило подальший шлях і наукові інтереси А. Анджейовського. Після "знищення" Вищої Волинської гімназії разом 3 іншими викладачами він переїхав до Києва, де працював на посаді ад'юнкта Імператорського Київського університету св. Володимира і захищав докторську дисертацію, а згодом був професором фізико-математичного ліцею князя Безбородька в Ніжині. Останні дванадцять років свого життя провів у містечку Ставище, де заклав та розбудовував приватний ботанічний сад, проводив наукові дослідження.

29 вересня 2018 р. $з$ ініціативи Ставищенського настоятеля парафії Пресвятої Трійці Римо-

( ) Л.В. ЗАВ'ЯЛОВА, О.О. СЕНЧИЛО, В.П. КОЛОМІЙЧУК, О.О. КУЧЕР, 2019

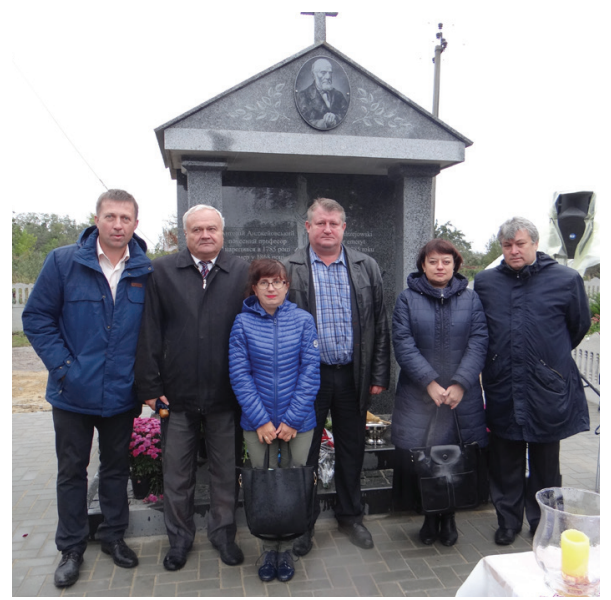

Ботаніки біля меморіалу Антонію Анджейовському в смт Ставище, 29 вересня 2018 р. (зліва направо): В.П. Коломійчук, В.І. Мельник, О.О. Кучер, О.О. Сенчило, Л.В. Зав'ялова, М.В. Шевера. Фото С. Плахотнюка

католицької церкви в Україні отця Марека Рудзя відбулися урочисті заходи 3 нагоди 150-річчя від дня смерті славного ставищанина Антонія Анджейовського. У католицькому кварталі центрального цвинтаря відбулася урочиста меса 3 освячення символічного гробу-меморіалу А. Анджейовському, учасниками якої стали також і автори цього повідомлення. Серед гостей були присутні Консул Республіки Польща пан Бартош Яблонський, дружина Надзвичайного Повноважного Посла Республіки Польща в Україні пані Рената Скурчиньська-Пєкло, ставищенський міський голова Володимир Кошинський, представники різних релігійних конфесій України, діячі громадських і культурних організацій Київської області, науковці 3 Інституту ботаніки ім. М.Г. Холодного НАН України та Національного ботанічного саду ім. М.М. Гришка НАН України, Ботанічного саду ім. акад. О.В. Фоміна Київського національного університету імені Тараса Шевченка.

Авторами пам'ятника, на якому зображено на сьогодні втрачений, оригінальний хрест з могили А. Анджейовського, стали архітектори Петро Пшевлоцький та Олександр Вартилецький 3 


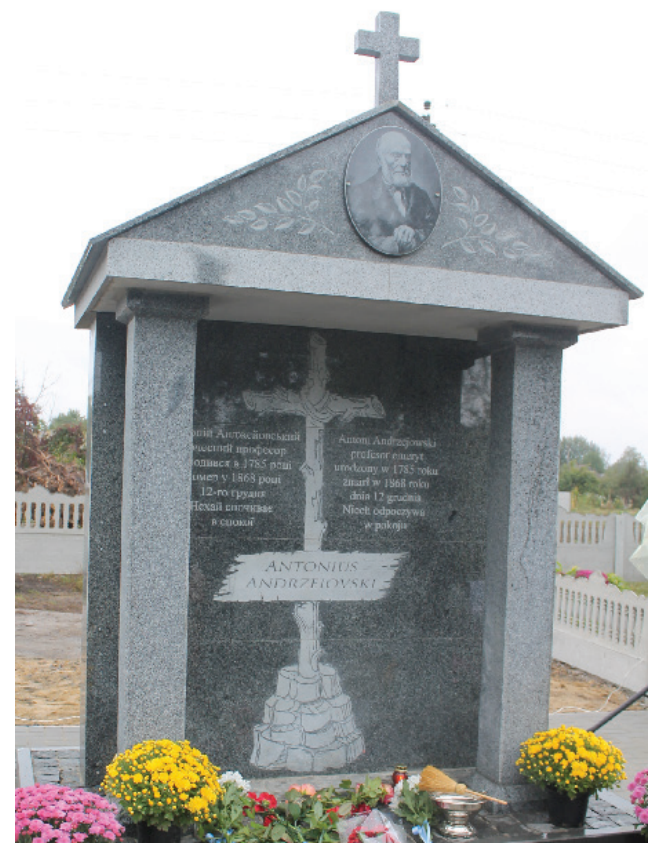

Меморіал Антонію Анджейовському в смт Ставище в день відкриття 29 вересня 2018 р. Фото М. Шевери

м. Богуслав (Київська обл.). Навколо меморіалу стараннями дирекції та співробітників Ботанічного саду ім. О.В. Фоміна було закладено алею із саджанців туй, гінкго та магнолій. Одна 3 алей, що з'явилася після упорядкування цієї ділянки цвинтаря і веде до меморіалу, названа на честь вченого. Тут також планується висадити рослини, що пов'язані з ім'ям вченого (уперше описані або зібрані ним, чи пойменовані на його честь). Серед перших рослин - Spiraea pikoviensis Besser, описаний В. Бессером, але вперше зібраний А. Анджейовським, Senecio borysthenicus Andrz., описаний вченим, і Dianthus andrzejowskianus (Zapał.) Kulcz. - названий на його честь. Рослини згаданих видів ще на початку літа 2018 р. були передані к.б.н. Наталією Белемець (Ботанічний сад ім. О.В Фоміна), к.б.н., доцентом Русланою Мельник (Херсонський державний університет), д.б.н., доцентом Людмилою Любінською (Кам'янець-Подільський національний університет імені Івана Огієнка).

По завершенні меси в місцевому будинку культури учасники зібрання переглянули короткий фільм про вченого, підготовлений завідувачкою відділом обслуговування користувачів Центральної районної бібліотеки Валентиною Пацелею, та взяли участь у науковій конференції, модераторами якої стали отець Марек Рудзь та провідний науковий співробітник Інституту ботаніки ім. М.Г. Холодного НАН України к.б.н., с.н.с. Мирослав Шевера. Загалом було виголошено три наукові доповіді, які перегукувалися за основними етапами та віхами життєвого шляху А. Анджейовського i, разом з тим, висвітлювали й деталізували певні напрями діяльності вченого, окреслюючи його здобутки та результати, цінність яких переосмислено нащадками. Зокрема, завідувач відділу природної флори Національного ботанічного саду ім. М.М. Гришка НАН України д.б.н., професор Віктор Мельник доповів про волинський період життя вченого з акцентом на його ботанічних та інтродукційних дослідженнях. Директор Ботанічного саду ім. акад. О.В. Фоміна (Київський національний університет імені Тараса Шевченка) к.б.н. Олександр Сенчило розкрив внесок вченого в розвиток біологічної освіти, адже саме викладацька діяльність була основною професією А. Анджейовського в Кременці, Києві та Ніжині. Особливої уваги, на думку доповідача, заслуговує висвітлення ролі вченого й педагога в підготовці молодих наукових кадрів та розбудові ботанічного саду, створеного при університеті св. Володимира. Мирослав Шевера у своїй доповіді окреслив основні здобутки вченого в ботанічній, зоологічній, палеонтологічній та геологічній галузях науки.

По завершенні конференції відбувся святковий концерт, підготовлений місцевими народними музичними колективами. Наприкінці урочистостей відбулася презентація книги "Антоній Анджейовський. Талан і таланти відомого натураліста", яку отримали всі учасники заходу. Видання вийшло друком напередодні вшанування пам'яті А. Анджейовського стараннями авторів, видавців та польського мецената пана Кшиштофа Бялого. Усі, хто зацікавиться книгою, можуть ознайомитися 3 нею на електронному ресурсі GoogleBooks (https://books.google.com.ua/ books?id=DoVxDwAAQBAJ).

Захід, що був організований спільними зусиллями духовенства та польської спільноти Ставищенської громади у тісній співпраці з науковцями, має важливе значення для вшанування імені Антонія Анджейовського і надалі матиме продовження. В майбутньому на базі Ботанічного саду ім. акад. О.В. Фоміна Київського національного університету імені Тараса Шевченка, до розбудови якого долучився вчений, планується провести присвячені йому наукові читання.

Л.В. ЗАВ'ЯЛОВА, О.О. СЕНЧИЛО, В.П. КОЛОМІЙЧУК, О.О. КУЧЕР 


\section{Міжнародна науково-практична конференція: "Проблеми збереження гірських екосистем та сталого використання біологічних ресурсів Карпат" (до 50-річчя створення Карпатського біосферного заповідника)}

"Любов до України неможлива без любові до природи", - такими словами Микола Княжицький, голова Комітету з питань культури й духовності Верховної Ради України, народний депутат України, відкрив міжнародну науковопрактичну конференцію "Проблеми збереження гірських екосистем та сталого використання біологічних ресурсів Карпат", яка відбулася 2225 жовтня 2018 р. у Рахові й була присвячена 50-річчю організації Карпатського біосферного заповідника. Доповідач наголосив на тому, що Комітет тісно співпрацює із заповідниками та національними парками, докладаючи зусиль, аби Карпатські проекти отримали підтримку від Євросоюзу, а заповідна справа сприяла розвитку туризму.

До учасників конференції із привітаннями та словами вдячності колективу Карпатського біосферного заповідника звернулись також народний депутат України Іван Рибак, директор Департаменту екологічної мережі та природнозаповідного фонду Мінприроди України Віктор Клід, який оголосив вітання Міністерства екології та природних ресурсів України, голови Рахівської (Павло Басараба) й Тячівської (Іван Фабрицій) районних держадміністрацій, голова Асоціації природоохоронних територій України Микола Стеценко, директор Карпатського біосферного заповідника Микола Рибак та ін.

У роботі конференції взяло участь понад 120 представників науково-дослідних та вищих навчальних закладів, природоохоронних установ, органів влади та громадськості 3 України, Німеччини, Швейцарії, Великобританії, Австрії, Словаччини та Угорщини.

На конференції було розглянуто широке коло питань щодо збереження гірських екосистем та сталого використання біологічних ресурсів в Карпатах, досліджень та моніторингу біотичного й абіотичного середовища, ролі Карпатського біосферного заповідника та інших установ природно-заповідного фонду у вивченні, збереженні

(C) Ф. ГАМОР, 2019 природно-ресурсного потенціалу та впровадженні концепції сталого розвитку. Цим питанням були присвячені доповіді директора Карпатського біосферного заповідника Миколи Рибака ("Карпатський заповідник - крізь призму п'яти десятиріч"), професора університету сталого розвитку із м. Еберсвальде (Німеччина) П'єра Ібіша ("Карпатський біосферний заповідник - рушійна сила транскордонного співробітництва у сфері охорони природи в Центрі Європи"), керівника підрозділу федерального інституту лісових, снігових та ландшафтних досліджень (WSL) із м. Бірменсдорф (Швейцарія) доктора Петера Бранга ("Праліси Угольсько-Широколужанського масиву в умовах кліматичних змін - куди спрямований цей рух?"), наукових співробітників Карпатського біосферного заповідника Василя Покиньчереди та Юрія Беркели ("Основні підсумки міжнародної співпраці Карпатського біосферного заповідника") й Мирослава Кабаля та Дмитра Сухарюка ("Дослідження лісових екосистем Карпатського біосферного заповідника - історія, здобутки та перспективи"). Були також заслухані доповіді словацького професора Івана Волощука ("Історичні аспекти декларації Татранського національного парку (Словаччина) та його управління"), співробітниці Департаменту екологічної мережі та природно-заповідного фонду Мінприроди України Ганни Ковбаснюк ("Аналіз ефективності Конвенції про охорону Всесвітньої культурної і природної спадщини, як міжнародного договору"), професора коледжу університету Рітл (Великобританія) Петера Гобсона ("Сталі рішення в динамічних ландшафтах вимагають стратегій, що базуються на екосистемних підходах"), доктора сільськогосподарських наук iз Українського науково-дослідного інституту гірського лісівництва імені П.С. Пастернака Юрія Шпарика ("Сучасні проблеми гірських лісів Українських Карпат") тощо. Про особливу роль Карпатського біосферного заповідника як рушія процесу номінації букових пралісів Карпат до Всесвітньої спадщини та створення Європейської 


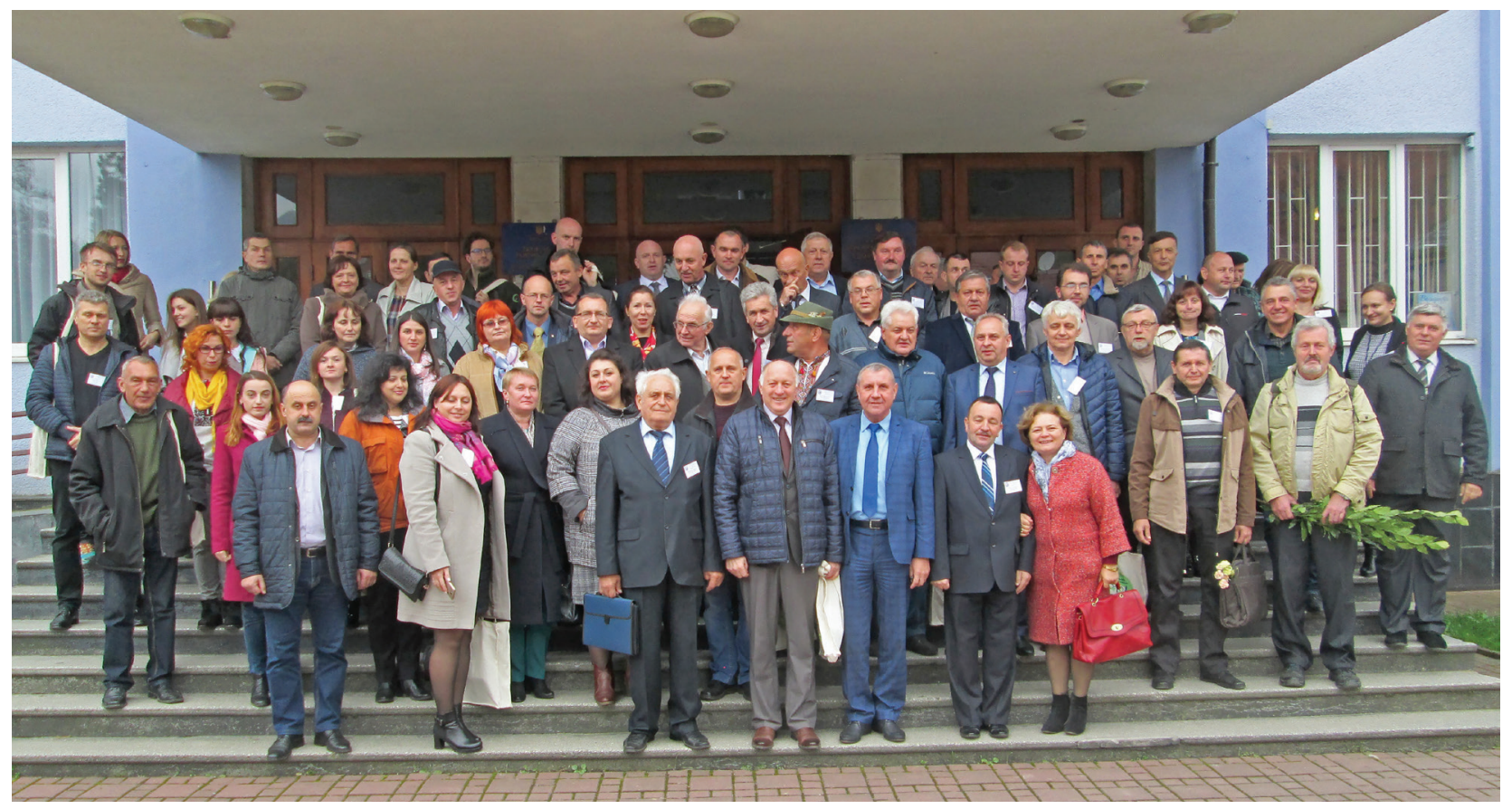

мережі букових лісів доповів професор Ганнес Кнапп (Німеччина).

Представник Впроваджувальної організації українсько-німецького проекту "Підтримка природно-заповідних територій України" Богдан Проць, аналізуючи ефективність менеджменту в Карпатському біосферному заповіднику, відмітив, що заповідник входить до найкращих в Україні, він має найвищий показник ефективності управління, який серед усіх установ природно-заповідного фонду України підвищився на $12 \%$ за період 20072016 pp.

Під час конференції було висловлено чимало цікавих ідей та пропозицій, серед яких слід відмітити виступ Тимура Бедернічека (Національний ботанічний сад ім. М.М. Гришка НАН України) та його співавторів, які запропонували в Карпатському біосферному заповіднику на базі моніторингових ділянок, закладених чеськими професорами Мілошом Дейлом та Алоїсом Златніком на схилах Поп Івана Марамороського майже 90 років тому, створити дослідну станцію з вивчення впливу кліматичних змін на високогірні екосистеми Карпат з наступним включенням іiі до міжнародного проекту GLORIA.

Виступ Федора Гамори - заступника директора Карпатського біосферного заповідника був присвячений історії його створення та розвитку, що бере початок від перших резерватів, які організовувались ще за часів Австро-Угорської імперії. Проблеми 3 організації Карпатського біосферного заповідника в різні часи були пов'язані 3 недосконалістю вітчизняного законодавства, а часом з опором окремих чиновників і частини дезінформованого місцевого населення. У такій ситуації важливу роль відігравав науковий авторитет відомих вчених - українських академіків І.Г. Підоплічка, К.М. Ситника та М.А. Голубця, професорів В.I. Комендаря та С.М. Стойка, чеського професора Алоїса Златніка. Неоціненною була й допомога окремих ентузіастів-однодумців із органів державної влади, територіальних громад та господарських структур. Велика подяка була висловлена управлінцям та господарським керівникам, які відіграли значну роль у створенні та розвитку Карпатського біосферного заповідника в останні 30 років. Завдяки зусиллям багатьох поколінь науковців, урядовців, природоохоронців та любителів природи Карпатський біосферний заповідник збільшився майже в 4 рази й на сьогодні займає площу 58035 га в межах Рахівського, Тячівського, Хустського та Виноградівського районів Закарпатської області. Разом із транзитною зоною площею 124,3 тис. га він входить до Міжнародної мережі біосферних резерватів ЮНЕСКО та репрезентує в ній все ландшафтне 
й біологічне різноманіття Українських Карпат від передгір'я до субальпійської та альпійської зон. Букові праліси Карпатського біосферного заповідника формують найбільшу частину транснаціонального об'єкта Всесвітньої спадщини ЮНЕСКО "Букові праліси й давні ліси Карпат та інших регіонів Свропи".

За 50 років своєї діяльності заповідник отримав міжнародне визнання як природоохоронна, науково-дослідна установа, зробивши вагомий внесок у збереження природних екосистем та сталого розвитку Карпат. Тут створено потужну науково-господарську базу, розбудовано та облаштовано широку мережу інформаційно-туристичної інфраструктури, видається Всеукраїнський екологічний науково-популярний журнал "Зелені Карпати", газета "Вісник Карпатського біосферного заповідника", періодичне видання "Природа Карпат: науковий щорічник Карпатського біосферного заповідника та Інституту екології Карпат НАН України" тощо.
Карпатський біосферний заповідник - єдиний в Україні заповідник, який Радою Європи чотири рази нагороджений Європейським дипломом за природоохоронну діяльність. За оцінкою міжнародних експертів, Карпатський біосферний заповідник є взірцем природоохоронної справи й зберігає еталонні європейські лісові екосистеми.

На конференції презентували монографії автора цього повідомлення, що вийшли друком у 2018 р.: "Еталон європейських лісових екосистем та природоохоронної справи. Про деякі історичні аспекти створення та розвитку Карпатського біосферного заповідника 3 нагоди його 50-річчя" та "Україна-Румунія: мости народної дипломатії. Нотатки з нагоди 20-річчя участі Союзу українців Румунії та Карпатського біосферного заповідника в процесі розвитку українсько-румунської співпраці на Мараморощині". Ці видання містять чимало інформації про роль Карпатського біосферного заповідника у збереженні природи Карпат, реалізації проектів сталого розвитку та міжнародної співпраці.

Ф. ГАMOP 
Рецензія на книгу: Васильева Т.В., Эннан А.А.-А., Шихалеева Г.Н. 2017. Сосудистые растения побережья Куяльницкого лимана, т. 1. Одесса: Освита Украины 336 с.; рис. 23, табл. 7, ил. 481. (Энциклопедия Куяльницкого лимана: В 8-ми томах).

Наприкінці 2017 р. вийшла друком перша книга восьмитомного видання "Энциклопедия Куяльницкого лимана", підготована колективом авторів Фізико-хімічного Інституту захисту оточуючого середовища і людини МОН та НАН України за редакцією професора А.А.-А. Еннана. Куратором видання $є$ Видавнича рада під головуванням Президента НАН України Б.Є. Патона.

Публікація книги, як і самого видання в цілому, є вкрай необхідною і своєчасною в зв'язку 3 катастрофічними екологічними проблемами, що виникли на півдні України, особливо на території Куяльницької мегаекосистеми. Сучасний стан Куяльницького лиману (Одеська обл.) є однією 3 найгостріших екологічних проблем Причорномор'я кінця минулого - початку XXI сторіччя. Він відомий в Україні й поза іiі межами завдяки грязьовому курорту "Куяльник", створеному ще в 1834 р., і мінеральним водам. Стан лиману є вкрай незадовільним. Водна та наземні екосистеми внаслідок зміни клімату, що непомірно посилюється, та антропічного навантаження знаходяться в кризовому стані. Куяльницький лиман швидко втрачає здатність до відновлення ресурсного потенціалу.

Екосистеми Куяльницького лиману, незважаючи на їхню антропічну трансформацію, відзначаються багатством та різноманітністю біоти. Тому, інтегральна оцінка та всебічна характеристика іiі компонентів, зокрема раритетних, рекомендації з охорони та збереження, як і широко висвітлений довідковий матеріал, що будуть представлені у виданні, матимуть велику природоосвітню значущість та використання. Все це стане основою природоохоронної політики в регіоні й оперативного керівництва в справі збереження й невиснажливого диверсифікованого використання

( ) В.В. ПРОТОПОПОВА, П.М. УСТИМЕНКО, 2019 ресурсів. Вони будуть використані при плануванні природоохоронної та господарської діяльності проектованого національного природного парку "Куяльницький", а також для розроблення нормативно-правових документів сталого розвитку Чорноморського регіону.

Перший том під назвою "Судинні рослини Куяльницького лиману" присвячений його флорі, яка нараховує 474 види судинних рослин, що ростуть на схилах та прибережних ділянках Куяльницького лиману. Наводяться відомості 3 їхньої територіальної диференціації, біоморфології, фенології, еколого-ценотичних особливостей та господарської значущості. Надається порівняльний структурний аналіз флори та іiі раритетної фракції, аналізується синантропна компонента.

Робота складається зі змісту, передмови, списку прийнятих скорочень, стислого словника ботанічних термінів і визначень, вступу, п'яти розділів тексту, висновків, закінчення, а також списку літератури, додатків і відомостей про авторів.

У вступі, що анонсує книгу, стисло подано історію лиману, його використання в минулому та нині, відомості про найстаріший в регіоні грязьовий курорт "Куяльницький", надається перелік вчених, які досліджували властивості мінеральних вод, грязей та ропи. Автори підкреслюють недостатнє вивчення флори, аналізують результати ботанічних досліджень, проведених з кінця XIX сторіччя до наших часів. Завершує вступну частину методика досліджень та інформація щодо розташування й пошуку викладеного матеріалу.

Перший розділ книги відкриває фізикогеографічна характеристика території об'єкта досліджень. Подано розташування в системі адміністративного, ботаніко-географічного та геоботанічного районування. Значна увага надається 
характеристиці грунтів, гідрології та гідрохімії власне Куяльницького лиману, висвітлюються питання впливу антропогенних факторів i глобальних змін клімату на трансформацію екосистем. Слід підкреслити, що в результаті власних досліджень авторів виявлено високий рівень хімічного забруднення ропи, пелоїдів, гідробіонтів, грунтів і рослинної сировини. Розділ ілюстрований кольоровими картосхемами території об'єкту досліджень, пунктів розташування джерел забруднення, динаміки зміни площі водної поверхні лиману за останні 10 років. Наводяться оглядові фотографії фрагментів абразивнозсувних ділянок на схилах, ділянок водної ерозії, спустелення та надмірного засолення, а також результати варварського використання ресурсів. Зроблено висновок про посилення негативного впливу на екосистеми лиману, охарактеризовано новітні антропогенні фактори та їхні наслідки.

Другий розділ, головний та найбільший за обсягом, представлений описами видів судинних рослин. У них за єдиним обраним принципом вказані українська, російська й латинська назви, основні морфологічні ознаки, період цвітіння, приналежність до екологічної групи, фітоценотичне приурочення рослин, а також способи розповсюдження діаспор, біоморфа, географія поширення, використання та господарська значущість. Для рідкісних видів вказується ступінь раритетності. Опис кожного виду доповнюється його оригінальною, високоякісною кольоровою фотографією. Українські та російські назви родин і видів наведені відповідно до загальноприйнятої термінології. Розташування відділів представлене за філогенетичною системою А. Енглера, а родини й види - за абеткою.

Третій розділ книги присвячений всебічному аналізу конспекту флори й складається 3 чотирьох взаємопов'язаних підрозділів. Основним $є$ підрозділ 3 аналізу систематичної структури флори, яка налічує 474 види судинних рослин, що належать до 303 родів і 81 родини. Список провідних родин нараховує 320 видів, що складає $67,51 \%$ всієї флори Куяльницької мегаекосистеми, який за співвідношенням показників майже не відрізняється від списків флори Євразійської степової області та ПівнічноЗахідного Причорномор'я. Домінування Asteraceae, Poaceae та Fabaceae підкреслюють високий ступінь синантропізації флори, що характерно для України в цілому, а високе положення Chenopodiaceae - процеси засолення й спустелення. У підрозділі, присвяченому аналізу життєвих форм, автори пов'язують структуру екобіоморф 3 антропогенними трансформаціями, а також цілком аргументовано доводять, що іiі формування відбувалося за високої участі елементів давньосередземноморської флори. Цікаво відзначити, шо в складі флори Куяльницької мегаекосистеми 10,7\% становлять лігнозні форми - дерева та кущі (в Україні 9,9\%), що зумовлено геоморфологічними особливостями території та наслідками надмірної лісомеліорації. Представляють також значний інтерес викладені в цьому підрозділі дані фітоценотичного аналізу й екологічної структури флори. Отримані оригінальні результати підтверджують високе фітоценотичне різноманіття дослідженої території, що представлене зональним (степовим) і азональними (лучним, болотним, вищим водним, галофітним, синантропним) типами організації рослинності. В екологічному спектрі звичайно домінують ксеромезофіти i мезоксерофіти. Завершує розділ созологічна характеристика флори, що представлена 26 видами судинних рослин, серед яких 13 мають різний статус охорони, а 11 включені в Червону книгу України. Велика кількість раритетних видів рослин свідчить про високу фітосозологічну цінність досліджуваної флори та доцільність надання цій території найвищого природоохоронного статусу.

Останні два розділи видання присвячені прикладним питанням, зокрема використанню рослинної сировини в народному господарстві. Надається перелік лікарських, кормових, медоносних, вітаміноносних, декоративних, жироолійних, ефіро-олійних, харчових, дубильних, красильних та харчових рослин. Ці матеріали вкрай важливі для оцінки фіторесурсного потенціалу долини Куяльницького лиману. Значну увагу автори приділяють аналізу наслідків антропогенного впливу на аборигенну фракцію синантропної флори, яка складає $39,5 \%$ всього видового складу. Встановлено переважання видів евапофітів та епекофітів, що свідчить про масштабну трансформацію флори, зокрема в південній частині, та наближення до межі, за якою розпочинаються незворотні деградаційні процеси. Наголошується на необхідності послаблення непомірного антропогенного впливу та проведен- 
ня невідкладних заходів з охорони та збереження, зокрема фіторізноманіття лиману.

У заключенні книги стисло наведені підсумки виконаної роботи, викладено прогноз змін, що відбудуться, та аналітичний огляд ймовірних втрат, у першу чергу фіторізноманіття. Основну частину розділу займає аргументований перелік першочергових заходів з відновлення біотичного потенціалу Куяльницької мегаекосистеми. Намічено шляхи їхньої реалізації та висвітлено реальні заходи, зокрема зі створення природоохоронної установи найвищого рангу - Куяльницького національного природного парку.

У списку використаних літературних посилань наведено 158 найменувань. Алфавітний покажчик назв рослин наведено трьома мовами.

Робота добре ілюстрована рисунками, таблицями, фотографіями видів рослин, їхніх угруповань та рослинного покриву ландшафтів. Всі вони виконані на високому рівні й надають додаткову інформацію про смарагдове багатство Куяльника. Слід також відзначити велику роботу редакційого колективу, зокрема його художнього редактора Г.М. Кірюшкіної.

Достоїнства книги незаперечні, й переважають окремі незначні неточності, які завжди мають місце у виданнях подібного роду.

$€$ очевидним, що книга має велику наукову, науково-освітню та практичну значущість. Вона отримає широке використання в Україні та поза іiі межами, зокрема в країнах, які $\epsilon$ членами міжнародних природоохоронних організацій Чорноморського басейну ("Організації Чорноморського співтовариства" та "Чорноморська синергія" тощо). Викладені в ній матеріали будуть корисними для наукових працівників, аспірантів і студентів, учителів, екологів, біологів, природознавців, екотуристів, а також всіх тих, хто любить і захоплюється природою рідного краю.

В.В. ПРОТОПОПОВА, П.М. УСТИМЕНКО 


\section{ПРАВИЛА ДЛЯ АВТОРІВ "Украӥнського ботанічного журналу"}

«Український ботанічний журнал» публікує оригінальні статті з усіх напрямів ботаніки та мікологіï, а саме: загальних проблем, флористики, геоботаніки, систематики, екології, еволюції, географії, морфології, анатомії, ембріології, фізіології, біохімії, клітинної та молекулярної біології рослин і грибів, історії науки, ботанічного ресурсознавства й охорони фіто та мікобіоти.

Рукописи приймаються українською, англійською та російською мовами (останньою - тільки від авторів 3-поза меж України).

Редакційна колегія «Украӥнського ботанічного журналу» у своїй діяльності дотримується принципів видавничої етики та керується положеннями 3 етики наукових публікацій (Committee on Publication Ethics (COPE) [http://publicationethics.org/], White Paper on Publication Ethics [http://www. councilscienceeditors.org/wp-content/uploads/entire whitepaper.pdf]). Українські автори, серед іншого, мають користуватися «Етичним кодексом ученого України», прийнятим Загальними зборами НАН України 15 квітня 2009 р. (Бюлетень ВАК України, 2010, no 2, c. 2-5).

Автори при поданні рукопису несуть відповідальність за розкриття своїх прямих або непрямих фінансових i інших конфліктних інтересів, здатних вплинути на їхню роботу. У рукописі мають бути згадані всі особи й організації, що надали фінансову підтримку, а також брали у роботі особисту участь. Автори можуть вказувати імена тих, кому, на їхню думку, не слід направляти рукопис на рецензію в зв'язку з можливим, як правило, професійним конфліктом інтересів. Інформацію про наявність конфлікту інтересів редколегія може використовувати як основу для прийняття редакційних рішень.

Фальсифікація та фабрикація даних, плагіат та інші порушення наукової етики є неприпустимими.

Матеріали, подані до друку в інші видання чи вже опубліковані (повністю або частково), не приймаються і не розглядаються. Виключення може бути зроблене лише для оглядових статей, або якщо для поширення наукових знань доцільна публікація в різних журналах чи іншими мовами; в усіх таких випадках потрібні: 1) згода всіх співавторів (якщо вони є); 2) підтверджене погодження редакторів усіх задіяних видань; 3) належні посилання на оригінальні публікації.

При використанні опублікованих в «Українському ботанічному жмрналі» матеріалів посилання на публікацію в «Украӥнському ботанічному журналі» $€$ обов' язковим.

До редколегії на адресу редакції «Українського ботанічного жмурналу» secretary_ubzh@ukr.net окремими файлами потрібно надіслати: $\checkmark$ повний текст статті (з інтегрованими в нього рисунками, таблицями, рефератами) у форматах .doc, .docx або .rtf, $\checkmark$ супровідну інформацію.

Рукописи повинні відповідати стилю та редакційним стандартам «Українського ботанічного жжрнналу». При підготовці рукопису просимо керуватися, крім наведених правил, також останніми номерами журналу та точно дотримуватися їхнього формату.

1. Обсяг тексту (разом зі списком літератури) для проблемно-теоретичних, критичних і дискусійних статей не може перевищувати 25, оригінальних фактологічних - 15, коротких повідомлень, рецензій, хроніки, а також статей із розділів «Ювілейні дати» та «Втрати науки» - 5 стандартних сторінок (див. п. 4). Статті, що $є$ більшими за обсягом, друкуються лише за попереднім узгодженням з редколегією. Рисунки і підписи до них, таблиці та реферати не входять до цього обсягу, але вони не мають перевишувати обсяг текстової частини статті. Таблиці (синоптичні тощо), рисунки (зображення гербарних зразків тощо), додаткові матеріали (список досліджених гербарних зразків, флористичні списки), що займають багато сторінок, можуть бути опубліковані в електронному варіанті журналу як електронні додатки до статті, з посиланням на них у друкованій версії. 
2. Розміщення матеріалу статті: $\checkmark$ назва статті (напівжирним, звичайним за розміром шрифтом); $\checkmark$ ім'я повністю, ініціал по батькові або ініціал другого імені (за потреби) та прізвище автора/ авторів (великими літерами, звичайним за насиченістю шрифтом); $\checkmark$ повна назва установи, де виконане дослідження, її повна поштова адреса, електронні адреси авторів (останні курсивом, без підкреслення); якщо автори працюють у різних установах, цифровим надрядковим індексом пов'язати прізвище автора і місце його роботи; $\checkmark$ реферат і ключові слова англійською мовою; $\checkmark$ реферат та ключові слова українською мовою; $\checkmark$ текст статті; $\checkmark$ список посилань.

3. Структурно стаття має складатися з таких розділів: «Вступ», «Матеріали та методи», «Результати та обговорення» (або «Результати», «Обговорення»), «Висновки», в разі необхідності - «Подяки». В окремих випадках можлива модифікація розділів. Таксономічні, флористичні, проблемнотеоретичні статті та короткі повідомлення можуть бути цілісними, без виділених розділів.

4. Текст статті набирається у текстовому редакторі Word: шрифт Times New Roman; кегль 14; міжрядковий інтервал - 1,5; без переносів i вирівнювання по правому краю; усі поля -2 см; сторінки рукопису позначаються наскрізною нумерацією. Електронний файл рукопису статті повинен мати назву, яка відповідає транслітерації латиницею прізвища першого автора, наприклад, «Petrenko».

Виклад тексту має бути чітким та стислим, без довгих екскурсів і повторень.

Наукові назви таксонів рослин і грибів усіх рангів слід подавати курсивом і лише латинською мовою. При першому їхньому згадуванні в тексті - iз зазначенням авторів таксонів, далі - без авторів, за винятком номенклатурно-таксономічних публікацій (за потреби), а також випадків, коли це слід зробити для уникнення таксономічної неясності чи плутанини. Авторів та ранги таксонів (наприклад, subg., subsp., var. тощо) слід наводити прямим шрифтом. При першому згадуванні видів назва роду подається повністю, надалі скорочується до однієї літери, за винятком тих випадків, коли речення розпочинається з латинської назви або ж коли йдеться про види, що належать до різних родів, назви яких починаються з однакової літери.
У підписах до таблиць та рисунків родові назви рослин та грибів не скорочуються (виключення перелік кількох видів одного роду).

Імена та скорочення імен авторів таксонів рослин слід стандартизувати за «The International Plant Names Index» (http://www.ipni.org/ipni/ authorsearchpage.do), назви та авторів таксонів грибів - за «MусоBank» (http://www.mycobank.org/ quicksearch.aspx). Якщо в назві статті наводяться назви видів (або інших таксонів до родового рангу включно), авторів таксона не вказувати, а в дужках обов'язково вказати родину або таксон вищого рангу, до яких цей вид (види) або інший таксон (інші таксони) належать. Автори таксонів не наводяться i в рефератах. Як виключення, автори таксонів можуть наводитися в назві та/або рефератах лише у номенклатурно-таксономічних статтях і лише тоді, коли ця інформація є критично важливою з номенклатурної точки зору.

Фізичні величини слід наводити в одиницях СI. Для позначення інтервалу значень використовувати коротке тире (n-dash), наприклад: 5-12 см, 6080\%. У тексті повинні бути лише «англійські» лапки. Скорочення слів і словосполучень у тексті статті, в оформленні таблиць і рисунків, окрім загальноприйнятих, неприпустимі. За необхідністю скорочення можна наводити за наявності попереднього розшифрування (наприклад: Національний природний парк (НПП) і далі по тексту - НПП).

У разі морфологічних, анатомічних, палінологічних та інших досліджень слід чітко вказувати кількість використаних рослин, зразків тощо, на основі яких проводили дослідження. Обов'язково цитуються етикетки або інші ідентифікатори використаних гербарних зразків або інших об'єктів зберігання, 3 якими працював автор; якщо зразки чисельні, вказується лише місце зберігання (гербарій, колекція) і номери зразків. Етикетки цитуються повністю, мовою оригіналу із зазначенням (за наявності) номеру зразка або баркоду (штрихкоду, інвентарного номеру) та акроніму гербарію, в якому вони зберігаються; при цитуванні зразків з баз даних гербаріїв адреса (електронна локалізація або електронний ідентифікатор) зображення наводиться за вимогами певного гербарію або бази даних. Акроніми гербаріїв цитуються за «Index Herbariorum» (http://sweetgum.nybg.org/science/ih/) або за виданням «Гербарії України» (2011) (http:// www.botany.kiev.ua/doc/Herbarium_Ukr_2011.pdf). 
Матеріалам щодо першої знахідки виду чи роду рослин і грибів на території України або будьякої іншої країни редакція надає пріоритет. Рішення щодо публікації коротких повідомлень про нову знахідку раніше зареєстрованих таксонів редколегія приймає на свій розсуд, окремо для кожного випадку. Винятком є повідомлення про нові знахідки видів, включених до Червоної книги України.

Літературні джерела слід цитувати у тексті у такий спосіб: П.П. Іваненко (Ivanenko, 2002); (Ivanenko, 2002); (Ivanenko, 2002, 2014a, b; Jones et al., 2004; Petrenko, Sydorova, 2010). В англомовних статтях: Jones (2008), (Jones, 2008) тощо.

Якщо одночасно наводиться декілька посилань, слід дотримуватись хронологічної послідовності. Якщо праця цитується за іiі назвою, цитувати необхідно так: «... до Червоної книги України (Chervona..., 1996, 2009)»; «...в низці праць (Geobotanichne..., 1977; Opredelitel..., 1987, etc.)».

Усі матеріали, які планується оприлюднювати як електронні додатки, необхідно надавати одночасно 3 основним рукописом. Переконайтеся, що ці матеріали згадуються у тексті статті.

Редакція залишає за собою право вносити у текст зміни, які не впливають на зміст, вкладений у нього автором.

5. Таблиці мають бути компактними і наводитися у тексті після першого посилання. Якщо таблиця переходить на наступну сторінку, iї не розбивати, головку не дублювати. Якщо таблиця займає більше сторінки, іiі необхідно надіслати також в електронному варіанті окремим файлом, наприклад, «Petrenko_Tab04» (у разі, якщо стаття прийнята до друку). Головки таблиць повинні точно відповідати змісту граф. Матеріал, наведений у таблицях, не повинен дублюватися в тексті, але може бути частково використаний при обговоренні результатів. Назва кожної таблиці наводиться мовою статті (якщо стаття не англійською мовою) та англійською, назви родів (якщо є) не скорочуються. Таблиці в електронному додатку (за наявності) нумерувати незалежно від таблиць у тексті і позначати з додаванням літери Е: Таблиця Е1. тощо.

Усі умовні позначки та скорочення повинні бути розшифровані у виносках таблиці, навіть якщо вони також розшифровані в тексті (проте, якщо вони використовуються в наступних таблицях, можна зробити це лише у першій таблиці).

6. Ілюстрації автор розмішує в тексті статті після першого посилання на них (розмір усього файлу статті з рисунками в редакторі Word не повинен перевищувати 15 Мбайт). На кожний рисунок необхідні посилання в тексті статті. Матеріал, наведений на рисунках, не має дублюватися в тексті. Однотипні рисунки та діаграми повинні бути витримані в однаковій стилістиці. Кожна вісь повинна бути позначена та мати одиниці вимірювання; товщина ліній не повинна бути меншою за 1 пт.

У разі, якщо стаття прийнята до друку, кожну ілюстрацію також потрібно надіслати окремим повнорозмірним електронним файлом у форматі програми, з якою працювали автори (Statistica, Adobe Photoshop, Excel тощо) з назвою файлу «Petrenko_ Fig01», «Petrenko_Fig02» тощо. Ілюстрації мають бути чіткими та контрастними, 3 роздільною здатністю щонайменше $\mathbf{3 0 0}$ пікселів на дюйм. Зображення у форматі .jpeg (.jpg) слід зберігати в режимі «максимальний». Якщо фото зібрані в таблицю, зображення позначати зліва направо і згори донизу великими прямими латинськими літерами.

Кожна ілюстрація супроводжується підписами українською (якщо стаття не англійською мовою) та англійською, наприклад:

Рис. 1. Cannabis ruderalis. А: жіноча квітка; В: чоловіча квітка

Fig. 1. Cannabis ruderalis. A: pistillate flower; B: staminate flower

У підписах слід пояснювати значення всіх умовних позначок; до мікрофотографій потрібно вказувати збільшення (у вигляді текстового пояснення та/ або добре помітного масштабного штриха або масштабної лінійки), назви родів не скорочувати.

Рисунки в електронному додатку (за наявності) нумерувати незалежно від рисунків у тексті і позначати з додаванням літери Е: Рис. Е1. тощо. Усі умовні позначки та скорочення повинні бути розшифровані, навіть якщо вони також розшифровані в тексті (проте, якщо вони використовуються в наступних рисунках, можна зробити це лише у підпису до першого). 
7. Список посилань має містити лише процитовані джерела і складатися за латинською абеткою. Публікації одного автора (або групи тих же авторів) розмішуються в хронологічній послідовності. Якщо протягом року опубліковано декілька праць, вони позначаються відповідно літерами a, b, с тощо; ці літери вказуються поряд із роком публікації (1970а, 1985b тощо). Якщо цитується не перше видання певної праці, це потрібно зазначити (4 вид., $4^{\text {th }}$ ed. тощо). У посиланнях слід наводити всіх авторів роботи, незалежно від їхньої кількості (за винятком спільного авторства консорціумів, наприклад, Angiosperm Phylogeny Group - APG, тощо). При посиланнях на «Флори», «Червоні книги» тощо, цитування починати 3 автора/авторів обробки певного таксона або таксонів, що розглядаються.

Праці, опубліковані латиницею, подаються мовою оригіналу. Для праць, опублікованих кирилицею, необхідно подавати транслітерований або перекладений латиницею бібліографічний опис. Транслітератор, якимобов'язковослідкористуватися, розміщений на сайті «Українського ботанічного журналу»: http://ukrbotj.co.ua/tools. Зверніть увагу: транслітерація посилань українською і російською мовами відрізняється. Прізвища авторів транслітеруються так, як вони наводяться самими авторами (потрібно орієнтуватися на англомовні реферати нещодавно опублікованих праць цих авторів; для номенклатурно-таксономічних робіт - також на стандартну латинізовану форму прізвища). Якщо праця (книга, автореферат, збірка матеріалів конференціі) опублікована, наприклад, українською мовою, але має також оригінальну назву англійською, латинською тощо (наведену на титульному аркуші книги або в рефераті), то варто навести їі замість транслітерованої.

У разі потреби неопубліковані дані можуть надаватися лише у тексті статті 3 приміткою «персональне повідомлення», тільки за згодою особи, що надала інформацію і з позначенням цієї особи. Цитування дисертаційних робіт і звітів у списку посилань надавати з позначкою «рукопис», «manuscript».

\section{Список посилань оформлювати за наведеними зразками}

\section{Книги}

Zerov D.K. 1964. Flora pechinochnykh i sfahnovykh mokhiv Ukrainy. Ed. A.M. Oxner. Kyiv: Naukova Dumka, 357 pp. [Зеров Д.К. 1964. Флора печіночних і сфагнових мохів України. Відп. ред. А.М. Окснер. Київ: Наукова думка, 357 с.].

Dudka I.O, Heluta V.P., Tykhonenko Yu.Ya., Andrianova T.V., Hayova V.P., Prydiuk M.P., Dzhagan V.V., Isikov V.P. 2004. Hryby pryrodnykh zon Krymu (Fungi of the Crimean Peninsula). Ed. I.O. Dudka. Kyiv: Phytosociocentre, 452 рр. [Дудка I.О., Гелюта В.П., Тихоненко Ю.Я., Андріанова Т.В., Гайова В.П., Придюк М.П., Джаган В.В., Ісіков В.П. 2004. Гриби природних зон Криму. Ред. І.О. Дудка. Київ: Фітосоціоцентр, 452 с.].

Wettstein R. 1935. Handbuch der Systematischen Botanik. Leipzig; Wien: Franz Deutike, 994 S.

\section{Окрема книга з багатотомного видання}

Didukh Ya.P., Korotchenko I.A., Fitsailo T.V., Burda R.I., Moysiyenko I.I., Pashkevich N.A., Iakushenko D.M., Shevera M.V.2010. Ekoflora Ukrainy(Ekoflora of Ukraine), vol. 6. Ed. Ya.P. Didukh. Kyiv: Phytosociocentre, 422 pp. [Дідух Я.П., Коротченко І.А., Фіцайло Т.В., Бурда P.I., Мойсієнко I.I., Пашкевич Н.А., Якушенко Д.М., Шевера М.В. 2010. Екофлора України, т. 6. Відпов. ред. Я.П. Дідух. Київ: Фітосоціоцентр, $422 \mathrm{c.}$.].

Neyburg M.F. 1948. Verkhnepaleozoyskaya flora Kuznetskogo basseyna. In: Paleontologiya SSSR, vol. 12, part 3, issue 2. Moscow; Leningrad: Izdvo AN SSSR, 418 pp. [Нейбург М.Ф. 1948. Верхнепалеозойская флора Кузнеикого бассейна. В кн.: Палеонтология СССР, т. 12, ч. 3, вып. 2. Москва; Ленинград: Издво АН СССР, 418 с.].

\section{Частина книги}

Protopopova V.V. 2009. Dactylorhiza cordigera. In: Chervona knyha Ukrainy. Roslynnyi svit (Red Data Book of Ukraine. Plant Kingdom). Ed. Ya.P. Didukh. Kyiv: Globalconsulting, p. 565. [Протопопова В.В. 2009. Dactylorhiza cordigera. В кн.: Червона книга Украӥни. Рослинний світ. Ред. Я.П. Дідух. Київ: Глобалконсалтинг, с. 565].

Gymez A., Lunt D.H. 2006. Refugia within refugia: patterns of phylogeographic concordance in the Iberian Peninsula. In: Phylogeography of Southern European Refugia. Eds S. Weiss, N. Ferrand. Dordrect: Springer, pp. 155-188.

\section{Періодичні видання}

Mosyakin S.L. 2018. The correct name in Knowltonia for an iconic southern African species earlier known as Anemone tenuifolia and A. capensis (Ranunculaceae). Ukrainian Botanical Journal, 75(3): 230-237. https:// doi.org/10.15407/ukrbotj75.03.230 
Mosyakin S.L. 2002. Ukrainian Botanical Journal, 59(6): 696-701. [Мосякін С.Л. 2002. Система та фітогеографія Chenopodium L. subgen. Blitum (L.) I. Hiitonen (Chenopodiaceae). Український ботанічний журнал, 59(6): 696-701].

Didukh Ya.P., Alioshkina U.M. 2007. Ukrainian Phytosociological Collection, Series C. Phytoecology, 25: 4-17. [Дідух Я.П., Альошкіна У.М. 2007. Оцінка енергетичного балансу екосистем Києва та його зеленої зони. Український фітоценологічний збірник, Серія С. Фітоекологія, 25: 4-17].

\section{Дисертації / Автореферати дисертацій}

Prydiuk M.P. 2018. Mushrooms of the families Bolbitiaceae and Psathyrellaceae of Ukraine: species composition, distribution, evolution: Dr. Sci. Diss. Kyiv, M.G. Kholodny Institute of Botany NAS of Ukraine, 368 pp. (manuscript). [Придюк М.П. 2018. Гриби родин Bolbitiaceaema та Psathyrellaceae України: видовий склад, поширення, еволюція: дис. ... д-ра. біол. наук: спец. 03.00.21 «Мікологія». Київ, Інститут ботаніки ім. М.Г.Холодного НАН України, 368 с. (рукопис)].

Kucher O.O. 2016. The alien fraction of the flora of the Starobilsk Grass-meadow Steppe and its invasive potential: Cand. Sci. Diss. Abstract. Kyiv, M.G. Kholodny Institute of Botany NAS of Ukraine, 18 pp. [Кучер O.O. 2016. Адвентивна фракція флори Старобільського злаково-лучного степу та iii інвазійний потенціал: автореф. дис. ... канд. біол. наук: спец. 03.00.05 «Ботаніка». Київ, Інститут ботаніки ім. М.Г.Холодного НАН України, 18 с.].

\section{Електронні ресурси}

IPNI. The International Plant Names Index. 2012-onward. Available at: http://www.ipni.org (Accessed 21 March 2019).

Посилання можна наводити безпосередньо в тексті (особливо за відсутності автора публікаціі)як http адресу, наприклад: «...назви видів наведено за http://www.tropicos.org/ та за http://www. indexfungorum.org/Names/Names.asp»

\section{Матеріали конференцій, семінарів}

Davydov D.A. 2018. In: Classification of vegetation and biotopes of Ukraine: the Third Ukrainian Scientifictheoretical Conference proceedings. Eds Ya.P. Didukh, D.V. Dubyna. Kyiv, pp. 124-129. [Давидов Д.А. 2018. Фітосоціологічна номенклатура в Україні: сучасний стан та перспективи подальшого розвитку. В зб.: Класифікація рослинності та біотопів України: матеріали третьої науково-теоретичної конференціі (Київ, 19-21 квітня 2018 р.). Ред.: Я.П. Дідух, Д.В. Дубина. Київ, с. 124-129].

8. Реферати оформлювати таким чином: $\checkmark$ прізвище й ініціали автора/авторів; $\checkmark$ назва статті (напівжирним шрифтом); $\checkmark$ повна назва установи, де виконане дослідження, iii повна поштова адреса; якщо автори працюють у різних установах, цифровим надрядковим індексом пов'язати прізвище автора і місце його роботи (якщо стаття українською мовою, ці дані надавати лише в англомовному рефераті, якщо - англійською, тільки в україномовному); $\checkmark$ текст реферату; $\checkmark$ ключові слова. $\checkmark$ посилання на додаткові матеріали (електронний додаток) за необхідності.

Текст реферату (не менше 1800 знаків) повинен мати чітку структуру, бути змістовним, інформативним, логічно вибудуваним, тобто давати повне уявлення про роботу; слід уникати скорочень (крім загальноприйнятих) та посилань.

Ключові слова (не більше восьми) наводяться в абетковій послідовності кожної з мов, друкуються прямим шрифтом, латинські назви - курсивом, відокремлюються комами. Бажано уникати повторення слів із назви статті.

\section{9. Супровідна інформація.}

На окремому аркуші (окремим файлом «Petrenko Info») обов'язково надаються відомості про всіх авторів статті: $\checkmark$ прізвище, ім'я та по батькові повністю українською та англійською мовами (окремо позначається автор, який листуватиметься 3 редакцією); $\checkmark$ науковий ступінь і посада; $\checkmark$ контактні номери телефонів; $\checkmark$ адреси електронної пошти.

До статей аспірантів обов'язкова рекомендація наукового керівника.

10. Праці, в яких описуються нові таксони, повинні містити інформацію про гербарій, до якого здано на зберігання голотипи цих таксонів. Ізотипи передаються до Національного гербарію України (гербарію Інституту ботаніки імені М.Г. Холодного НАН України - KW). При повідомленні про флористичні знахідки у статті необхідно вказати, у гербарії якої наукової установи зберігаються гербарні зразки, а також, за наявності, надати їхні унікальні ідентифікатори (наприклад, номери зборів того чи іншого колектора або баркод, інвентарний номер гербарію або інший цифровий ідентифікатор).

11. Реєстрація цифрового ідентифікатору об'єкту (DOI) для статей, що публікуються в «Українському ботанічному журналі», $€$ платною і складає близько 3 ум. од. за статтю. Умови сплати редакція повідомляє авторам після прийняття статті до друку. 
Статті, оформлення яких не відповідає правилам, не приймаються і не розглядаються.

Подані рукописи підлягають односторонньому «сліпому» рецензуванню (single-blind review) двома рецензентами та науковому редагуванню.

Редколегія залишає за собою право беззаперечно відхиляти статті на основі негативних анонімних або відкритих рецензій чи експертних висновків членів редколегії або інших фахівців.
Автори зобов'язані надавати обгрунтовані та аргументовані відповіді на зауваження рецензентів та наукового редактора.

Після повернення авторами остаточної верстки зміни до тексту не приймаються.

Правила для авторів в електронному вигляді доступні на http://ukrbotj.co.ua/authors 
Український ботанічний журнал, т. 76, № 1, 2019. Національна академія наук України. Інститут ботаніки ім. М.Г. Холодного. Науковий журнал. Заснований у 1921 р. Виходить один раз на два місяці (українською, англійською та російською мовами). Головний редактор С.Л. Мосякін

Затверджено до друку вченою радою Інституту ботаніки ім. М.Г. Холодного НАН України (протокол № 3 від 12 березня 2019 року)

Реєстраційне свідоцтво серії КВ № 12179-1063ПР від 11.01.2007 р.

Редактор О.В. Пилипенко

Технічний редактор О.С. Бондаренко

Комп'ютерна верстка Д.С. Решетников

Формат 84×108/16. Ум.-друк. арк. 9,0. Обл.-вид. арк. 11,5. Тираж 176 прим. Зам. №

Віддруковано ВД "Академперіодика" НАН України

вул. Терещенківська, 4, Київ 01004

Свідоцтво суб’єкта видавничої справи ДК № 544 від 27.07.2001 
